\title{
A House I de Peter Eisenman, entre as bases formais da arquitetura e a arquitetura conceitual
}

Versão Corrigida

EXEMPLAR REVISADO E ALTERADO EM RELAÇÃO À VERSÃO ORIGINAL, SOB RESPONSABILIDADE DO(A) AUTOR(A) E ANUÊNCIA DO(A) ORIENTADOR(A). A versão original, em formato digital, ficará arquivada na biblioteca da faculdade.

São Paulo, 01 de Junho de 2020.

Dissertação apresentada à Faculdade de Arquitetura e Urbanismo da Universidade de São Paulo para a obtenção do título de Mestre em Arquitetura e Urbanismo.

Área de concentração: História e Fundamentos da Arquitetura e do Urbanismo

Orientador: Prof. Dr. José Tavares Correia de Lira 
Autorizo a reprodução e divulgação total ou parcial deste trabalho, por qualquer meio convencional ou eletrônico, para fins de estudo e pesquisa, desde que citada a fonte.

E-mail do autor: bruno.mentone.arq@gmail.com

Catalogação na Publicação

Serviço Técnico de Biblioteca

Faculdade de Arquitetura e Urbanismo da Universidade de São Paulo

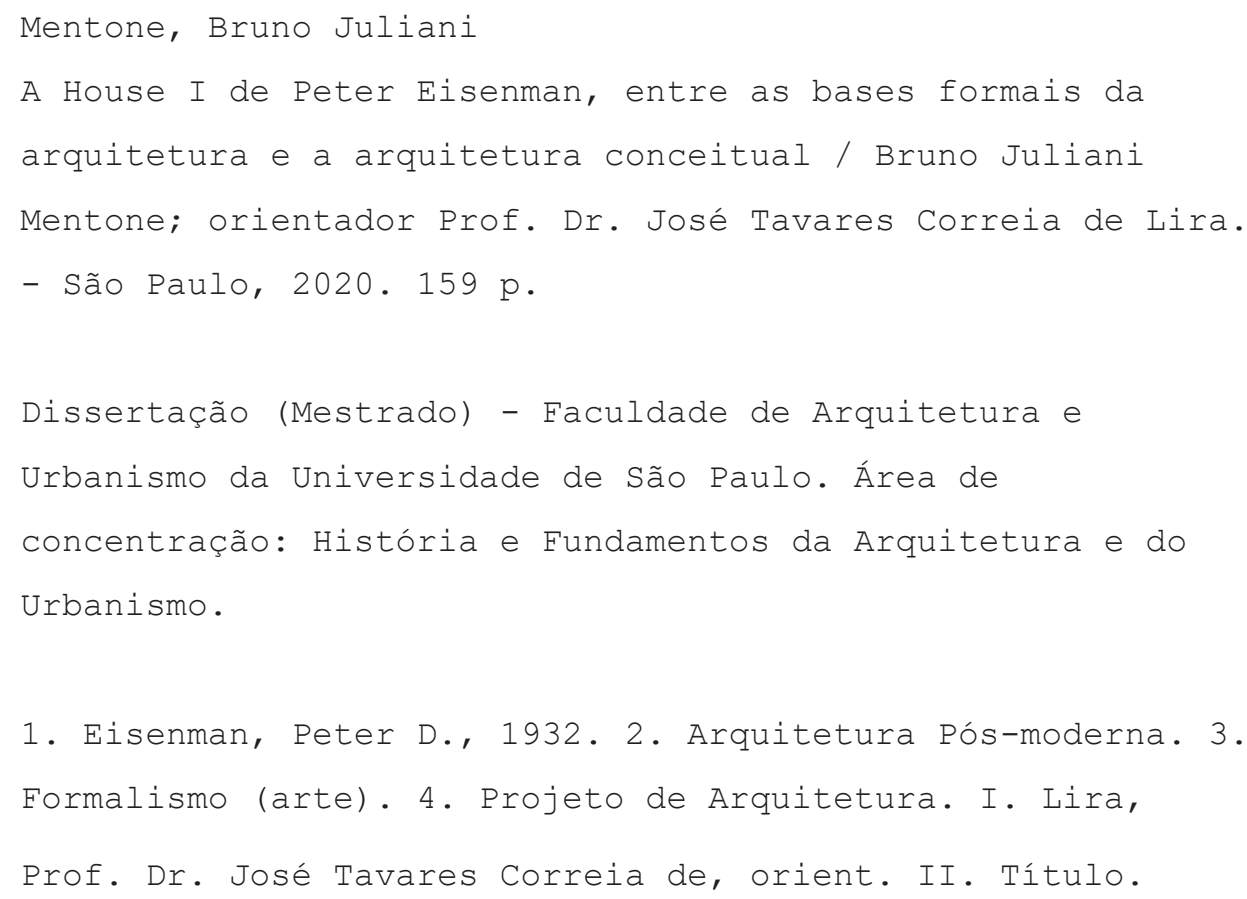

Elaborada eletronicamente através do formulário disponível em: <http://www.fau.usp.br/fichacatalografica/> 
Nome: MENTONE, Bruno Juliani

Título: A House I de Peter Eisenman, entre as bases formais da arquitetura e a arquitetura conceitual.

Dissertação apresentada à Faculdade de Arquitetura e Urbanismo da Universidade de São Paulo para a obtenção do título de Mestre em Arquitetura e Urbanismo. Área de concentração: História e Fundamentos da Arquitetura e do Urbanismo.

Aprovado em: $\quad / \quad /$

\section{BANCA EXAMINADORA}

Prof. Dr.

Instituição:

Julgamento:

Assinatura:

Prof. Dr.

Instituição:

Julgamento:

Assinatura:

Prof. Dr.

Instituição:

Julgamento:

Assinatura: 
U

$\bigcirc$

皆

[I]

$\Omega$

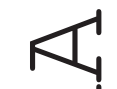

م

U

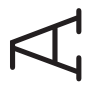


Agradeço ao meu orientador, Prof. Dr. José Tavares Correia de Lira, pelas diversas contribuições para a minha formaçáo como arquiteto e pesquisador, participando de meu trajeto desde a graduação, orientando meu trabalho final de graduação e agora esta dissertação de mestrado. Sou grato pelo incentivo, por ter acreditado na viabilidade deste empenho mesmo em momentos nos quais tive dúvidas.

Aos professores membros da Banca de Qualificação: Prof. Dr. Mário Henrique D’Agostino, pelas observaçóes minuciosas, pelo empenho em ler e discutir o trabalho e por me propiciar compreender melhor os caminhos da pesquisa; e ao Prof. Dr. Rafael Urano Frajndlich, cujos comentários foram decisivos ao caminho tomado pela pesquisa, pelas conversas sobre o que é fazer pesquisa e pelos incentivos, pelo fôlego que me proporcionou para desenvolver este trabalho.

Aos docentes das disciplinas cursadas durante o mestrado, cujas discussóes contribuíram para a dissertação e para a minha formação: Prof. Dr. Guilherme Teixeira Wisnik; Prof. Dr. Wagner Souza e Silva; Prof. Dr. Eugênio Bucci; e Prof. Dr. Vladimir Safatle.

Agradeço aos amigos e colegas de pesquisa com os quais compartilhei disciplinas, cujos encontros semanais, por seis meses ou um ano, fomentaram importantes discussôes, especialmente Carolina Boaventura, Jaime Solares, Karen Matsuda e Margot Pavan; e a Adriano Tao, Bárbara Scheid e Vitor Araujo, que, junto aos primeiros, são amigos que me preporcionaram conversas das mais variadas, seja sobre o tema, seja sobre desabafos e dúvidas acerca do processo, ou sobre a vida em geral.

Aos meus pais, Shirlei Maria Juliani Mentone e Luiz José Mentone, pela paciência e pelo incentivo nesta trajetória. Aos meus irmãos Kelly, Ivan e Gabriel e ao meu sobrinho João Gabriel, pelo apoio, pelos momentos de distração e pela compreensão de minhas ausências e humores.

À Tamiris de Moraes, minha companheira, minha parceira, que me suportou nos diferentes sentidos desta palavra ao longo deste percurso. Sou grato pelos momentos nos quais me incentivou, pelos momentos que relevou e também por aqueles que me censurou, permitindo que eu perseverasse, que eu respirasse e que eu crescesse. 


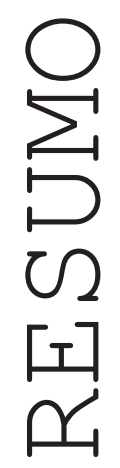


Peter Eisenman é um importante arquiteto contemporâneo. Atuando desde a década de 1960, é considerado como um dos principais nomes do chamado pós-modernismo e da arquitetura desconstrutivista, reconhecido por sua postura crítica à disciplina e por sua exploração da forma e de suas possibilidades de sentido. Esta pesquisa visa a retomar o período inicial de seu percurso, no qual procura aquilo que é próprio da arquitetura, o que não é contaminado por fatores que denomina de externos à disciplina, busca formas com sentido menos determinado, uma arquitetura autônoma. Para tal, retoma o início de sua atuação, sua tese de Ph.D defendida em 1963 - The Formal Basis of Modern Architecture -, texto de pouca circulação até 2006, quando Eisenman publica fac-símile. A ausência deste texto consolidou o início da década de 1970, com projetos da House I e da House II, expostos no livro Five Architects, e textos como Dall'Oggetto alla Relazionalità: la Casa del Fascio di Terragni e Notes on Conceptual Architecture como suas primeiras exploraçóes. Há diferenças entre esses dois momentos. Em sua Tese, compreende a forma como campo próprio da arquitetura, mas indissociável do dia a dia, ela participa do que denomina de ordem total junto de outros elementos como função e técnica. No início da década de 1970, encontra autonomia da forma em relação a outros elementos a partir dos conceitos de estrutura profunda e estrutura aparente. A leitura desses dois momentos permitirá a identificação de processo utilizado por Eisenman. Essa divisão de um elemento, ordem total, em dois, estrutura profunda e aparente, marca importante ferramenta de Eisenman: a desestabilização de elementos por meio de sua quebra em pares cujos termos são irredutíveis uns aos outros, condição que denominará de dialética ou ambiguidade. A partir destas consideraçóes, analisaremos a House I por dois pontos de vista. Primeiro retomando a leitura sedimentada por Eisenman no livro Five Architects, no qual este projeto é alinhado à leitura que faz da House II, marcado como início de conjunto de casas que desenvolve durante a década de 1970. Em seguida, desenvolveremos a leitura da House I a partir do modo como analisa projetos em sua Tese. A contraposição destas duas faces da House I - uma dela adiante, outra dela para trás permitirá a identificação da House I como ponto de inflexão, relacionando-a à carreira de Eisenman. Assim, encontramos características que abandona, outras que são paulatinamente desenvolvidas em projetos seguintes e as que são suspensas e retomadas anos adiante, além de lançarmos luz sobre as discussôes de Eisenman sobre a forma e a autonomia da arquitetura.

Palavras-chave: Eisenman, Peter D., 1932. Arquitetura pós-moderna. Formalismo (Arte). Projeto de Arquitetura. 


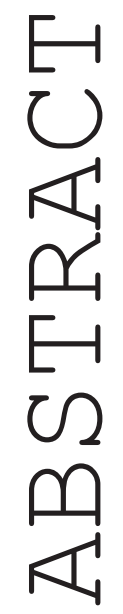


Peter Eisenman is an important contemporary architect. Acting since the 1960s, he is considered as one of the main names of the so-called postmodernism and deconstructivist architecture, recognized for his critical stance towards the discipline and for his exploration of form and its possibilities of meaning. This research aims to retake the initial period of his career in which he seeks what is architecture itself, what is not contaminated by factors that he calls external to the discipline, search forms with less determined meaning, an autonomous architecture. For this, retakes the beginning of his career, his Ph.D. Thesis defended in 1963, - The Formal Basis of Modern Architecture -, text with little circulation until 2006, when Eisenman publishes facsimile. The absence of this text consolidated the early 1970s, with projects as House I and House II, as exposed in the book Five Architects, and texts such as Dall'Oggetto alla Relazionalità: la Casa del Fascio di Terragni and Notes on Conceptual Architecture as his first explorations. There are differences between these two moments. In his Thesis, he understands form as the proper field of architecture, but inseparable from day-today life, it participates in what he calls the total order together with other elements such as function and technique. In the early 1970s, he found form autonomy in relation to other elements based on the concepts of deep structure and apparent structure. Reading these two moments will allow the identification of a process used by Eisenman. This division of one element, total order, in two, deep and apparent structure, marks an important tool of Eisenman: the destabilization of elements by breaking them into pairs whose terms are irreducible to each other, condition that he will call dialectic or ambiguity. From these considerations we will analyze House I from two points of view. First resuming the reading sedimented by Eisenman in the book Five Architects, in which this project is aligned with the reading he makes of House II, marked as the beginning of a set of houses that he developed during the 1970s. Then we will develop a reading of House I from the way he analyzes projects in his Thesis. The opposing of these two faces of House I - one from it ahead and another from it to behind - will allow the identification of House $I$ as an inflection point, relating it to Eisenman's career. Finding characteristics that he abandoned, others that are gradually developed in subsequent projects and others that are suspended and resumed years later, besides shedding light on Eisenman's discussions on the form and autonomy of architecture.

Keywords: Eisenman, Peter D., 1932. Post Modern Architecture. Formalism (art). Architecture Project. 
U

[T]

U

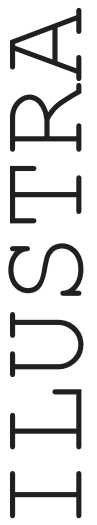

[기

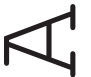

E

$\Omega$

$\mapsto$

$\mapsto$ 


\section{Capítulo 01}

Figura 01: Sequência de transformaçóes do projeto da House IV. Fonte: Site Museum of Modern Art (MoMA), disponível em https://www.moma.org/collection/works/799. Acesso 31/01/2020.

Figura 02: House I. Fonte: Site Eisenman Architects, disponível em https:/eisenmanarchitects.com/ House-I-1968. Acesso 31/01/2020.

Figura 03: House II. Fonte: Site Eisenman Architects, disponível em https://eisenmanarchitects.com/HouseII-1970. Acesso 31/01/2020.

Figura 04: House III. Fonte: Site Eisenman Architects, disponível em https://eisenmanarchitects.com/ House-III-1971. Acesso 31/01/2020.

Figura 05: Maquete House IV. Fonte: Site Eisenman Architects, disponível em https://eisenmanarchitects. com/House-IV-1971. Acesso 31/01/2020.

Figura 06: House VI. Fonte: Site Eisenman Architects, disponível em https:/eisenmanarchitects.com/ House-VI-1975. Acesso 31/01/2020.

Figura 07: Maquete House X. Fonte: Site Eisenman Architects, disponível em https://eisenmanarchitects. com/House-VI-1975. Acesso 31/01/2020.

Figura 08: Maquete House XIa no Cannaregio. Fonte: Site Eisenman Architects, disponível em https:// eisenmanarchitects.com/Cannaregio-Town-Square-1978. Acesso 31/01/2020.

Figura 09: Maquete Cannaregio. Fonte: Site Eisenman Architects, disponível em https://eisenmanarchitects. com/Cannaregio-Town-Square-1978. Acesso 31/01/2020.

Figura 10: Desenhos conceituais IBA Social Housing. Fonte: Site Eisenman Architects, disponível em https://eisenmanarchitects.com/IBA-Social-Housing-1985. Acesso 31/01/2020.

Figura 11: Perspectiva Wexner Center. Fonte: Site Eisenman Architects, disponível em https:// eisenmanarchitects.com/Wexner-Center-for-the-Visual-Arts-and-Fine-Arts-Library-1989. Acesso $31 / 01 / 2020$.

Figura 12: Maquete La Villette. Fonte: Site Eisenman Architects, disponível em https://eisenmanarchitects. com/La-Villette-1987. Acesso 31/01/2020.

Figura 13: Maquete Guardiola House. Fonte: Site Eisenman Architects, disponível em https:// eisenmanarchitects.com/Guardiola-House-1988. Acesso 31/01/2020.

Figura 14: Maquete Aronoff Center for Design and Arts. Fonte: Site Eisenman Architects, disponível em https://eisenmanarchitects.com/Aronoff-Center-for-Design-and-Art-1996. Acesso 31/01/2020.

Figura 15: Maquete Max Reinhardt Haus. Fonte: Site Eisenman Architects, disponível em https:// eisenmanarchitects.com/The-Max-Reinhardt-Haus-1992. Acesso 31/01/2020.

Figura 16: Maquete Cidade da Cultura. Fonte: Site Eisenman Architects, disponível em https:// 
eisenmanarchitects.com/City-of-Culture-of-Galicia-2011. Acesso 31/01/2020.

Figura 17: Memorial aos Judeus Assassinados da Europa. Fonte: Site Eisenman Architects, disponível em https://eisenmanarchitects.com/Berlin-Memorial-to-the-Murdered-Jews-of-Europe-2005. Acesso $31 / 01 / 2020$.

Figura 18: Representação do Memorial Square World Trade Center. Fonte: Site Eisenman Architects, disponível em https://eisenmanarchitects.com/Memorial-Square-World-Trade-Center-2002. Acesso $31 / 01 / 2020$.

Figura 19: Perspectivas isométricas conceituais da House I apresentadas no livro Five Architects. Fonte: EISENMAN, Peter et al. Five Architects: Eisenman, Graves, Gwathmey, Hejduk, Meier. Oxford University Press, 1975. p.22.

Figura 20: Perspectivas isométricas conceituais da House II apresentadas no livro Five Architects. Fonte: EISENMAN, Peter et al. Five Architects: Eisenman, Graves, Gwathmey, Hejduk, Meier. Oxford University Press, 1975. p.32-35.

\section{Capítulo 02}

Figura 21: Situação do Pavilhão Suíço. Fonte: EISENMAN, Peter. The Formal Basis of Modern Architecture. Zurich: Lars Müller Publishers, 2006c, p.148.

Figura 22: Deformaçôes da parede do fundo e balcão de recepção. Fonte: EISENMAN, Peter. The Formal Basis of Modern Architecture. Zurich: Lars Müller Publishers, 2006c, p.152-154.

Figura 23: Deformaçōes comparadas ao volume não deformado. Fonte: EISENMAN, Peter. The Formal Basis of Modern Architecture. Zurich: Lars Müller Publishers, 2006c, p.159.

Figura 24: Sequências de fechamento. Fonte: EISENMAN, Peter. The Formal Basis of Modern Architecture. Zurich: Lars Müller Publishers, 2006c, p.166.

Figura 25: Articulação do eixo interno e eixo externo e sistema de movimento. Fonte: EISENMAN, Peter. The Formal Basis of Modern Architecture. Zurich: Lars Müller Publishers, 2006c, p.172.

Figura 26: Plano de Referência. Fonte: EISENMAN, Peter. The Formal Basis of Modern Architecture. Zurich: Lars Müller Publishers, 2006c, p.168.

Figura 27: Sistema de movimento no acesso. Fonte: EISENMAN, Peter. The Formal Basis of Modern Architecture. Zurich: Lars Müller Publishers, 2006c, p.174.

Figura 28: Dialética massa-superfície. Fonte: EISENMAN, Peter. The Formal Basis of Modern Architecture. Zurich: Lars Müller Publishers, 2006c, p.178.

Figura 29: Fechamento da forma em planta e elevação. Fonte: EISENMAN, Peter. The Formal Basis of Modern Architecture. Zurich: Lars Müller Publishers, 2006c, p.180-182. 
Figura 30: Situação da Martin House. Fonte: EISENMAN, Peter. The Formal Basis of Modern Architecture. Zurich: Lars Müller Publishers, 2006c, p.188.

Figura 31: Deslocamento do eixo da pérgola e escaláo de acesso. Fonte: EISENMAN, Peter. The Formal Basis of Modern Architecture. Zurich: Lars Müller Publishers, 2006c, p.190.

Figura 32: Equilíbrio de eixos menores como "gangorra". Fonte: EISENMAN, Peter. The Formal Basis of Modern Architecture. Zurich: Lars Müller Publishers, 2006c, p.194.

Figura 33: Quebra da lareira e volume da sala de estar. Fonte: EISENMAN, Peter. The Formal Basis of Modern Architecture. Zurich: Lars Müller Publishers, 2006c, p.203.

Figura 34: Quebra entre eixos interno e externo. Fonte: EISENMAN, Peter. The Formal Basis of Modern Architecture. Zurich: Lars Müller Publishers, 2006c, p.203.

Figura 35: Situação da Coonley House. Fonte: EISENMAN, Peter. The Formal Basis of Modern Architecture. Zurich: Lars Müller Publishers, 2006c, p.207.

Figura 36: Referência Horizontal. Fonte: EISENMAN, Peter. The Formal Basis of Modern Architecture. Zurich: Lars Müller Publishers, 2006c, p.211.

Figura 37: Deformaçôes do acesso. Fonte: EISENMAN, Peter. The Formal Basis of Modern Architecture. Zurich: Lars Müller Publishers, 2006c, p.215.

Figura 38: Sistema dinâmico de volumes. Fonte: EISENMAN, Peter. The Formal Basis of Modern Architecture. Zurich: Lars Müller Publishers, 2006c, p.219.

Figura 39: Deslocamento ala lateral. Fonte: EISENMAN, Peter. The Formal Basis of Modern Architecture. Zurich: Lars Müller Publishers, 2006c, p.227.

Figura 40: Situação e diagonal externa. Fonte: EISENMAN, Peter. The Formal Basis of Modern Architecture. Zurich: Lars Müller Publishers, 2006c, p.239.

Figura 41: Principais deslocamentos da forma centroide. Fonte: EISENMAN, Peter. The Formal Basis of Modern Architecture. Zurich: Lars Müller Publishers, 2006c, p.243.

Figura 42: Torre como ponto fixo e espiral. Fonte: EISENMAN, Peter. The Formal Basis of Modern Architecture. Lars Müller Publishers, 2006c, p.253-257.

Figura 43: Pátio como referência horizontal e coberturas inclinadas. Fonte: EISENMAN, Peter. The Formal Basis of Modern Architecture. Zurich: Lars Müller Publishers, 2006c, p.265.

Figura 44: Sobreposição dos dois sistemas no Tallinn Museum. Fonte: EISENMAN, Peter. The Formal Basis of Modern Architecture. Zurich: Lars Müller Publishers, 2006c, p.271.

Figura 45: Giro provocado pelo acesso e ambiguidade do eixo do escaláo. Fonte: EISENMAN, Peter. The Formal Basis of Modern Architecture. Zurich: Lars Müller Publishers, 2006c, p.277-281.

Figura 46: Amortecimento e direcionamento do eixo de acesso. Fonte: EISENMAN, Peter. The Formal Basis of Modern Architecture. Zurich: Lars Müller Publishers, 2006c, p.284. 
Figura 47: Equilíbrio em torno do plano de referência horizontal. Fonte: EISENMAN, Peter. The Formal Basis of Modern Architecture. Zurich: Lars Müller Publishers, 2006c, p.286.

Figura 48: Situaçáo Casa del Fascio, eixo da praça. Fonte: EISENMAN, Peter. The Formal Basis of Modern Architecture. Zurich: Lars Müller Publishers, 2006c, p.292.

Figura 49: Distorçóes do cubo. Fonte: EISENMAN, Peter. The Formal Basis of Modern Architecture. Zurich: Lars Müller Publishers, 2006c, p.294.

Figura 50: Fachada em "H" e planos de entrada e baias quadradas. Fonte: EISENMAN, Peter. The Formal Basis of Modern Architecture. Zurich: Lars Müller Publishers, 2006c, p.296-298.

Figura 51: Comparação da fachada antiga e final a partir das divisôes. Fonte: EISENMAN, Peter. The Formal Basis of Modern Architecture. Zurich: Lars Müller Publishers, 2006c, p.302.

Figura 52: Divisões tripartidas em planta. Fonte: EISENMAN, Peter. The Formal Basis of Modern Architecture. Zurich: Lars Müller Publishers, 2006c, p.304.

Figura 53: Massa resistindo ao eixo diagonal e fachadas laterais. Fonte: EISENMAN, Peter. The Formal Basis of Modern Architecture. Zurich: Lars Müller Publishers, 2006c, p.306-308.

Figura 54: Fachada anterior. Fonte: EISENMAN, Peter. The Formal Basis of Modern Architecture. Zurich: Lars Müller Publishers, 2006c, p.310.

Figura 55: Deformaçôes da forma centroide pelo eixo externo e diagonal. Fonte: EISENMAN, Peter. The Formal Basis of Modern Architecture. Zurich: Lars Müller Publishers, 2006c, p.317.

Figura 56: Planta geral e plano horizontal. Fonte: EISENMAN, Peter. The Formal Basis of Modern Architecture. Zurich: Lars Müller Publishers, 2006c, p.320.

Figura 57: Plano horizontal marcado na fachada frontal e janela em fita na fachada lateral. Fonte: EISENMAN, Peter. The Formal Basis of Modern Architecture. Zurich: Lars Müller Publishers, 2006c, p.328.

Figura 58: Pilares da fachada lateral e volume lateral da forma "U". Fonte: EISENMAN, Peter. The Formal Basis of Modern Architecture. Zurich: Lars Müller Publishers, 2006c, p.332.

Figura 59: Colunas do pátio central. Fonte: EISENMAN, Peter. The Formal Basis of Modern Architecture. Zurich: Lars Müller Publishers, 2006c, p.332.

\section{Capítulo 03}

Figura 60: Plantas da House I do terreo e do primeiro pavimento. Fonte: EISENMAN, Peter et al. Five Architects: Eisenman, Graves, Gwathmey, Hejduk, Meier. Oxford University Press, 1975, p. 19-20.

Figura 61: Deslocamento no plano horizontal do cubo formando diagonal. Fonte: EISENMAN, Peter et al. Five Architects: Eisenman, Graves, Gwathmey, Hejduk, Meier. Oxford University Press, 1975, p.22.

Figura 62: Maquete House I, relação massa-superfície. Fonte: Site Eisenman Architects, disponível em 
https://eisenmanarchitects.com/House-I-1968. Acesso 04/02/2020.

Figura 63: Desenho dos planos a partir das colunas. Fonte: Elaborada pelo autor.

Figura 64: Planos com espessura. Fonte: Elaborada pelo autor.

Figura 65: Deslocamento dos dois quadrados formando divisão tripartida. Fonte: Elaborada pelo autor.

Figura 66: Plano inferido de outras referências; obstáculos e volumes negativos. Fonte: Elaborada pelo autor.

Figura 67: Duas sequências - A1-B1-A1-A1 e A2-B1-A1-B2-A2. Fonte: EISENMAN, Peter et al. Five Architects: Eisenman, Graves, Gwathmey, Hejduk, Meier. Oxford University Press, 1975. p.22.

Figura 68: Croquis de Eisenman para a House I que sugerem as sequências de volumes não flexionadas. Fonte: Site Eisenman Architects, disponível em https://eisenmanarchitects.com/House-I-1968. Acesso $04 / 02 / 2020$.

Figura 69: Extrapolação das sequências mais e menos comprimidas. Fonte: Elaborada pelo autor.

Figura 70: Planos de compressão a partir da lareira. Fonte: Elaborada pelo autor.

Figura 71: Dois quadrados deslocados e suas projeçôes. Fonte: Elaborada pelo autor.

Figura 72: Planos de referência em relaçấo à diagonal. Fonte: Elaborada pelo autor.

Figura 73: Volume quadrado qA nas fachadas Norte e Oeste. Fonte: Elaborada pelo autor.

Figura 74: Quadrados dos cantos vistos pela cobertura. Fonte: Elaborada pelo autor.

Figura 75: Quadrados com vazio central e diagonal fraca. Fonte: Elaborada pelo autor.

Figura 76: Diagonal alternativa e volumes simétricos. Fonte: Elaborada pelo autor.

Figura 77: Forma cruciforme no primeiro pavimento e vetor de compressão. Fonte: Elaborada pelo autor.

Figura 78: Aberturas e marcaçōes das superfícies. Fonte: Elaborada pelo autor.

Figura 79: Equilíbrio do acesso em torno do eixo deslocado e extensão da forma. Fonte: Elaborada pelo autor.

Figura 80: Diagonal pela supressão de vigas e volumes deslocados. Fonte: Elaborada pelo autor.

Figura 81: Deslocamento diagonal com eixos marcados. Fonte: Elaborada pelo autor.

Figura 82: Supressão de colunas e vigas marcando a diagonal. Fonte: EISENMAN, Peter et al. Five Architects: Eisenman, Graves, Gwathmey, Hejduk, Meier. Oxford University Press, 1975, p.22.

Figura 83: Diagonal centralizada no quadrado forte e planos aos quais a viga horizontal se remete. Fonte: Elaborada pelo autor.

Figura 84: Divisóes horizontais e deslocamento do térreo. Fonte: Elaborada pelo autor.

Figura 85: Fotos da House I com pré-existência e fotos internas. Fonte: Site Eisenman Architects, disponível em https://eisenmanarchitects.com/House-I-1968. Acesso 04/02/2020.

Figura 86: Croqui da situação sobre desenho de implantação da House I. Fonte: Compilação do autor. Desenho sobre imagem disponível em IZAR, Gabriela. Diagramática: descrição e criação das formas na arquitetura seriada de Peter Eisenman. Tese (Doutorado) - Curso de Arquitetura e Urbanismo, Universidade de São Paulo, São Paulo, 2015, p.158. 
Figura 87: Perspectiva isométrica com as aberturas e sequência ortogonal dos planos. Fonte: Compilação do autor. Desenho sobre imagem disponível em EISENMAN, Peter et al. Five Architects: Eisenman, Graves, Gwathmey, Hejduk, Meier. Oxford University Press, 1975, p.22.

Figura 88: Eixo externo alternativo. Fonte: Elaborada pelo autor.

Figura 89: Escalão, eixo de acesso e fachada tripartida. Fonte: Elaborada pelo autor.

Figura 90: Início da espiral no térreo e primeira curva. Fonte: Elaborada pelo autor.

Figura 91: Segunda curva da espiral no primeiro pavimento. Fonte: Elaborada pelo autor.

Figura 92: Terceira curva da espiral no primeiro pavimento. Fonte: Elaborada pelo autor.

Figura 93: Movimento final da espiral no pavimento superior. Fonte: Elaborada pelo autor.

Figura 94: Espiral na divisão tripartida. Fonte: Elaborada pelo autor.

Figura 95: L deslocado e volumes fragmentados em isométrica. Fonte: Compilação do autor. Desenho sobre imagem disponível em EISENMAN, Peter et al. Five Architects: Eisenman, Graves, Gwathmey, Hejduk, Meier. Oxford University Press, 1975, p.22.

Figura 96: Volume central da forma genérica fragmentado e cata-vento. Fonte: Elaborada pelo autor.

Figura 97: L deslocado do térreo para o primeiro pavimento. Fonte: Elaborada pelo autor.

Figura 98: Grelha de volumes intercalados. Fonte: Elaborada pelo autor.

Figura 99: Deslocamento de eixo, vigas e volumes na diagonal. Fonte: Elaborada pelo autor.

Figura 100: Espiral aflorando nas fachadas. Fonte: Elaborada pelo autor.

Figura 101: Equilíbrio horizontal. Fonte: Elaborada pelo autor.

Figura 102: Comparativo entre a diagonal da House I e da House II. Fonte: Compilação do autor. Desenho elaborado pelo autor com imagens disponíveis em EISENMAN, Peter et al. Five Architects: Eisenman, Graves, Gwathmey, Hejduk, Meier. Oxford University Press, 1975, p.22-35.

Figura 103: Diagonal House I como o deslocamento de dois cubos tripartidos. Fonte: Elaborada pelo autor.

Figura 104: House I, sobreposição de dois nine-square. Fonte: Elaborada pelo autor.

Figura 105: Nine-square com a diagonal marcada. Fonte: Elaborada pelo autor.

Figura 106: Dois eixos no sentido principal de cada quadrado extrudado. Fonte: Elaborada pelo autor.

Figura 107: Extrusão dos eixos menores de cada quadrado. Fonte: Elaborada pelo autor.

Figura 108: Comparativo estre as grelhas da House I e da House II. Fonte: Elaborada pelo autor.

Figura 109: Deslocamento entre os quadrados da House II. Fonte: EISENMAN, Peter et al. Five Architects: Eisenman, Graves, Gwathmey, Hejduk, Meier. Oxford University Press, 1975, p.32-35. 


\section{Capítulo 04}

Figura 110: Desenhos conceituais e perspectiva isométrica da House III. Fonte: Site Eisenman Architects, disponível em https://eisenmanarchitects.com/House-III-1971, acesso 05/02/2020.

Figura 111: Desenhos conceituais da House IV. Fonte: Site Eisenman Architects, disponível em https:// eisenmanarchitects.com/House-IV-1971, acesso 05/02/2020.

Figura 112: Imagens conceituais da House VI. Fonte: Site Eisenman Architects, disponível em https:// eisenmanarchitects.com/House-VI-1975, acesso 05/02/2020.

Figura 113: Imagens conceituais da House X. Fonte: Site Eisenman Architects, disponível em https:// eisenmanarchitects.com/House-X-1975, acesso 05/02/2020.

Figura 114: Maquete Fin D'Ou T Hou S. Fonte: Site Eisenman Architects, disponível em https:// eisenmanarchitects.com/Fin-D-Ou-T-Hou-S-1983, acessado em 05/02/2020. 
○

䓛 
1.1. Narrativas de formação

1.2. Linhas de absorção

2. Eisenman Crítico

2.1. Ordem Total: as bases formais da arquitetura moderna

2.2. Sistemas formais: o projeto moderno reexaminado 60

2.3. Estrutura Profunda e arquitetura conceitual

3. Eisenman Arquiteto

3.1. House I, o desenho da teoria: estrutura profunda e autonomia autorreferente

3.2. House I, a crítica ao desenho: ambiente total e autonomia da forma

3.3. House I, o projeto como pesquisa

4. Consideraçóes finais

4.1. House I - Da Tese à Série

4.2. House I - Da Série à Carreira

4.3. Desdobramentos da pesquisa 


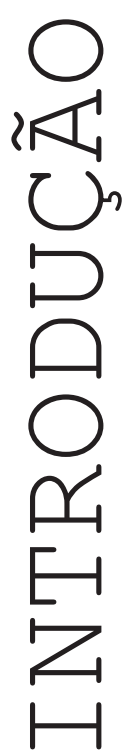


Notável arquiteto, Peter Eisenman é uma referência no mundo por suas obras e seus textos arquitetônicos. Importante projeto que desenvolve é o Memorial aos Judeus Assassinados da Europa, inaugurado em 2005 em Berlim. Em palestra na Architectural Association de Londres, em 2006, o arquiteto discorreu sobre a recepção deste seu projeto na capital alemá. Nela, Eisenman comenta a utilização da imagem deste memorial por um partido político italiano em panfleto ligado à memória do holocausto ao qual fora sobreposta uma estrela de Davi: "O que me interessa nesse cartaz é que eles se sentiram obrigados a sobrepor a estrela de Davi àquele campo que é o nosso projeto em Berlim. Aparentemente eles sentiram que ninguém seria capaz de ler tal campo sem a estrela de Davi." (EISENMAN; KOOLHAAS, 2014b, p.23). O comentário sintetiza uma questão presente em toda a carreira de Eisenman, o sentido ou significado da forma arquitetônica: não é uma condição inerente ao projeto a obrigatoriedade de representar a mensagem proposta pelo partido sem o reforço do símbolo judaico. Independente de o projeto ser desenvolvido como monumento de memória, o que pressupõe uma função simbólica, a forma arquitetônica não traria uma correspondência direta fora do campo arquitetônico, isto é, ela não representaria nada externo à arquitetura.

Esta condição, na qual o projeto necessita do amparo de um símbolo externo para circular em meio extra-arquitetônico, marca a proposta de Eisenman e o modo como ele compreende a autonomia da arquitetura: "Acho que concordamos que você [Rem Koolhaas] e eu estamos tentando fazer projetos expressivamente neutros, sei que eu estou tentando fazer este tipo de projeto. [...] Sou contra a opticalidade no sentido de espetáculo visual. Estou interessado na ilegibilidade. (EISENMAN; KOOLHAAS, 2014b, p.53-55)". A partir dessas colocaçóes do arquiteto, podemos identificar que a autonomia por ele proposta parte de uma ruptura na unidade entre forma e conteúdos, estes últimos considerados pelo arquiteto como externos à disciplina; neste caso, o sentido, a função simbólica do projeto.

Questão presente na carreira de Eisenman já no início dos anos 1980, é possível encontrála nas críticas de Koolhaas e Rafael Moneo aos trabalhos por ele desenvolvidos à época para o concurso do IBA Housing, também em Berlim: “[...] Koolhaas criticou a intenção de Eisenman, argumentando que não há 'garantias de que [o IBA] será percebido como nada mais do que uma neurose pessoal"”; enquanto Moneo notara que "o grid é seu contexto artificial... sua própria sintaxe... Ele está falando uma linguagem em que palavras perderam seu sentido.” Problematizaçóes a que Eisenman responderia: "Se for possível de se fazer palavras esvaziadas de sentido, eu gostaria de tentar fazer isso.” (YAMAMOTO, 2014, p.80)ํ. Na discussão, percebe-se o recurso a questôes

1 Narrativa também apresentada por Cynthia Davidson (2006b, p. 27). 
de linguagem: "palavras esvaziadas de sentido", evidenciando a noção de autonomia proposta por Eisenman pautada por uma preocupação eminentemente sintática, com as regras e operaçóes da forma no lugar de questões semânticas ou problemas de representação. Outros termos importantes que aparecem no debate são: "grid", ou a grelha, elemento de estrutura da forma; e "neurose pessoal", indicando o reconhecimento da participação do arquiteto no processo.

$\mathrm{Na}$ verdade, esta busca de Eisenman por compreender a arquitetura desvinculada de sentidos externos à arquitetura, de valor de representação, está presente desde o início de sua carreira. Retomando sua tese apresentada em Cambridge em 1963 - The Formal Basis of Modern Architecture (EISENMAN, 2006c) -, encontramos Eisenman tentando resgatar um lado crítico, lógico da arquitetura, pautado pelos processos internos à forma, afastando-se questôes de representação, função e história. Já então, Eisenman buscava criticar e colocar em questão a "linguagem natural e clássica da arquitetura” (EISENMAN, 2004a, p. IX), compreendida como o discurso da arquitetura formulado a partir do Renascimento e operante até o Modernismo.

A Tese de Eisenman foi pouco difundida até bem recentemente. Apenas em 2006 foi publicada em fac-símile pela editora Lars Müller, 43 anos após a sua defesa em Cambridge. Ao longo de sua carreira, o próprio arquiteto pouco se remeteu ao conteúdo desse trabalho. No mesmo ano de 1963, ele publicara o texto Towards an Understanding of Form (EISENMAN, 1963), no qual explicitava alguns dos pontos fundamentais da tese. Porém, em suas publicaçôes seguintes, a partir de 1970 - como nos textos Dall'Oggetto alla Relazionalità (EISENMAN, 1970a) e Notes on Conceptual Architecture (EISENMAN, 1970b) -, suas propostas são sensivelmente diferentes da Tese, aproximando-se de modo explícito da gramática generativa de Noam Chomsky. Consequência disto, a maioria das leituras das ideias e da obra do arquiteto partem dos pressupostos fixados a partir da década de 1970. Ocorre que, justamente neste hiato entre a tese e tais escritos, Eisenman desenvolveria seus dois primeiros projetos: a House I, de 1967, e a House II, de 1969.

Esta pesquisa nasceu da tentativa de retomar o projeto da House I à luz dessa transição teórica ocorrida no pensamento de Eisenman em seus anos de formação na década de 1960, partindo do pressuposto de que este projeto e o seguinte, a House II, desenvolvidos neste período, indiciam essa mudança. A recepção desses dois projetos é fortemente pautada por textos explicativos de Eisenman publicados no livro Five Architects (EISENMAN et al., 1975), resultado da exposição realizada no MoMA de Nova York, em 1969; nesta publicação, os dois projetos são apresentados como igualmente afinados com o que o arquiteto defendia no período. Assim, nesta dissertação, procuraremos retomar o projeto da House I tomando como ponto de partida a sua Tese, para, além 22 
de investigar as ferramentas de análise e projeto propostos no livro The Formal Basis of Modern Architecture (EISENMAN, 2006c) e sua operatividade, explorar as relaçôes entre a teoria e o projeto no início da carreira do arquiteto, de modo a expandir a compreensão da House I.

É verdade que as fases da obra de Eisenman são amparadas por estruturas diferentes ${ }^{2}$, há, porém, uma permanência de questôes relativas à discussão contemporânea sobre arquitetura. A ideia aqui é situar esse projeto não como um ponto de início em sua carreira, mas concebê-lo como uma transição entre a Tese e momentos posteriores da carreira do arquiteto, entre sua fase inicial, as bases formais da arquitetura, e a primeira fase de seu trabalho, as Transformaçóes. Com efeito, o modo pelo qual abordaremos a House I inspira-se no modo como o próprio Eisenman discute o seu projeto da House X. Em seu livro homônimo, o arquiteto propóe discutir a House X a partir das vozes de dois "Eisenmans" (EISENMAN, 1982, p. 33-38): um do novo período, que percebe inaugurar neste projeto e denomina Decomposição; e o Eisenman dos projetos anteriores, da série de casas, o qual ele denomina Transformaçóes. No livro, Eisenman marca a House $X$ como um projeto já do novo estágio, mas que poderia ser lido na chave do estágio anterior; com essa leitura dual permanece a ambiguidade: não há um ponto de chegada que elimine uma das leituras. Apesar desta colocação de Eisenman, o projeto consagrou-se em sua fortuna crítica como fim do período de Transformaçóes, o projeto inaugural das Decomposiçóes afirmando-se como o do Cannaregio ${ }^{3}$. De fato, é possível afirmar a respeito de sua obra que há a permanência de questóes ao longo de seu desenvolvimento, a ausência de fortes rupturas, com um mero amadurecimento de ideias, com algumas mudanças por certo, mas, sobretudo, com permanências e retomadas. Seja como for, considerando que há diferenças em suas fases, é possível caracterizar dois tipos de projetos de Eisenman: alguns como explorações de ideias do arquiteto, projetos intermediários, como a série de casas; e outros, marcando mudanças significativas de seu pensamento, pontos de inflexão que guardam leituras ambíguas, até em certos aspectos divergentes, tal como a House $X$ é apresentada na leitura do próprio arquiteto. $\mathrm{O}$

2 A carreira de Eisenman pode ser dividida em diferentes fases, como veremos adiante. Uma das divisões mais aceitas separa sua carreira em três fases, marcando diferentes referências teóricas de Eisenman. A primeira fase, das Transformações, da década de 1960 até 1975, é definida pela série de casas e pela associação à gramática generativa de Noam Chomsky. Segunda fase, as Decomposições, compreende o projeto para o Cannaregio de 1978, até final da década de 1980; esta fase é quando Eisenman aproxima-se da desconstrução de Jacques Derrida. O fim deste período é marcado por tensão entre o arquiteto e o filósofo. Terceira fase é da década de 1990 em diante, quando Eisenman aproxima-se do diagrama e do conceito de dobra de Deleuze e Guatarri. Como teremos oportunidade de ver adiante, divisões em fases aparecem em textos do próprio arquiteto (EISENMAN, 1982, 1999, 2004b, 2007 e 2008a), entretanto, para exemplos de autores que exploram Eisenman a partir destas fases, ver: Cynthia Davidson (2006a), Gabriela Izar (2015), Jeffrey Kipnis (1998 e 2007), Rafael Moneo (2008), Gentil Porto Filho (2004), Robert Somol (1999) e João Carlos Amaral Yamamoto (2014).

3 A divisão entre duas fases a partir do projeto para o Cannaregio de 1978 é talvez a mais relevante na carreira do arquiteto, tanto que é a principal em seu livro Diagram Diaries (EISENMAN, 1999), destacando-se dois momentos: um marcado por diagramas de interioridade; outro, por diagramas de exterioridade. 
que se propóe nesta dissertação é, portanto, apanhar a House I em posição análoga àquela sugerida pelo arquiteto quanto à House $X$. Do mesmo modo que esta se situa entre a Transformação e a Decomposição, a House I está entre a Transformação e as ideias suscitadas em sua Tese, as bases formais da arquitetura.

O processo será realizado em cinco momentos. Primeiro, por meio de uma rápida reconstituição da carreira de Eisenman, particularmente o início (Capítulo 1.1), e de como se deu a recepção da House I e de sua Tese, The Formal Basis of Modern Architecture (EISENMAN, 2006c) (Capítulo 1.2). Em seguida, será formulada uma estrutura geral da Tese de Eisenman, por meio da compreensão de seus principais pontos (Capítulo 2.1) e do modo como ele desenvolve um conjunto de leituras de projeto nessa publicação (Capítulo 2.2). O objetivo é encontrar as concepçôes e categorias teóricocríticas elaboradas pelo arquiteto naquele momento. Posteriormente, este trabalho passa em revista os textos de Eisenman do início da década de 1970, à procura daquilo que ele defende no período de realizaçáo de seus primeiros projetos, compondo uma segunda estrutura que permitirá traçar diferenças com a proposta anterior (Capítulo 2.3). Com este contexto formado, analisaremos a House I, primeiro a partir do que o arquiteto apresenta deste projeto e do modo como ele o insere na fase das Transformaçóes em sua obra (Capítulo 3.1), para, em um segundo momento, produzirmos uma análise alternativa a partir do exposto em sua Tese (Capítulo 3.2); essas duas leituras permitirão algumas relaçôes, lançando novas questôes sobre o projeto (Capítulo 3.3). Outrossim, exploraremos algumas conclusóes contrapondo os objetos de análise em relação ao período da série de casas, Transformaçôes, sua arquitetura conceitual (Capítulo 4.1), e em relação ao início da fase seguinte, das Decomposições (Capítulo 4.2). Por fim, procuraremos extrair alguns possíveis desdobramentos, caminhos pelos quais o tipo de estudo realizado poderia prosseguir (Capítulo 4.3). 
$\sum_{1}^{Z}$
$Z 1$
0
$1+1$
$[1]$

[I]

○

U

[I]

20

U

$\sum_{0}^{4}$

II

$\Omega$

Z

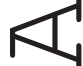

$\Omega$

EI

$\sqrt{1}$ 


\subsection{Narrativas de formação}

Peter Eisenman é arquiteto de influência internacional. Consequência de uma atuação em face da disciplina, sua arquitetura é, por vezes, denominada arquitetura crítica (KIPNIS; SOMOL, 2014). No decorrer de sua carreira, desde a década de 1960 até os dias atuais, o arquiteto participou de diferentes frentes institucionais, em projeto, ensino, pesquisa, curadoria, fundou revistas, instituiçôes, entre outros empenhos. Somol o descreve como um "articulador institucional e político" (KIPINIS; SOMOL, 2014, p. 83), e autores como Cynthia Davidson (2006b), Charles Jencks (1989), Rafael Moneo (2008) e Sophia Teles (1993) salientam a vastidão de sua produção. A partir desses distintos pontos de vista e de colocaçóes do próprio arquiteto, podemos elaborar visão panorâmica de sua carreira, particularmente do início, foco desta pesquisa.

Nascido em 1932, Eisenman formou-se arquiteto nos Estados Unidos em 1960, na Universidade de Columbia. Trabalhou no escritório de Walter Gropius antes de ir a Cambridge, na Inglaterra, onde desenvolveu o seu Ph.D, The Formal Basis of Modern Architecture (EISENMAN, 2006c), apresentado em 1963; nele, Eisenman analisa a arquitetura a partir de consideraçôes formais. Alegando que a arquitetura moderna pende para o lado da história e da função, o arquiteto propôs ali desvincular o projeto desses elementos, que denomina "culturalmente condicionados", e retomar o que ele chamava de fundamentos lógicos da forma.

Nesse período, Eisenman entrou em contato com importantes figuras e ideias. Aproximou-se de Colin Rowe, com quem fez viagem pela Europa em 1960 (EISENMAN, 2008b), e por meio deste travou contato com a noção de diagrama como ferramenta de leitura, com a tradição formalista, com as ideias de Rudolf Wittkower e com suas leituras da obra de Palladio. Foi na Europa que ele conheceu o trabalho de Terragni e, na viagem com Rowe, visitou a Casa del Fascio em Como, na Itália. Em Cambridge, também entrou em contato com Christopher Alexander, antítese para Eisenman em função de suas pesquisas sobre o diagrama como forma de parametrizar a arquitetura, como processo de resolução do problema arquitetônico de forma análoga ao de uma equação matemática, partindo da função. Durante sua estadia na Inglaterra, iniciou também sua prática pedagógica, ministrando aulas como professor adjunto no estúdio do primeiro ano. Em 1963, apresentou a sua Tese e publicou o artigo Towards an Understanding of Form (EISENMAN, 1963), texto que apresenta em linhas gerais as ideias de sua Tese.

Findos seus estudos, Eisenman retornou aos EUA, onde prosseguiu na pesquisa, ensino e iniciou sua prática projetual. A primeira fase de sua obra, que ele denominou Transformaçóes, foi 
marcada pelo conjunto de projetos de casas numerados sequencialmente: House I, House II, House III, House IV, House VI, House VIII e House X. Elaborados de 1967 a 1975, eles originam-se de transformaçóes a partir do cubo, visando à supressão de toda forma de representação em favor do projeto enquanto expressão de seu próprio processo de feitura, como sequência de transformaçóes que visam à construção da forma por processo lógico. Autorreferentes, autônomos, fechados sobre si mesmos, foi assim que tais projetos foram frequentemente descritos ${ }^{1}$. Estes projetos de casas apresentam o vocabulário de Eisenman partindo de formas próximas às de Le Corbusier e Terragni, apartados do meio, ensejando uma abstração da forma, preocupada com a sintaxe autônoma em detrimento da semântica. Esse conjunto de projetos colocaria em questão conceitos tradicionais da arquitetura, como o próprio sentido dos termos casa, habitar, abrigo, estrutura, o que um pilar representa (sustentação, estabilidade), deslizados semanticamente, desestabilizados na busca pela estrutura mesma da forma arquitetônica.

Seu primeiro projeto, a House I, ou Pavilhão Barenholtz, de 1967, é fortemente influenciado pela Casa del Fascio, de Terragni - partindo do deslocamento entre dois cubos, a sua disposição em diagonal motivará as operações formais propostas. A House II, de 1969, prossegue no estudo da diagonal sobre o cubo - elaborando o tema da ambiguidade estrutural, o projeto parte de dois sistemas estruturais: um de pilares e vigas; e o outro, de planos; esta residência é um marco da abstração operada por Eisenman, enfatizada pelas fotos publicadas da construção: situada no topo de uma colina, onde, com a neve, gera-se uma incerteza sobre ela ser uma imagem do edifício ou de sua maquete. A House III, de 1971, estuda a sobreposição de duas malhas não ortogonais entre si, em $45^{\circ}$, parcialmente sobrepostas; esta ideia é retomada em desenhos de uma possível House $V$ (MONEO, 2008). A House IV, também datada de 1971, explora as relações entre centro e periferia e é marco do projeto como apresentação de seu processo - a forma final é como a sobreposição de diferentes etapas do processo de geraçáo da forma; o arquiteto apresentou este projeto como uma animação, ilustrando a sequência de transformaçôes do cubo. A forma como foi apresentado na exposição Deconstructivist Architecture, anos depois, em 1988, é exemplar da força desse processo. Esta expôs a formação da casa por uma sequência de desenhos marcando as sucessivas etapas do cubo à forma final.

Esta sequência inicial, da House I à House $I V$, é marcada em texto de Eisenman da época, Cardboard Architecture (EISENMAN, 1973a), de 1973, e o texto House VI (EISENMAN, 1977),

1 Ver Charles Jencks (1989), Montaner (2001), Gabriela Izar (2015), Rafael Moneo (2008), Gentil Porto Filho (2004) e João Carlos Amaral Yamamoto (2014). 
de 1977, como um grupo distinto do que ele viria a explorar a partir da House VI. Nesses textos, o arquiteto diz que, diferentemente das casas seguintes, as quatro primeiras são variaçôes sobre o cubo. A denominação Cardboard Architecture, "arquitetura de papelão", não é aplicada à série toda, mas justamente a essas quatro primeiras casas. A ideia de associar projetos ao "papeláo" traz a tentativa de desvinculá-los de sentidos consolidados, de questionar a natureza de nossa percepçáo da realidade, e, consequentemente, do signo; como Otilia Arantes (1993, p. 76) notou, trata-se de projetos que procuram ser signos de si mesmos. Ao se aproximar do material de maquete, Eisenman procura instigar a dúvida sobre se edifício ou maquete, como patente na House II. Questão importante acerca destas quatro primeiras casas é a frontalidade, isto é, o edifício é estruturado a partir do plano frontal; em diálogo com a tradição arquitetônica, essa característica evoca a arquitetura clássica, que lhe chega pelo modernismo tanto de Terragni quanto de Le Corbusier. Também a frontalidade é meio pelo qual Eisenman dialoga com a transparência de Colin Rowe e Robert Slutzky.

Foi nesta fase em que Eisenman se aproximou da linguística, particularmente a de Noam Chomsky. Durante o período, Eisenman publicou importantes textos para a compreensão de suas ideias, como Dall'Oggetto alla Relazionalità (EISENMAN, 1970a), Notes on Conceptual Architecture (EISENMAN, 1970b) e From Object to Relationship II (EISENMAN, 1971). Neles, cita pela primeira vez Chomsky, utilizando categorias como "estrutura profunda”, uma dimensão conceitual que define as regras da forma, e "estrutura aparente", as formas, o perceptível. Em Notes on Conceptual Architecture, ele aproxima sua exploraçáo de uma arquitetura focada na sintaxe à arte conceitual e, ao aprofundar a análise da Casa del Fascio iniciada em sua Tese, o arquiteto passa a compreendêla a partir da ideia das duas estruturas, situando sua principal virtude não no edifício em si, nem em quaisquer elementos semânticos, mas nas relaçóes formais entre seus elementos, ou seja, na dimensão de sintaxe nela contida. Eisenman retira a importância do objeto transferindo-a para a estrutura das relaçóes formais.

As House VI, House VIII e House X, todas datadas de 1975, marcariam uma segunda etapa da fase das Transformaçóes. A House VI parte de um centro, da intersecção de dois planos ortogonais entre si, dividindo o cubo inicial em quatro partes; estes dois planos são utilizados como planosreferência das operações formais. Na House VIII, esse centro abre como vazio, culminando na House $X$, na qual esse vazio irrompe, subdividindo o cubo em outros quatro cubos menores. O processo de produção de uma arquitetura de sintaxe, de relaçóes entre elementos, chega ao patamar no qual o produto escolhido como final da House $X$ não é mais uma edificação, mas uma perspectiva axonométrica. Nesses projetos, a articulação do cubo amplia para além do cubo abstrato, associando- 


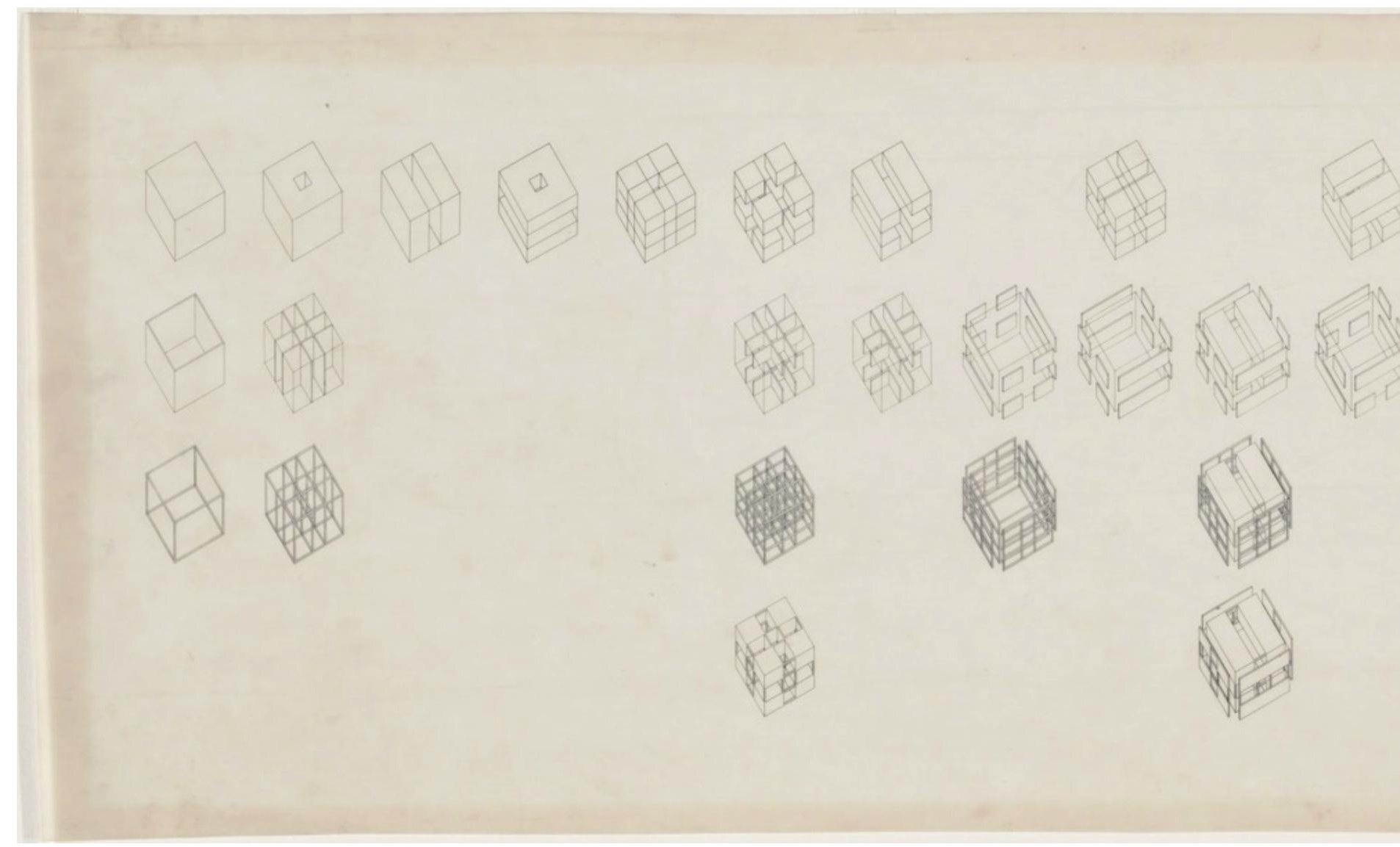

Figura 1 - Sequência de transformações do projeto da House IV. Fonte: Site Museum of Modern Art (MoMA).

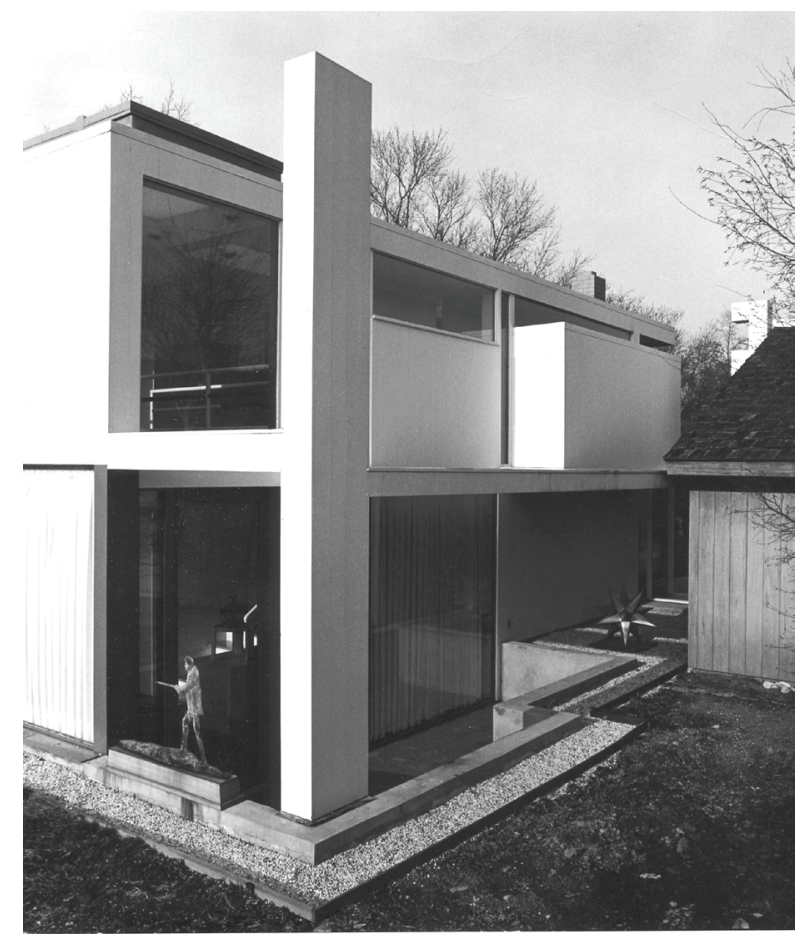

Figura 2 - House I. Fonte: Site Eisenman Architects.

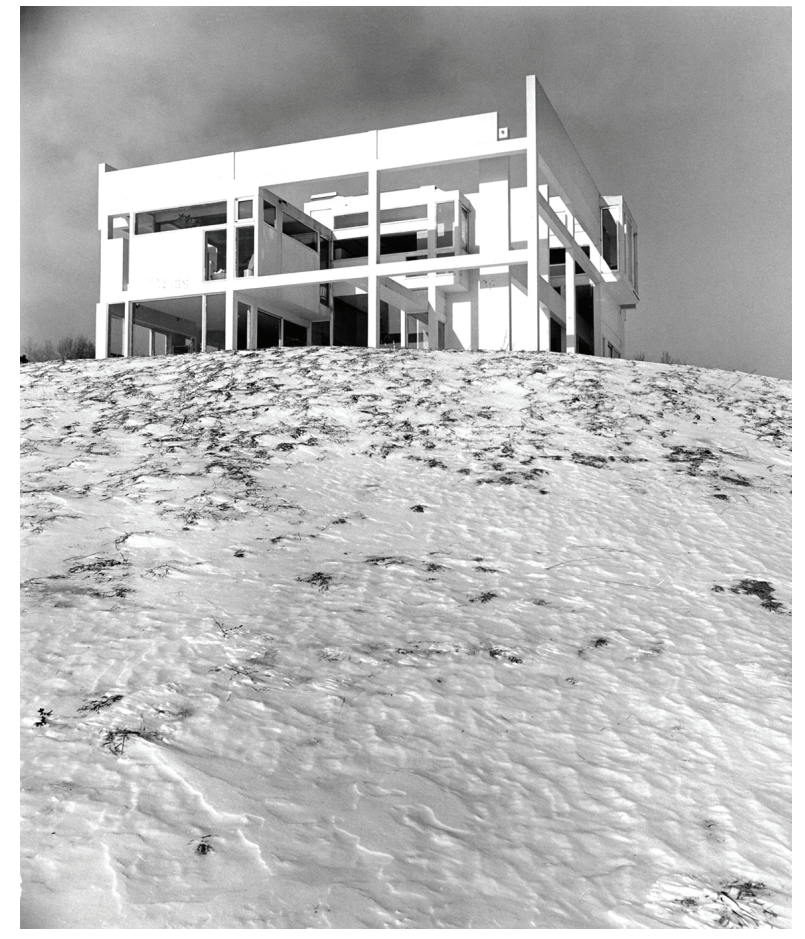

Figura 3 - House II. Fonte: Site Eisenman Architects. 

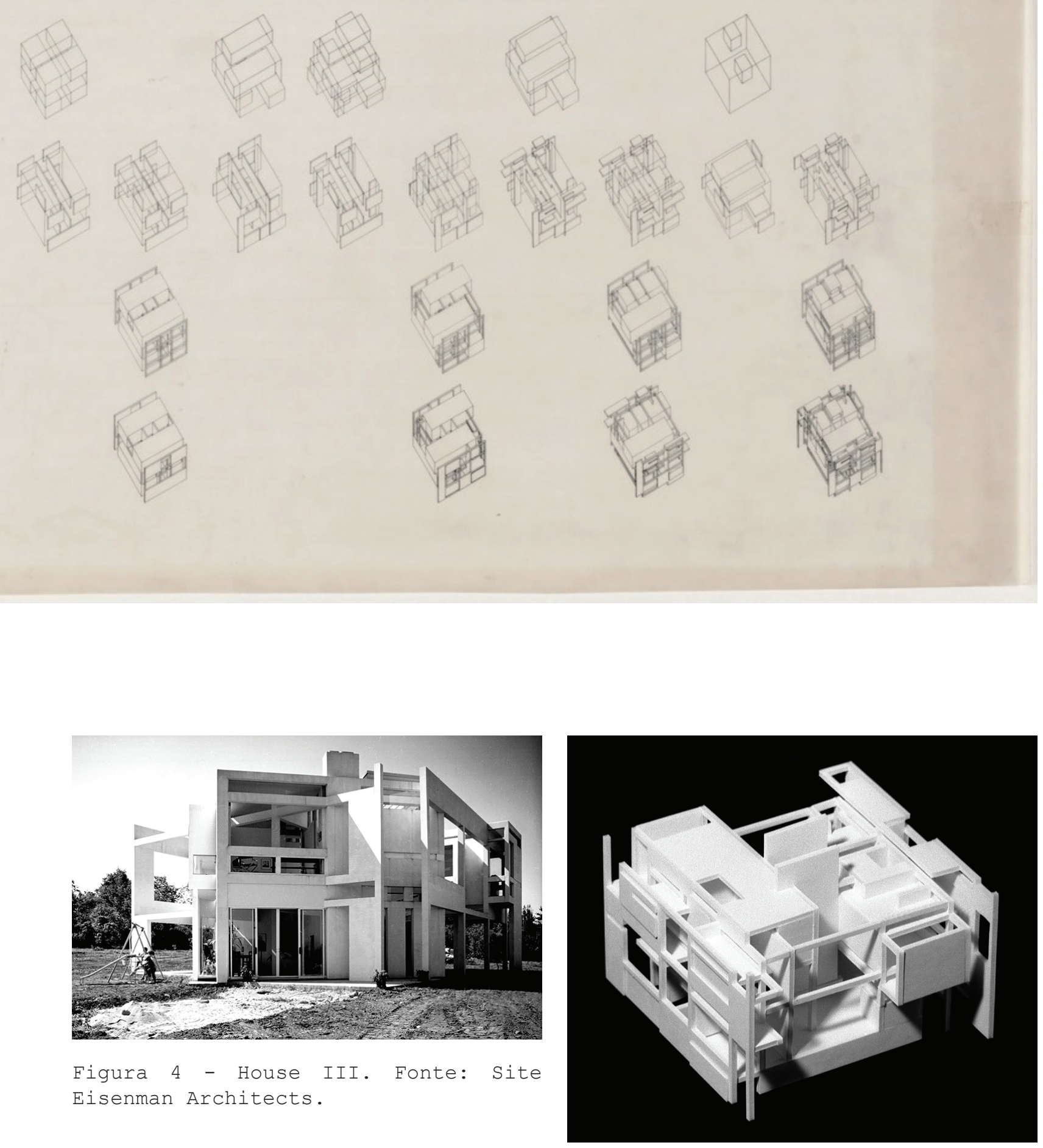

Figura 4 - House III. Fonte: Site Eisenman Architects.

Figura 5 - Maquete House IV. Fonte: Site Eisenman Architects. 
se progressivamente a elementos externos como o solo, o terreno local, a cor vermelho-terra na base da House VI ou à própria topografia que acomoda os cubos da House X. A House X marca, portanto, um ponto de chegada do desenvolvimento formal abstrato de Eisenman - neste projeto, o arquiteto encontra uma unidade, a forma "El”, que é um cubo com um cubo menor subtraído, elemento que será repetido, rotacionado, escalonado, para formar a House XIa, de 1978.

A busca por uma equivalência entre o processo de elaboração do projeto e de sua leitura leva à remoção de camadas consideradas condicionadas, como a função representativa da forma. No texto Notes on Conceptual Architecture II A (EISENMAN, 1973b), Eisenman compreende que a estrutura profunda não é única, mas plural - não há, então, uma única camada de regras formais, no lugar da estrutura profunda única há um conjunto fragmentado. Não há, portanto, uma única estrutura oriunda da sintaxe da forma, como um valor absoluto, no lugar de um centro estável, surge o vazio. $\mathrm{Na}$ House VI, aparece, além dos dois planos verticais, a relação com o solo, tanto no embasamento em cor vermelho-terra, quanto na relação entre o acima e abaixo das escadas, marcadas em verde e vermelho.

Concomitantemente a essa fase, ao retornar aos EUA, Eisenman iniciou as CASEs (Conference of Architects for the Study of the Environment); a primeira delas ocorreu em 1964, prosseguindo ate a última, em 1974. Como, em seu entendimento, elas não tiveram vida longa, ele posteriormente as denominaria de "criança feia e mal-formada" (SCHIAVO, 2016, p.21). A CASE de 1969 resultou na exposição e no livro Five Architects (EISENMAN et al., 1975), seis anos depois; nele, Eisenman apresentou seus projetos da House I e da House II, ao lado de projetos de Charles Gwathmey, John Hejduk, Richard Meier e Michael Graves. Incentivado por Philip Johnson, o livro apresenta as obras e contém textos introdutórios de Kenneth Frampton e Colin Rowe. Se a ideia de um grupo é uma construção tensa, estes apresentam todas as dificuldades de coesão entre as obras e arquitetos ali figurados. Robert Somol (1999) destacou posteriormente a fragilidade desse grupo como consequência de ter sido construído de fora, graças ao empenho pessoal de Philip Johnson.

Após as CASEs, Eisenman dedicou seu empenho institucional ao IAUS (The Institute for Architecture and Urban Studies), iniciado em 1967 e que durou até 1984; o IAUS foi um importante local de discussão e ensino informal naquele momento. Igualmente, um importante espaço de representação das discussôes e atividades do IAUS foi a revista Oppositions, publicada de 1973 a 1984 - polo de discussão contemporânea de arquitetura, ela se tornou referência para algumas das mais importantes discussóes teóricas do período, como a semiologia, a fenomenologia, o marxismo, o estruturalismo e o pós-estruturalismo em arquitetura. Nesses anos, a revista recebeu contribuição 32 
de nomes como os de Diana Agrest, Alan Colquhoun, Francesco Dal Co, Kurt W. Forster, Kenneth Frampton, Mario Gandelsonas, Giorgio Grassi, Rem Koolhaas, Rafael Moneo, Joan Ockman, Aldo Rossi, Colin Rowe, Denise Scott Brown, Ignasi de Solà-Morales, Manfredo Tafuri, Bernard Tschumi e Anthony Vidler, além do próprio Eisenman.

Com o livro House X (EISENMAN, 1982), publicado em 1982, Eisenman descreveu seu conjunto inicial de projetos de casas como uma unidade, por meio da ideia de uma pesquisa sequencial, daquilo que chamou de Transformaçóes. Amarrando desde a House I até a House X, o livro apresentou também a transição para a fase seguinte ao argumentar que, na House $X$, teria início um processo diferente, de Decomposição. A House XIa, posterior à House X, por exemplo, foi assim excluída dessa sequência, mesmo sendo elaborada a partir de formas "El”; retomando neste projeto a relação acima/abaixo da House VI, o arquiteto propôs uma composição que partia da superfície do solo para o céu e dela para a terra, por meio de um gesto de escavação, estabelecendo assim a distinção entre céu, ar, e terra.

Essa sua segunda fase, de Decomposição, ou de escavaçôes artificiais, é marcada pelo afastamento das ideias de Noam Chomsky e pela aproximação à filosofia da desconstrução de Jacques Derrida. Eisenman passa a considerar suas decomposiçóes como forma da desconstrução em arquitetura, tal como se posiciona no livro House X (EISENMAN, 1982). A partir da Transformação, a forma é elaborada por processo de composição. Nesse estágio, a estrutura profunda implica relaçôes que se desdobram em uma narrativa de formação do projeto. Decompor é desfazer, o arquiteto não produz o objeto, mas o analisa; diferente do processo da Transformação, no qual narra o fazer, agora é uma narrativa do que é possível apreender de um objeto já formado que se apresenta ao arquiteto. Em oposição às operaçóes lógicas da primeira fase, neste momento, propóe-se o que ele chama de operaçóes analógicas.

O que até então surgia como uma tentativa de continuar o projeto moderno torna-se uma ruptura com ele. Em vez de procurar remover todas as camadas de sentido previamente determinadas em prol de um sentido inerente à forma, prosseguindo o projeto moderno pela abstraçáo, Eisenman retornaria ao mundo da vida, a elementos pré-existentes no local, passando a discutir a impossibilidade de um sentido estável. O texto Pós-Funcionalismo (EISENMAN, 2006b), de 1976, inaugura a cisão ao situar o modernismo como uma forma de humanismo. Para Eisenman, a forma, ou tipo, e a função, ou programa, teriam origem no Renascimento. No período pré-industrial, o equilíbrio entre esse par era garantido pela visão idealizada do homem no mundo. Apesar de esta visão começar a ser alterada com a Revolução Industrial, o homem teria se mantido como referência, pois a premissa 
de que a forma segue a função teria ainda o homem como medida, ainda que não diretamente, mas através do uso e das atividades humanas. Rompendo com o modernismo, Eisenman propóe que compreendamos esse binômio de forma dialética, ambos contribuindo de maneira equivalente, sem predominância de um sobre o outro, para a composição da forma e do ambiente. O texto The End of the Classical: The End of the Beginning, the End of the End (EISENMAN, 1984), de 1984, traça definitivamente essa ruptura com o movimento moderno. Nele, Eisenman argumenta que a arquitetura clássica, a que tem origem no Renascimento e se estende até o Modernismo, baseia-se em três ficçôes: a ficção da representação, a qual, a despeito das tentativas em contrário, o moderno preserva, substituindo a representação clássica pela representação da função; a ficção da razão, segundo a qual há um sentido de verdade, outrora enraizado na ideia de Deus e posteriormente na ideia de ciência, mediada arquitetonicamente pela ideia de homem vitruviano; a terceira é a ficção da história, a tentativa de retomar no passado clássico uma fonte atemporal, ou, à maneira do modernismo, rejeitando a história para assumir-se como eterno ou universal.

Marco do início da fase das Decomposições é o projeto para a região do Cannaregio em Veneza, de 1978. Nele, Eisenman retorna ao contexto urbano, à relação do projeto com o que o circunda. Elaborado não a partir de transformaçóes do cubo, mas através de uma arqueologia do local, o projeto define-se pela sobreposiçấo de diferentes elementos locais: a malha medieval de Veneza; a referência aos dois eixos Cardeno e Decumanos; a malha de projeto de hospital, que Le Corbusier havia proposto para o local; e repetiçóes de projeto próprio, a House XIa. Remetendo à outra denominação desta fase como Cidades das Escavaçóes Artificiais, o projeto não é uma leitura de Veneza como se houvesse um ponto de vista neutro, mas, sim, uma leitura orientada por quem a faz, uma leitura artificial. Portanto, não é uma leitura impessoal e presente independente de quem a lê. Eisenman questiona a possibilidade de um sentido estável - as diferentes malhas do projeto compóem a situação urbana como relação, impedindo que seja fixada qual é a estrutura de Veneza. Sua repetição do projeto da House XIa em três diferentes escalas prossegue no sentido de desestabilizar o conceito de casa a partir de uma operação analógica dada pela justaposição de elementos: uma escala menor, como maquete, uma "normal" e outra maior, que impedem a leitura do objeto casa com a função de casa. Essa operação é o processo que Eisenman denomina Scaling, o qual consiste em isolar certas propriedades de um objeto e o justapor em um novo contexto em diferentes escalas. Rompe-se assim com a possibilidade de uma escala de referência, de uma realidade e sentidos fixos, uma vez que a proximidade entre as propriedades do objeto e o contexto permite a eclosão de novas e inesperadas relaçōes. 
Em 1985, Eisenman submete o projeto ao concurso para o IBA Housing, em Berlim, o qual Moneo chamou de uma neurose pessoal, um contexto artificial (YAMAMOTO, 2014, p. 80 e DAVIDSON, 2006b, p. 27). Visando contribuir para a reconstrução de região de Berlim, o Checkpoint Charlie, destruída durante a segunda guerra, a proposta de Eisenman sobrepóe o tecido urbano remanescente, fragmentado, a malhas da cidade histórica e à malha abstrata do plano de Mercator. Marca o entrelaçamento das malhas através de muros, procurando neutralizar nesse processo o muro de Berlim, o qual resta inserido junto de repetiçóes de muros com mesma altura oriundos de outras malhas. Com isso, essa barreira é destituída de sua conotação de divisora da cidade, através de novas relações formais, ou seja, o muro de Berlim torna-se apenas mais um muro das malhas do projeto. A partir deste exemplo do muro de Berlim, identificamos que o projeto não reproduz os sentidos, as representaçôes dadas, mas visa a minimizar o semântico em nome de relaçóes menos codificadas, permitir a emergência de novas informaçóes, novos sentidos.

O projeto Romeo e Julieta, de 1986, é referência no que diz respeito à operação de scaling. Vidler (1992) considera este projeto significativo; Moneo (2008) o destaca como o melhor deste período da produção do arquiteto e o mais próximo da desconstrução. Sobrepondo a cidade de Verona a marcas de locais simulados da história de Romeu e Julieta, além de misturar o existente, a história e a literatura, Eisenman busca afastar-se da presunção de que a arquitetura deve ser antropocêntrica, procurando formas mais complexas de sentido. Recusando ser puramente formalista, o projeto questiona a forma literal redutiva da arquitetura como representação da cultura; em outras palavras, questiona o modo como um elemento arquitetônico é visto como "opaco", presente e coincidente com seu sentido.

O Wexner Center for Visual Arts, de 1989, segue esta mesma discussão. Neste, o arquiteto lê a estrutura do campus, local do projeto, como uma primeira camada, a cidade no entorno como uma segunda e extrai uma terceira da estrutura da antiga instalaçáo militar que havia no local. Eisenman constrói, assim, uma torre-ruína dessa instalação, que não tem exatidão histórica, seja em formato, seja em localização; ela é apenas uma marca, a apresentação de relaçóes ao invés de representação de relaçôes. A proposta não é mímese ou representação dessas diferentes estruturas, mas traços delas, visando a tensionar o que se propóe com as outras estruturas, abrindo um conjunto de relaçóes possíveis entre elas. Essas estruturas não se apresentam desnudas, mas são mediadas pela intersecção entre o objeto, o arquiteto e o usuário.

Em 1988, é realizada no MoMA a exposição Deconstructivist Architecture. Nela, obras de Eisenman são expostas junto de trabalhos de Frank Gehry, Zaha Hadid, Rem Koolhaas, Daniel 
Libeskind, Bernard Tschumi e do grupo Coop Himmelblau. Esta exposição opera como marco, pois, diferentemente da Five Architects, que não conseguiu formar um conjunto, os nomes desta exposição são constantemente associados, e é consagrada a aproximação à filosofia da desconstrução de Jacques Derrida. Eisenman e Derrida se aproximam, dialogando diretamente, relação que chega ao auge quando Bernard Tschumi, ao ganhar o concurso para o Parc la Villette, em Paris, convida ambos para colaborarem em uma parte do projeto, o que resultou no projeto e texto Choral Work, ${ }^{2}$ mas também gerou tensão e o afastamento entre os dois. Parte dessa tensão está na troca de cartas em forma de texto, A Letter to Peter Eisenman, de Derrida (1990), e Post/El Cards: A Reply to Jacques Derrida, de Eisenman (1990), ambos publicados na Assemblage 12, de 1990. O afastamento entre Derrida e Eisenman ocorre a partir da discussão em torno da metafísica da presença e do conceito, exposto pelo filósofo, de Khôra, entendido por este como receptáculo, aquilo que permite o discurso. Derrida associa diretamente a arquitetura à estabilidade do sentido da metáfora, compreendendo que não há como existir uma casa que não é casa, que não carregue a ideia de abrigo. Eisenman, por sua vez, compreende que é possível retornar a um grau-zero da arquitetura, uma anarquitetura, momento anterior a qualquer sentido determinado, como o de abrigo ou de sustentação.

A participação em La Villette e a exposição no MoMA tornaram a década de 1980 importante período de visibilidade ao arquiteto. Apesar da fecundidade da década de 1970, a década de 1980 tornou-se, assim, o momento definitivo de consagração do arquiteto. Otilia Arantes (1993, p. 77) aponta com pesar o desentendimento entre Eisenman e Derrida como marco que impediu a formação de algo como uma internacional desconstrutivista, culminando no encerramento da segunda fase, na qual Eisenman abandona a ideia do scaling em nome do que denomina forma fraca. Como Stan Allen (2006, p. 62) denomina, trata-se de uma passagem das shifted grids (1970) ao scaling (1980) e, posteriormente, às folded surfaces (1990). Na década de 1990, o arquiteto buscaria outras referências, passando do local e do meio social das escavaçôes artificiais para referências diversas, provenientes de outras disciplinas, como a cadeia de DNA no Biocenter, de 1987, ou a fita de Moebius no Max Reinhardt Haus, de 1992. Seus desenvolvimentos sobre a forma o levariam também a outras aproximaçôes teóricas, como a aproximação à ideia de dobra (ou superfície dobrada), tal como utilizada no projeto para Rebstockpark Masterplan, de 1992, e na Igreja do Ano 2000, cuja nave é marcada pela ausência, pelo vazio entre as laterais construídas. Também passa a utilizar o auxílio de computação, como no AronoffCenter for Design and Art, de 1996, ou na Virtual House, de 1997, o que lhe permitiria estabelecer relaçôes mais complexas entre as formas e malhas.

2 Sobre a relação entre Eisenman e Derrida durante a colaboração do Choral Works, ver Kipinis (1998) 
Estas questôes permitem que associaçôes pautadas até então pela sobreposição de malhas tendam a relações topológicas da forma.

Mais do que tudo, durante a década de 1990, Eisenman associa a sua produção à noção de diagrama, possivelmente motivado pela arquitetura digital e seu uso do termo. Mesmo que desde o início de sua carreira seu método de análise possa ser caracterizado pela utilização de diagramas, como os de Colin Rowe, é o texto Diagram, an Original Scene of Writing (EISENMAN, 1998), de 1998, que inaugura este movimento de associação do termo à ideia de projeto por diagramas. Esse texto foi publicado na edição 23 da revista ANY, cujo título é Diagram Work: Data Mechanics for a Topological Age, significativo de qual alinhamento Eisenman buscava naquele momento. O livro Diagram Diaries (EISENMAN, 1999), de 1999, consolida este movimento, no qual o arquiteto relê sua trajetória a partir da ideia de que, durante sua carreira, ele sempre teria produzido pelo diagrama. A afirmação irá gerar polêmicas - Moneo (2008) discorda da tentativa de Eisenman de associar o início de sua carreira ao diagrama, restringindo o termo à década de 1990 em diante; já Gabriela Izar (2015) defende esta postura e estuda a série inicial de casas articuladas por esta ferramenta.

Foi nesta fase da carreira do arquiteto, em 1993, que se organizou a exposição de Eisenman no Museu de Arte de São Paulo Assis Chateaubriand (MASP), em São Paulo, momento fundamental de recepção de sua obra no país. Nela, foram apresentados quatro projetos do arquiteto: o Wexner Center for Visual Arts; o Biocenter; o Banyoles Olympic Hotel; e o Center for Arts, da Emory University, obras recentes do arquiteto à época e importantes para a discussão deste último período. No catálogo, produzido por Greg Lynn (MASP, 1993), seriam incluídos textos de Otilia Arantes e Sophia Teles, assim como o The End of the Classical: The End of the Beginning, the End of the End, de Eisenman. Além da inclusão de textos locais, é também interessante a inclusão do diagrama da cadeia de transformaçóes da House IV apresentado na exposição de 1988 no MoMA, única casa contemplada por imagem no catálogo.

Mais recentemente, em texto de 2008, Eisenman's Doubt, o arquiteto propóe ter ingressado em uma quarta fase desde os anos 2000. Novamente, a mudança de período vem associada a uma mudança de referente, visto que o arquiteto posiciona-se próximo às discussóes sobre autonomia, recuperadas por Pier Vittorio Aureli. Sinal desse interesse foi a entrevista que Eisenman concedeu a Aureli (AURELI; EISENMAN, 2013), publicada em 2013, A project is a lifelong thing: if you see it, you will only see it at the end, cujo título já indica um processo de autocrítica da própria carreira como um todo.

Ao fim da década de 1990 e início dos anos 2000, os empenhos de Eisenman em revisar sua 


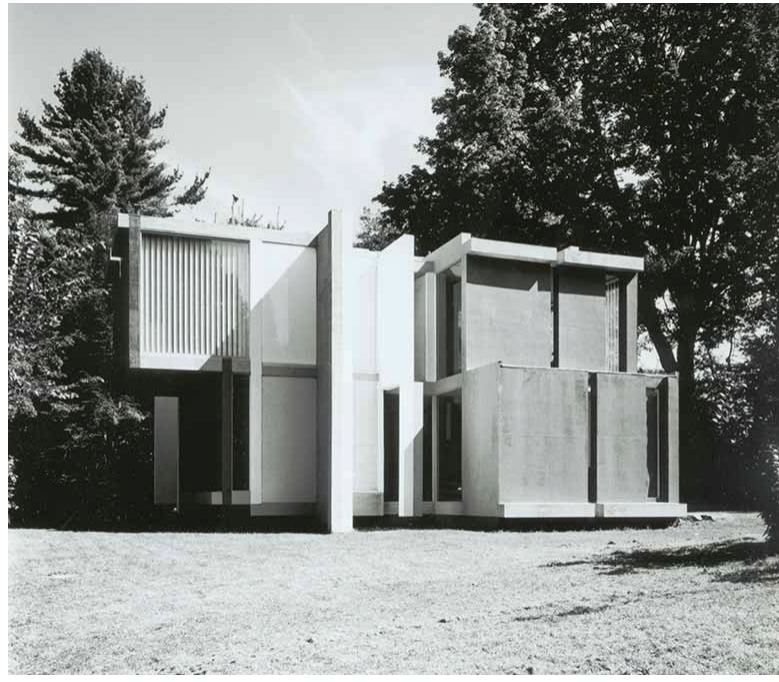

Figura 6 - House VI. Fonte: Site Eisenman Architects.

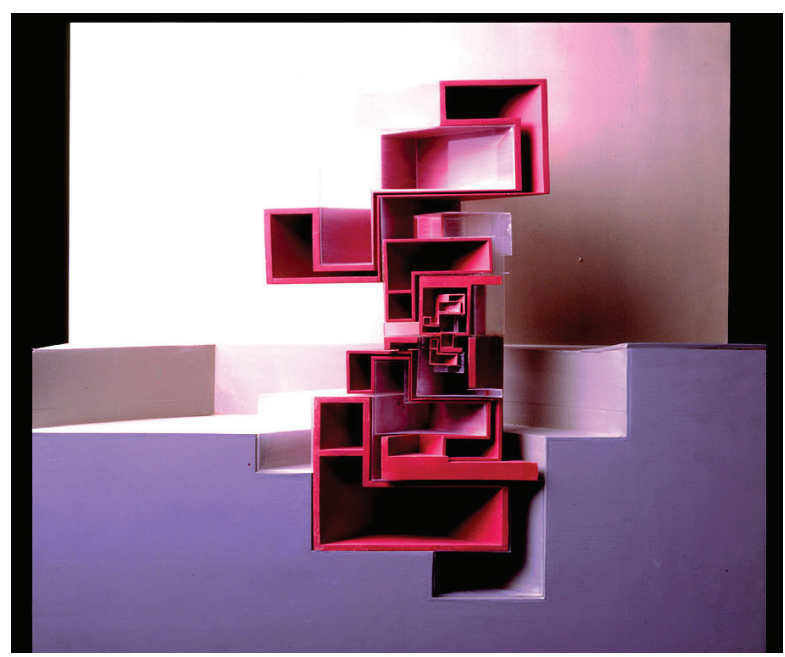

Figura 8 - Maquete House XIa no Cannaregio. Fonte: Site Eisenman Architects.

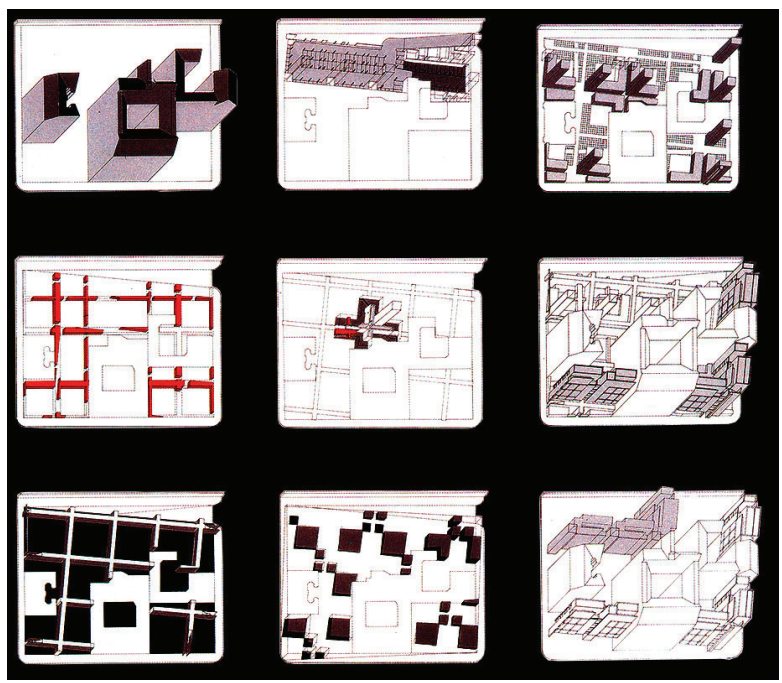

Figura 10 - Desenhos conceituais IBA Social Housing. Fonte: Site Eisenman Architects.

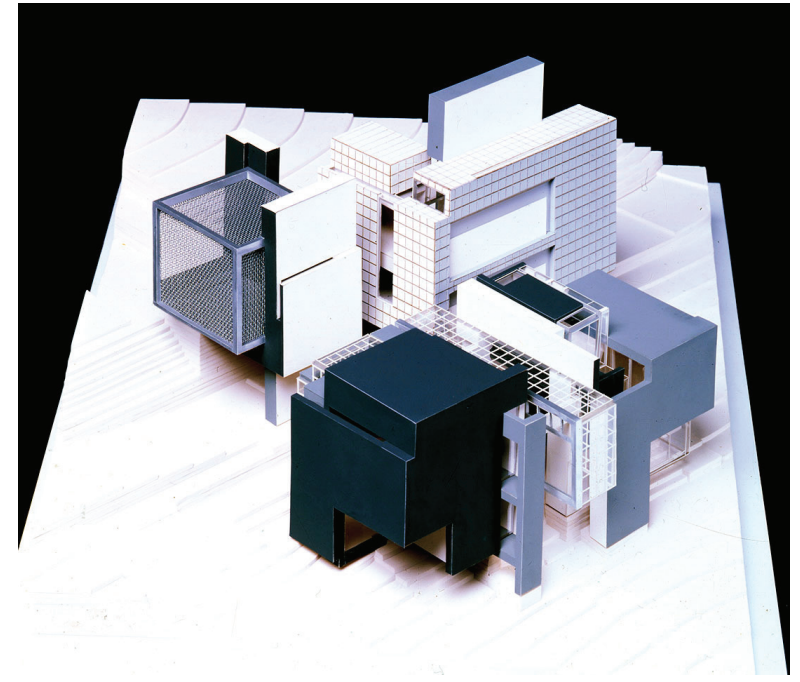

Figura 7 - maquete House X. Fonte: Site Eisenman Architects.

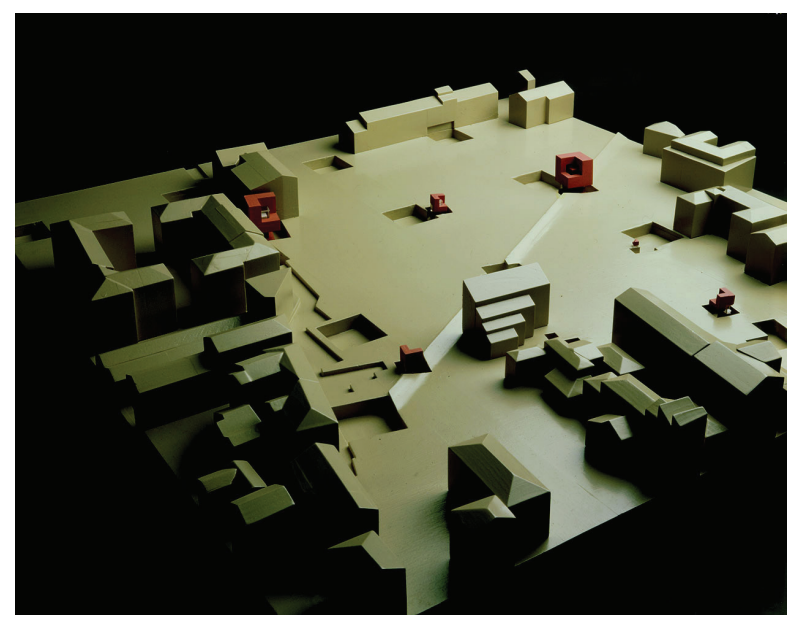

Figura 9 - Maquete Cannaregio. Fonte: Site Eisenman Architects.

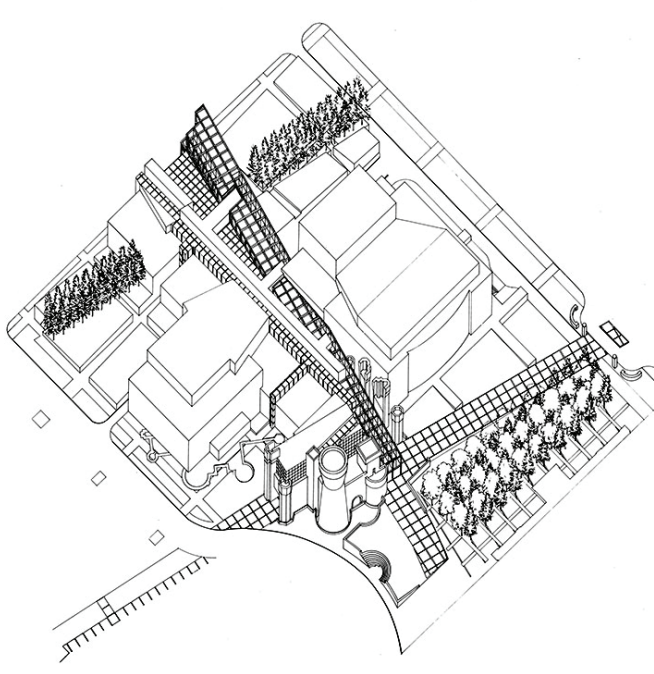

Figura 11 - Perspectiva Wexner Center. Fonte: Site Eisenman Architects. 
própria trajetória como uma unidade aumentam, com a publicação de livros como o citado Diagram Diaries (EISENMAN, 1999) e duas coletâneas de textos do próprio arquiteto, o Eisenman Inside Out (EISENMAN, 2004a), de 2004, e o Written into the Void (EISENMAN, 2007), de 2007; o primeiro compêndio traz introdução do próprio autor; o segundo, uma apresentação de Jeffrey Kipnis. O processo de autoanálise é tal que, nesse período, ele publica o fac-símile de sua Tese, The Formal Basis of Modern Architecture (EISENMAN, 2006c), em 2006, e, em 2008, uma entrevista discutindo suas viagens pela Europa com Colin Rowe durante sua estadia em Cambridge no início da década de 1960, Interview with Peter Eisenman: The Last Grand Tourist: Travels with Colin Rowe (EISENMAN, 2008b). As duas coletâneas de textos são fruto da curadoria do próprio arquiteto, estabelecendo o corpus por meio do qual ele pretende ser lido na esfera teórica. Exemplo disto considerando a parte mais relevante para esta dissertação - é a coletânea Eisenman Inside Out, que trata do início de sua carreira, mas exclui Dall'Oggetto alla Relazionalità e From Object to Relationship II, ou o Notes for a Conceptual Architecture II A, iniciando com os textos Towards an Understanding of Form e Notes for a Concetptual Architecture, além de seu texto para o Five Architects. Após estes três primeiros textos, o livro apresenta dois textos de leituras de outros arquitetos contemporâneos, e o sexto texto já é o Post-Functionalism. Adiante, quando analisarmos mais detidamente estes textos (Capítulo 2.3), perceberemos que a ausência deles condiciona fortemente a maneira como o período foi frequentemente interpretado.

Da década de 2000 aos dias de hoje, a produção do arquiteto vem sendo marcada por projetos de grande porte, como a Cidade da Cultura da Galícia, de 2011, e de cunho político, como o Memorial aos Judeus Assassinados da Europa, de 2005. Este último é uma série de volumes retangulares cinza, colocados lado a lado, sobre uma superfície ondulada. Projeto muito próximo a obras minimalistas, foi inicialmente desenvolvido junto com o artista Richard Serra, porém este saiu do projeto após conflitos com o arquiteto. Eisenman aceitava a condição de que o mar de volumes se encerraria no limite da quadra, enquanto Serra queria que ele se espraiasse além da área inicialmente prevista, rompendo o seu limite. Observamos a retomada de diferentes procedimentos por parte de Eisenman: a repetição de "cubos" como na primeira fase, mas condicionada à sobreposição de diferentes referências, como o local por meio do limite da quadra, como na segunda fase. Ao edificar apenas os volumes, o projeto define uma malha no espaço negativo entre eles, de forma a trazer a questão política do genocídio dos judeus durante a segunda guerra não por meio de um elemento semântico, representativo, mas por meio de uma ausência estrutural, sintática. Tal como o genocídio é uma cicatriz, uma ação que marcou a Europa com um vazio, a malha, o elemento regulador 


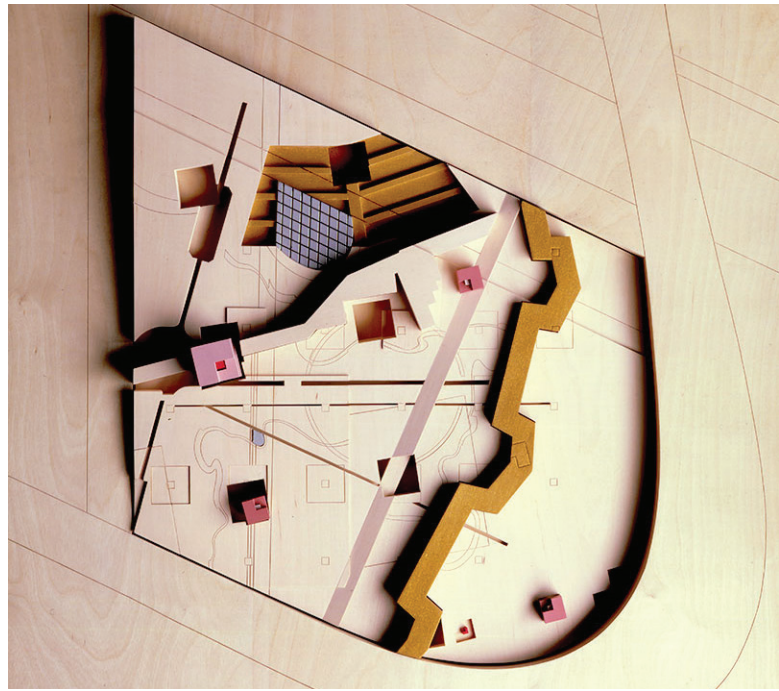

Figura 12 - Maquete La Villette. Fonte: Site Eisenman Architects.

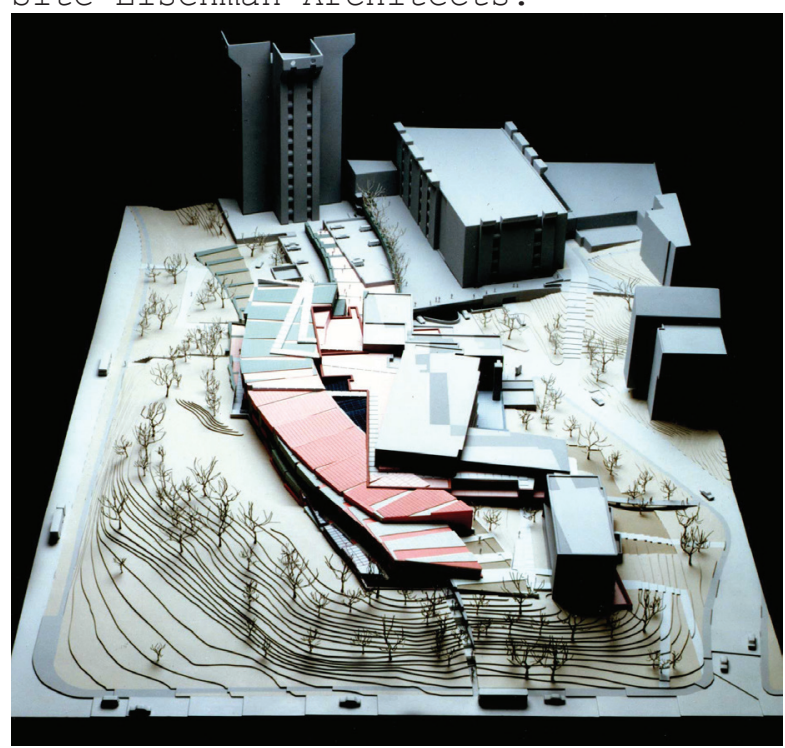

Figura 14 - Maquete Aronoff Center for Design and Arts. Fonte: Site Eisenman Architects.

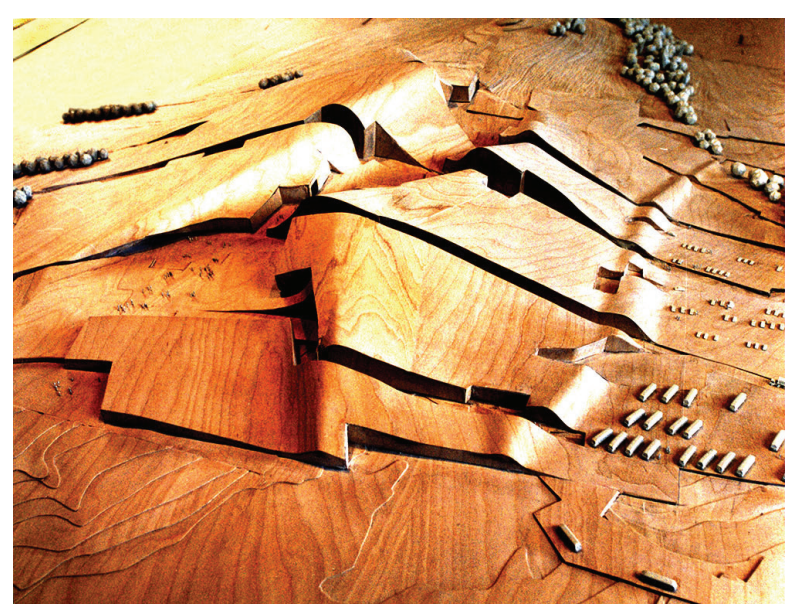

Figura 16 - Maquete CIdade da Cultura. Fonte: Site Eisenman Architects.

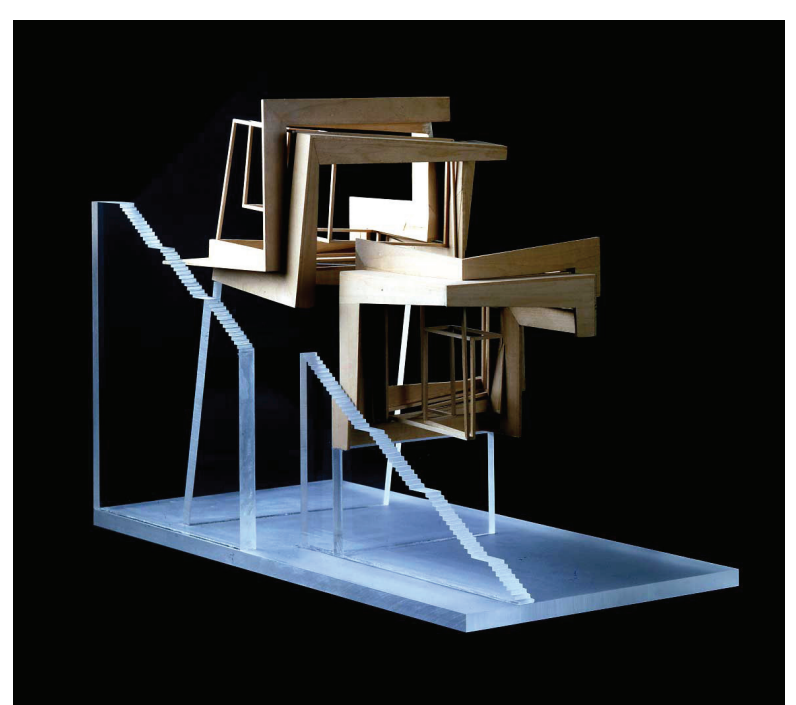

Figura 13 - Maquete Guardiola House. Fonte: Site Eisenman Architects.

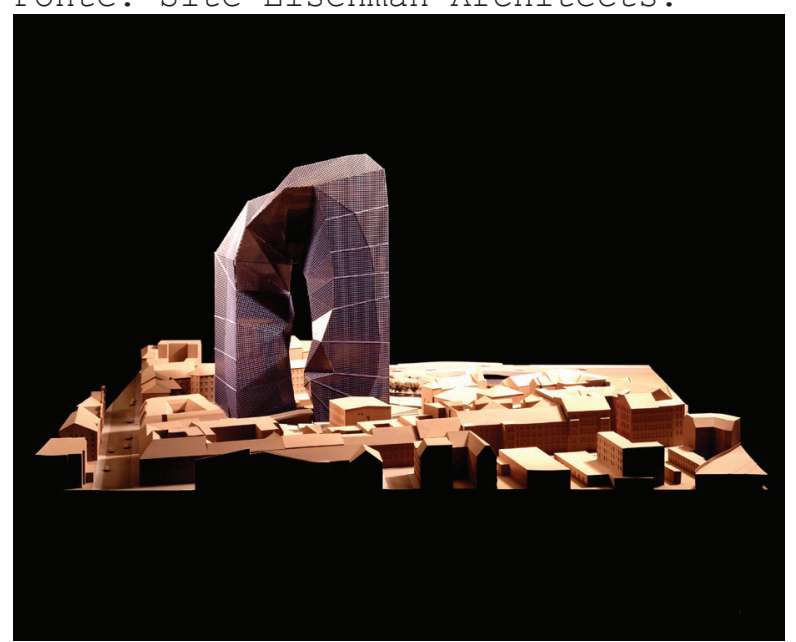

Figura 15 - Maquete Max Reinhardt Haus. Fonte: Site Eisenman Architects.

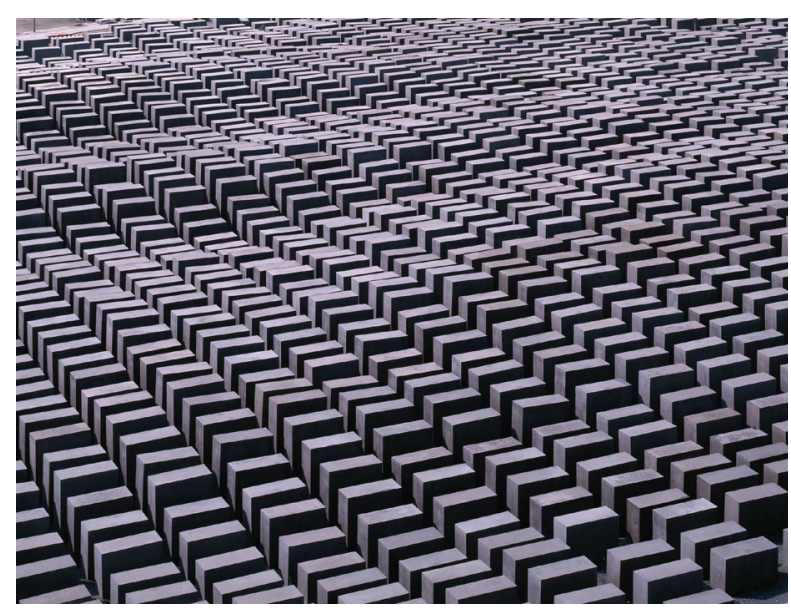

Figura 17 - Memorial aos Judeus Assassinados da Europa. Fonte: Site Eisenman Architects. 


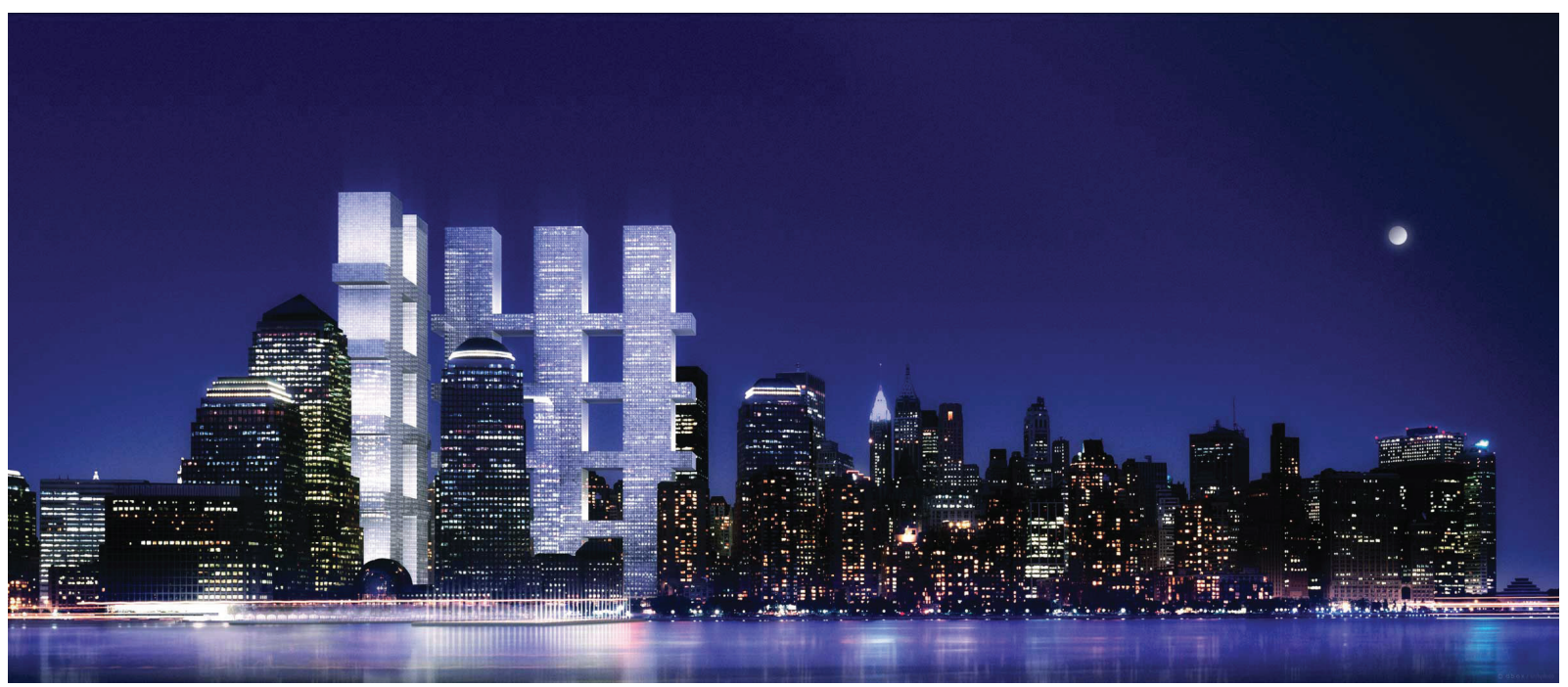

Figura 18 - Representação do Memorial Square World Trade Center.

Fonte: Site Eisenman Architects.

deste projeto, é uma ausência. Retomando o problema apresentado na introdução, de fato, o projeto apresenta dificuldade de veiculação de uma mensagem específica, como sugere a imagem em cartaz, justamente por seu potencial não ser representativo, mas analógico. Interessante colocar lado a lado esta malha ausente com a proposta de Eisenman para o Memorial Square, no World Trade Center, de 2002 - no local das duas torres destruídas, o projeto propóe duas malhas verticais marcando dois eixos e cujo interstício é vazado. No vazio, Eisenman marca no piso uma terceira malha. Comparantdo esta malha com a do Memorial aos Judeus Assassinados da Europa percebemos que possuem relações figura/fundo opostas Mesmo com operação inversa, também podemos ver, no Memorial Square, Eisenman remetendo a uma questão política por meio de relaçóes da forma. Em um local de vazio, de destruição, o arquiteto propóe malhas nos três eixos, uma presença de referência para uma reconstrução.

\subsection{Linhas de absorção}

O projeto da House I apresenta condição incomum de recepção, pois o material utilizado tanto por Eisenman quanto por outros autores remete principalmente a uma fonte: os desenhos e texto deste projeto presente no livro Five Architects (EISENMAN et al., 1975), de 1975. Fruto do sétimo CASE (Conference of Architects for the Study of the Environment), de 1969, Eisenman apresenta neste os projetos da House I e da House II, ambos com imagens e desenhos acompanhados de textos do próprio arquiteto. Outros meios pelos quais Eisenman posteriormente apresenta este projeto - o site do arquiteto e o livro Diagram Diaries (EISENMAN, 1999) - reproduzem as mesmas imagens. 

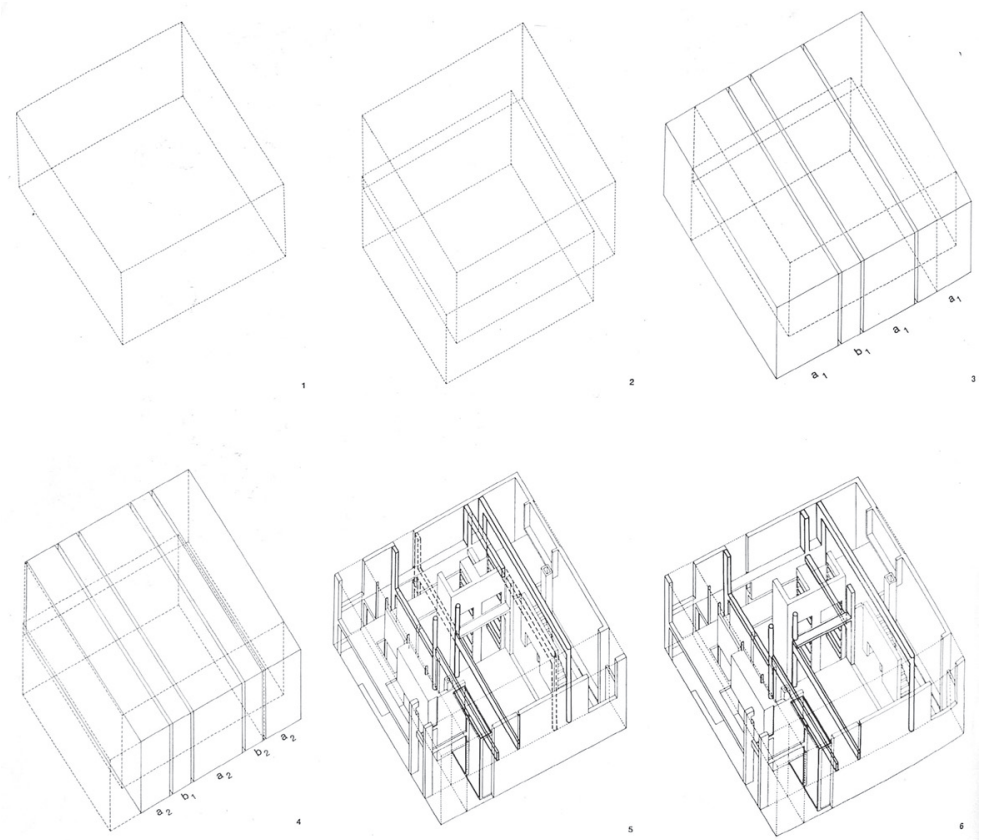

Figura 19 - Perspectivas isométricas conceituais da House I apresentadas no livro Five Architects. Fonte: EISENMAN et al (1975, p.22).
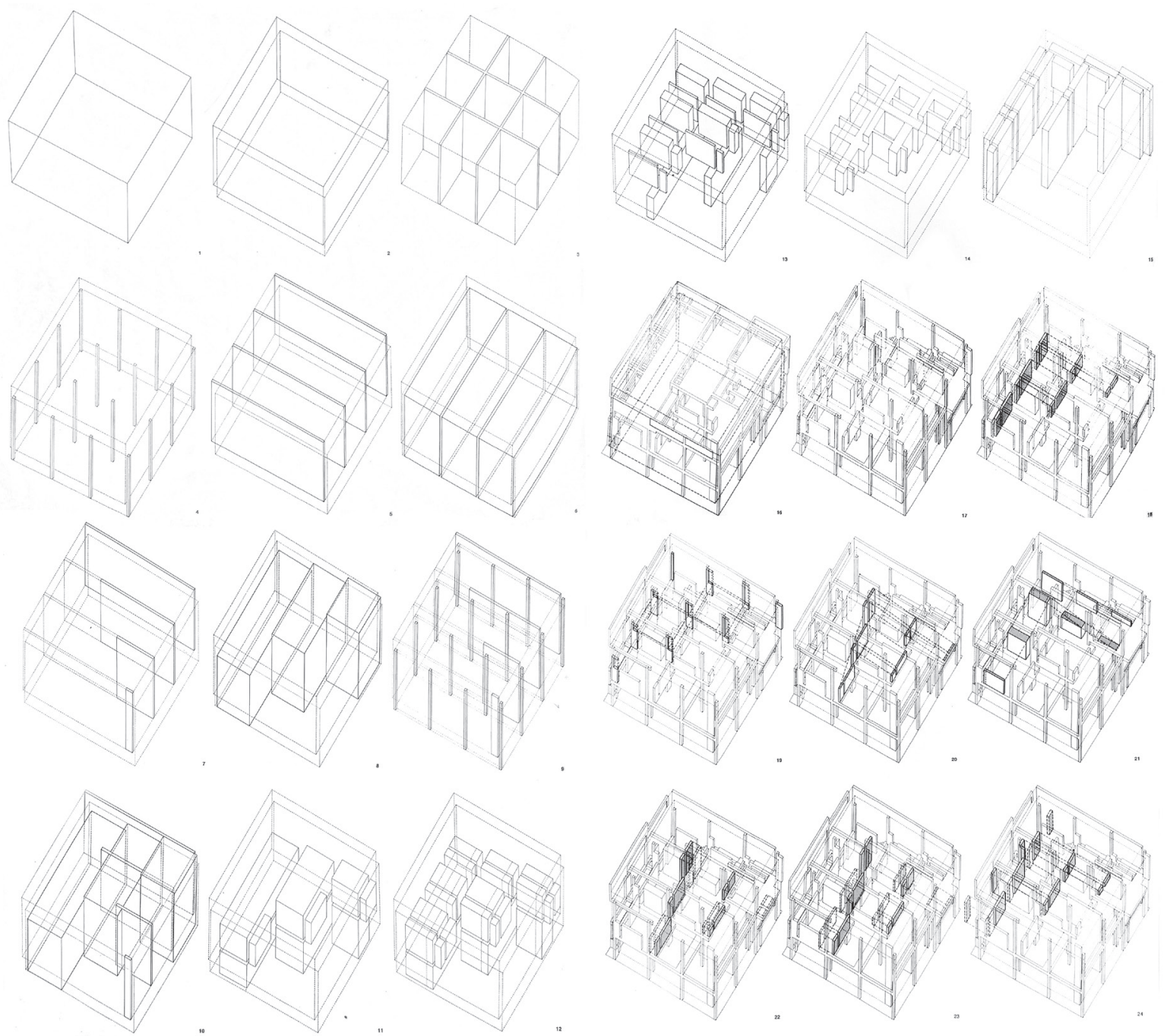

Figura 20 - Perspectivas isométricas conceituais da House II apresentadas no livro Five Architects. Fonte: EISENMAN et al (1975, p.32-35). 
O livro Tracing Eisenman (DAVIDSON, 2006a), publicação organizada por Cynthia Davidson, que pretende ser suas "obras completas", traz pequenos trechos de Eisenman sobre os projetos apresentados, e nele a House I vem acompanhada de imagens e trechos de texto reproduzidos do Five Architects.

Neste texto, Eisenman apresenta a forma da House I como fruto de um deslocamento diagonal entre dois quadrados. Condizente com a sua posição da fase das Transformaçôes, o arquiteto situa a diagonal como a "estrutura profunda" do projeto, e sua "estrutura aparente", as formas, seria o reflexo de duas estruturas, uma definida pelos planos; e outra, pelos volumes. Quanto às imagens, a publicação do Five Architects traz três pares de desenhos da House I: o deslocamento da diagonal, as sequências de planos e a diagonal em isométrica. Comparando este conjunto com os desenhos apresentados da House II na mesma publicação, encontramos discrepância no material apresentado das duas casas - o material da House II apresenta sequência de diagramas, as operaçóes de transformação da forma são metodicamente analisadas com uma sequência de vinte e quatro isométricas. Esta apresentação detalhada é mais condizente com a ideia de sequência de transformaçôes da estrutura profunda, semelhante à que se apresenta posteriormente da House IV, por exemplo. Por outro lado, o material da House I é de conexão difícil: o que na House II aparece como um "passo a passo", na House I é lacunar, omitindo-se etapas.

É possível inferir que neste momento, em 1969, a House II é o projeto mais alinhado ao pensamento de Eisenman em torno das Transformaçóes, incluindo-se arbitrariamente a House I nesta concepção ${ }^{3}$; outro indício da fragilidade da apresentação do projeto da House I é que as isométricas 3 e 4 apresentam distorção em publicações posteriores. Como veremos adiante, estas isométricas apresentam sequências de volumes, das quais se apreende pelo texto de Eisenman que o par A1-B1 coincide entre ambas as imagens (EISENMAN et al., 1975, p. 17). Em publicações posteriores, como na reedição deste texto presente na coletânea Eisenman Inside Out, as indicaçôes da sequência estão deslocadas, impedindo essa coincidência e dificultando a leitura. As plantas e elevações da House I presentes no Five Architects são também as imagens consagradas deste projeto.

Diferentes estudiosos da obra de Eisenman trabalham com distintos recortes e olhares para a produção do arquiteto, resultando, por vezes, em perspectivas incongruentes e até opostas. Podemos

3 Hipótese plausível dentro do desenvolvimento de Eisenman. Como poderemos ver adiante (Capítulo 2.3), é uma questão de o arquiteto retomar leituras de forma crítica, encontrando novas relações. Seu trabalho não está isento dessas retomadas. Como principal exemplo, temos o livro Diagram Diaries (EISENMAN, 1999), no qual procura articular toda sua carreira até então pela noção do diagrama. Quanto a esta relação na série de casas, é interessante a leitura de Gabriela Izar (2015, p.298), que aponta a conexão entre elas. A leitura de uma casa após o projeto é ponto de partida à próxima. 
ligar isso tanto à vasta carreira do arquiteto, como a sua própria trajetória, as quais atravessam diferentes fases e projetos teóricos; na própria produção do arquiteto sobre sua obra, verificamse mudanças de ponto de vista. Entre Cardboard Architecture (EISENMAN, 1973a), House X (EISENMAN, 1983) e Diagram Diaries (EISENMAN, 1999), o discurso do arquiteto se altera: como vimos, ao descrever a série de casas durante o desenvolvimento dos projetos, ele reconhece diferenças internas entre uma e outra, contudo, conforme sua carreira avança, essas são aliviadas em nome de uma visão do conjunto.

A recepção dos diferentes projetos de Eisenman, portanto, varia de autor para autor. A House I, não é exceção. Sua apresentação por Rafael Moneo (2008) em Inquietação Teórica e Prática Projetual fornece-nos uma síntese dos principais pontos levantados sobre o projeto - Moneo identifica uma forte influência de Terragni sobre o arquiteto, em sua tentativa de remover a carga semântica dos elementos arquitetônicos e no aspecto de frontalidade do projeto, articulado a partir da fachada. $\mathrm{O}$ autor destaca ainda como fato gerador da forma o início do processo de transformaçáo do cubo em um deslocamento "hipotético e abstrato". Moneo não especifica esse deslocamento, mas toma como referência a diagonal apresentada no texto de Five Architects. Leituras mais panorâmicas, como as de Charles Jencks (1989) e Josep Maria Montaner (1999 e 2001), ressoam alguns desses elementos, particularmente a dívida com o modernismo, por meio de Le Corbusier e Terragni, e o recurso à abstração formal, com o afastamento do campo semântico em favor do projeto como produto de processo formal autônomo.

Stan Allen (2006) e Michael Hays (2009), por outro lado, tocam na questão da House I ensejar um divórcio entre a forma e a materialidade por meio do recurso de apresentaçáo do processo na forma, aproximando o edifício de sua representação, a maquete. Michael Hays relaciona esse afastamento da materialidade com a proposta de autonomia de Eisenman. Seu processo de remover as camadas do projeto que não sejam arquitetônicas, seus significados, conduziria a um afastamento do meio, resultando em uma forma sobre a forma, isto é, uma forma autorreferente. Otilia Arantes (1993) aprofunda a questão ao reconhecer uma diferença a partir da House $I V$, na qual o projeto representaria seu próprio processo, além de considerar a House I e a House II como tematizaçóes da natureza do signo. Parafraseando o Magritte de Foucault, Otilia coloca que: "o edifício representa a representação sobre a folha de papel.” (ARANTES, 1993, p. 80-82). A primeira casa seria construída não como edifício, mas como uma maquete em tamanho real, comparável a um modelo de avião, já a segunda se esforçaria para não se realizar, enquanto representação do modelo. Como eles, também Robert Somol (1999) assinala o vínculo da House I com o conjunto de projetos pautados pela noção 44 
de arquitetura conceitual e estrutura profunda, alinhando-se à ideia da série.

É sensível a influência do texto de Five Architects na recepção do projeto da House I como integrante da fase das Transformaçôes, associando-a às questóes colocadas pela House II em detrimento de seu nexo com as discussóes da Tese de Einseman, por exemplo; outro sintoma desta situação da House I é a recorrência de autores que privilegiam a House II como principal projeto deste período. Moneo (2008), aliás, considera a House II o melhor projeto da série de casas, e Cynthia Davidson (2006c), na introdução de Tracing Eisenman, elenca este mesmo projeto como ponto de partida para a exploração dos vazios nos demais projetos de Eisenman. Otilia Arantes, por sua vez, lembra que na exposição de 1985, "Os Imateriais", no Beaubourg, foram apenas expostas as House II, X e XIa, excluindo-se da mostra o primeiro projeto da série (ARANTES, 1993, p. 76).

Há autores que ampliam a percepção da House I para além de sua associação com as Transformaçóes e a proximidade com a House II. Gabriela Izar, em sua tese Diagramática: descrição e criação das formas na arquitetura seriada de Peter Eisenman (IZAR, 2015), diferencia-se dos demais autores - ao procurar compreender o conjunto inicial de projetos de Eisenman, a série de casas da House I a House X, como um conjunto articulado pelo uso do diagrama, a autora retoma a Tese de Eisenman e procede a busca de material no acervo do escritório do arquiteto, conservado pelo Canadian Centre for Architecture. Com isso, ela traz referências diferentes para a leitura da House Iapresenta, por exemplo, que o programa original do projeto era o estabelecimento de um museu de brinquedos como anexo a uma casa pré-existente em terreno de subúrbio, além de analisar elementos de sua materialidade até então pouco considerados, como sua "estrutura de madeira e paredes de estuco" que é o modo de edificar a casa como uma caixa de papeláo cortada por planos. Por meio da pesquisa no acervo, ela destaca também que a casa foi projetada em um sítio caracterizado, ou seja, a autora situa a pré-existência, a residência para a qual essa edificação é anexo. Em relação à gênese do projeto, utiliza o mesmo texto de Eisenman presente no livro Five Architects, portanto, não coloca em cheque o deslocamento "hipotético e abstrato" na diagonal.

A utilização da Tese de Eisenman (EISENMAN, 2006c), na pesquisa de Gabriela Izar se destaca, pois, em geral, a recepção deste trabalho do arquiteto é pouco usual. Apresentada em 1963, a Tese só viria a adquirir ampla circulação a partir de 2006, com a publicação de uma edição fac-similar. Em pós-escrito nesta publicação, o próprio Eisenman reconheceu a pouca circulação deste material até então e vê com certo interesse a sua ausência nas análises de sua obra: “Talvez, agora, a história possa superar as falhas da escrita e as ideias pouco amadurecidas de modo a revelar o valor desse trabalho de juventude em minha carreira mais recente" (EISENMAN, 2006c, p. 381, tradução 
nossa). Na introdução de seus Diagram Diaries, de 1999, no qual o arquiteto procura articular sua carreira em torno da ideia de diagrama, Robert Somol também assinalou esta ausência, pontuando o livro como a introdução para uma tese ausente: "um prefácio post facto a uma dissertação nunca publicada, ainda que um prefácio que agora se remete a (e é demonstrada por) um amplo corpo de trabalho que se impóe." (SOMOL, 1999, p. 7, tradução nossa). Trata-se de uma omissão revertida apenas em trabalhos recentes, alinhada à proposta atual de Eisenman de contemplar sua própria carreira como um todo, relendo seu ponto de partida. O trabalho de Izar, por exemplo, defende que é possível compreender a série de casas de Einseman como conjunto de projetos a partir do uso do diagrama. Retomando a Tese para associar o diagrama como método utilizado por Eisenman já antes da House I, presente em suas leituras de projetos modernos apresentadas na Tese, ela alinha o trabalho de juventude ao seu Diagram Diaries, compreendendo em seu interior a série de casas nesta mesma perspectiva.

Anthony Vidler ${ }^{4}$ situa a House I em outra perspectiva em relação à série de casas. Em seu livro Architectural Uncanny, além de destacar que a série de casas não é uma sequência temporal simples, mas a exploração de um conjunto variado de questóes, ele define a House I como um projeto que inagura diferentes questóes. “[...] Quando a Fin d'Ou T Hou S é justaposta a qualquer outro projeto na série de casas, ou, de maneira ainda mais perturbadora, com, digamos, a House I, o 'começo' da linha, nos deparamos com uma diferença que, no entanto, parece o mesmo." (VIDLER, 1992, p. 119, tradução nossa) Vidler reconhece, portanto, certa instabilidade na ideia de série, apontando que há diferenças entre as primeiras casas, onde se identifica um desenvolvimento linear da forma ao longo dos anos, e os projetos da House VI em diante, nos quais verifica-se uma exploração mais aberta.

Texto de Guido Zuliani (2006), Evidences of Things Unseen, traz tanto a House I quanto a Tese como elementos importantes na gênese da obra de Eisenman. Nele, o autor aponta a fonte da única imagem de ampla circulação da House I, não apresentada no livro Five Architects: a publicação House of Cards, de 1989, que situa o desenho em 1968-9. O autor, contudo, levanta a possibilidade de a data não ser correta, questionando a razão de ter sido publicado tão mais tarde. Supóe que isso pode ser consequência de ter sido elaborado por Eisenman posteriormente ao projeto da House I (ZULIANI, 2006, p. 322). Zuliani encontra neste desenho da House I uma progressão em escalas que se move de "forma cinemática", característica atribuída à House $I V$, e diagramas que sugerem

4 Vidler é referência importante, pois estudava em Cambridge enquanto Eisenman escrevia sua Tese, recebendo menção do arquiteto em seus agradecimentos pelo auxílio com imagens e notas do texto (EISENMAN, 2006c). 
o "sistema de ordenamento presente em projetos como a House VP" (ZULIANI, 2006, p. 323, tradução nossa). Além disso, o autor mostra a operatividade destes desenhos, indicando que os diagramas apresentados não carregam conteúdo semântico, mas levam a uma arquitetura fechada sobre si mesma: como no processo das Transformaçóes, a referência destes diagramas é a própria disciplina. As sequências A-B-A-B-A são referências diretas a Rowe (leitor de seu orientador Rudolf Wittkower), o qual lê em diagramas as sequências A-B-C-B-A de Palladio. Diferença importante entre Eisenman e Rowe é que, na House I, o arquiteto trabalha as paredes não como apenas linhas da malha do diagrama, mas também como volumes, são planos com espessura, como veremos adiante.

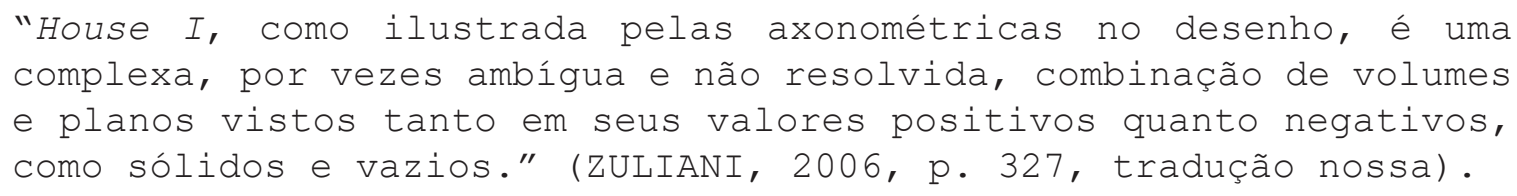

Zuliani associa este modo de compreender as formas a partir de volumes ao que Eisenman formula em sua Tese, ampliando a recepçáo do texto do arquiteto ao acrescentar que a negligência em relação a ela não deriva apenas de sua pequena circulação, mas de ter sido apressadamente considerado um trabalho muito próximo ao de Rowe e Wittkower, como se apenas posteriormente o arquiteto houvesse sido capaz de romper com a linha de pensamento de Rowe. O autor defende que, na Tese, Eisenman já questiona Rowe: se o mentor estava em busca de seu ideal de forma, de uma "matemática da villa ideal", o discípulo buscava compreender o modo como a forma operava sem determinar um fim. Em vez de uma referência ideal, Eisenman interessa-se pelo processo de ordenamento da forma, aproximando-se, desse modo, de Panofsky, em sua busca por uma autonomia da obra de arte em relação a determinaçóes externas de sentido ou de natureza psicológica do produtor. Neste sentido, Zuliani apresenta uma série de questóes relevantes presentes tanto na Tese do arquiteto como em sua carreira: o postulado da arquitetura pautada pela lógica da forma, a autonomia pelo recorte da forma em relação a elementos externos, o uso de pares de conceitos e a maneira como lê outros arquitetos, a despeito do que eles mesmos dizem de suas obras.

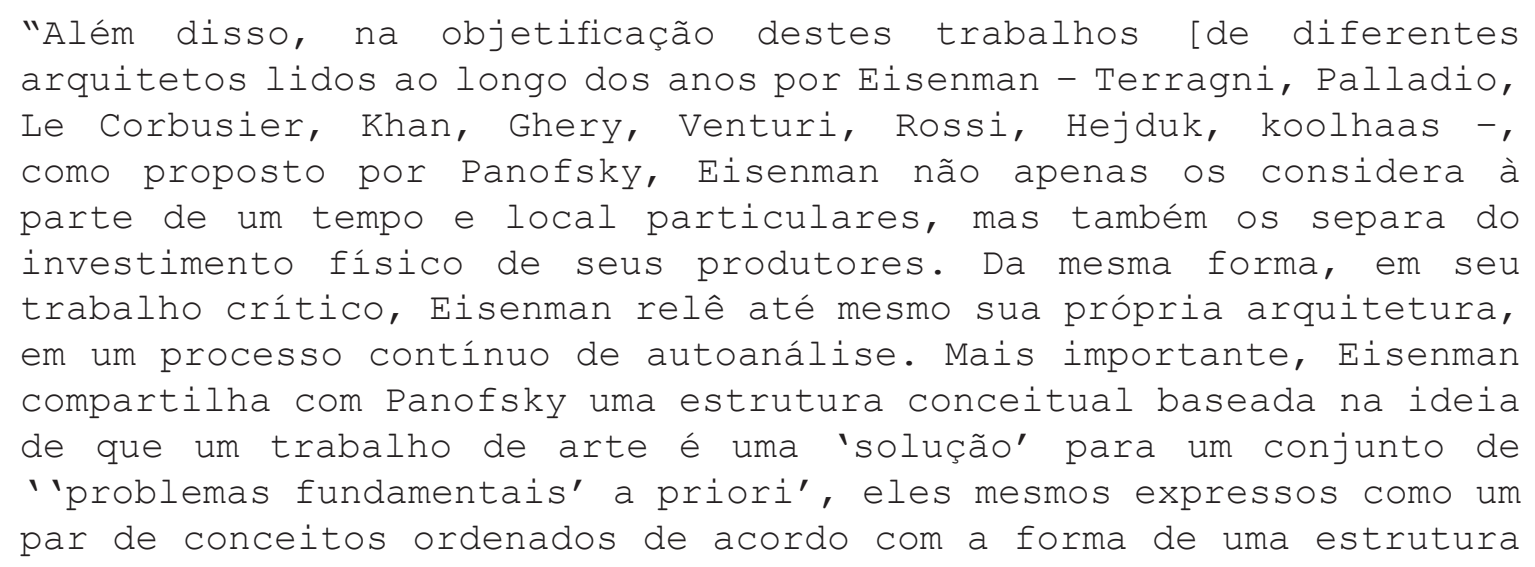


antitética, a qual Panofsky assume como 'os conceitos fundamentais de uma teoria da arte'. Dentre os pares que Panofsky propôs [...] há uma 'tendência longitudinal' e uma 'tendência à centralização', as quais correspondem aos 'a priori' de Eisenman de formações 'lineares' e 'centroides'." (ZULIANI, 2006, p. 335-336., tradução nossa)

É nesta linha que, nos capítulos que se seguem, analisaremos a Tese The Formal Basis of Modern Architecture (EISENMAN, 2006c) e a House I, como momentos de articulação do pensamento de Eisenman, os quais se distinguem dos projetos seguintes, introduzindo questôes que dialogam com projetos posteriores do arquiteto. A proposta é retomar pontos de sua carreira tendo em vista o percurso por ele traçado até o presente, reconhecendo na Tese e na House I não só conexões recíprocas e com a sequência de projetos do período, mas também chaves de compreensão mais abrangentes acerca do conjunto de sua obra. 
0

$\mapsto$

EI

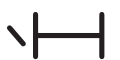

$\Omega_{1}$

U

$\sum_{\text {省 }}^{\text {至 }}$

U

$\mapsto$

[I]

N 


\subsection{Ordem Total: as bases formais da arquitetura moderna}

Em 1963, Peter Eisenman apresenta sua Tese, The Formal Basis of Modern Architecture, (EISENMAN, 2006c) em Cambridge. Neste trabalho, o arquiteto defende que a arquitetura é um processo lógico de desenvolvimento da forma, cujas regras internas têm predominância sobre questôes funcionais ou históricas. A Tese é dividida em quatro momentos. No primeiro, Eisenman justifica a lógica da forma como o principal elemento da arquitetura, traçando crítica ao movimento moderno e comparando seu empenho ao de outros autores. Em seguida, o autor explora a base conceitual para o desenvolvimento de seu sistema formal, expondo o binômio genérico-específico que veremos adiante. Na terceira parte, Eisenman, a partir de sua fundamentaçâo conceitual, explora como são desenvolvidos os sistemas formais e seu método de análise da forma. Por fim, o arquiteto aplica seus conceitos na análise de oito projetos modernos, demonstrando a validade de seu sistema, e amplia o repertório formal iniciado na parte anterior. $\mathrm{Na}$ Tese, encontramos características importantes que percorrem a carreira do arquiteto: o uso do diagrama, a compreensão da arquitetura a partir de relaçóes formais e como processo racional de apreensão conceitual, a instabilidade de sentido, o uso da ambiguidade e a proposta de teoria aberta.

Eisenman procura elaborar neste trabalho sistema formal que seja uma teoria aberta, que discute o como desenvolver a forma sem determinar o fim; em oposição à teoria aberta, estão as teorias fechadas. Estas propóem o que deve ser projeto de arquitetura, o fim, restando apenas explorar o como, sendo considerada por Eisenman como limitantes. $\mathrm{O}$ arquiteto compreende a arquitetura moderna como formação que data do Renascimento e que sempre operou por teorias fechadas.

$\mathrm{O}$ arquiteto relaciona-se com o passado recente buscando reabilitar o projeto moderno ${ }^{1}$. Ele reconhece falha no movimento moderno, o qual, ao procurar se identificar com mudança, tornouse representação da ideia de mudança. Ademais, a concepção moderna de "revolução permanente" é uma especulação de caráter histórico. Em vez de prosseguir nesta ênfase na história ou em questôes da técnica e da tecnologia, ${ }^{2}$ Eisenman procura reavivar a teoria, a crítica de arquitetura. É

1 Eisenman explicita que as premissas de sua Tese surgem da discussão de Le Corbusier sobre a forma. Sua principal referência são as "Quatro composições" do arquiteto: a primeira é massa; a segunda, massa ou superfície, dependendo do tratamento específico que se daria ao volume; a terceira, uma massa específica em relação a um grid absoluto; e a quarta é exemplo da dialética massa-superfície, "[...] apresenta a clássica ambiguidade figura-fundo" (EISENMAN, 2006c, p. 107-109, tradução nossa).

2 Como forma de tipificar estas outras posturas, Eisenman cita Reyner Banham e John Summerson. Banham é exemplo de crítica moderna. Preocupado com a ideia de mudança acaba por colocar-se em um ponto de vista historicista. Antes de ser uma mudança ou ser uma arquitetura da máquina, passa a ser a representação de mudança ou da máquina. Summerson propõe como alternativa à análise de cunho histórico a compreensão pelo programa. Solução que Eisenman identifica como insuficiente, uma vez que o programa guarda fortes relações com a esfera social, portanto, esfera externa à disciplina arquitetura, além de ser uma solução que culmina no 
importante salientar, porém, que Eisenman não tenta eliminar a componente histórica ou semântica da arquitetura, mas, sim, resgatar a crítica frente à negligência que identifica.

$\mathrm{Na}$ Tese, o autor sugere que suas questôes são de ordem conceitual, propondo a existência de um sistema de relaçóes formais inerentes a toda e qualquer arquitetura (EISENMAN, 2006c, p. 17). Tal sistema seria autônomo em relação a esferas externas à arquitetura; independentes de época ou estilo, as formas arquitetônicas seriam resultado de linguagens que derivam da essência formal e do que o arquiteto ora denomina "ordem total", ora "ambiente total". O propósito desse sistema seria transmitir as relações formais, o conceito, isto é, as características da forma em seu estado genérico, em uma palavra, sua ordem total. Eisenman procura o que é próprio da arquitetura, a lógica inerente às formas, algo que não depende da subjetividade do arquiteto ou do espectador, algo afastado do papel de representação. Prosseguindo a partir da abstração moderna, busca deslocar o semântico através de formas geométricas:

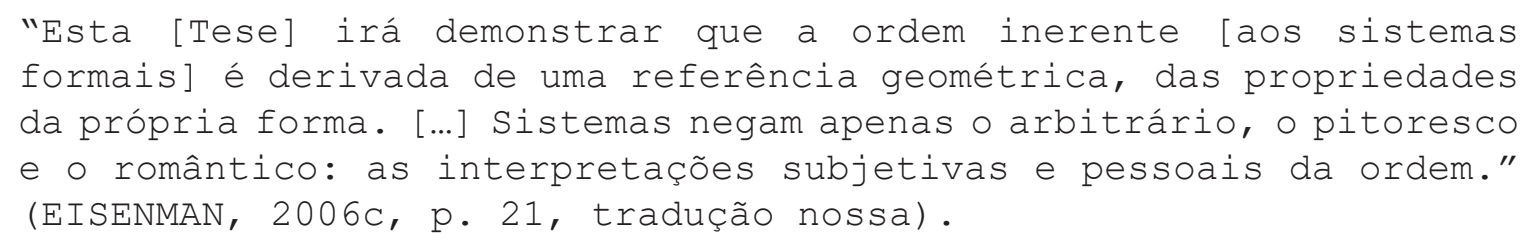

Imersos em um meio social e tecnológico distendido, o indivíduo não consegue apreender uma ordem; desamparada, a arquitetura refugia-se em maneirismos e na autoexpressão, "uma ênfase compulsiva na criação isolada que não diz respeito à ordem total.” (EISENMAN, 2006c, p. 29, tradução nossa) ${ }^{3}$; esses maneirismos são uma forma ainda suspirante da utopia moderna. Para destacar o papel da forma, Eisenman subdivide a arquitetura em categorias: o conceito ou intenção, a função, a estrutura, a técnica e a forma, ordenando-as de forma lógica, a partir do que é genérico, ou seja, da ordem total. O projeto é uma intervenção específica em um ambiente genérico. Para que a arquitetura forneça clareza ao indivíduo, permitindo que ele apreenda a ordem do ambiente, ela não pode atender a uma demanda pontual. Distinto do ambiente genérico, o ambiente construído é relativo a um determinado estado, não abarca aquilo que o ambiente virá a ser. No entanto, uma visão de um futuro específico, uma utopia, como propõe o moderno, também é relativa ${ }^{4}$.

"Uma aproximação racional a isto [o problema da forma] deve predicar

a ordem total - ou, em termos desta tese, um absoluto que é capaz de abranger mudanca e crescimento enquanto mantém sua característica tipo, categoria que Eisenman considera fechada, pois determina um como, e histórica, visto que o tipo viria da função utilitária, a qual varia com o tempo.

3 Quanto a essa questão de necessidade de clareza que coloca em primazia o genérico, ver EISENMAN (1963, p. 458).

4 Eisenman critica especificamente o futurismo de Sant'Elia. Sua "Città Nuova", por mais que enseje absolutos como as noções de energia e velocidade, seria composta por edifícios que visam a um estado futuro fixo, portanto, relativo (EISENMAN, 2006c, p. 31 e EISENMAN, 1963, p. 458). 
como um absoluto. É o conceito da prioridade de um absoluto desta natureza que é crítico aqui, uma vez que ele sozinho pode nos prover as bases para uma ordenação hierárquica dos cinco elementos." (EISENMAN, 2006c, p. 5, tradução nossa).

Importante, neste trecho, é a descrição da ordem total como um absoluto, uma constante que abarca a mudança. É uma definição próxima à do ser platônico ou à do espaço cartesiano infinito e indistinguível. Diferente do meio tecnológico e social distendido, de mudança constante que desorienta o indivíduo, esse absoluto proposto por Eisenman, também denominado genérico, mantém a compreensibilidade e a ordem do ambiente. É a ordem total, portanto, a situação menos condicionada a questóes transitórias, específicas.

Como Eisenman compreende que a arquitetura é, em essência, dar forma aos demais elementos, dar compreensão ao ambiente, ela é o elemento primeiro. A hierarquia entre intenção, função, estrutura e técnica segue do que é genérico ao que é específico. Intenção é a concepção inicial daquilo que será projetado, remete a algo transcendental 5 , assim, difere-se da função histórica, que varia conforme o tempo - a função de templo, por exemplo, difere entre gregos e católicos da Idade Média. A função abarca tanto o uso, função utilitária, quanto o sentido, função simbólica. Esta última distingue-se da intenção, pois a intenção é o conceito, enquanto a função simbólica é a representação de algo como um conceito (EISENMAN, 2006c, p. 43-45). Abaixo da função, técnica e estrutura estão no fim da hierarquia, são os que remetem mais diretamente à materialização, estando mais distantes do genérico e mais próximos ao específico.

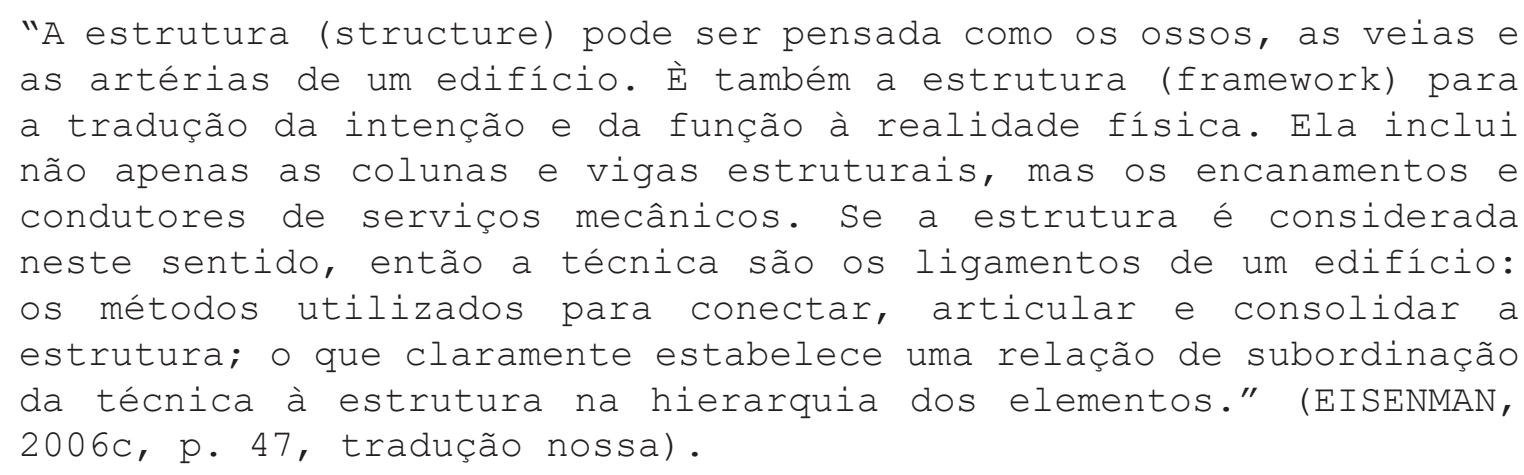

Ou seja, o ordenamento dos elementos proposto pelo arquiteto vai do mais genérico, abstrato, ao que está mais próximo ao específico, material, resultando na hierarquia: forma, intenção, função, estrutura e técnica. ${ }^{6}$

5 Eisenman cita como exemplo de intenção o "espírito da época" (EISENMAN, 1963, p. 458).

6 Tanto a hierarquia quanto a dialética entre genérico e específico operam em todos os elementos. Cita como exemplo a estrutura, a qual existe em um plano genérico e um específico. Uma malha estrutural de pilares é concebida de forma genérica, sem dimensões específicas ou interferências, apenas como pontos ordenados em uma grelha cujos espaçamentos são relações entre si, são uma malha autorreferente. Apenas quando em um projeto adquire dimensões e passa a ser afetada pelos outros elementos, os quais interferem em sua distribuição, dimensão e proporções. A hierarquia opera então para determinar qual elemento tem prevalência para flexionar 
Percebemos, com isso, que a definição de genérico e específico é ponto central na discussão de Eisenman. Podemos explorá-la a partir da ideia de que, ao propor hierarquia do mais abstrato ao mais material, Eisenman faz distinção entre ideal, conceitual, e atual, contingente. Tal como a teoria das ideias de Platão, segundo o qual o que vemos são instâncias imperfeitas da ideia, o arquiteto opera os elementos para que tendam ao genérico, para que se aproximem ao máximo da ordem total.

"O termo forma genérica é aqui entendido como a forma pensada em um sentido platônico, como uma entidade definível com suas leis inerentes. O termo 'forma específica', por outro lado, pode ser pensado como a configuração física real realizada como resposta a uma intenção e função específicas." (EISENMAN, 2006c, p. 33-35, tradução nossa) $\cdot^{7}$

A descrição vista acima da ordem total como um absoluto é condizente com a associação à visão platônica, já que a ordem total remete a ordem dos sólidos platônicos, de uma grelha de espaço homogêneo e indistinguível, ao espaço e sólidos ideais, ao espaço cartesiano.

Ainda com base na Tese, para o arquiteto, há dois tipos de forma genérica: a centroide e a linear. Estes dois tipos de forma possuem características ou propriedades intrínsecas, as quais darão ordem ao sistema formal. A forma centroide possui equivalência entre os eixos, o cubo, a esfera, enquanto na forma linear há a predominância de um eixo, o paralelepípedo, ou "cubo duplo", o cilindro (EISENMAN, 2006c, p. 35).

Para Eisenman, todo processo de projeto consiste na articulação da forma dentro de um sistema resultante da dialética entre considerações específicas, internas (a intenção e a função), e consideraçôes genéricas, externas (o ambiente total). ${ }^{8}$ As flexôes da forma no projeto são um reflexo das distorçôes geradas pela contingência, seu propósito é ordenar o ambiente em condição a mais próxima possível da forma genérica. Todo edifício realizado provém de um antecedente genérico, isto é, uma situação arquitetônica que nunca se concretizará; ele será uma forma ordenada, sistematizada, cujas deformaçóes específicas comunicam o antecedente genérico como uma ideia no sentido platônico. É importante ressaltar que tanto as demandas externas quanto as internas ensejam formas genéricas, mas com diferentes pesos, uma vez que a demanda interna é específica. Neste ponto, a expressão utilizada por Eisenman, "situação arquitetônica", para referir-se a um projeto traz a relação indissociável entre o ambiente em que este se insere e sua demanda arquitetônica, que

é sempre uma interferência específica neste ambiente. A relação do projeto com o meio não é com o outro. Seria uma decisão arbitrária deformar uma questão de função em favor de uma questão de estrutura ou técnica. $O$ adequado é o inverso: a estrutura ser deformada frente a necessidades funcionais.

7 Sobre este aspecto ver também EISENMAN $(1963$, p. 458).

8 Interessante aqui que Eisenman diz que as condições genéricas da forma também regem a ordenação do ambiente natural. Como exemplo, cita a acrópole em Atenas, na qual a referência horizontal dada pelo plano da cobertura do templo central fornece a referência para a leitura das montanhas ao fundo. 
o local, como no regionalismo, mas se dá basicamente pelo correto desenvolvimento da situação formal do ambiente total.

A partir desta estrutura baseada no jogo entre elementos genéricos e específicos, o trabalho do arquiteto consiste em articular o sistema formal, o qual não possui elementos definidos, mas utiliza um vocabulário relacionado a uma situação específica. Apesar de ser indissociável da contingência, cada sistema tem a sua essência genérica, não havendo um tipo que corresponda a uma dada função, ao contrário, diferentes sistemas podem atender a mesma função (EISENMAN, 2006c, p. 91). ${ }^{9} \mathrm{Ou}$ seja, Eisenman nega a ideia de tipo.

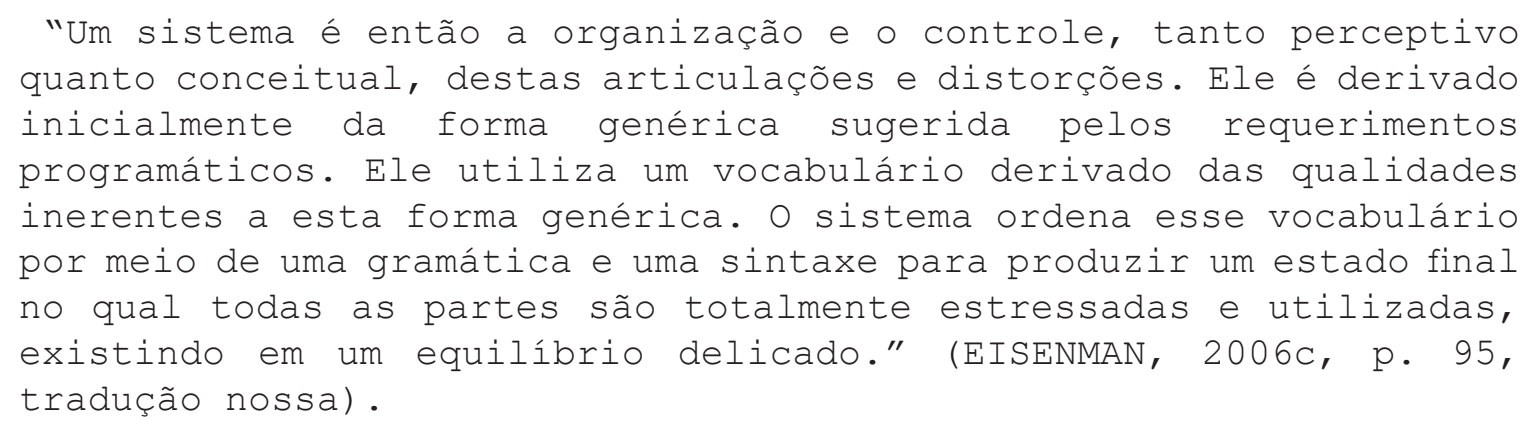

As propriedades perceptivas e conceituais da forma, as bases para o desenvolvimento do vocabulário e da sintaxe, são desenvolvidas a partir das propriedades básicas da forma, isto é, volume, movimento, massa e superfície. Estas propriedades definem características da forma e também respeitam a série, indo das mais gerais, conceituais, às mais específicas, mais próximas a situaçóes concretas, situaçóes da percepção.

Como um todo conceitualmente organizado, cuja proposta é transmitir uma ideia capaz de, diferente da pintura que a condensa em um plano, reger o sistema formal, a apreensão da arquitetura resulta de um conjunto de experiências sensíveis acumuladas no tempo, as quais não se constroem em um todo perceptivo, mas em um todo conceitual. Tal qual em uma frase, que é lida pela apreensão sequencial (e ordenada) de palavras, um edifício é compreendido através da apreensão de formas ordenadas. Os volumes são o elemento primeiro da forma arquitetônica, é o que delimita a experiência tanto interna quanto externa do observador (EISENMAN, 2006c, p. 58). Volumes estão em condições dinâmicas, estão sujeitos às contingências, a forças externas, resultantes das distorções físicas ou abstratas que afetam a condição neutra do espaço, e a forças internas, ou seja, pressóes resultantes das limitações das superfícies, dos movimentos - circulação - e das massas - os objetos. Nesta dialética entre condições internas e condições externas, volumes tanto influem sobre outras formas quanto são influenciados por elas. Volume é, portanto, um espaço ativado. Novamente, a

9 Importante este ponto, pois é uma das formas de Eisenman colocar sua teoria em relação a outras tentativas de racionalizar a arquitetura. 
distinção entre o genérico e o específico se impõe: o espaço é genérico, imutável, estático, absoluto; os volumes são específicos, são aquilo que é ativado, dinâmico. ${ }^{10} \mathrm{O}$ espaço tende ao espaço cartesiano, infinito, indivisível e uniforme, serve como referência absoluta à forma arquitetônica, ao passo que os volumes correspondem às formas platônicas: cubos, esferas, cilindros, cones.

A apreensão no tempo supóe a existência de um observador. A partir dele, há dois tipos de volume: o positivo e o negativo - o positivo é todo ambiente interno, ele envolve o observador e se define pela adição de formas; o negativo é todo espaço externo, caracterizado pelo resíduo entre volumes justapostos. Essa definição é uma característica importante do trabalho de Eisenman, pois opera com o virtual, com a ausência. Uma característica importante que resulta destas definiçóes é que a visão da forma proposta supóe que, na impossibilidade de uma forma genérica existir no espaço construído, todo espaço é ativado por alguma contingência, isto é, todo espaço é formado por volumes, sejam eles positivos, sejam negativos.

Além disso, essa apreensão no tempo implica outro elemento caracterizador dos volumes, o movimento. Este não é uma narrativa de percepção, como uma promenade, mas é a tradução da circulaçáo do observador no ambiente, ou seja, é a forma do comportamento imprimido ao indivíduo pela ordenação formal. O movimento é então uma tradução de vetores em volumes (EISENMAN, 2006c, p. 71-73). Por exemplo, uma porta gera um vetor de movimento sobre a forma que depende de suas dimensões e importância. Este modo de compreender uma ação, neste caso o movimento, como vetor é utilizado para compreender toda interação entre as formas. Tanto as demandas internas quanto as externas tornam-se vetores, linhas de força, série de situaçóes abstratas que flexionam a forma.

Um passo adiante nesta escalada do genérico ao específico, há o modo de conter o espaço, o modo como o volume é controlado, podendo ser através da massa ou da superfície. São características antitéticas, um volume que toma corpo como massa o faz por subtração, como um sólido corroído, escavado, enquanto um volume caracterizado por superfície é composição operada por adição, como um baralho de $\operatorname{cartas}^{11}$. Massa e superfície refletem no volume questóes mais próximas ao específico. A superfície pode ser de dois tipos: como pele, algo que envolve, característico da forma genérica centroide, ou como planos, como folhas sobrepostas, característico da forma linear. O tratamento

10 Eisenman considera indispensável a qualquer compreensão de formas a existência da referência no espaço a pelo menos uma dessas qualidades, mesmo para a compreensão das formas naturais (EISENMAN, 2006c, p. 65).

11 A ideia de uma sequência de volumes como um baralho de cartas é referência importante à Eisenman. A ideia de sobreposição de planos operará tanto na forma como no método de análise e de projeto. A sobreposição de camadas, como composições figura/fundo, e a planificação de planos sobrepostos da transparência fenomênica, são características discutidas por Colin Rowe sobre transparência literal e fenomênica (ROWE; SLUTZKY, 1963). 
das aberturas, a forma como são trabalhadas as quinas e o material usado são exemplos que permitem a leitura do volume como massa ou superfície. Eisenman observa com especial interesse quando ocorre uma dialética massa-superfície, uma ambiguidade entre essas duas formas de caracterizar os volumes, pois isso mostra "[...] uma oposição conceitual inerente entre requisitos internos e externos" (EISENMAN, 2006c, p. 81) resolvida não com a predominância de algum lado, mas com a permanência da tensão, de uma ambiguidade.

A ordenação, a relação entre os elementos no espaço, também ocorre em dois tipos: sistemas volumétricos e sistemas de movimento. Como o volume é a condição fundamental da forma, sempre ocorrerá alguma organização volumétrica, mas não necessariamente esta organização será a base do sistema. Os sistemas volumétricos, por sua vez, podem ser de três tipos: contínuo, estático e um terceiro tipo relacionado à série de planos volumétricos - os dois primeiros tipos podem ser aplicados tanto em situações lineares quanto centroides; exceção é o terceiro tipo, específico a sistemas com dialética massa-superfície. Já em sistemas estáticos, cada volume é expresso ou articulado como uma entidade individual, há um senso de ordem pela progressão, operação de justaposição, os volumes são articulados como uma sequência. Por outro lado, em sistemas contínuos, o movimento é interconectado à ordem volumétrica, cada volume remete a todos os outros e ao todo, é uma relação de interpenetração. A referência absoluta é a malha, os volumes não ocorrem como entidades separadas, mas existem em relação ao organismo total. Os sistemas de massa-superfície tendem a formar um sistema de superfícies que organiza a ordem volumétrica, podendo ser de três tipos: sequência de superfícies volumétricas tensionadas a partir de um plano vertical; sequência de planos volumétricos horizontais articulados a partir de um referente horizontal; e um terceiro tipo cuja ordem deriva de uma grelha de dois planos adjacentes, um plano vertical e um horizontal. ${ }^{12}$ Eisenman associa estes três tipos de sistemas volumétricos à históra da arquitetura, uma vez que, tradicionalmente, a arquitetura trabalhou sobre sistemas estáticos, sendo sistemas contínuos, e o sistema de massasuperfície típicos do movimento moderno; Eisenman identifica este terceiro tipo de sistema como o epítome da arquitera moderna, presente na obra de Le Corbusier, mas principalmente na de Terragni, na qual esse sistema aparece, como poderemos explorar adiante, na forma do diagrama dos nove-quadrados (nine-square).

Há três tipos básicos de organização de movimento, dos quais outros podem derivar: o catavento (pinwheel), o escaláo (echelon) e a espiral (spiral). O cata-vento não se origina do movimento,

12 Eisenman utiliza projetos de Le Corbusier como referência aos três tipos: Garches, Maison Dom-Ino e Shodan, respectivamente (EISENMAN, 2006c, p. 109-111). 
mas de organização volumétrica dividida em partes articuladas a partir de um centro; o movimento do cata-vento vem da ideia de giro dos volumes ou da compreensão deles como pesos. $\mathrm{O}$ escalão pode ser uma combinação de volume e movimento; sua forma típica é a de costelas progredindo de uma coluna. A espiral é um sistema de movimento baseado em uma progressão em relação a um centro; não há um sentido claro, pode ser da periferia ao centro ou o inverso.

Ao elaborar análise sobre diferentes modos como as forças afetam as formas que compóem sistemas, Eisenman dedica considerável parte (EISENMAN, 2006c, p. 121-125) ao caso específico do que ocorre com um cubo, forma centroide, ao ser afetado por uma diagonal. Relevante esta análise, pois, além de ser condição que verá na Casa del Fascio, é a base-forma da House I.

Uma forma centroide seria afetada por uma diagonal tanto por ter um vetor nesta direção quanto por ser composta de dois lados fortes adjacentes, por exemplo, consequência de acessos. Independente da origem da diagonal, o sistema pode ser desenvolvido a partir de duas premissas: neutralizar a diagonal ou acentuá-la. O reconhecimento da diagonal, eixo forte deste sistema, implica a necessidade de equilíbrio em torno do eixo fraco, a diagonal oposta, para contrapor a tensão dos dois lados fortes adjacentes. Em sistema que nega a diagonal, sua existência precisa estar implícita; um sistema de movimento em espiral permite articular a diagonal sem requerer a expressão ou supressão deste eixo - a solução, por exemplo, seria uma entrada única em um cubo com a expressão da pressão em um dos lados compondo o outro lado dominante da diagonal. Outra solução à diagonal, baseada na ordem volumétrica, provém da tensão e relação de série de planos volumétricos, referentes aos dois lados fortes, com um sistema de volumes associado a um lado forte e um sistema de movimento em relação ao outro lado mais fraco. Isto é, o sistema híbrido deve reconhecer as junções entre o sistema de volumes e o de movimento. ${ }^{13}$

O sistema formalé resultado da ordenação e clareza dada pela sintaxe ao vocabulário, da articulação dos diferentes elementos da forma: volume, massa, superfície e movimento. $\mathrm{O}$ antecedente genérico, a ordem do sistema, desdobra-se até as propriedades específicas como cor, textura, tamanho, escala e proporção. Como Eisenman não procura desenvolver um sistema fechado, mas uma teoria aberta, não há forma única de resolver uma situação específica. Portanto, uma forma genérica não ensejará diretamente uma cor, em vez disso, a articulação das condiçôes genéricas e específicas concatenarse-á de forma lógica até culminar em uma cor.

13 Eisenman cita que, nessa situação, escalões e cata-ventos não são adequados. O primeiro enseja continuidade que traz problema ao ser cruzada pela diagonal, o segundo implica quatro lados. Como teoria aberta, não impede seu uso, a função pode exigir, porém resulta em articulação "perversa e maneirista". É interessante a provocação de Eisenman, sua estratégia de oscilação, de instabilidade. Na House II, há sistema de escalão de volumes em relação a uma diagonal. 
Esse percurso minucioso sobre a Tese de Eisenman possibilitou a compreensão de características importantes. Como expressamos acima, lemos a Tese em chave como de Guido Zuliani (2006) para quem, neste texto, já aparecem de forma incipiente elementos importantes para Eisenman. A ideia de teoria aberta atesta a intenção de operar formas de modo menos condicionado possível, intenção que percorre toda a carreira do arquiteto. Sua visão do espaço como volumes, por vezes justapostos, por vezes interpenetrados, volumes positivos ou negativos, é ferramenta fundamental nos desenvolvimentos seguintes do arquiteto. A concepção de uma totalidade, de um absoluto que contém desde o genérico ao específico, é sensivelmente distinta de como pensará já nos projetos do início de sua carreira, mas, em certo sentido, a retornará em sua segunda fase, as Decomposiçóes.

Percebemos que Eisenman opera a partir de uma dupla de conceitos - genérico/específico recusando a predominância de um dos termos. Seu sistema é em relação a um todo único, absoluto, a ordem total, mas cuja estabilidade é impossível. Isto porque o genérico e o específico estão em constante recursividade, cada nível ordenado por essa lógica é internamente cindido em nova relação de genérico e específico. Binômio que se repete com outros nomes como positivo/negativo, estático/ dinâmico, massa/superfície. Essas duplas mostram modos por meio dos quais Eisenman suspende a estabilidade de sentido, a qual o acompanhará ao longo de sua carreira. A relação entre massa e superfície é exemplar neste sentido, pois, além de não se resumir a um dos termos, há uma terceira opção, a suspensão da resolução, a dialética compreendida pelo arquiteto como uma condição de ambiguidade, do sentido que desliza sem fim de uma a outra interpretação. Condição análoga aos sistemas de volume, os quais podem ser estáticos, dinâmicos ou um terceiro tipo que seria a dialética entre os dois primeiros. A ambiguidade e instabilidade de sentido são elementos importantes em leituras do arquiteto, principalmente a partir de sua fase das Decomposiçóes, como nas leituras de Jencks (1989), Kipinis (1998, 2007 e 2014), Somol (1999 e 2014) e Sarah Whiting (2006b) anteriormente citadas.

Identificamos também sua relação com a história. $\mathrm{O}$ arquiteto não se coloca fora da história, mas procura a realização do projeto moderno a partir de correçáo de desvios, reativando a crítica da história e da técnica em nome da recuperação de processos formais de abstração, tal como praticados por Le Corbusier e Terragni. Compreende assim a história como uma progressão dos modos de operar a forma, como os sistemas de volumes que progridem ao longo do desenvolvimento da disciplina. Essa visão da história será retomada ao longo de sua fase de Transformaçôes, em textos como Dall'Oggetto alla Relazionalità: la Casa del Fascio di Terragni (EISENMAN, 1970a); enquanto em sua fase das Decomposições, em textos como Post-Functionalism (EISENMAN, 2006b) e The 
End of the Classical: The End of the Beginning, the End of the End (EISENMAN, 1984), a ideia de uma história como fratura se imporá.

\subsection{Sistemas formais: o projeto moderno reexaminado}

Observar as leituras que Eisenman faz de arquitetos modernos permite compreender a implementação dos sistemas que ele propõe em situaçôes de projeto, explorando como gramática e vocabulário respondem a uma dada ordem, além de identificar movimentos os quais reproduzirá em projetos seus. Não reproduziremos as análises em sua totalidade, mas alguns de seus movimentos significativos. $\mathrm{Na}$ verdade, as leituras de cada projeto por Eisenman não são exaustivas, até porque a sua proposta não é validar a teoria de nenhum deles. Sua análise visa o sistema formal e se pretende independente de discussões de outra natureza ou do que os próprios arquitetos analisados haviam exposto sobre os seus próprios projetos. O que se propóe é mostrar o funcionamento de diferentes sistemas: em Le Corbusier e Terragni, a dialética massa-superfície ${ }^{14}$; em Alvar Aalto, o sistema de superfícies; em Wright, o sistema de massas. Nesse sentido, Eisenman seleciona duas obras de cada arquiteto, em contextos parecidos, que apresentem demandas programáticas semelhantes e que sejam dotadas de uma forma genérica análoga, como com eixos externos paralelos ou perpendiculares. O propósito é mostrar como demandas programáticas semelhantes geram sistemas diferentes, ao serem submetidas a diferentes gramáticas. Eisenman justifica suas escolhas apenas por estas questôes formais.

Apesar de Eisenman não fornecer mais detalhes, apenas Terragni não é um dos grandes nomes do Modernismo, mas também não é um nome desconhecido, já que é um dos principais expoentes do racionalismo italiano. Le Corbusier, por sua vez, é um nome consagrado do Modernismo: sua associação às vanguardas, a alinhar-se com o cubismo, é conhecida desde 1941, com a publicação de Space, Time and Architecture, de Sigfried Giedion (GIEDION, 2004); além disso, em sua Tese, Eisenman destaca que as quatro composiçôes de Le Corbusier foram as bases para desenvolver seu sistema (EISENMAN, 2006c, p. 107-111). Wright e Aalto são nomes importantes da arquitetura

14 Terragni é uma figura importante em todo o percurso de Eisenman. Em seu texto Interview with Peter Eisenman: The Last Grand Tourist: Travels with Colin Rowe, Eisenman (2008b) expõe o modo como teve contato com Terragni - durante viagem com Rowe, viu obras de Terragni e fez coleção de revista de arquitetura moderna. Eisenman se encanta com Terragni ao ponto de se tornar um tópico recorrente. Em 1970, publica Dall'Oggetto alla Relazionalità (EISENMAN, 1970a), no qual relê a Casa del Fascio; em 1971, From Object to Relationship II (EISENMAN, 1971), no qual lê a Casa Giuliano Frigerio e retoma pontos da Casa del Fascio; em 1986, publica Giuseppe Terragni: Transformations, Decompositions, Critiques, livro que analisa, junto a outro projeto, profundamente a Casa del Fascio; com última edição em 2003, este livro é resultado de aproximadamente 40 anos de Eisenman analisando projetos de Terragni. 
orgânica para Bruno Zevi, em sua publicação Saber Ver a Arquitetura, de 1948 (ZEVI, 2009). Como Eisenman formou-se arquiteto em Cornell na década de 1950, essas referências, estes arquitetos e textos, fizeram parte de seus estudos. A exceção que Terragni representa é explicada pelo próprio Eisenman - em seu texto Interview with Peter Eisenman: The Last Grand Tourist: Travels with Colin Rowe (EISENMAN, 2008b), ele explica como teve contato com as obras de Terragni - durante as viagens que fez com Colin Rowe enquanto esteve em Cambridge -, o que se deu tanto através de revistas de arquitetura adquiridas quanto pelo contato direto com a Casa del Fascio, em Como, visita que Eisenman descreve como uma revelação para si.

De Le Corbusier, Eisenman analisa o Pavilhão Suiço e a Cité de Refuge (EISENMAN, 2006c, p. 139-183). Os dois projetos apresentam elaboração de sistema dual, expressando individualmente a ordem do movimento, a qual corresponde à organização dos movimentos no espaço, e a ordem dos volumes. Em ambos, a ordem volumétrica linear seria proveniente de sua organização interna, enquanto o movimento teria origem na problemática de estabelecer uma entrada única para uma organização linear ${ }^{15}$. Nestes projetos de Le Corbusier, os sistemas de movimento e volumes possuíriam a mesma importância, todavia, em função de suas diferentes origens, apresentam um conflito entre demandas internas e externas, que, resolvidas em síntese, não apresentam tensão na forma final dos edifícios.

O Pavilhão Suiço é projeto desenvolvido por Le Corbusier em 1930. Localizado na Cité Internationale Universitaire, de Paris, sua função é servir de alojamento para estudantes suíços. O projeto é composto de uma marquise de acesso, um volume térreo com as atividades públicas e um volume linear com as unidades habitacionais.

Condizente com o que propóe, Eisenman inicia sua leitura a partir da identificação de estados genéricos que sofrerão distorçôes. No projeto do Pavilhão Suiço, as distorçôes são consequência da entrada única em um bloco retilíneo. O sistema volumétrico controla as distorçôes do estado genérico, fornecendo a referência perceptiva. Por sua vez, o sistema de movimento ordena o eixo externo e o vetor de entrada, gerando a referência conceitual, que será uma espiral ou cata-vento parciais. O choque entre esses dois sistemas na superfície da entrada fornece a superfície de referência, uma superfície não flexionada, e forma as subsequentes distorçôes do volume inferior.

A força da distorção do acesso, da espiral que o movimento está criando, é lida nas deformaçóes da base. Ao rebater o eixo externo para acomodá-lo ao bloco retilíneo, Le Corbusier gera a espiral

15 A forma linear tem equivalência de dois lados. A forma ideal do antecedente genérico seriam pelo menos duas entradas opostas. 


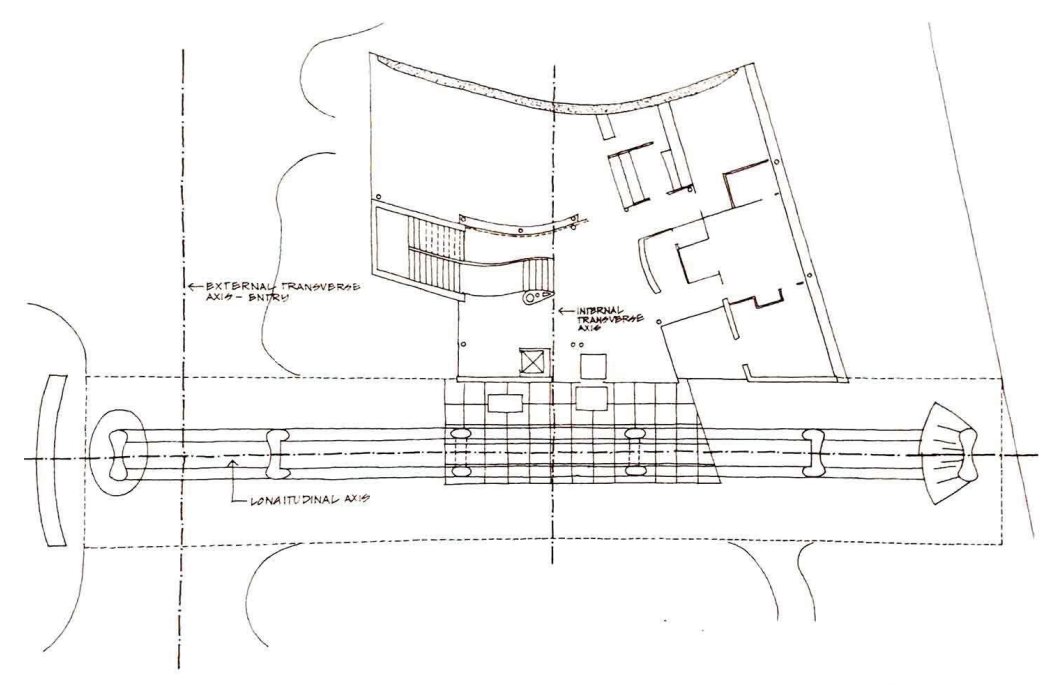

Figura 21 - Situação do Pavilhão Suíço.

Fonte: EISENMAN (2006c, p. 148).
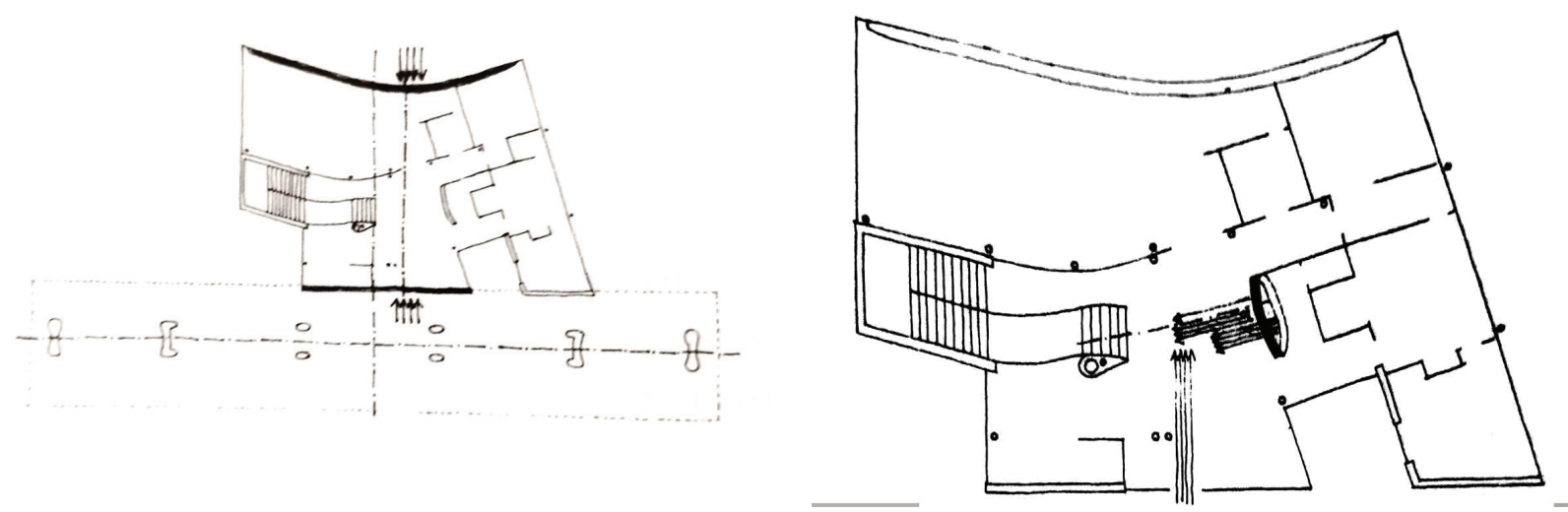

Figura 22 - Deformações da parede do fundo e balcão de recepção. Fonte: EISENMAN (2006c, p. 148).
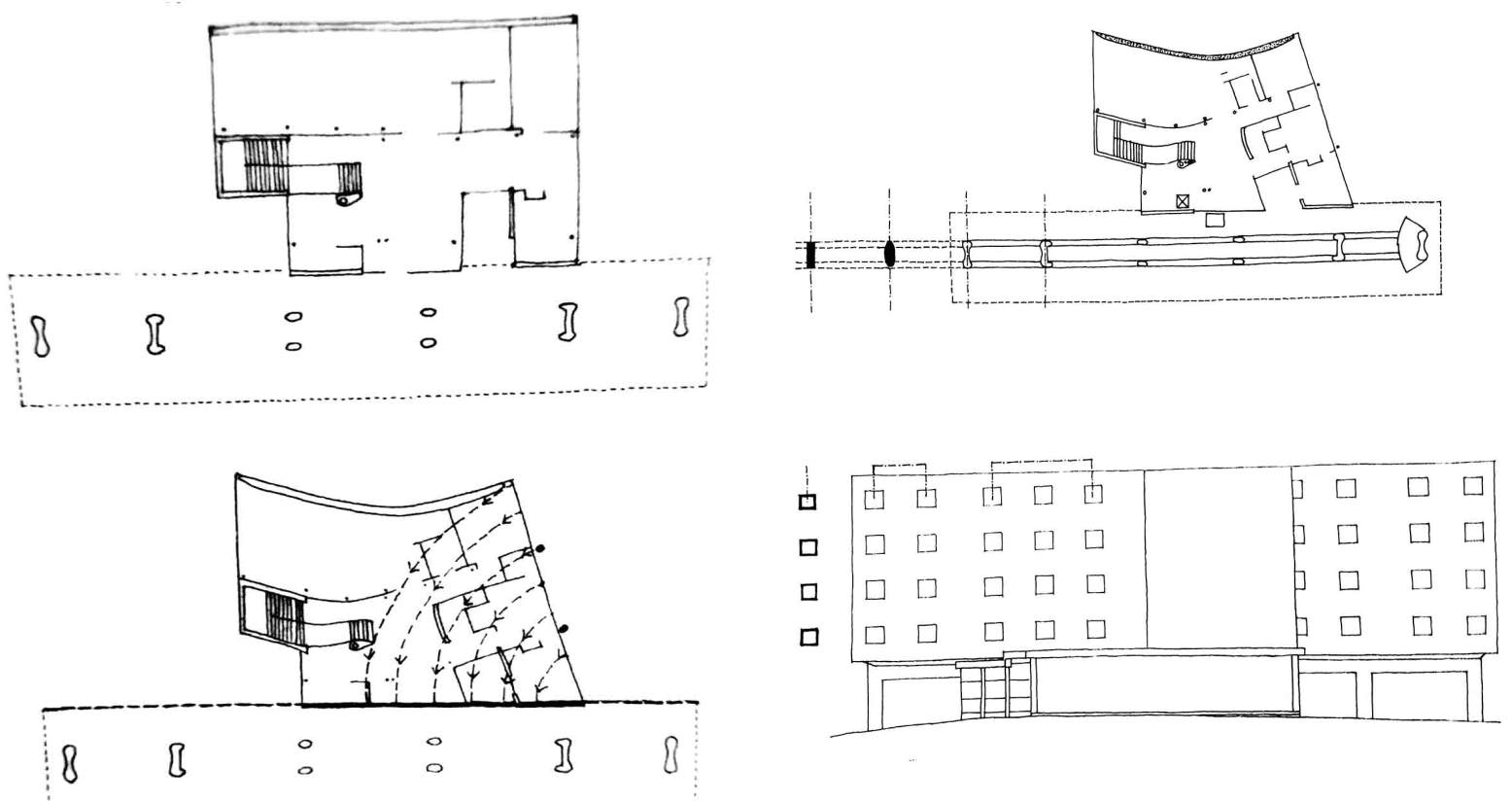

Figura 23 - Deformações comparadas ao volume não deformado. Fonte: EISENMAN $(2006 \mathrm{c}, \mathrm{p} .159)$.

Figura 24 - Sequências de fechamento. Fonte: EISENMAN (2006c, p. 166). 
que tensiona as formas da base em direção à escada. As curvas da parede do fundo, da parede do refeitório e do balcão de recepção são reflexos da espiral do vetor de entrada.

Dois pontos são particularmente importantes nesta análise: a dialética massa-superfície e a condição de fechamento do projeto. Segundo Eisenman, os volumes articulados no térreo operam como massa esticada a partir do plano de referência em dialética com esta superfície que é a fachada anterior. Para compreender essa dialética, o arquiteto salienta o diferente tratamento que Le Corbusier realiza nas fachadas norte e $\operatorname{sul}^{16}$. A fachada norte, traseira, pode ser lida como massa pela relação entre os cheios e os vazios das pequenas janelas. A ambiguidade está na parede rústica do refeitório, que possui uma leitura absoluta de massa; esta parede é lida como um volume empurrado pelo vetor de acesso e que perdeu sua pele nesse movimento, expondo sua rusticidade. Todavia, a massa do refeitório é emoldurada por dois planos horizontais e pelos caixilhos da lateral, permitindo também a leitura de superfície, um papel que poderia ser removido para expor outra superfície. Deste modo, há uma progressão desta parede rústica, a da face norte, com relação à da face sul, superfície predominantemente de aberturas; progressão do mais sólido ao cada vez mais diáfano. A dialética entre superfícies e massas identificada por Eisenman forneceria essa constante de ambiguidades.

A ideia de uma totalidade é importante para Eisenman neste momento. Ele insiste na identificaçáo do fechamento do conjunto como uma entidade, neste caso, encerrando o eixo longitudinal do volume principal. Esse fechamento se dá por sequência: sob a marquise de acesso, há um conjunto de colunas, as quais formam uma sequência que enseja uma progressão - dois pilares ao centro progridem ganhando massa até se tornar uma forma final cheia. O fim da sequência ocorre dois passos além das instâncias edificadas; é uma maneira de fechar a forma a partir de uma sequência estimada. Método repetido nas janelas da fachada norte, as quais também apresentam uma progressão com uma etapa a ser inferida: de um conjunto de três janelas, passa a duas, além de haver a projeção de um próximo passo, com uma só janela.

O segundo projeto analisado de Le Corbusier, a Cité de Refuge, também está em Paris. Projetado em 1929, o edifício foi desenvolvido para o Exército da Salvação também com o propósito de servir para habitação. Semelhante ao projeto do Pavilhão Suiço, a Cité de Refuge é desenvolvida a partir de uma demanda interna funcional que sugere uma organização genérica linear. Diferem, contudo, na medida em que o eixo externo, antes em ângulo reto em relação ao eixo linear do edifício, aqui está a 45 graus. Le Corbusier desenvolve o conjunto de pavilhóes de acesso da Cité de Refuge de modo

16 Diferença de tratamento que Eisenman qualifica como neoclássica por promover a distinção frentefundo (EISENMAN, 2006c, p. 161). 


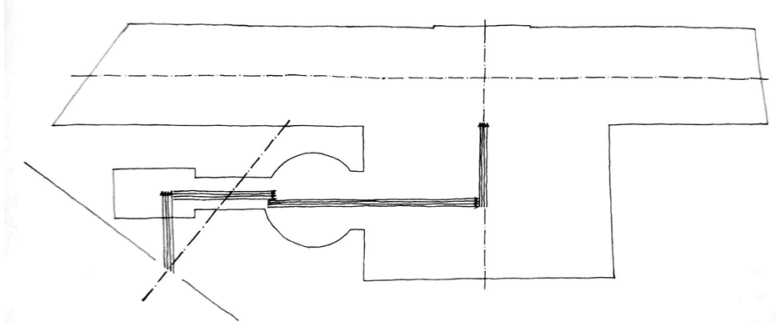

Figura 25 - Articulação do eixo interno e eixo externo e sistema de movimento. Fonte: EISENMAN (2006c, p. 172).

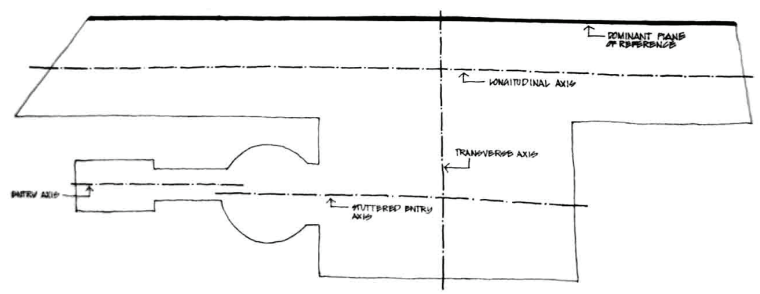

Figura 26 - Plano de referência. Fonte: EISENMAN (2006c, p. 168).
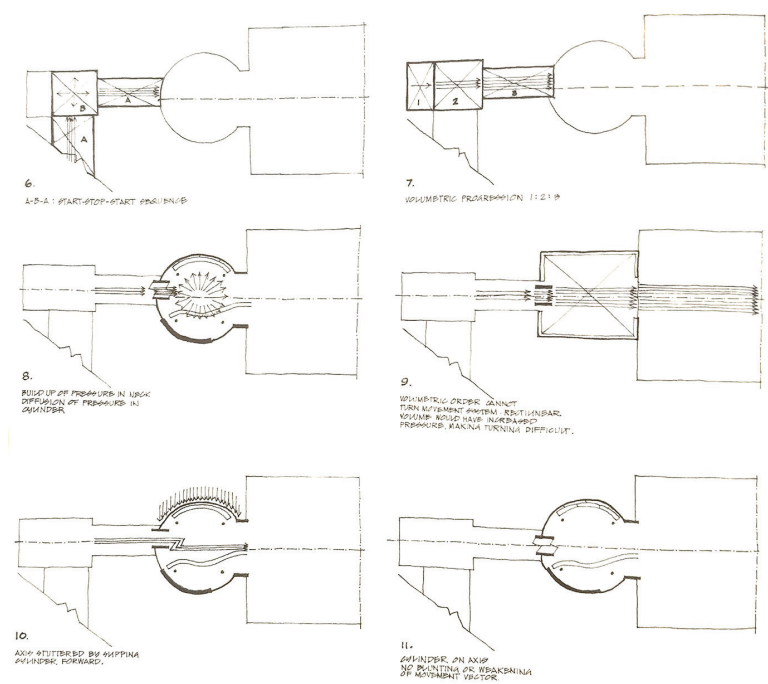

Figura 27 - Sistema de movimento no acesso. Fonte: EISENMAN $(2006 \mathrm{c}$, p. 174).

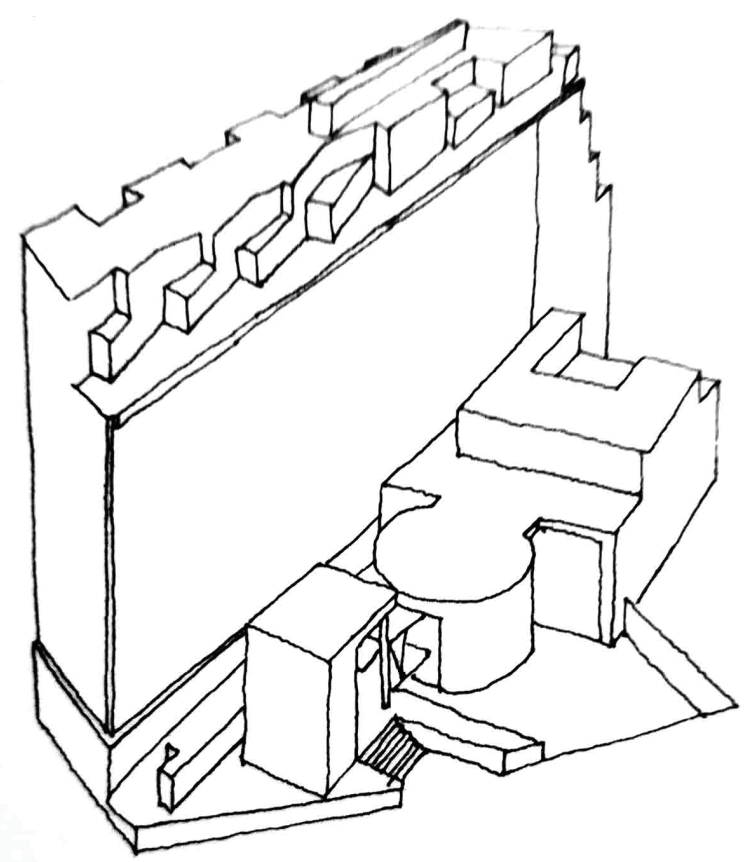

Figura 28 - Dialética massa-superfície. Fonte: EISENMAN (2006c, p. 178).
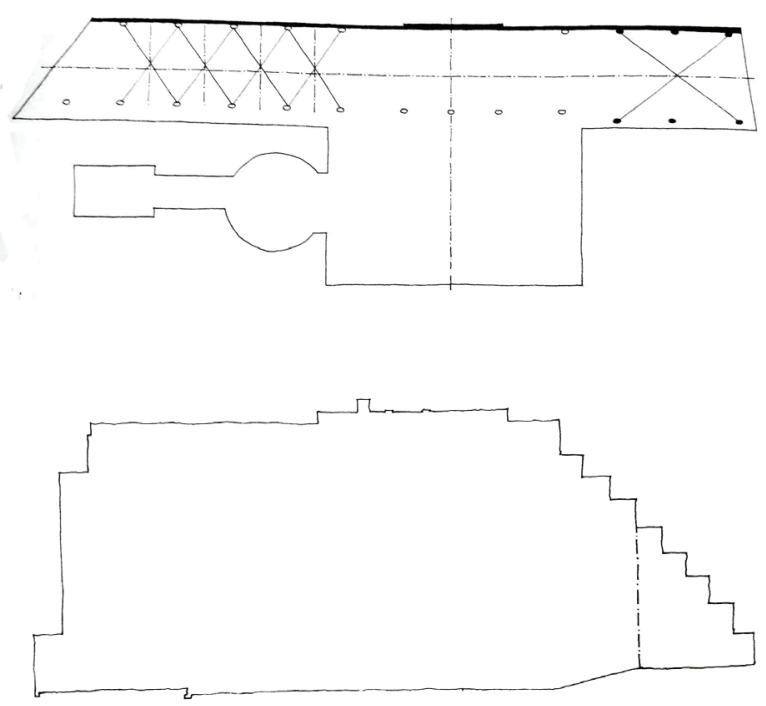

Figura 29 - Fechamento da forma em planta e elevação. Fonte: EISENMAN (2006c, p. 180-182). 
a defletir o eixo de entrada formando uma espiral, primeiro dobrando o eixo paralelo ao volume e, por fim, amortecendo-o e invertendo o sentido da espiral. Independentemente da deflexáo do movimento, o eixo de acesso punciona o edifício, definindo o plano de fundo do volume principal como plano de referência.

Os pavilhões formam um conjunto que, por meio de alargamentos e afunilamentos, formas lineares e centroides, inibe ou direciona o movimento de modo a dobrar e amortecer o eixo externo conformando-o à forma linear do edifício. A primeira dobra é feita por um retângulo dividido em um quadrado e um retângulo menor - o quadrado, forma centroide, amortece o vetor, enquanto o outro retângulo fornece resistência e direciona o movimento em sentido oposto. A porção inicial deste movimento forma tanto sequência de amortecimento (avançar-parar-avançar: A-B-A), como sequência de progressão (1-2-3), o que reforça o sentido e a força do vetor de entrada. A forma cilíndrica é utilizada como alívio do vetor por sua forma uniforme em todas as direçóes. O ponto de chegada é o quadrado junto ao volume principal, forma centroide que opera como ponto de parada.

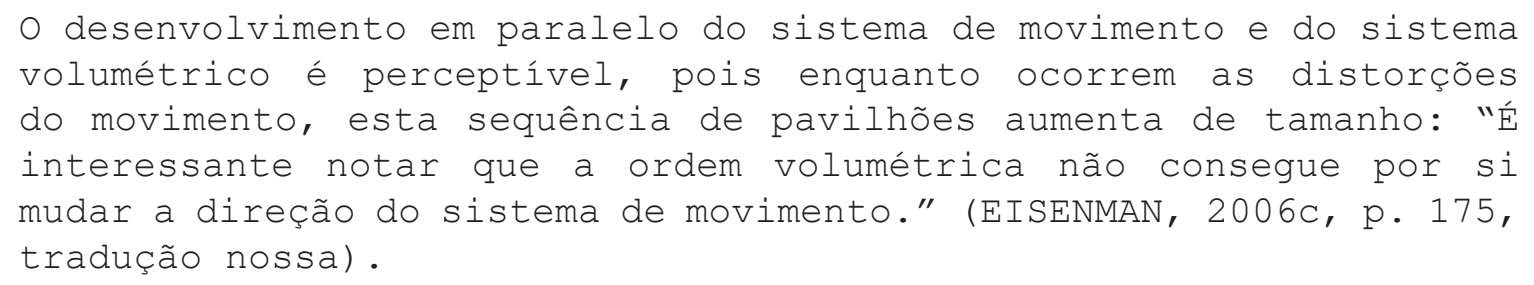

O sistema de volumes é finalizado ao contrapor estes volumes do acesso, na dialética massasuperfície, ao edifício principal. Neste caso, a fachada forma plano único, sem molduras ou elementos que o recortam, definindo-se como uma superfície sobre massa. A parte superior é recuada e cortada em ângulo, fazendo o topo ser lido como uma massa enclausurada entre as superfícies da fachada e a do fundo de referência. Os volumes dos pavilhóes são como massas puxadas do interior destes planos.

O fechamento do volume do edifício principal não ocorre de um dos lados, onde era prevista uma expansão. ${ }^{17}$ A não distorção das colunas da lateral oposta sugere o encerramento do eixo, mas o fechamento definitivo ocorre na seção vertical. Além disso, há um escalonamento superior que, se projetado, formaria uma espécie de zigurate, operação análoga ao fechamento por inferência de sequência no Pavilhão Suiço.

As duas residências que Eisenman analisa de Frank Lloyd Wright, a Martin House e a Coonley House (EISENMAN, 2006c, p. 185-231), são lineares por disposição interna, mas uma paralela e

17 Apesar de não pontuar, aqui o eixo genérico fica sem fechamento por conta da expectativa de uma forma futura específica. A crítica que Eisenman faz neste momento à utopia de uma forma ser projetada com um futuro específico em vista não atende à demanda genérica, resultando em volume sem fechamento devidamente articulado. 


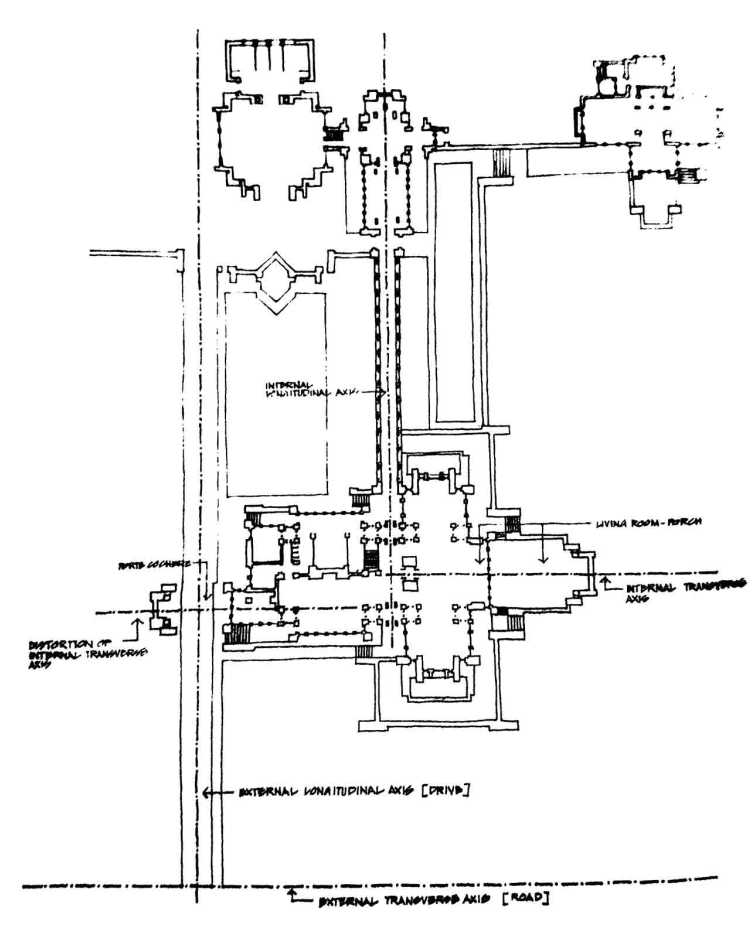

Figura 30 - Situação da Martin House. Fonte: EISENMAN (2006c, p. 188).

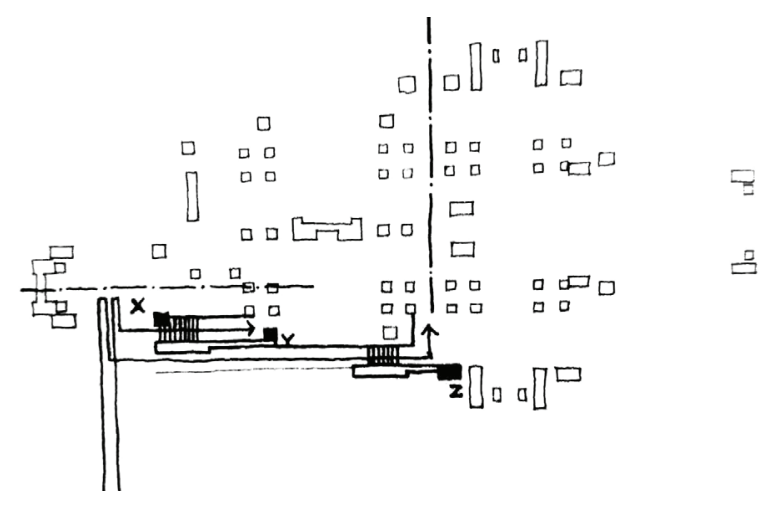

Figura 31 - Deslocamento do eixo da pérgola e escalão de acesso. Fonte: EISENMAN (2006c, p. 190).

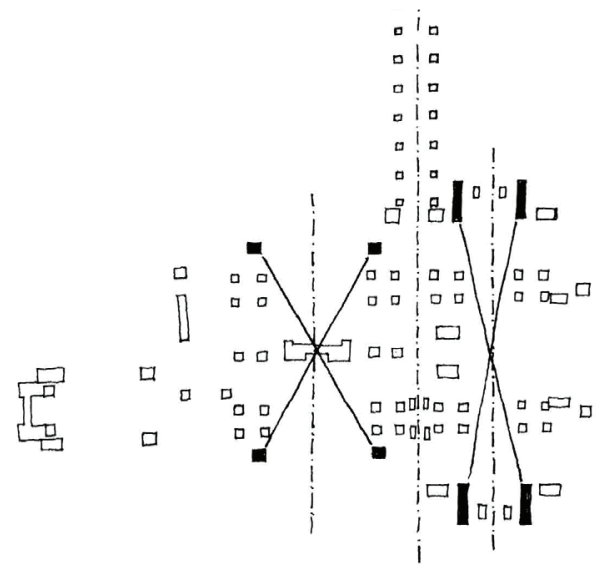

Figura 32 - Equilíbrio de eixos menores como "gangorra". Fonte: EISENMAN $(2006 \mathrm{c}, \mathrm{p} .194)$.

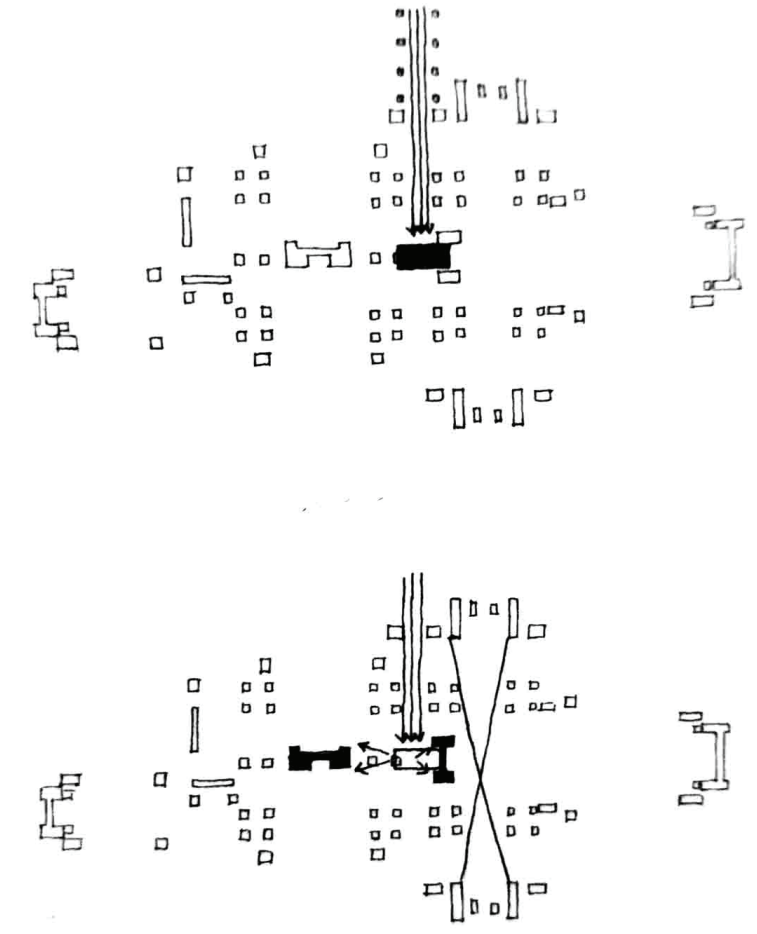

Figura 33 - Quebra da lareira e volume da sala de estar. Fonte: EISENMAN (2006c, p. 203).

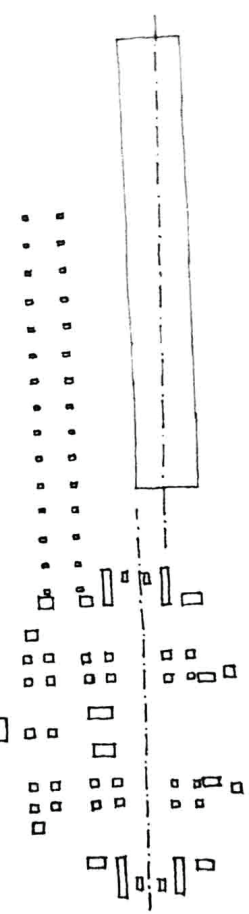

Figura 34 - Quebra entre eixos internos e externos. Fonte: EISENMAN (2006c, p. 203). 
outra perpendicular ao eixo externo. Em Le Corbusier, os eixos ordenam e controlam o movimento, em Wright, por sua vez, controlam o volume. ${ }^{18}$ Segundo Eisenman, o sistema empregado por Wright é baseado em um jogo elaborado de volumes em relação aos eixos principais articulados com eixos menores. Wright não se utiliza da dialética massa-superfície; os seus volumes são como sólidos cortados, formando massas.

A Martin House, projeto de 1905, é uma das prairie houses de Wright. O projeto, localizado em Buffalo, nos Estados Unidos, é composto de diferentes volumes: a casa principal, um volume com estábulo e uma estufa, uma casa secundária para a irmã do proprietário e um pequeno alojamento para jardineiro. Os dois primeiros volumes citados são conectados por uma pérgola, porém, em sua análise, Eisenman considera apenas o edifício principal e sua relação com a pérgola.

Em sua leitura, a Martin House é desenvolvida a partir de uma forma genérica linear, composta por sistema de pavilhôes lineares dispostos em paralelo ao eixo externo. O edifício é resultado da síntese de dois sistemas volumétricos: o estático e o dinâmico, os quais - controlados por uma grelha com dois eixos principais ortogonais entre si - formam uma dialética: dependendo do ponto do observador, um ou outro dos eixos é visto como dominante, bem como articulam a forma a partir de eixos auxiliares encerrados ao atingir um eixo principal, não permitindo que descaracterizem os eixos principais.

O acesso é feito pela sobreposição do volume do edifício principal por meio de um pórtico sobre o eixo do acesso de veículos. O eixo do pórtico é um deslocamento do eixo principal longitudinal da sala de estar pelo eixo genérico da pérgola onde se cruzam. O eixo da pérgola é o que conecta os dois volumes edificados. O eixo genérico da pérgola não é deslocado, e sua punção forma um escalão com as entradas de pedestre e acesso de veículos. O equilíbrio em torno do eixo da pérgola é feito com auxílio de eixos menores: o da cozinha e recepção e o da sala de jantar e biblioteca. Como uma gangorra, este segundo é mais alongado, mais forte, pois tem um braço menor em relação ao eixo central; este eixo é encerrado e reforçado pelo tratamento similar no par de pilares em seus extremos. O outro eixo, da cozinha e recepção, é indicado pelo recesso na lareira, que, situada em seu centro, enfraquece sua leitura centroide.

Em torno destes eixos, há uma dialética de volumes estáticos e dinâmicos, cujas leituras oscilam entre volumes ora justapostos, ora sobrepostos. O sistema estático vem inicialmente dos conjuntos

18 Possível influência do contato com Colin Rowe, Eisenman encontra referências não convencionais nestes projetos modernos. Tal como identifica em Le Corbusier uma referência neoclássica por seu tratamento das fachadas frontal e anterior, ele identifica em Wright uma forte influência clássica pelo jogo de eixos principais e eixos menores cruzados que ordenam a planta. 


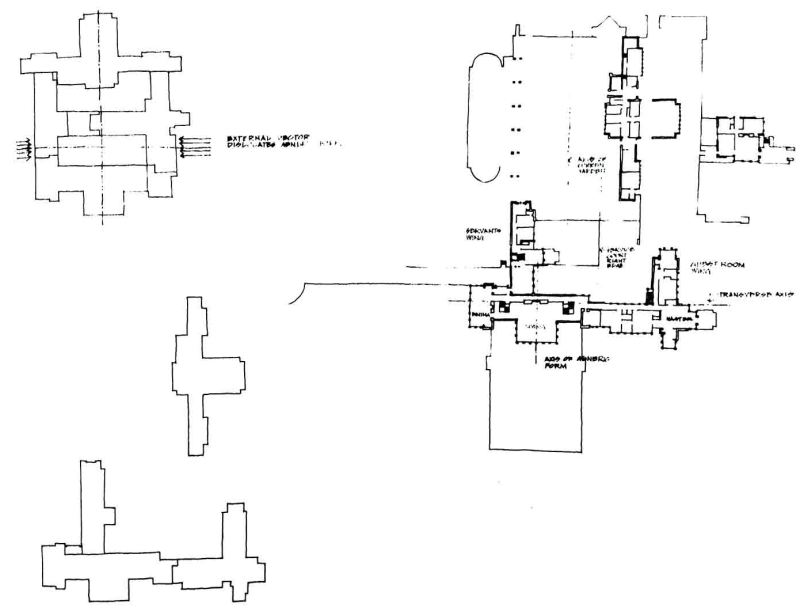

Figura 35 - Situação da Coonley House. Fonte: EISENMAN (2006c, p. 207).

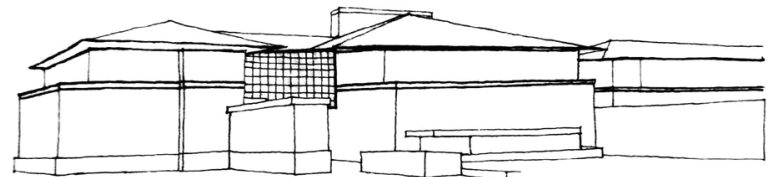

Figura 36 - Referência horizontal.

Fonte: EISENMAN (2006c, p. 211).
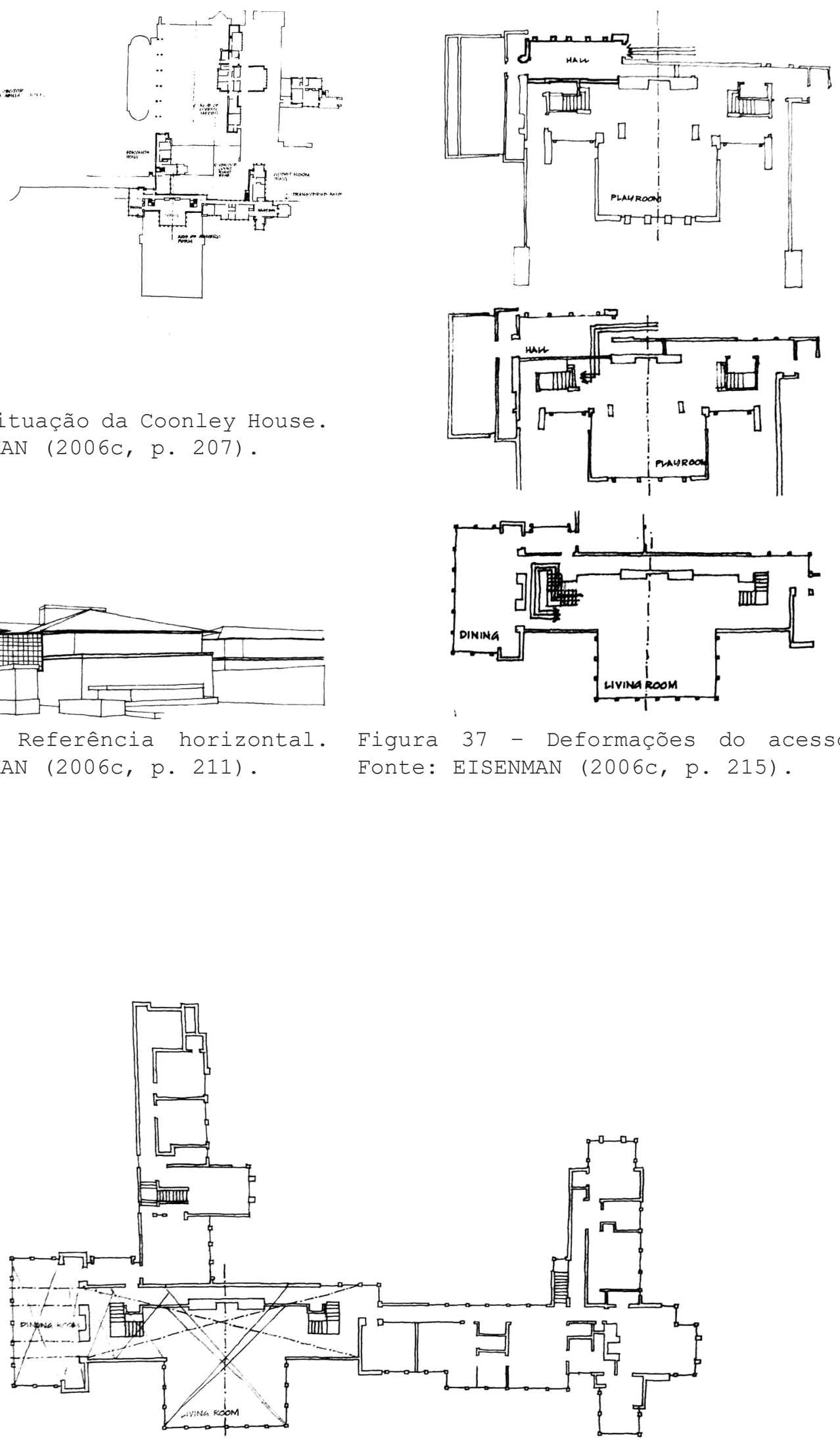

Figura 38 - Sistema dinâmico de volumes. Fonte: EISENMAN (2006c, p. 219). 

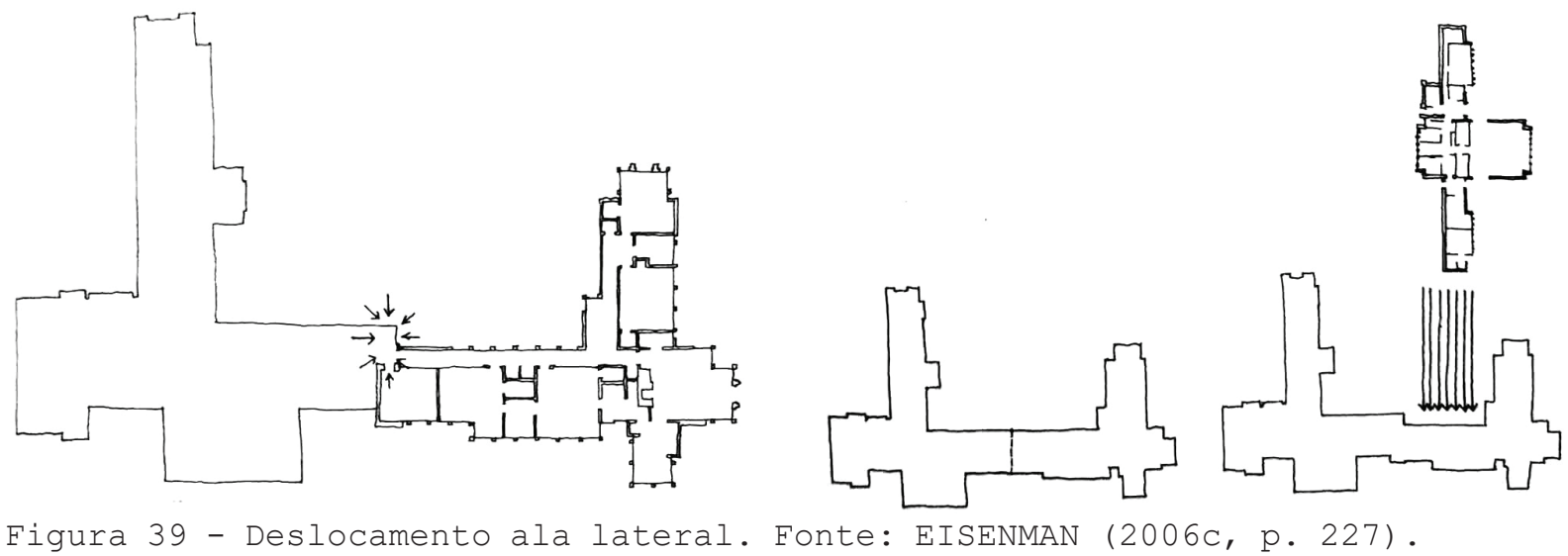

de quatro pilares - lidos como uma série de pavilhôes - simétricos em relação ao eixo transversal; em relação ao eixo longitudinal, eles marcam um centro fraturado no cruzamento deste com o eixo transversal, que, à diferença das outras casas de Wright, desloca a lareira do centro. Estes pavilhóes definem também os volumes da sala de estar e da cozinha/recepção. Neste caso, em relação ao eixo transversal, o procedimento gera um conjunto estático de volumes que pulsam, expandindo e contraindo a forma.

Os eixos menores em gangorra vão de encontro a essa pulsação fora de ritmo do centro dos pavilhôes gerando sistema dinâmico de volumes. Estes eixos formam tanto três quadriláteros, como na leitura anterior, como dois quadrados, o da lareira e um adjacente; além disso, formam, por meio do telhado único, conjuntos de volumes sequenciais reforçados pela articulação entre as extremidades de ambos os lados. Essa leitura dos quadrados é dúbia, uma vez que oscila a partir do ponto de vista, pode tanto ser o eixo de continuaçáo da pérgola, como o da sala de estar. A ambiguidade no encerramento da sala de estar aparece no deslocamento da lareira da sala de jantar, que é deslocada pelo eixo da pérgola e girada 90 graus. A partir desta leitura de que a forma genérica tem esta lareira no meio do eixo transversal, o eixo da pérgola a fragmenta, e a lareira da recepção é, assim, a outra parte deslocada.

Interessante a relação que Eisenman encontra entre o externo e o interno. Os eixos menores continuariam para a área externa, porém deslocados. A condição formal interior ganha predominância graças a estas interrupçóes dos eixos. Dessa maneira, manter a continuidade reforçaria estes eixos secundários, mas entrariam em conflito, confundindo a importância dos eixos principais, longitudinal e ortogonal. ${ }^{19}$

19 Aqui Eisenman mostra exemplo de sua crítica ao peso simbólico na arquitetura moderna. Ao contrário da continuidade imputada ao trabalho de Wright se concretizar, ele nega a continuidade conceitual entre o interno e o externo, para Eisenman, a continuidade torna-se apenas uma ideia, um símbolo; o plano aberto aparece como uma ideia representada, não como uma intenção formal. A crítica de Eisenman a não continuidade de Wright não é por conta da ausência de continuidade em si, mas por esta tornar-se apenas simbólica. Condizente ao colocado 
A Avery Coonley House, de 1908, em Illinois, nos Estados Unidos, também é um exemplo de prairie house do arquiteto Frank Lloyd Wright. Este projeto e o anterior são dois dos poucos exemplares de projetos de residência do arquiteto, neste período, compostos de diferentes edifícios. A Avery Coonley House é, para Eisenman, um sistema de pavilhóes lineares desenvolvido a partir da distorção de um sistema genérico cruciforme. A casa é composta de uma série de pavilhôes arranjados horizontal e verticalmente em referência a um horizontal absoluto. Este projeto apresenta com clareza a gramática específica de Wright; o controle sistêmico na articulação dos volumes, enquanto o movimentos não é articulado: os movimentos terminam de forma abrupta e torcida. Os pavilhóes são lidos como uma massa perfurada pelo plano do telhado projetado para além deles, definindo, junto ao friso do primeiro pavimento, o absoluto horizontal.

A forma linear específica do edifício se desenvolve a partir das flexôes de uma forma genérica centroide, posicionada ortogonalmente em relação ao eixo da rua. $\mathrm{O}$ acesso é empurrado pela transição ortogonal do vetor externo. A posição da entrada na condição genérica é no eixo longitudinal, identificada pela forte simetria deste eixo. $\mathrm{O}$ vetor de entrada é interrompido por um semiescaláo que continua edifício adentro sem dobrar o movimento.

As escadas formam volumes que conectam outros volumes na horizontal e na vertical, constituindo um sistema volumétrico estático. Esses volumes, por sua vez, formam conjunto de caixas inseridas umas nas outras. Cada caixa é definida por um plano vertical e um par de colunas, como se as colunas tivessem sido puxadas do plano, como pesos. A escada elevada poucos pés acima do térreo permite a leitura das galerias junto à sala de estar como um só volume. As galerias da escada oeste entram na sala de jantar, prendendo-a. Do mesmo modo, a sala de jantar é lida como uma superfície puxada dos blocos, em sua extremidade, para além do limite da forma genérica. Neste caso, os volumes formam sistema contínuo compondo a dupla leitura desses espaços, seja como sistema volumétrico estático, seja como sistema dinâmico.

A confirmação da forma genérica centroide vem de marcas deste antecedente na forma específica. A simetria do complexo da sala de estar fornece uma leitura que subsidia a compreensão das demais distorçôes. A escada leste, em termos funcionais, é fraca, pois a conexão que permite, do acesso aos quartos, é secundária: por outro lado, sua função formal, como manutenção da simetria em relação ao eixo da sala de estar, como marca da forma genérica, é mais forte. A correspondência entre os diferentes volumes reitera a forma genérica. A suíte principal e a suíte de hóspedes estão em

anteriormente, um projeto deve manter clareza do conceito e das referências absolutas. Desta forma, Wright não poderia correr o risco de apagar os dois eixos principais, suas referências absolutas e principais operadores do sistema formal. 
situação equivalente à da sala de jantar e à da ala de serviços. A lareira da suíte principal empurra um volume equivalente ao da sala de jantar. Os quartos transversais podem ser lidos como equivalentes à sala de estar, leitura corroborada pelo fato de terem a mesma largura. Os volumes dos quartos e a sala de jantar formam, assim, dois conjuntos equivalentes em torno da sala de estar.

Esta leitura é reforçada pela junção vacilante da ala dos quartos. O pavilhão puxado longitudinalmente da suíte principal e o tratamento do final do último quarto de hospedes não têm referência clara de eixo, gerando uma leitura ambígua, que impede a fixação desta ala, como se ela pudesse girar e voltar a qualquer momento à sua posição original. O que mantém a ala deslocada é a pressão dada pelo bloco de garagens e o estábulo deslocado e rotacionado de sua posição de fechamento da forma genérica centroide.

Comparando-se as duas leituras que Eisenman faz de Wright, percebe-se o modo como a leitura se adapta caso a caso. $\mathrm{Na}$ casa anterior, há outros elementos edificados do outro lado do eixo da pérgola que o arquiteto não considerou relevantes para a compreensão da articulação do sistema formal; neste segundo exemplo, ao contrário, o bloco de garagens e o estábulo são fundamentais para a compreensão da forma genérica do bloco principal.

De Aalto, Eisenman analisa o Säynätsalo Civic Center e o Tallinn Museum (EISENMAN, 2006c, p. 233-287). Importante em suas análises é a discussão sobre o sistema de pátio em forma centroide. A análise considera três formas: quando o pátio é resultado de demandas funcionais, internas; quando ele é resultado de desenvolvimento tanto de demandas funcionais quanto formais, como a necessidade de resolver conflito entre demandas internas e externas: terminar um eixo externo pela ordem interna ou o problema de resolver uma entrada única em uma forma centroide, por exemplo; a terceira situação é quando o pátio é oriundo de questóes puramente formais, e sua resolução envolve distorção do absoluto horizontal, referência dominante do pátio. O projeto do Tallinn Museum é desta última categoria.

O projeto do Säynätsalo Civic Center foi desenvolvido por Aalto em 1949 para a cidade de mesmo nome na Finlândia. Projeto resultado de concurso de arquitetura, seu uso contempla as diversas atividades necessárias a um centro cívico de uma pequena cidade: escritórios, câmara municipal, locais de comércio, biblioteca e apartamentos para funcionários.

Eisenman compreende em sua análise o projeto do Säynätsalo Civic Center como resultado da resolução de uma condição externa linear com requerimento interno centroide. A solução com um pátio resulta tanto de demandas funcionais quanto formais. Considerando apenas as demandas funcionais, a torre poderia ser o elemento central, por exemplo. O sentido formal do pátio advém 


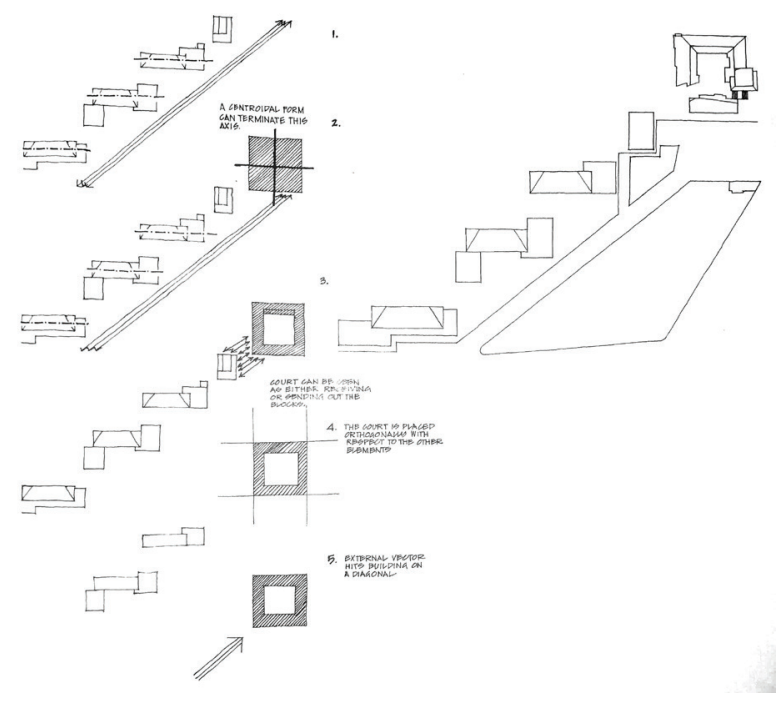

Figura 40 - Situação e diagonal externa. Fonte: EISENMAN (2006c, p. 239).
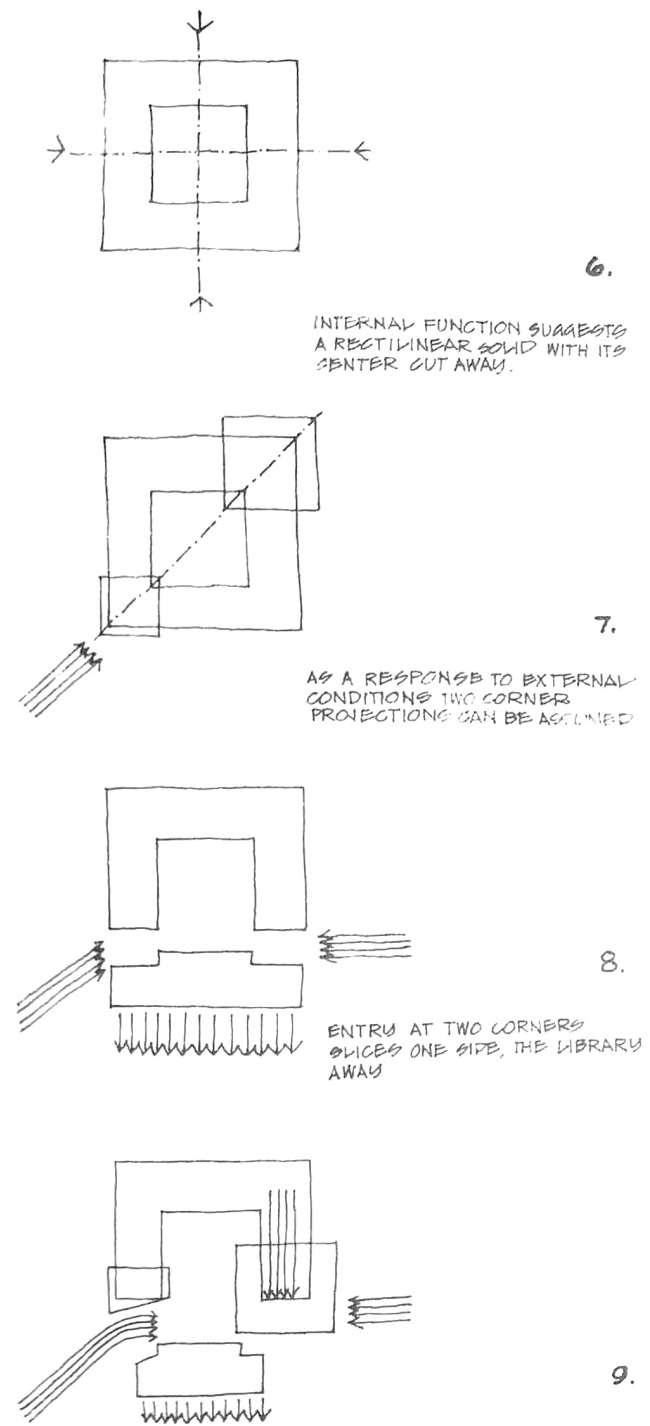

THE MANOR CORNER TOWER IS DRAWN TO ITS PREGENT LOCATION AND THE EXTERNA. VECTOR ISTWISTED ASIT ENTERS THE COURT.

Figura 41 - Principais deslocamentos da forma centroide. Fonte: EISENMAN (2006c, p. 243).

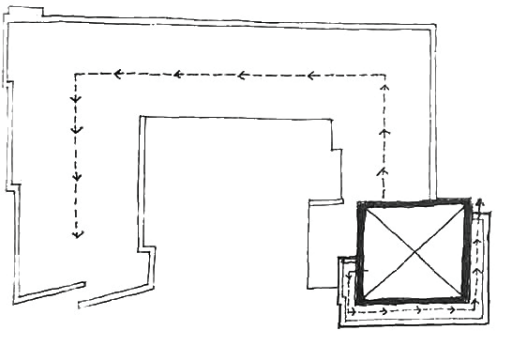

15.

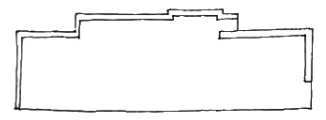

MAIN TOWER WFIXED POINT FOR BEGINNING OF
GPIRAL. INNER ENEMENT PING WHIL OUTER

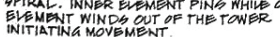

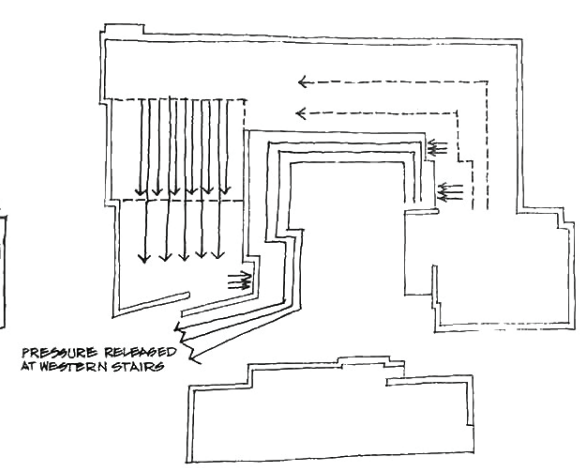

17.
SPIRAL MOVES IN CENTRIPETAL FAGHION
GREATINGA PREESURE ON THE NEGATINE

VOWME OF THE COURT. BLOCKS ON WESTERN

Figura 42 - Torre como ponto fixo e espiral. Fonte: EISENMAN (2006c, p. 253257). 


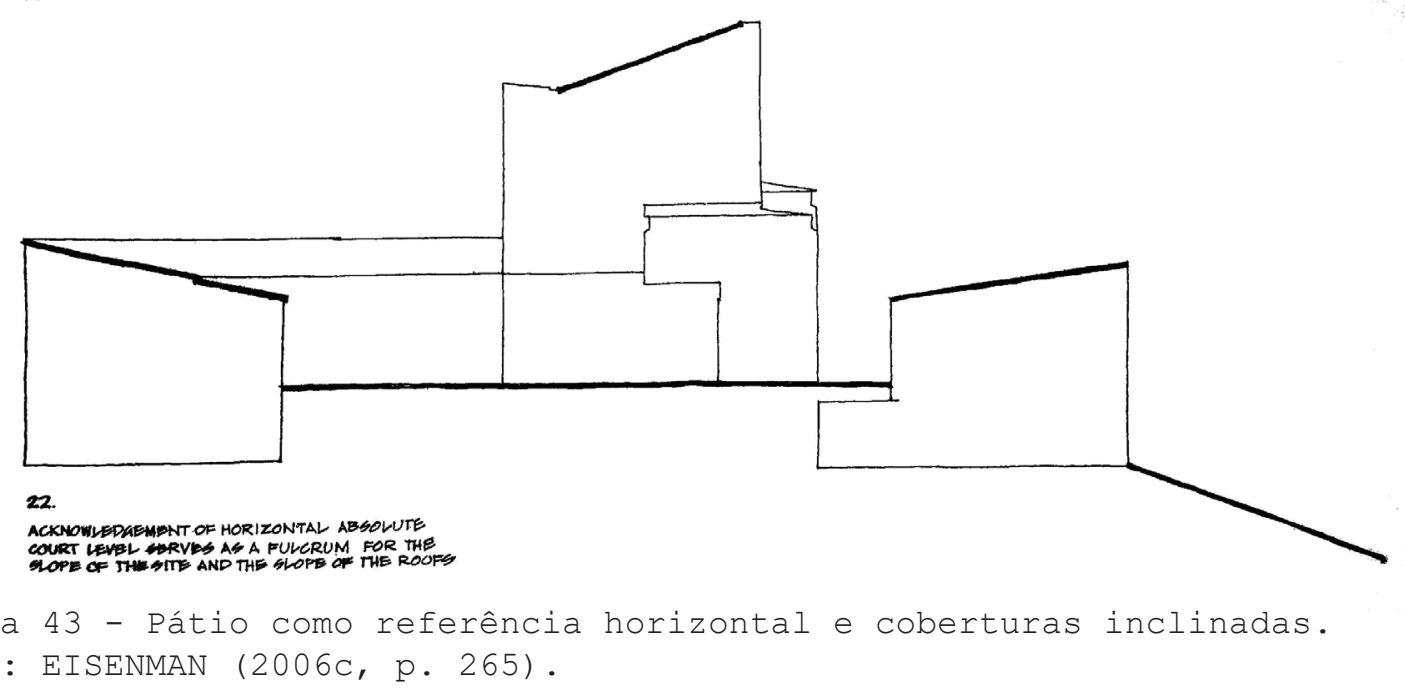

de um eixo externo, linear, resultante do conjunto de edifícios residenciais cascateados no sítio inclinado. A forma centroide do centro cívico marcaria o final deste eixo. No projeto, o pátio é disposto ortogonalmente em relação aos outros edifícios. Isto marca a grelha e faz com que o eixo externo atinja o pátio em diagonal. Para acomodar este vetor, Aalto teria desenvolvido uma ordem volumétrica em espiral sem que o edifício parecesse girar em resposta ao movimento.

As duas primeiras marcas realizadas no estado genérico são o vazio central e a marcação de duas quinas, uma menor e outra maior, de modo a acolher e terminar o eixo diagonal. $\mathrm{O}$ acesso poderia ser locado em um dos eixos centrais, mas isso resultaria em maiores flexôes do acesso. Diante disso a solução adotada por Aalto posiciona-o próximo à lateral o que recorta um dos lados do pátio, reforçando a diagonal, empurra a biblioteca de sua posição na forma genérica e puxa a torre principal da sua posição na quina para junto do acesso.

Além deste sistema volumétrico, há um sistema secundário de movimento em espiral. Diferentemente do uso do movimento espiral por Le Corbusier no Pavilhão Suíço, no qual o movimento não altera a relação entre o sistema volumétrico e o plano de referência, em Aalto, a espiral ganha qualidade pitoresca: a organização volumétrica se refere a um plano vertical que varia conforme o observador progride nela - a espiral começa a partir da torre principal, ponto fixo; a fachada Leste, com recortes verticais que vão diminuindo em direção ao Norte, acusa afastamento do volume em direção ao Oeste, primeiro movimento da espiral; ela se desenvolve em sentido antihorário e de modo centrípeto, qualidade perceptível pelas extrusóes que puncionam o pátio; a dobra no lado Oeste é feita por um escalão que gera uma leitura de volumes puxados; o fim da espiral é marcado pela pressão sobre o pátio e pelo recorte na parede final, dando vazão à pressão acumulada. 

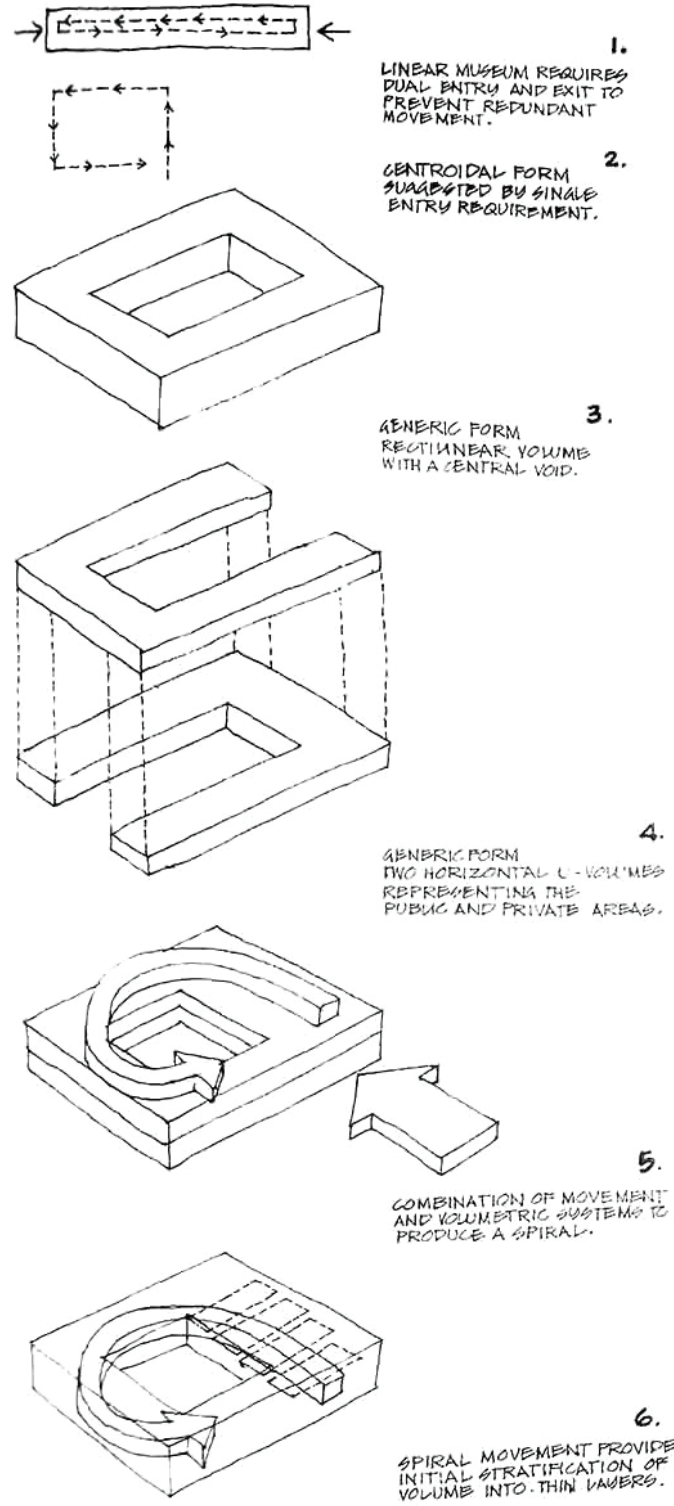

COMEINATION OF MSVEMENU

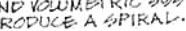

MOVEMENT PROVIPE INITIAL MTRATIFICATION OP

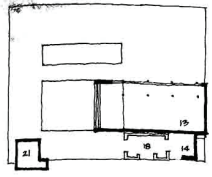

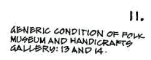

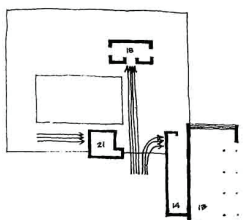

12.

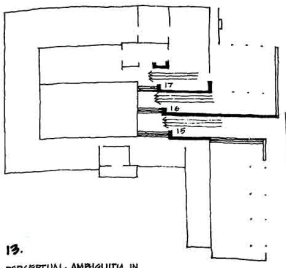

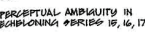

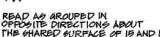

Figura 45 - Giro provocado pelo acesso e ambiguidade do eixo do escalão. Fonte: EISENMAN (2006c, p. 277-281).
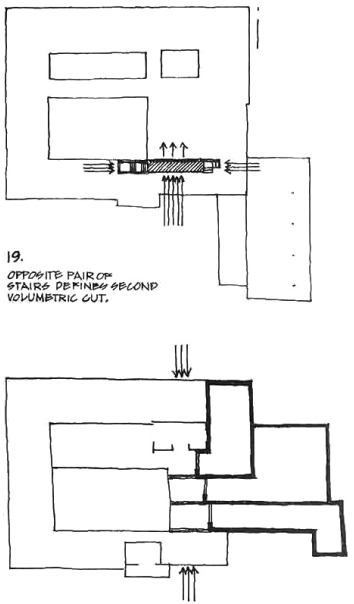

21.
THE GENERIC U-FORM BINDS
THE SPECLPLE EXTRUSIONS.
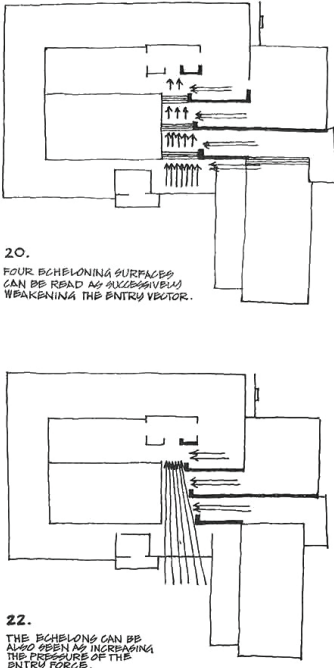

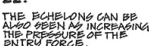

Figura 44 - Sobreposição dos dois sistemas no Tallinn Museum. Fonte: EISENMAN (2006c, p. 271).
Figura 46 - Amortecimento e direcionamento do eixo de acesso. Fonte: EISENMAN (2006c, p. 284).

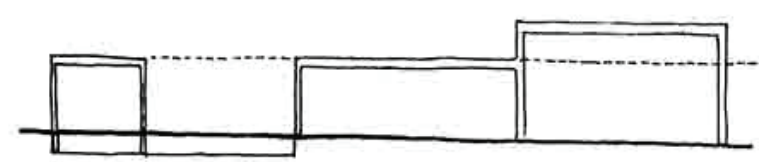

24.

POGITIVE-NEAATIVE EQUIUBRIUM ABOUT HORIZONTAL ABSOWTE

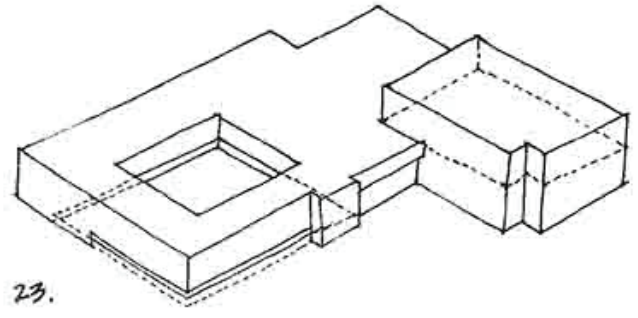

AROIIND FLOOR LEVEY 14 HORIZONTAL ABSOLUTE

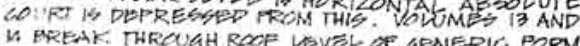

Figura 47 - Equilíbrio em torno do plano de referência horizontal. Fonte: EISENMAN (2006c, p. 286). 
Além de ser o centro da espiral, o pátio opera como referência horizontal absoluta ao articular o sítio, a partir do centro, em declive e as coberturas em aclive.

O Tallinn Museum foi um projeto para museu na Estônia desenvolvido por Aalto em 1937. Eisenman analisa este projeto como resultado da dialética sistema de volumes-sistema de movimento formada pela alternância entre qual sistema é lido como dominante. As distorçốes da forma genérica advêm do movimento, enquanto a ordem volumétrica surge das flexôes da forma para o controle deste movimento. A forma genérica, resolução de uma entrada única em forma centroide, é consequência da função, mas o pátio é estritamente formal, sua razão principal está em servir como centro de espiral. O volume é oriundo de dois "U”, um para as áreas públicas e outro para as privadas, sobrepostos de tal modo que encapsulam o vazio central. Sobre estes volumes, está a espiral de movimento em torno do vazio central, o qual visa a amortecer o vetor externo linear na organização interna centroide.

O vetor de entrada empurra a sala de joias à sua posição no fundo e traz a biblioteca como fim da espiral junto ao acesso. $\mathrm{O}$ eixo de acesso é sequencialmente abatido, pois a entrada da chapelaria e o museu folclórico formam um primeiro plano que corta esse eixo; em seguida, as escadas opostas do vestíbulo e do museu formam outro plano que amortece este eixo. Por fim, ao deslocar a sala de joias ao fundo, o vetor de entrada é submetido a escaláo que o enfraquece ao provocar sucessivos cortes.

Aalto, no Tallinn Museum, forma um absoluto horizontal de modo semelhante a como resolve esta demanda sintática no projeto de Säynätsalo. As deformaçóes verticais são equilibradas em relação a um horizontal. Diferente de Säynätsalo, a referência no Tallin Museum não é o plano do pátio, mas o do piso de acesso do térreo. Os volumes do museu rotacionados pelo eixo de entrada excedem o nível da cobertura da forma genérica, sendo compensados e equilibrados pela redução da cota do pátio em relação ao acesso. Esse equilíbrio positivo/negativo em torno da referência horizontal tanto evita a leitura do volume mais alto, essa massa deslocada, como conjunto linear, quanto permite acesso a escritórios abaixo do volume do museu. "Portanto, a resolução de um requerimento sintático formal também serve para uma demanda funcional." (EISENMAN, 2006c, p. 287, grifo do autor, tradução nossa).

Os dois projetos que Eisenman analisa de Terragni são formas centroides com pátios, a Casa del Fascio e o Asilo Infantile (EISENMAN, 2006c, p. 289-335). A Casa del Fascio é forma centroide como fim de um eixo externo, já no Asilo Infantile a forma é paralela a um eixo externo. Na primeira situação, pelo conflito entre os requisitos internos e externos, o vetor externo tem papel predominante na forma específica, o que é revelado nas distorções que opera no antecedente genérico; neste caso, 


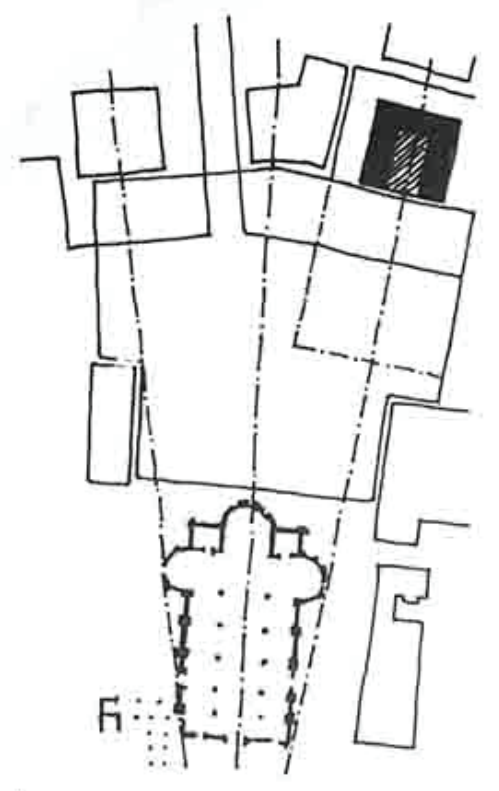

I.

PROPOSEDSITE PLAN SHOWING

EXTERNAL VECTORS.

Figura 48 - Situação Casa del Fascio, eixo da praça. Fonte: EISENMAN (2006c, p. 292).
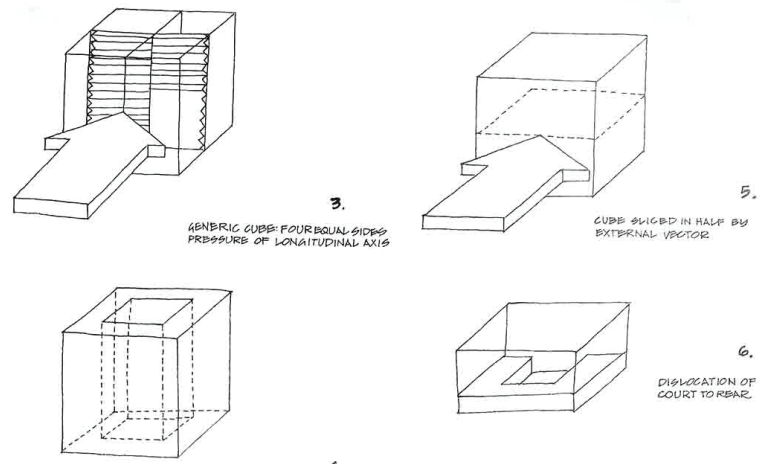

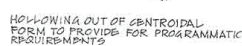

Figura 49 - Distorções do cubo. Fonte: EISENMAN (2006c, p. 294).
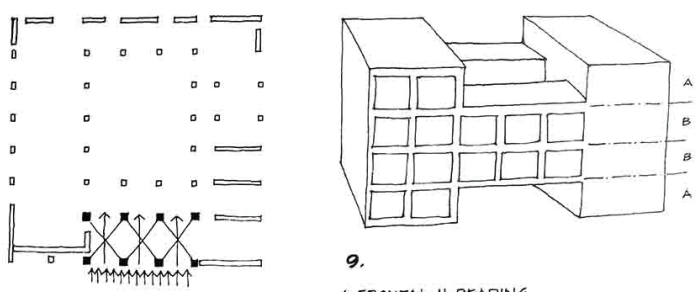

9.

A FRONTAL H-READING
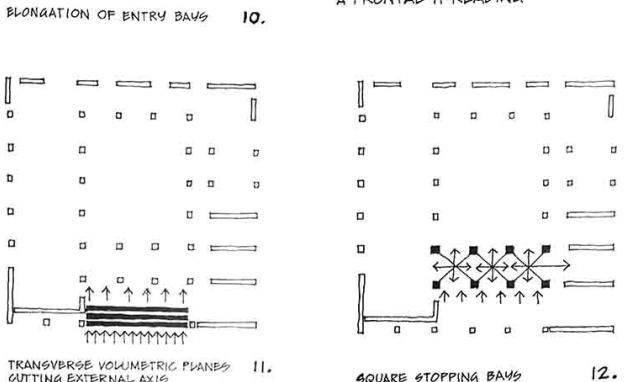

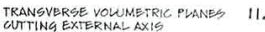

SQUARE STOPPING BAYS $\quad 12$

Figura 50 - Fachada em "H" e planos de entrada e baias quadradas. Fonte: EISENMAN (2006c, p. 296-298).

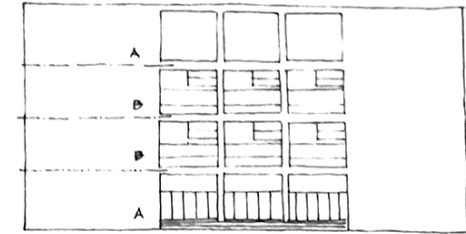

VERTICAL A.B. B.A GERIES

18.

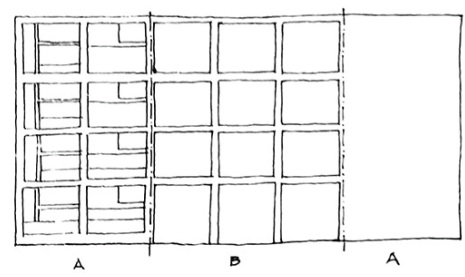

A.B.A QEFIES ACROSG THE FACADE

19.

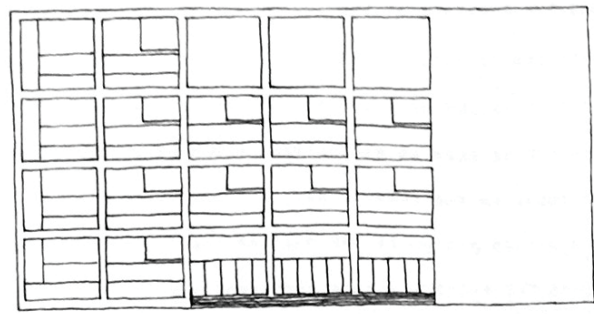

17.

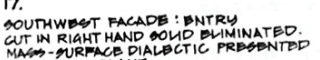

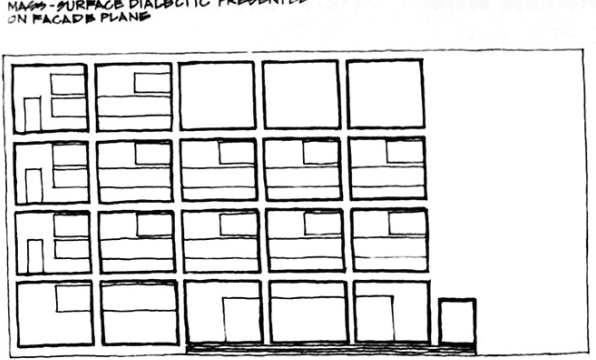

16.

NO MASGGURFACE MBILUITY : MASSSTATED

SURFACE

Figura 51 - Comparação da fachada antiga e final a partir das divisões. Fonte: EISENMAN (2006c, p. 302). 
há pátio resultado de necessidades formais e funcionais. No segundo caso, por não haver conflito interno/externo, o pátio é resultado de demandas funcionais apenas.

Eisenman considera Terragni o exemplo mais elaborado em termos de desenvolvimento sistêmico e de reconhecimento dos requisitos sintáticos dentre os quatro arquitetos que analisa. A Casa del Fascio merece especial interesse visto ser a principal referência de Eisenman neste momento. Neste projeto, ocorre a dialética massa-superfície que explorará a partir da House I ao ser lida tanto como sólido corroído como sequência de planos. Diferente de Le Corbusier, que elabora a dialética aplicando massas ou superfícies a uma grelha de referência, Terragni funde os dois sistemas para obter a ambiguidade desejada.

O projeto para a Casa del Fascio é resultado de uma demanda do governo fascista italiano atendida pelo arquiteto Terragni. Como um edifício destinado a atender as atividades deste governo, seu programa de necessidades contempla desde escritórios, sala de reunião, até o pátio para a acomodação de grupos militares em marcha e um relicário para homenagear figuras deste regime. Terragni desenvolve este projeto em 1932, no centro histórico da cidade de Como, na Itália. Eisenman lê este projeto como desenvolvido a partir da tensão entre requisitos externos lineares, o eixo da praça, e requisitos internos centroides, pátio ladeado por escritório. Pátio é desenvolvido por questóes funcionais e formais; a demanda por espaço de marcha fornece sua razão funcional. $\mathrm{O}$ uso não necessita mais do que um pavimento de altura, mas, como funciona como volume de controle do sistema formal, adquire maior altura, a questão formal do pátio. Ele também é resultado da forma genérica do cubo, o qual sofre duas distorçóes principais: o eixo externo corta o cubo ao meio - adquirindo características lineares nas coordenadas frontal e ortogonal enquanto mantém característica centroide no plano horizontal - e desloca o pátio para o fundo.

"Um sistema é desenvolvido com base nos requerimentos sintáticos, os
quais investem cada elemento com uma leitura dual: uma ambiguidade
proposital do externo comomassa, representando os aspectos centroides
da forma genérica, e como superfície, representando a deformação
linear desta forma. Este sistema e as distorçoses resultantes são
derivados da suposição de que o antecedente genérico é um cubo
volumétrico." (EISENMAN, 2006c, p. 293, tradução nossa)

É necessário que a entrada deste projeto atenda à função dual: tanto prover a transição para uma forma centroide, a partir de acesso único, quanto amortecer o eixo externo. Solução advém da leitura externa na qual a forma genérica original, um cubo, pode ser lida tanto como massa quanto como série de planos ortogonais ao eixo externo. Com isso, a fachada frontal e a anterior são lidas como superfícies; e as laterais, como sequência de planos. 


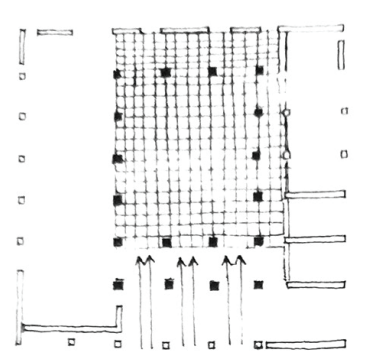

22.

DEFINITION OF COURT IN ITS
DISLOLATED POSITION

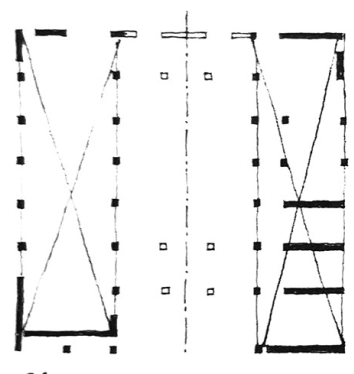

24.

BALANCE ABOUT LONGITUDINAL AXIS

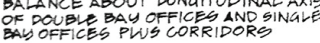

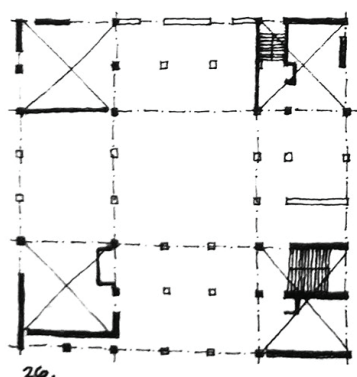

INTERNAL PLAIDING ACKNOWLEDAES

Figura 52 - Divisões tripartidas planta. Fonte: EISENMAN (2006c, 304).

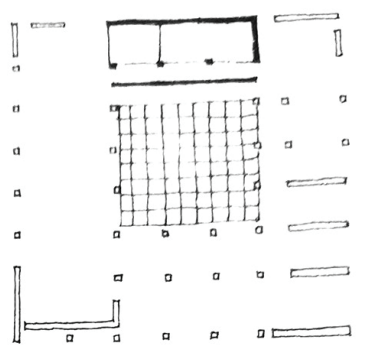

23.

RESTORATION OF COURT TO CENTRAL
POSITION BY FIRST FLOOR OFFICES.

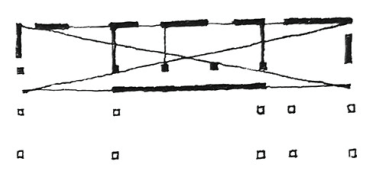

………

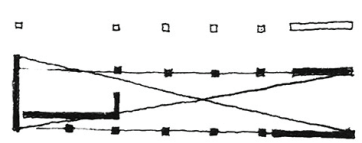

25.

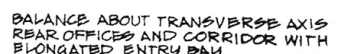

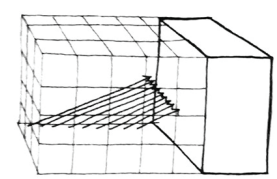
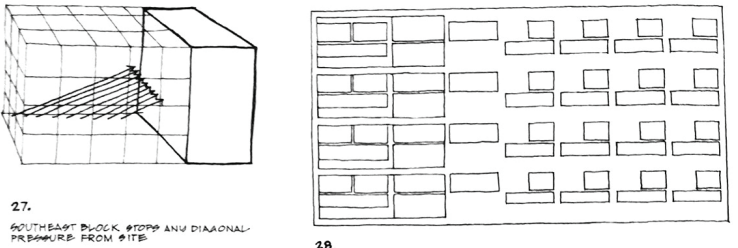

28.

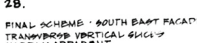
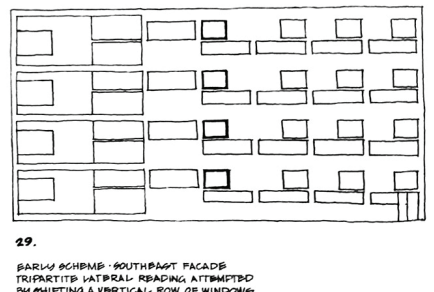

Figura 53 - Massa resistindo ao eixo diagonal e fachadas laterais. Fonte: EISENMAN (2006c, p. 306-308).

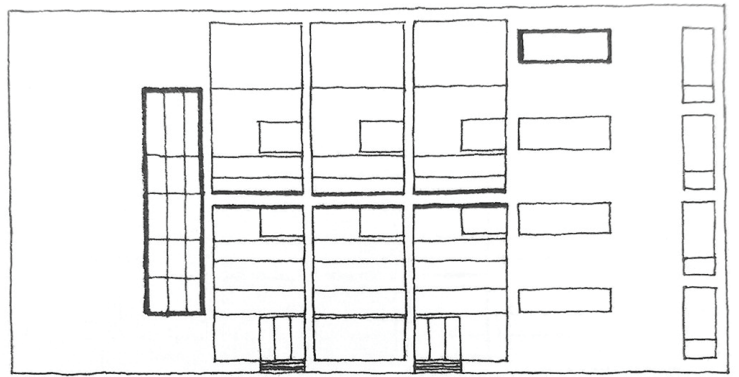

32.

FINAL SCHEME. NORTHEAST FACADE THING OF RIAHT HAND WINOWW HORIZONTALY BY ADPITION OF WINDOW
LARAE VERTICAL STAIR WINDOW READAS BREAKING THROUGH SURFACE,

em Figura 54 - Fachada anterior. Fonte: p. EISENMAN (2006c, p. 310).

Para amortecer o eixo externo e acomodá-lo ao cubo, ocorre uma série de planos transversais: o plano estrutural, o plano do recesso da parede à esquerda da entrada e o plano desta com as portas de acesso. Estes planos ganham amplitude ao afastar-se da fachada, plano de referência, culminando em baias quadradas que reduzem a pressão do eixo externo, permitindo que o movimento vá ao pátio ou às escadas laterais. Este alívio operado no acesso é reforçado pelo conjunto de portas ao longo da extensão da fachada, as quais distribuem o movimento pelas três baias.

Eisenman compara um estudo anterior da fachada com o projeto final para reforçar a dialética massa-superfície. Inicialmente, a fachada destaca-se do volume interno com cores diferentes. Com isso, em vez de ambiguidade, gera distinção entre superfície no primeiro plano e massa ao fundo. Efeito corroborado por uma entrada lateral cortando o maior plano opaco desta fachada, o que dificulta a leitura deste plano como massa. No projeto final, esse acesso é deslocado, e a fachada é 
aproximada do volume interno, ambos com mesmo tratamento. $\mathrm{O}$ resultado final permite leitura ambígua, pois pode ser lido tanto como massa com partes empurradas pelo eixo externo quanto como sequência de planos transversais a este eixo.

O eixo externo desloca o pátio de sua posição central para o fundo, formando "U". Este "U" é marcado no térreo e no terceiro pavimento, enquanto no primeiro e no segundo pavimento o fechamento do pátio é restaurado. Isso marca a fachada verticalmente com sequência A-B-B-A. Além disso, a fachada acaba por ser dividida em três (leitura tripartida), em ambos os sentidos: na horizontal, pelo "H"; e na vertical, pelo conjunto de janelas à esquerda do acesso, pelo conjunto do acesso e pelo trecho opaco.

O pátio central reforça essa divisão tripartida, marcando as fachadas laterais; no térreo, o deslocamento do pátio central aparece também no tratamento do piso. A divisão tripartida fica clara ao equilibrar os escritórios laterais pelo eixo longitudinal e o escritório ao fundo com volume do acesso pelo eixo ortogonal. "A divisão volumétrica tripartida internamente do edifício cria um efeito de malha, [...] Estas são tratadas como pavilhões em um esquema paladiano" (EISENMAN, 2006c, p. 305, tradução nossa). A divisão da planta em três, tanto no sentido ortogonal quanto longitudinal, reforça a condição centroide ao marcar os cantos. Mesmo esses volumes dos cantos são divididos por regra semelhante, operação recursiva, a adição de elevadores, que forma três planos ortogonais nestes volumes.

As fachadas laterais apresentam flexão mais difícil por não serem afetadas diretamente pelo eixo externo. Consequentemente, elas expressam mais claramente a massa genérica e apresentam o sistema de plano ortogonal ao acesso. As fachadas indicam uma terceira leitura: o edifício amortecendo o vetor externo diagonal resultado de sua localização na praça. Isso reflete no volume Leste tratado, na fachada frontal e posterior, como massa. Diferente da fachada lateral oposta, a fachada lateral sudoeste é a única que não revela a divisão tripartida, reiterando a leitura deste volume como bloco, marcando o meio como vazio e as laterais como massa.

A fachada anterior cumpre papel duplo semelhante ao da fachada frontal. A fachada ao fundo deve marcar o fim do eixo externo longitudinal e ressaltar a qualidade das elevações laterais como planos. Isso é obtido através de mesma leitura do "H" presente na fachada frontal. A presença de duas portas nesta fachada fornece uma leitura fraca, mas presente do eixo longitudinal e do pátio.

A interface desta fachada com a lateral à direita é realizada através de um corte vertical que evita a leitura desta lateral como massa, mantendo a dialética massa-superfície. A justaposição de cheios e vazios formada por este recorte na fachada anterior, junto ao conjunto imediatamente 


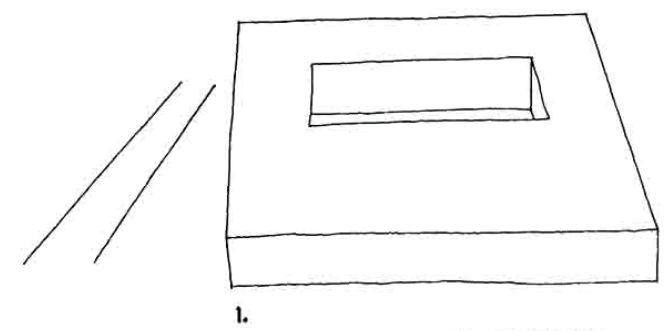

EXTERNAL AXIS PARALLEL TO INTERNAL
GENERIC \&TATE, TTEREEORE RELATIVELD

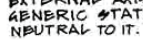

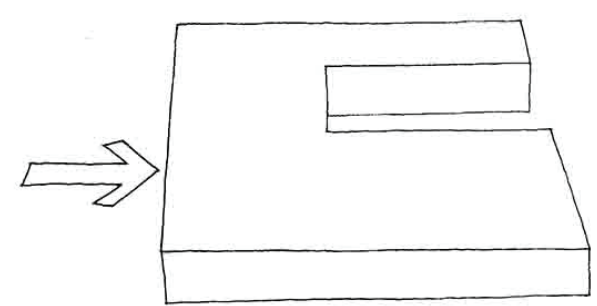

2.

AENERIC U-FORM EVOWVD FROM RESOLUTION

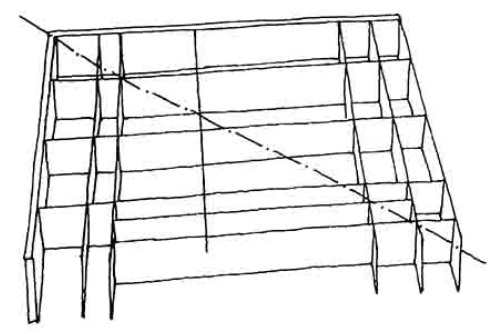

TO COMFENSATE FOR FIRECTIONAL QUALITY TO COMFRN, NW FACADE IS STRESED IN AOCREATE A VOLUMETRIC PLAID. TO AND SE FACADES ARE CONGIDERED AS WEAK.

Figura 55 - Deformação da forma Figura 56 - Planta geral e plano centroide pelo eixo externo e diagonal. horizontal. Fonte: EISENMAN (2006c, Fonte: EISENMAN (2006c, p. 317). p. 320).
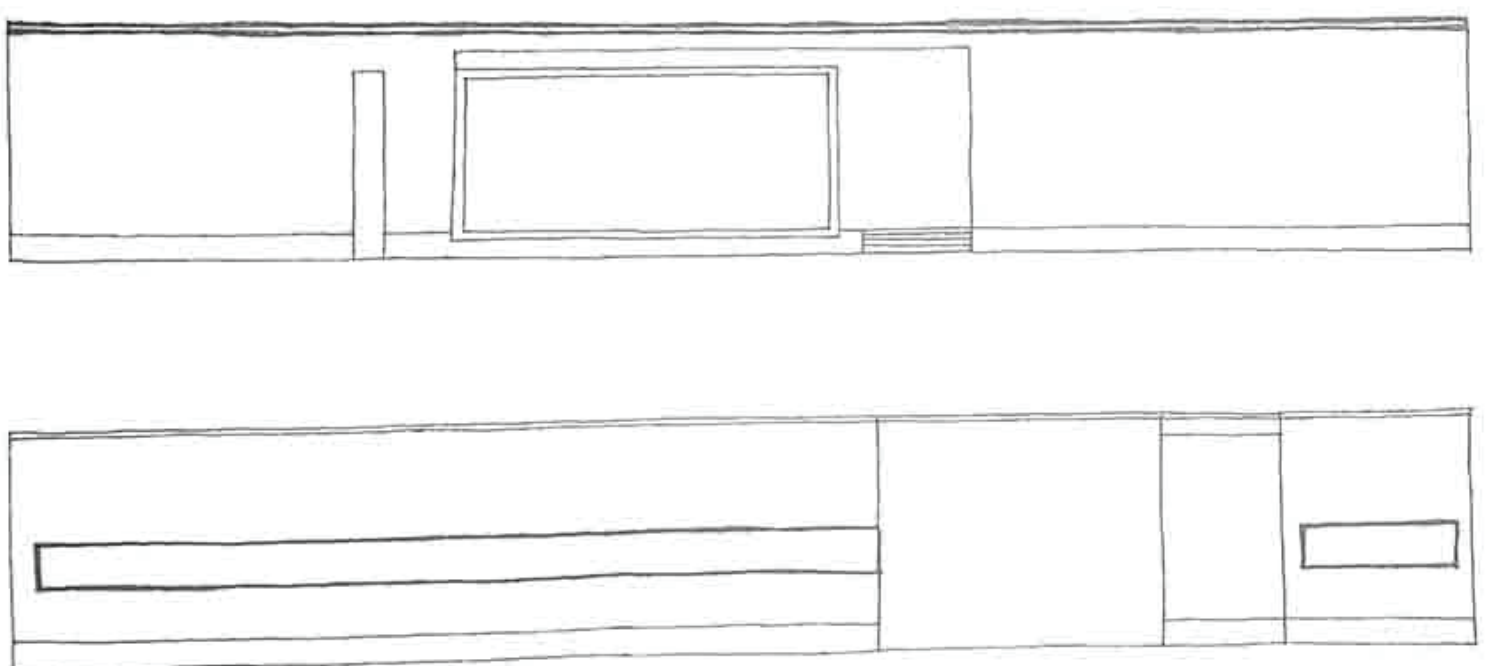

Figura 57 - Plano horizontal marcado na fachada frontal e janela em fita na fachada lateral. Fonte: EISENMAN (2006c, p. 328.) 
ao lado de aberturas e a superfície entre elas, permite leitura de duas dimensóes entre colunas do ambiente interno. Elemento importante nesta fachada é o recorte vertical à esquerda, destacado pela dimensão diferente das demais aberturas, pois é uma grande abertura vertical. Por não ter molduras ou interrupçôes, não é lido como volume, apesar de projetar-se além da fachada, todavia, rompendo a superfície para formar um último plano transversal. Esta projeção junto com patamar da escada forma um quadrado em planta que apresenta a pressão exercida pelo eixo sobre a janela, projetando-a paralela ao plano da fachada ao fundo.

O Asilo Infantile de Terragni, 1937, também está localizado na cidade de Como, na Itália. Porém, seu uso é consideravelmente distinto do projeto anterior, uma vez que se destina a jardim de infância. A relação entre espaços internos e externos é uma decisão progressista para a época em termos de educação infantil, integrando atividades habituais com atividades ao ar livre. $\mathrm{Na}$ análise de Eisenman, o Asilo Infantile é como a Casa del Fascio, um projeto desenvolvido a partir de forma genérica centroide com pátio. Contudo, no Asilo Infantile, não há dialética massa-superfície, não há conflito entre requisitos internos e externos. O eixo externo é paralelo ao edifício. A sintaxe é desenvolvida a partir do acesso único a uma forma centroide, marcando a fachada frontal como plano dominante. Os requisitos funcionais definem uma forma de "U" junto à fachada de acesso. A forma linear sugerida pelo acesso único é contrabalanceada, reforçando uma das fachadas laterais e mantendo as características centroides. Com um plano forte em cado sentido, Terragni forma uma malha e, como estes planos são fachadas, isso resulta em dois lados fortes e dois lados fracos, gerando, portanto, um sistema diagonal.

A diagonal não é compatível com a forma genérica ou com a função. Para negar a diagonal, a fachada frontal é estressada a partir de um corte para o acesso. Esse corte é balanceado na fachada lateral quebrando sua continuidade e enfraquecendo-a também, o que ameniza a diagonal. Mesmo com a diagonal enfraquecida, o sistema volumétrico é desenvolvido a partir destes planos dominantes. O plano que contém o acesso, fachada sudoeste, avança além da fachada lateral sudeste; essa extensão marca em planta o quadrado da forma genérica e destaca a fachada do acesso como superfície.

O sistema utilizado por Terragni tem as dimensóes horizontal e frontal marcadas por planos; e a ortogonal, pelos pilares. Há, na fachada frontal, um recorte que a conecta à fachada lateral dominante, fornecendo leitura da grelha volumétrica. Esse recorte é um pequeno volume com característica de pórtico que conecta o exterior ao pátio interno. Apesar da grelha, a principal referência do projeto é o plano horizontal marcado pela cobertura única, o qual é destacado no tratamento das fachadas, reforçando a leitura de que os volumes são superfícies justapostas. 


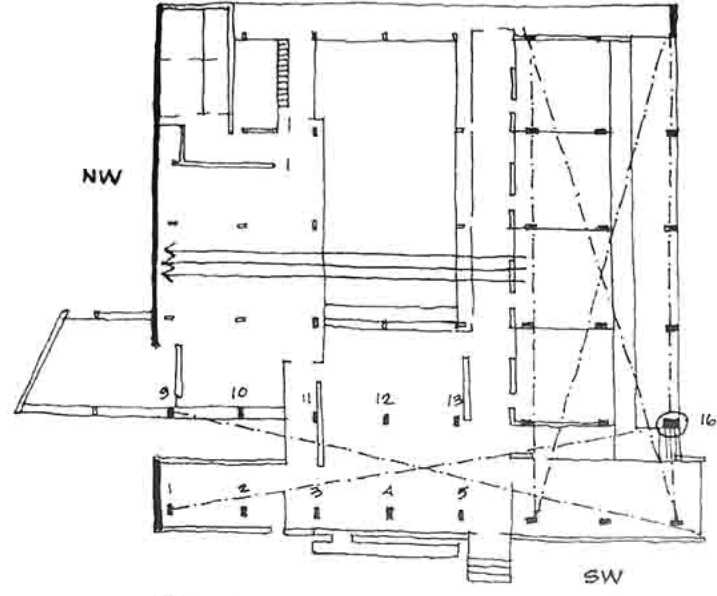

20. INTERPRETATION OF COWUMN I6

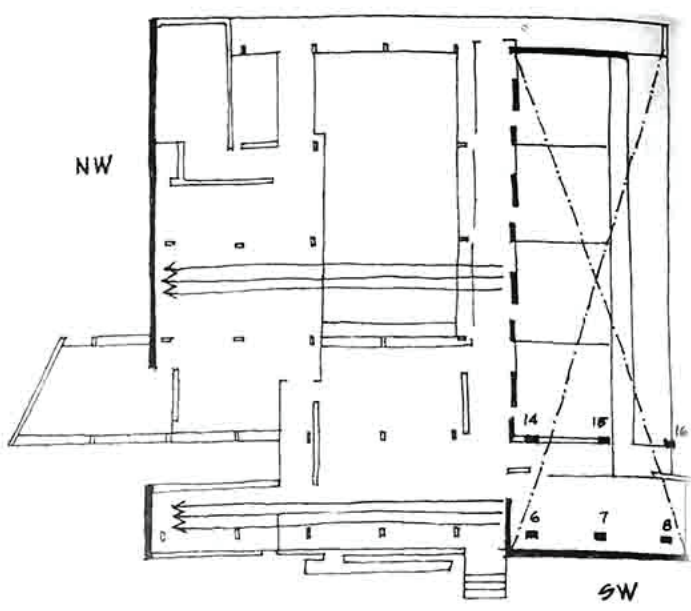

21. RIAHT ARM OF U-FORM TENSIONED

Figura 58 - Pilares da fachada lateral e volume lateral da forma "U". Fonte: EISENMAN (2006c, p. 332).

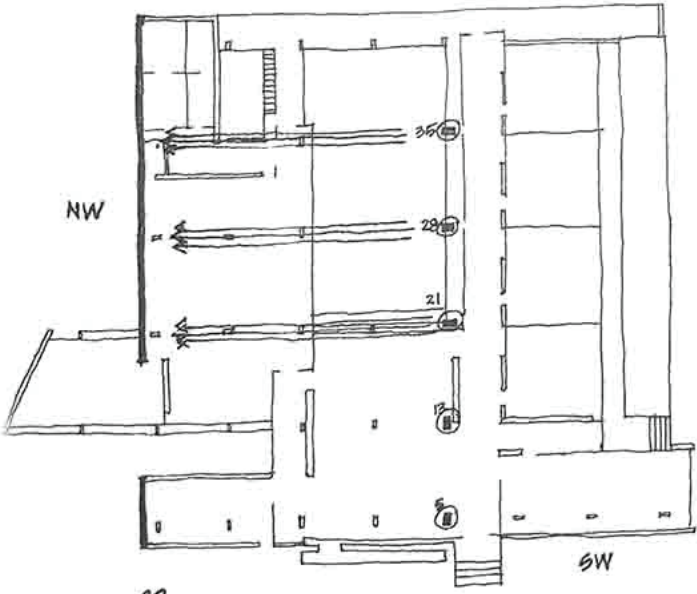

22. INTERPRETATION OF CHANGING DIRECTION OP CENTRAL COUMNS

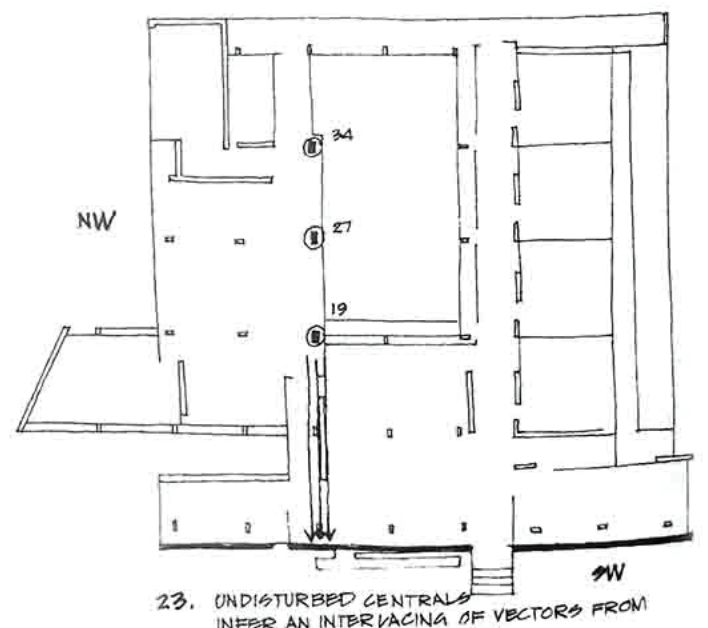

INEER AN INTER VACING OF VEC
THE DOMINANT SURPACES

Figura 59 - Colunas do pátio central. Fonte: EISENMAN (2006c, p. 332).

O sistema ortogonal formado pelos planos de referência nas fachadas fica claro na disposição das colunas. As colunas em forma retangular são elementos direcionais - na forma genérica, elas estariam direcionadas em relação à forma "U”, em direção à fachada do acesso; a forma específica desenvolve-se com as colunas sendo tensionadas por ambos os planos dominantes. A fachada sudeste, como plano fraco, é flexionada pela fachada oposta, a noroeste, plano dominante; seu tratamento como superfície puxada e a direção das colunas junto a ela reforçam a atração exercida pelo plano dominante. As duas sequências de pilares próximos à fachada principal, sudoeste, deveriam estar alinhadas com esta por sua característica de plano mais relevante, pois é a principal parte da forma "U"; no entanto, estes pilares estão alinhados com a fachada noroeste - no mesmo sentido que os demais pilares junto à fachada noroeste -, o que, além de reforçar o plano lateral forte, forma o volume do "U”, o qual tensiona o pátio. 
Estas operaçôes sobre os pilares reforçam a leitura de grelha formada pelos dois planos dominantes. A força destes planos é sucessivamente reforçada e negada, consolidando a leitura da grelha, uma leitura de entrelaçamento. Coluna de especial interesse é a do canto do pátio equidistante dos dois planos, pois, além de garantir a predominância da fachada frontal ao estar alinhada a este plano, ela forma com as colunas adjacentes sequência que quebra o volume da cozinha, impedindo que ele concorra com o plano da fachada de acesso.

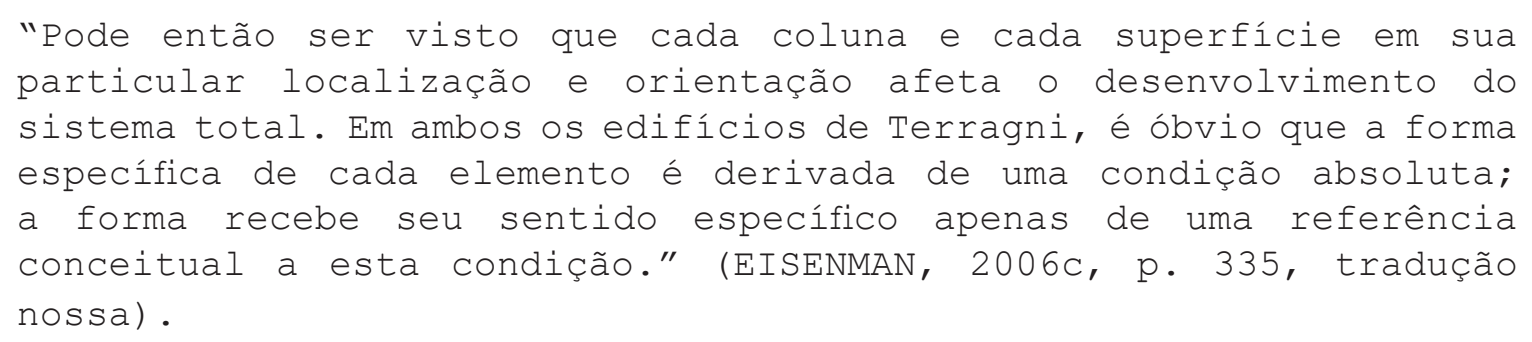

Estas análises de Eisenman permitem que apreendamos o potencial do sistema formal defendido pelo autor. Condizente com a sua postura de teoria aberta, elas propiciam que vejamos como os quatro arquitetos elaboram sistemas formais sensivelmente diferentes sob condiçôes semelhantes, portanto como um sistema que expressa a maneira de elaborar a forma sem determinar o fim é proposta fértil de resultados. Como o sistema proposto por Eisenman parte do requisito formal externo e interno, e estes sugerem basicamente uma forma genérica centroide ou linear, o ponto de partida de um projeto pode ser uma de quatro possibilidades: ambas as demandas lineares, ambas centroides, a interna centroide e a externa linear e a inversa desta última.

Cada um dos arquitetos estudados por Eisenman empreende uma gramática. As obras de Le Corbusier apresentam dialética entre as demandas externas e as internas; as demandas externas são resolvidas por articulaçôes de sistemas de movimento, e as internas articulam sistemas de volumes. Le Corbusier não expressa tensão entre esses dois requisitos diferentes, ao contrário, desenvolve os dois sistemas em paralelo formando síntese. Wright, independentemente de haver conflito entre as demandas interna e externa, não articula um sistema de movimento, desenvolve apenas sistemas de volumes. Aalto, quase oposto a Wright, articula principalmente o movimento, resultando em sistema de volumes subordinado a este. Terragni é semelhante a Le Corbusier, porém não resolve tensão entre as demandas externas e internas com síntese, ao contrário, expressa a tensão entre esses requisitos apresentando o principal exemplo da dialética massa-superfície proposta por Eisenman.

Esses percursos pelas análises também são importantes porque essas quatro gramáticas diferentes trazem operaçôes que encontraremos na House I. Apesar de Terragni e Le Corbusier serem as principais referências associadas a Eisenman, encontraremos diálogos com Aalto e Wright 
também. Da gramática formal de Le Corbusier, Eisenman extrai formas de controle do movimento, como no acesso da Cité de Refuge, o jogo de volumes extraídos de superfícies, mas principalmente o trabalho sobre sequências; tanto a progressão de superfícies de algo mais sólido ao diáfano quanto as sequências que fecham as formas dos projetos serão utilizadas por Eisenman. Este segundo tipo de sequência também é importante, pois traz a necessidade de fechamento da forma e o trabalho com elementos virtuais, como as etapas inferidas nas sequências de pilares ou janelas utilizadas por Le Corbusier. Nas obras de Wright, Eisenman apreende o elaborado jogo de volumes; merecem destaque a dialética entre sistema estático e dinâmico de volumes, que é o jogo simultâneo de justaposição e sobreposição de volumes, e a forma de marcar volumes por notações mínimas, como por quatro pilares, ou par de pilares "puxado" de uma superfície. Também de Wright, há o equilíbrio de elementos em torno de eixos sem que sejam simétricos, mas considerando seu peso e alavanca em relação ao eixo. Eisenman absorve de Aalto o refinado equilíbrio do eixo horizontal, o equilíbrio dinâmico que Wright faz em planta, Aalto faz na elevação; também deste arquiteto que Eisenman obtém modos de lidar com espirais: o travamento deste sistema através de um pátio, a resolução de uma espiral centrípeta colidindo-a com o centro e as deformaçóes assimétricas que a espiral exerce sobre o volume edificado. Terragni, talvez, traga as principais referências para Eisenman, particularmente a Casa del Fascio; como este projeto, Eisenman utiliza: o cubo como antecedente genérico; a planta quadrada dividida em três nos dois sentidos, o diagrama dos nove-quadrados; a dialética massa-superfície e sua resolução através de sequência frontal de planos; e o cubo genérico cortado na vertical por eixo linear externo. Conforme analisarmos a House I adiante, veremos que as características extraídas das análises de Eisenman fornecerão importantes ferramentas para lermos o projeto do arquiteto, bem como o resultado da leitura da House I revelará movimentos como dos projetos analisados neste capítulo.

\subsection{Estrutura Profunda e arquitetura conceitual}

Como vimos, a Tese de Eisenman, The Formal Basis of Modern Architecture (EISENMAN, 2006c), apresenta as primeiras questôes e referências do arquiteto, os principais arquitetos que Eisenman lê - Le Corbusier, Terragni e Palladio ${ }^{20}$ - e um modo de apreensão da forma. Essas

20 Palladio aparece ao Eisenman como uma referência mais discreta - lido por Wittkower, chega a Eisenman mediado por Colin Rowe. Palladio é referência importante em sua leitura por ser figura que apresenta a relatividade do moderno, por meio de Rowe, e pelos diagramas de leitura, oriundos de Wittkower, o nine-square. Palladio é uma constante na carreira do arquiteto - em 2015, publica livro oriundo de exposição que faz sobre leituras dele, Palladio Virtuel. Em seu livro Diagram Diaries, Eisenman (1999) explicita sua referência nesta fase a 84 
consideraçôes passam por revisôes conforme Eisenman desenvolve suas ideias no final da década de 1960 e início da década de 1970. A referência à linguagem ganha força concomitantemente ao alinhar seus desenvolvimentos à linguística de Noam Chomsky; consequentemente, a partir de concepçóes estruturalistas, Eisenman agrega os conceitos de estrutura profunda e aparente para rearticular o par genérico e específico. A percepção presente principalmente em sua análise de Terragni, sobretudo da dimensão sintática da arquitetura como a ordem das regras da forma, leva à cisão da ideia de ambiente total, a remoção da presença de referências externas, a um aprofundamento da abstração.

Sua Tese foi apresentada em agosto de 1963. No mesmo ano, em outubro, publica o texto Towards an Understanding of Form in Architecture (EISENMAN, 1963). Apesar de a estrutura como um todo permanecer, comparando a forma como Eisenman expóe alguns pontos nestes dois textos sugere exploraçóes do arquiteto. Na Tese (EISENMAN, 2006c), antes de partir do projeto para o que lhe é externo, Eisenman explora situação do edifício concebido a partir do que é interno:

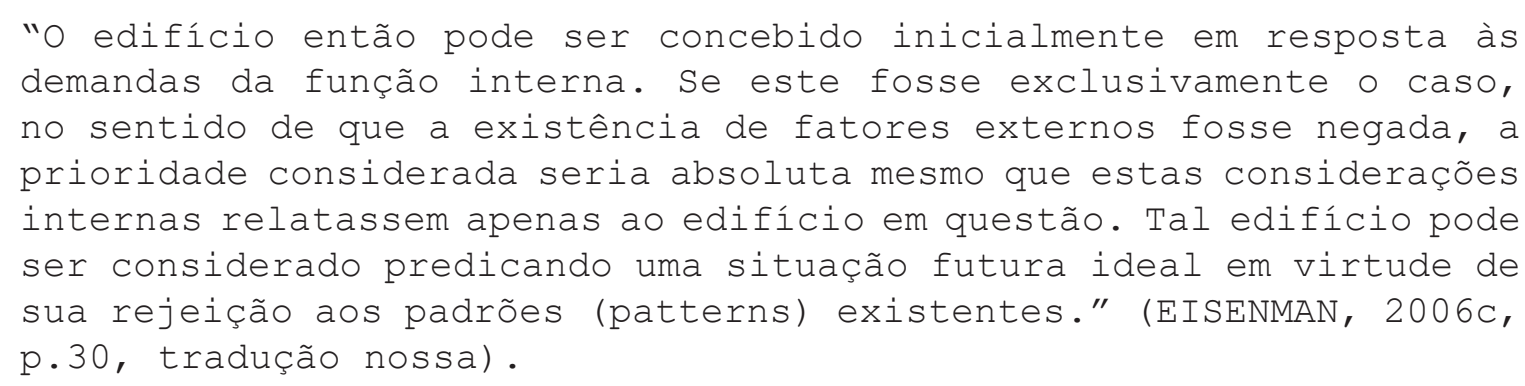

Em um exercício que nega o ambiente descreve um edifício autônomo a partir de questôes internas, um absoluto a partir de si, um edifício autorreferente. Na Tese, Eisenman não avança neste caso porque náo contribui a uma ordenação do ambiente total. No seu texto Towards an Understanding of Form (EISENMAN, 1963, p. 458-459), começa a colocar com maior peso a referência no próprio projeto. Ao falar da demanda do ambiente, da intenção e função, estas últimas não aparecem subordinadas ao ambiente de forma categórica, mas os dois termos são articulados pela conjunção "ou”. O protagonismo tautológico do ambiente total passa a ceder à possibilidade da ordem interna, do próprio projeto como protagonista.

Podemos destacar na Tese dois grandes movimentos que percorrem a carreira de Eisenman: a busca de compreender a arquitetura de forma menos determinada possível, sem sentidos prédefinidos, e a intenção de formatar teoria aberta, menos carregada de definiçôes, menos restritiva aos fins. Neste momento, é sua busca de resgatar o lado crítico, conceitual da arquitetura, frente ao histórico e técnico, a procura por modo de atuar não afetado por questôes transitórias, específicas, portanto, aquilo que é próprio à disciplina, sua possibilidade de autonomia, o que na Tese 
denomina crítico, que deve ser lógico e genérico. Seu percurso, dessa maneira, segue este processo de limpeza, colocando suas próprias categorias em suspeita, caso identifique que sejam restritivas, pré-determinadas.

Além do já citado Towards an Understanding of Form, os principais textos que encontramos após a Tese são os da exposição que Eisenman faz da House I e House II, publicados no livro Five Architects (EISENMAN et al., 1975), resultado do sétimo CASE, de 1969; o texto Dall'Oggetto alla Relazionalità (EISENMAN, 1970a), publicado na revista Casabella em 1970; o texto Notes on Conceptual Architecture: Towards a Definition (EISENMAN, 1970b), também de 1970; e From Object to Relationship II, de 1971 (EISENMAN, 1971). A partir desse conjunto, temos definição de sua posição teórica no início das Transformaçôes, sua arquitetura conceitual. O título do texto Dall'Oggetto alla Relazionalità acusa importante mudança em relação à Tese: o foco deixa de ser o objeto para ser as relações. Neste texto e no From Object to Relationship II, retoma a análise da Casa del Fascio aprofundando a perspectiva da operação formal como operação predominantemente sintática. A forma da leitura, os diagramas, a compreensão do espaço como volumes positivos e negativos permanecem, mas o resultado difere.

Alinhado à perspectiva histórica da Tese, visa à continuidade do projeto moderno, justificando que a progressão da técnica e da abstração enseja um projeto inacabado. A justificativa técnica é semelhante a como apresenta em sua Tese: graças aos avanços tecnológicos, a arquitetura pode desmaterializar-se, compreende, então, o projeto de Terragni como um não objeto (EISENMAN, 1970a, p.41). No projeto da Maison Dom-Ino, de Le Corbusier, as novas tecnologias marcam desvínculo de limitaçôes pragmáticas para estabelecer vínculo com limitaçôes semânticas; suas formas representam o mundo industrial, são extraídas de outros meios, aviōes, barcos, silos. Na perspectiva de Eisenman Terragni apresentaria com a Casa del Fascio um passo seguinte: mudança do domínio semântico ao sintático, compreendida como relações formais em nível conceitual (EISENMAN, 1970a, p.38). O argumento de Eisenman sofre alteração: permanece que a arquitetura moderna ainda não se realizou, mas agora não por inverter a ordem retirando a primazia da forma em favor da técnica e história e por não dar clareza ao ambiente, mas por não levar adiante o potencial da sintaxe, da abstração. No texto From Object to Relationship II, Eisenman (1971) apresenta artistas modernos, Malevich, Lissitzky e Fernand Leger, como exemplos de uso da abstração para retirar os objetos de seu sentido tradicional e permitir a formaçáo de novos sentidos. Leger, por meio da colagem, investe material do mundo com outros sentidos ao mudá-los de contexto. ${ }^{21}$ Eisenman

21 Neste momento, Eisenman não considera esta opção, mas é muito próximo ao scaling, ferramenta de 
considera mais interessante Malevich, Lissitzky, os quais procuram fazer um novo mundo de objetos puramente de relações formais, abstratas. A intenção do arquiteto não é eliminar o objeto ou o sentido, mas deslocar os sentidos condicionados, pré-determinados, em busca de outros sentidos (EISENMAN, 1971, p.38-40). Será a partir do deslocamento de sentidos tradicionais, por meio da abstração, que Eisenman encontrará a ambiguidade como ferramenta transformacional, um modo de deslocar o foco do aparente para o conceitual.

Como suporte ao recorte do sintático, Eisenman utiliza a linguística de Noam Chomsky ${ }^{22}$. O arquiteto compreende a arquitetura como linguagem, podendo ser lida a partir de três princípios: pragmática, relação da forma com técnica ou função; semântica, relação da forma com sentido e iconografia; e a sintática, a forma como o sentido é mediado (EISENMAN, 1971, p. 39). Adota a divisão de Chomsky de que há duas estruturas, uma profunda, de caráter conceitual, e uma aparente, de caráter perceptivo. A estrutura aparente é aquilo que pode ser apreendido pelos sentidos, material, textura, cor, forma do objeto, ${ }^{23}$ enquanto a estrutura profunda enseja respostas conceituais, elaboradas por processo mental, como frontal, oblíquo, recessão, alongamento, compressão, cisalhamento; esta estrutura não lida com a presença física dos objetos, mas com a relação entre eles.

A totalidade presente na Tese - em cujo sistema proposto os diferentes elementos se interrelacionam de forma estruturada e hierarquizada em uma mesma cadeia, da forma à técnica é cindida. Diferente do exposto na Tese na qual a sintaxe organiza o vocabulário em nome da clareza do ambiente total, na qual a forma é articulada como um todo, agora a sintaxe dá ordem à própria ordem; Eisenman dirá que o contexto é sintaxe (EISENMAN, 2004b, p. 16), e ela adquire autonomia frente ao semântico. A função, encarada na tese com papel importante na constituição da forma, agora é entrave, é uma questão pragmática, a função é então desvinculada da sintaxe. No texto Notes on Conceptual Architecture: Towards a Definition (EISENMAN, 2004b), aponta que o objetivo do projeto é comunicar o conceito da arquitetura, transmitir a partir da estrutura aparente a ordem da estrutura profunda. O título do texto Notes on Conceptual Architecture guarda relação com o texto do artista conceitual Sol LeWitt, Notes on Conceptual Art. Eisenman está dialogando com a arte conceitual. O que descreve na Tese como intenção, o conceito de algo, a ideia inicial do sua segunda fase, as Decomposições.

22 Além de fazer referência direta a ele no Dall'Oggetto alla Relazionalità (EISENMAN, 1970a), o faz no texto Notes on Conceptual Architecture (EISENMAN, 1970b). No From Object to Relationship II (EISENMAN, 1971), cita o ano de 1966 como sendo a data na qual tece contato com as ideias do filósofo.

23 A tradução para português gera confusão: em relação à "estrutura aparente", Eisenman utiliza o termo "shape", enquanto ao falar de "forma", no sentido conceitual, utiliza o termo "form". Porém, ambos os termos são traduzidos geralmente como "forma". 
projeto, passa a ser o conceito da própria arquitetura (EISENMAN, 2004b, p. 15). O conceito de casa não é conceitual, conceitual é o conceito de conceito, arquitetura de arquitetura, a forma da forma; formulação como a do artista conceitual Joseph Kosuth, segundo o qual a arte é definição de arte. Eisenman passa da referência a algo externo, a ordem total, para algo interno, autorreferente, o conceito da arquitetura.

Eisenman propõe que a internalização do contexto, arquitetura autorreferente, é passo adiante em relação a Terragni. Diferente da leitura que faz do arquiteto em sua Tese, na qual as relaçóes encontradas nas fachadas refletem nos espaços internos, Eisenman verá este projeto como relaçóes formais voltadas ao contexto. As análises que Eisenman faz da Casa del Fascio ilustram a mudançą ${ }^{24}$ - se na Tese compreende este projeto como uma unidade em que o interno e o externo se interrelacionam, quando retoma a análise da Casa del Fascio mostra primeiro o plano como um quadro, trazendo os elementos internos para o plano da fachada (EISENMAN, 1970a). Dívida de Eisenman em relação à sua leitura de Rowe e Slutzky, o arquiteto lê a fachada principal da Casa del Fascio como um plano que condensa as relaçôes com os diferentes planos atrás deste. Atrelado à frontalidade do plano, conceito de um eixo que organiza sequência de planos sobre uma superfície, ${ }^{25}$ Eisenman o lê como a transparência fenomênica, lida pelos autores a partir do cubismo, no qual o plano transparente achata uma sequência de outros planos (ROWE; SLUTZKY, 1963). No segundo momento, não a apreende com a mesma unidade entre o interno e o externo, dirá que as articulaçóes ficam no plano da fachada, não atingindo o espaço interno, e que suas relaçóes são orientadas ao contexto (EISENMAN, 1971, p. 51). A Casa del Fascio não é, então, autorreferente, sua estrutura conceitural está atrelada ao meio.

A estrutura profunda, a autorreferência, reflete mudança na compreensão de Eisenman da autonomia da arquitetura. Em sua Tese (EISENMAN, 2006c), compreende categorias próprias à arquitetura - a forma, o volume, a apreensão de um todo em uma experiência temporal - que

24 Para essas sucessivas releituras, Eisenman (EISENMAN, 1970a, p. 38) cita Barthes (BARTHES, Roland. The activity of structuralism. Form, Cambridge, n. 1, 1966, p. 12-14.), para o qual "a atividade do estruturalismo é pegar a realidade, decompô-la e recompô-la novamente.", processo no qual gera algo novo, algo do intelecto adicionado ao objeto (EISENMAN, 1970a, p.38, tradução nossa). Ele continua no caminho da Tese, de teoria aberta, o que ele faz não é reconstituir ou atestar que o que ele analisa é, mas é uma leitura dele, uma leitura que produz. Eisenman é criticado porque sua leitura de Terragni não é o arquiteto, mas uma construção sua dele, o Terragni de Eisenman. Eisenman aceita isso e reconhece, tanto na Tese quanto agora, que não está afirmando as teses desses arquitetos, mas uma leitura sua deles. Processo que não limita o fim, não tem uma conclusão clara, teoria aberta.

25 Operação em relação complementar e inversa a que vimos Eisenman identificar na Casa del Fascio em sua Tese. Nesta, o eixo externo atinge a forma genérica do cubo e a distorce em sequência de planos ortogonais ao eixo os quais expressam sua característica linear, amortecem o eixo e marcam plano de referência às demais distorções. A operação da transparência faz o oposto: sintetiza sequência de planos em um plano frontal, forma a partir deste ponto de vista plano virtual composto pela sequência de planos. 
operam em favor de uma ordem além da arquitetura. A arquitetura existe no ramerrão do dia a dia, ela visa dar ordem à experiência do sujeito. Agora, volta a arquitetura sobre si mesma, sua referência de ordem passa a ser a estrutura que ordena o próprio projeto, autorreferente. A internalização da ordem total é a estrutura profunda. Diferente da ordem total, um absoluto externo, do genérico como ideal platônico, irrealizável, a estrutura profunda está lá, latente. Ela internamente ordena o processo da forma. Ocorre inversão, em vez da ordem total que ordena o ambiente para facilitar a compreensão do sujeito, este deve observar a forma e, por processo de apreensão mental, compreender a estrutura profunda, interna ao projeto.

A forma, que na Tese compóe um todo com o ambiente, é flexionada para uma síntese das demandas genéricas e específicas, passa a ter dois planos que operam de forma dialética, a estrutura profunda e a estrutura aparente. Como vimos, na Tese, utiliza os termos conceitual e perceptivo subordinados ao genérico, ao ideal, e ao específico, ao material. O específico é uma imagem do genérico, e ambos participam de uma ordenação hierárquica na qual o específico almeja o genérico. Neste momento, compreende o conceitual e o perceptivo como duas estruturas paralelas, a estrutura profunda e a estrutura aparente, respectivamente; como vimos também, estes são conceitos que extrai da linguística de Noam Chomsky. Autônomas, as estruturas são irredutíveis uma à outra ${ }^{26}$, relacionam-se de forma dialética. Diferente da postura da tese do real como a instância atual do ideal, ambas as estruturas, perceptiva e conceitual, coexistem. $\mathrm{O}$ abandono da hierarquia platônica talvez seja motivo de não mais utilizar os termos genérico e específico; a forma como descreve uma das fachadas da Casa del Fascio mostra consequência desta diferença - compara a parede "pura" a uma tela à espera do trabalho, de ser marcada pelas relaçóes da forma. É o inverso do sistema de genérico e específico, no qual a parede final estaria flexionada almejando retornar à condição de "pura”, o estado genérico (EISENMAN, 1970a, p.41).

Tal como na Tese, que a noção de genérico e específico opera de forma recursiva em todas as instâncias, as duas camadas desta nova estrutura, a perceptiva e a conceitual, sofrem cisão parecida, possuindo sintaxe e semântica. Eisenman compreende essas duas categorias como diferentes modos de ordem - a sintaxe é ordem de elementos não codificados regidos pela relação, já a semântica é ordem de elementos codificados, é representativa. O que na Tese eram articulações volumétricas, o estático e o dinâmico, justaposição e interpenetração, tornam-se os modos do semântico e do

26 Por esta via, faz crítica a Sol LeWitt (EISENMAN, 2004b). As estruturas do artista, suas formas cúbicas, procuram transmitir conceitos, mas os materializam sem considerar as características da estrutura aparente; assim, acaba o perceptivo por representar o conceitual. Eisenman defende que mesmo a estrutura aparente deve ser encarada a partir de suas características (EISENMAN, 2004b, p. 14). 
sintático, respectivamente. Com isto, é possível haver em ambas as estruturas organizaçôes mais rígidas, semânticas nas quais há elementos codificados justapostos, ou mais abertas, sintáticas com elementos não codificados que se interpenetram.

A partir dessas divisões das estruturas profunda e aparente, são possíveis três combinaçôes a partir de qual ordenação prevalece em cada estrutura: quando a estrutura conceitual é semântica; quando ela é sintática com a estrutura perceptiva semântica; e quando ambas são sintáticas. Com o conceitual semântico, a estrutura conceitual é representativa de um conceito. Quando o conceitual é sintático e o perceptivo semântico, a materialização é representativa de uma ordem relacional. Quando ambos são sintáticos, eles operam como duas ordens relacionais paralelas (EISENMAN, 2004b, p. 22-23). Eisenman compreende Le Corbusier como operando com estrutura profunda sintática, mas a partir de uma estrutura aparente semântica, consequência de operar uma metáfora por meio do "Estilo Internacional", a representação de formas industriais. Nesta categoria, Eisenman também vê o artista conceitual Sol LeWitt, uma vez que suas formas representam malhas conceituais sem respeitar as condições de materialização delas (EISENMAN, 2004b). Terragni estaria trabalhando ambas as estruturas em termos sintáticos. Eisenman diz que "as formas brancas e exatamente delineadas, que lembram modelos de plástico, de papelão, não são apenas metáforas semânticas" (EISENMAN, 1970a, p. 38, tradução nossa) - edifício deslizar entre construção e modelo sugere descarga do conteúdo semântico pela ambiguidade, a ferramenta do deslizar de sentido que impede sua fixação. Encontra em Terragni esta ferramenta, a qual utilizará em suas primeiras casas, ao ponto de chamá-las de "arquitetura de papeláo"27.

Ambas as estruturas sintáticas serão sua proposta de projeto, compreende este como modo menos carregado de sentidos pré-determinados, culturalmente condicionados. O sintático, com o trabalho de relaçóes entre elementos formais, permite novas expressóes, novos significados pela manipulação da forma e do espaço, diferente do semântico que, como justaposiçáo de elementos com sentido pré-determinado, opera significados pela representação (EISENMAN, 2004b, p. 24). A forma da forma, a estrutura da estrutura, sintaxe da sintaxe, permitiria a manipulação do significado da forma. Eisenman explora a ferramenta da ambiguidade como forma de desestabilizar os significados definidos em busca de novos significados. Extrai definição de ambiguidade de William Empson, para quem ela é a tensão entre o denotativo e o conotativo, a qual traduz como tensão entre o superficial e o profundo. Deste modo, a estrutura profunda pode informar ambientes físicos específicos em

27 Ao ponto de denominar texto sobre as primeiras quatro casas com este nome Cardboard Architecture (EISENMAN, 1973a). 
vez de representar elementos diversos (EISENMAN, 1971, p. 41). Em outras palavras, por meio desta tensão da abstração, os aspectos profundos fornecem estruturas para significados implícitos em oposição a significados explícitos (EISENMAN, 1971, p. 39).

A concepção das duas estruturas depende da noção de que há uma dimensão real e uma virtual na arquitetura. Por meio desta distinção, desvincula o ideal e o perceptivo - forma genérica e forma específica - como duas faces de um fenômeno, articulados em paralelo como estrutura profunda e estrutura aparente. Apesar da referência ao texto de Colin Rowe e Robert Slutzky (1963), Transparency: Literal and Phenomenal, ser de onde extrai esta noção, Eisenman traça importantes diferenças que reforçam a ênfase no sistema de relaçóes em vez de no objeto. Eisenman diz que Rowe e Slutzky entendem que o sentido da forma vem da contradição, na dimensão espacial, entre o espaço real e o implicado, enquanto ele diz que o sentido vem do controle desta relaçáo, de operar a dialética entre estrutura profunda e aparente. A segunda distinção é que, para Eisenman, a ambiguidade não necessita estar no espaço de fato, mas na interpretação conceitual da relação entre os objetos (EISENMAN, 1971, p. 61).

Condizente com a proposta de procurar uma teoria aberta, essa guinada no pensamento de Eisenman permite que alguns conceitos presentes na Tese adquiram condiçóes menos determinadas. Um ponto é que implica mudança no produto, no resultado do projeto. A ordem total demanda um objeto que a compóe, que participa de um todo único, e a forma torna-se necessariamente um objeto construído. Quando opera a partir das duas estruturas irredutíveis uma à outra, a estrutura aparente como materialização a partir de uma estrutura profunda, como ordem sintática, de relaçôes, não precisa ser uma construção, mas algo que a implica, algo perceptivo - desenhos, maquetes, diagramas, etc. - com suas próprias características. Estrutura aparente não lida com a presença física dos objetos, mas com a relação entre eles (EISENMAN, 1971, p.39). A estrutura aparente e a profunda geram relações que não se resumem às formas no ambiente total, mas a um sistema formado por conjunto de notaçôes do qual as mais diversas instâncias participam. ${ }^{28}$

Alguns conceitos da forma adquirem nova interpretação. Eisenman direciona a relação conceitual ao próprio projeto, ou seja, passa a internalizá-la, dialoga com a ideia de fechamento presente na Tese, com a questão da unidade. A procura por fechamento formal, como patente nas análises de Le Corbusier, é rebatida na estrutura profunda como fechamento das relaçóes, o

28 Em 1980, Eisenman publica o texto Aspects of Modernism: Maison Dom-Ino and the Self Referential Sign (EISENMAN, 2014a), no qual lê a Maison Dom-Ino de Le Corbusier como diagramas autorrefentes, em vez da forma ordenada com a forma genérica, um conjunto de referências circulares entre projeto, desenhos e edifício por meio de notações. Reiterando o ponto de que a leitura que Eisenman realiza de outros arquitetos se desenvolve junto às suas considerações; não só Terragni, também Le Corbusier passa por releituras. 
projeto faz referência apenas a si mesmo, é autorreferente.

Outra questão é a frontalidade. Tida até então como característica não questionada, passa a compor um binômio. As leituras da Tese articulam as formas sempre a partir das fachadas como planos, mas principalmente a particular de um plano principal articulador, ou os planos de referência nos eixos ortogonais entre si. Frontalidade como referência tradicional da arquitetura fica clara particularmente nas leituras de Le Corbusier, quando cita o neoclassicismo da composição articulada a partir da fachada frontal e anterior, e Terragni, na Casa del Fascio, articulada pela fachada principal (EISENMAN, 2006c). O frontal agora é colocado em relação, participa de binômio com o oblíquo. No texto From Object to Relationship II, o arquiteto analisa a Casa Giuliani Frigerio, de Terragni, projeto de sistema formal semelhante ao da Casa del Fascio, com a diferença que a principal articulação está nas quinas, é um projeto de apreensão oblíqua (EISENMAN, 1971, p. 51). Diferente da frontalidade, que sugere qual o plano preferencial de apreensão da forma, este binômio sugere qual a posição preferencial, amplia o número de possíveis relações entre o sujeito e o plano que apreende.

A diagonal também adquire outro sentido e é exemplo relevante de como estas mudanças afetam o sistema formal de Eisenman. Ela é vista na Tese diretamente relacionada a elementos externos, seja consequência de acessos, seja como fruto da tensão de dois lados, condição, em geral, resultado de uma fachada forte pelo acesso e uma fachada lateral também forte para articular grelha, como no caso do Asilo Infantile. O projeto autorreferente não possui determinante externo. É a partir da possibilidade de dois lados formarem a diagonal que é possível compreender a diagonal neste novo momento. A condição de dois lados tensionados juntos direciona a leitura para a quina, neste caso a diagonal é o oblíquo. Retomando a leitura da Casa del Fascio, este projeto é frontal, visto que suprime o oblíquo da diagonal da praça, enquanto a Casa Giuliani Frigerio é oblíquo, pois, independentemente do local não sugerir diagonal, a leitura do sistema formal é predominantemente pelas quinas articuladas (EISENMAN, 1971). 
$\bigcirc$

E

[I]

E-1

$\mapsto$

D

O

$\frac{1}{4}$

$\sum_{\text {至 }}^{\text {垈 }}$

U

$\mapsto$

[I]

$m$ 


\subsection{House I, o desenho da teoria: estrutura profunda e autonomia autorreferente}

Eisenman apresenta o projeto da House I como primeiro de sua série das Transformaçôes, como um projeto de sua arquitetura conceitual. A partir do que expóe deste projeto, o texto e as imagens que acompanham a publicação do Five Architects (EISENMAN et al., 1975), auxiliado por ferramentas de leitura da forma expostas em sua Tese (EISENMAN, 2006c), podemos analisar este projeto como forma autorreferente, como expressão de sua arquitetura conceitual. Eisenman busca fazer um anexo para abrigar coleção de brinquedos que é denominado casa, mas não é casa nem museu. A House I, a partir da noção de arquitetura conceitual, procura transmitir o conceito que é seu próprio processo de feitura. Não é uma representação de um conceito, é o próprio conceito.

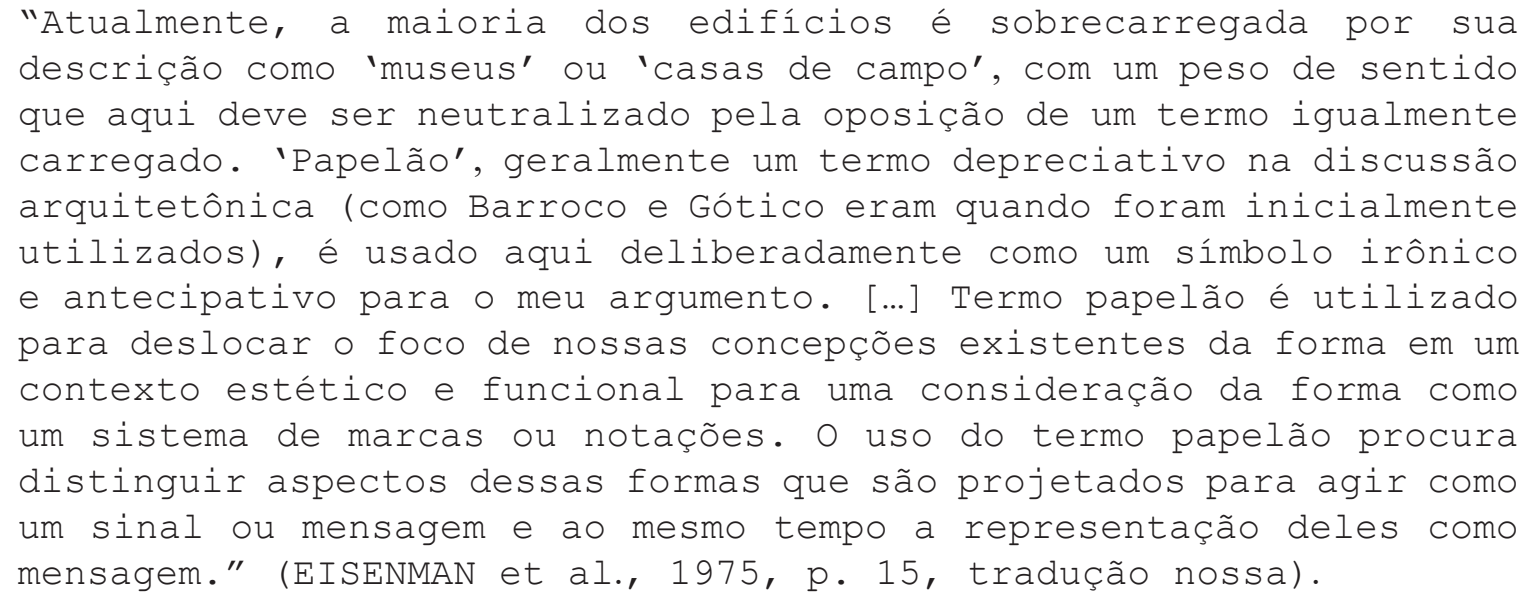

Arquitetura de papeláo (cardboard) é a maquete de seu processo de feitura, de relaçôes. Com isso, Eisenman procura afastar a função e os sentidos estabelecidos em nome de explorar as relaçóes da forma. O arquiteto descreve a House I não a partir de vetores externos ou demandas internas, funcionais, como seria a partir das bases formais que expóe em sua Tese, mas como o exercício de uma diagonal. Como anteriormente explorado, a diagonal percorre diferentes pesquisas de Eisenman: há parte em sua Tese que dedica à exploração do desenvolvimento de sistemas de uma diagonal em um cubo (EISENMAN, 2006c, p. 177-125), está presente nas análises que fez do Säynätsalo Civic Center de Aalto, da Casa del Fascio, do Asilo Infantile e da Casa Giuliani Frigerio de Terragni. Além dessas, encontramos o mesmo movimento inicial da House I em exercício que Eisenman propunha a alunos em Cambridge: o estudo da hipótese de uma diagonal em um cubo (IZAR, 2015, p. 62). Diferente do ambiente total, que não aceita o arbitrário, Eisenman gera a diagonal a partir de uma motivação arbitrária, sem uma referência externa, é uma estratégia, uma intenção de gerar a estrutura dual:

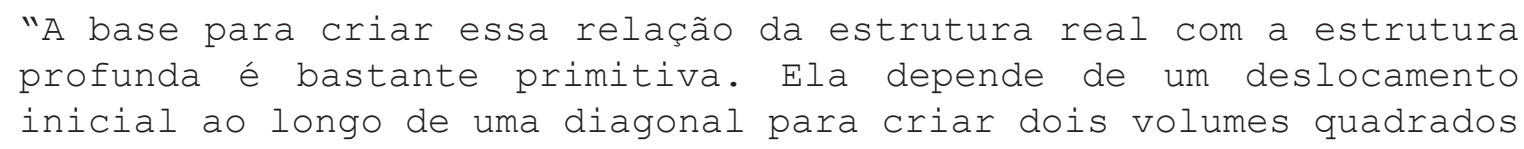




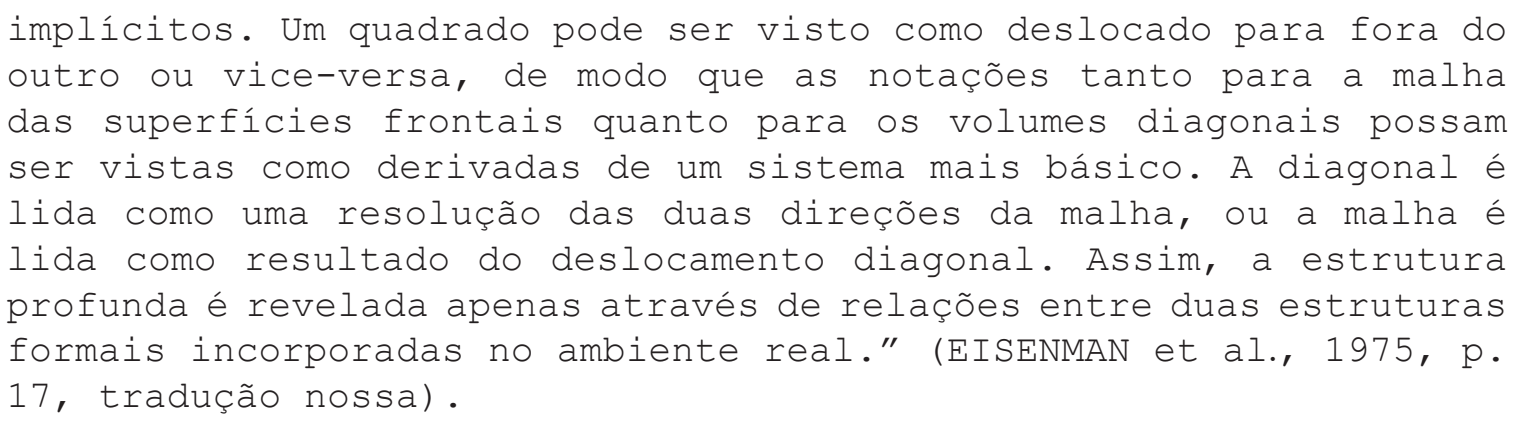

Sendo a diagonal a estrutura profunda, Eisenman descreve a estrutura aparente náo como um ambiente ordenado, mas algo claro por si, cujas referências deslizam entre motivação e resultado. A forma inicial marca essa cisão do meio - é uma forma centroide, um cubo, é forma originada de uma condição externa neutra, uniforme em todas as direçôes. As operaçôes de transformação ocorrem a partir de duas estruturas internas ao cubo, um sistema de planos verticais a partir da fachada e outro de volume a partir da diagonal. A ambiguidade presente no trabalho de Eisenman não define se a diagonal forma a malha ao "deslocar" a sequência de planos ou se a malha forma a diagonal. Contudo, o importante não é a gênese tampouco a possibilidade de uma síntese, mas as estruturas formais que permitem apreensão da estrutura profunda a partir de suas relações. Como vimos, é intencional que não haja síntese, que não fixe uma leitura, pois é uma característica importante de Eisenman a ambiguidade ou dialética, o duplo cujos elementos não se reduzem um ao outro, que possuem autonomia, mas que se interpenetram.

Eisenman trabalhar a partir de malha permite que o conectemos a referências que mobilizou até então: os projetos de Le Corbusier e Terragni, cujas leituras apresentam dialéticas massa-superfície mais elaboradas - principalmente a Casa Del Fascio - e o diagrama nine-square. Diagrama de um quadrado dividido em nove quadrados menores iguais que Eisenman encontra nas leituras que Wittkower ${ }^{1}$ faz de Palladio, dos exercícios pedagógicos propostos por John Hejduk², e que é o quadrado tripartido em planta em ambos os sentidos que Eisenman encontra em Terragni. Esta divisão permite a estratificação de planos a partir da fachada frontal, como a Casa del Fascio. Os diagramas isométricos permitirão ver esses planos e a leitura deles sobrepostos, como transparências, o "baralho de cartas", como denomina na Tese quando associa essa composição de planos sobrepostos à dialética massa-superfície. Ao mesmo tempo que é sequência de planos, o volume da House I também é massa corroída.

Retomando a descrição que Eisenman faz da House I, o arquiteto apresenta a estrutura aparente

1 Uma análise da gênese dos diagramas de Eisenman nos diagramas de Wittkower, mediada pela compreensão de Colin Rowe, pode ser vista em Izar (2015, p. 71-101).

2 Quanto à relação de Eisenman com as propostas de Hejduk, ver as discussões de Hays em seu Architecture's Desire (2009) e a tese de Izar (2015). 
deste projeto como a sobreposição de duas estruturas diferentes: um sistema de planos e outro de volumes. As principais notaçóes que utiliza para marcar os planos são as colunas e vigas. Este modo de marcar volumes por meio de pilares, de marcaçóes em paredes, com elementos que inferem a delimitação do volume, remete diretamente as leituras de Wright que Eisenman desenvolve em sua Tese. No projeto de Eisenman pilares quadrados e vigas servem como resíduos de planos em duas direçôes, ortogonais entre si; já as colunas redondas marcam intersecção entre dois planos - a forma redonda impede que sejam apreendidas como o fim de um plano. Esta seleção entre pilares quadrados e colunas redondas poderia ensejar uma conotação semântica, mas a escolha advém de características da forma. A seção quadrada é formada a partir de quatro planos verticais ${ }^{3}$, elementos lineares que direcionam ou bloqueiam o sentido; a seção redonda, por sua vez, é expansiva em todos os sentidos, não limitando o sentido a um plano.

Pilares e vigas são elementos da estrutura aparente cuja referência à estrutura profunda se dá pela transformação desses elementos em notaçôes. Tornam-se notação por processo de minimizar ou eliminar sua carga semântica, eles marcam a grelha independentemente da função estrutural. Eisenman reconhece que não poderiam simplesmente ser pilares cortados no topo: "Isso daria à coluna um significado adicional, chamando obviamente a atenção para si mesma como uma coluna sem suporte, enquanto deveria ser apenas uma marca ou um elemento primitivo em um esquema formal.” (EISENMAN et al., 1975, p. 16, tradução nossa) A forma não pode ter um significado definido, seja positivo, seja negativo, pois é importante gerar ambiguidade, incerteza para não fixar a leitura na estrutura aparente, permitindo, assim, acesso à estrutura profunda. É importante que o objeto não seja ambíguo em sua leitura como forma, mas, sim, na leitura de suas relaçôes. Em seu texto sobre a House II, exemplifica esta situação também utilizando pilar como exemplo, este não deve gerar dúvida quanto à sua forma, seja quadrada, seja redonda, etc., mas, sim, quanto às suas relações, se é estrutural, se não porta carga, etc. ${ }^{4}$

A primeira malha que encontramos tem origem ambígua, pode tanto ser exercício intradisciplinar de Eisenman, a aplicação do diagrama nine-square sobre o quadrado da planta, da divisão tripartida que apreende em Terragni, ou necessidade formal a partir da noção de fechamento que defende em

3 Leitura plausível e possível, visto que a recursividade é uma característica importante do trabalho de Eisenman. Operações são repetidas sobre o resultado de operações, deste modo, elementos podem se compor e decompor pelos mesmos princípios. Da mesma forma que quatro pilares ensejam um volume, um pilar pode ensejar quatro planos.

4 Descreve através de situação em que sobrepõe dois sistemas estruturais distintos, ambos capazes de suportar o edifício. São possíveis, então, quatro leituras: ambos os sistemas portantes, as duas variações de um ou outro com função estrutural e, ao deslizar a função estrutural de um para o outro, a leitura não permite fixar a função portante em nenhum dos dois sistemas, nenhum é então lido como estrutural. Esta última opção entende como meio de apreender estrutura profunda (EISENMAN et al., 1975). 

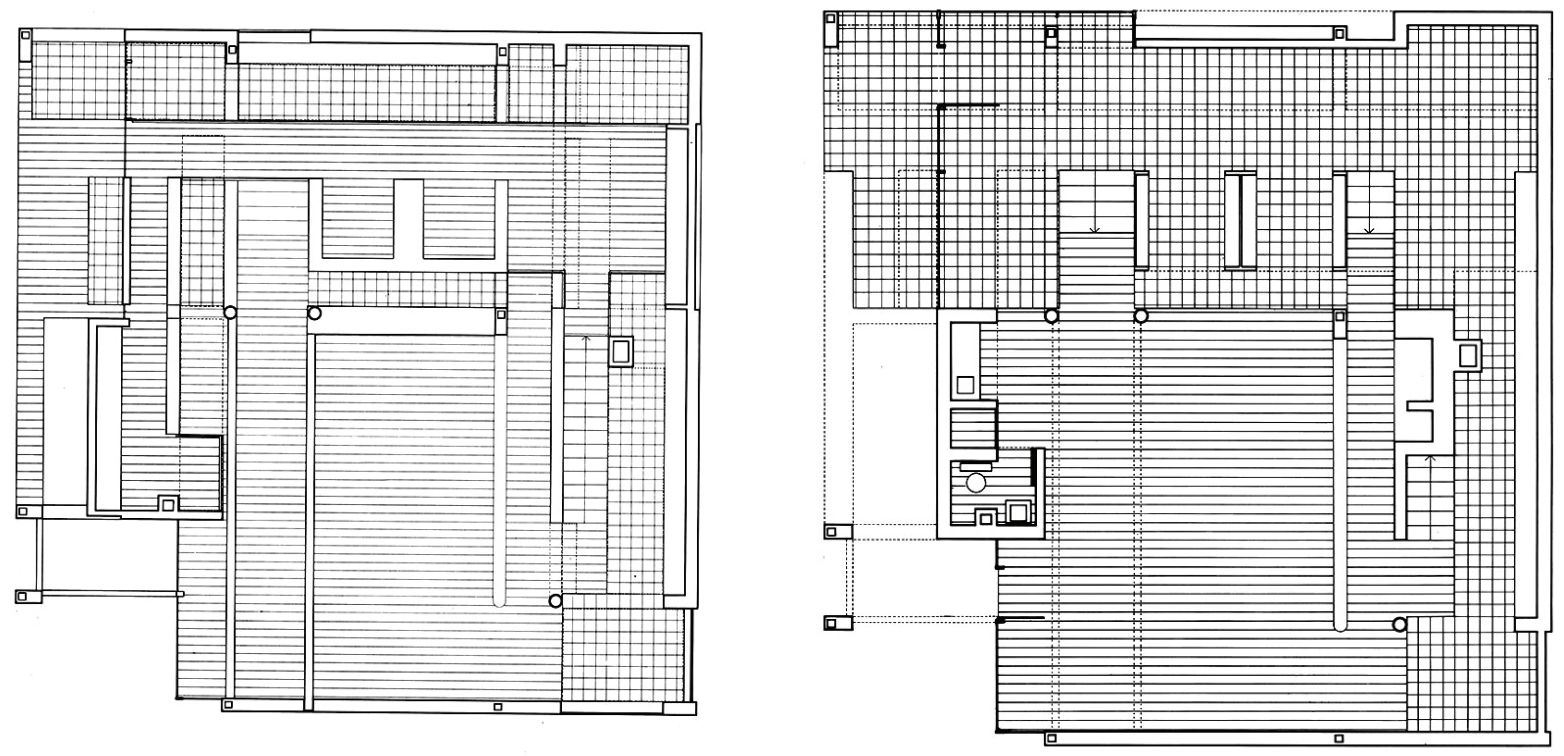

Figura 60: Plantas da House I do terreo e do primeiro pavimento. Fonte: EISENMAN, Peter et al. (1975, p. 19-20).
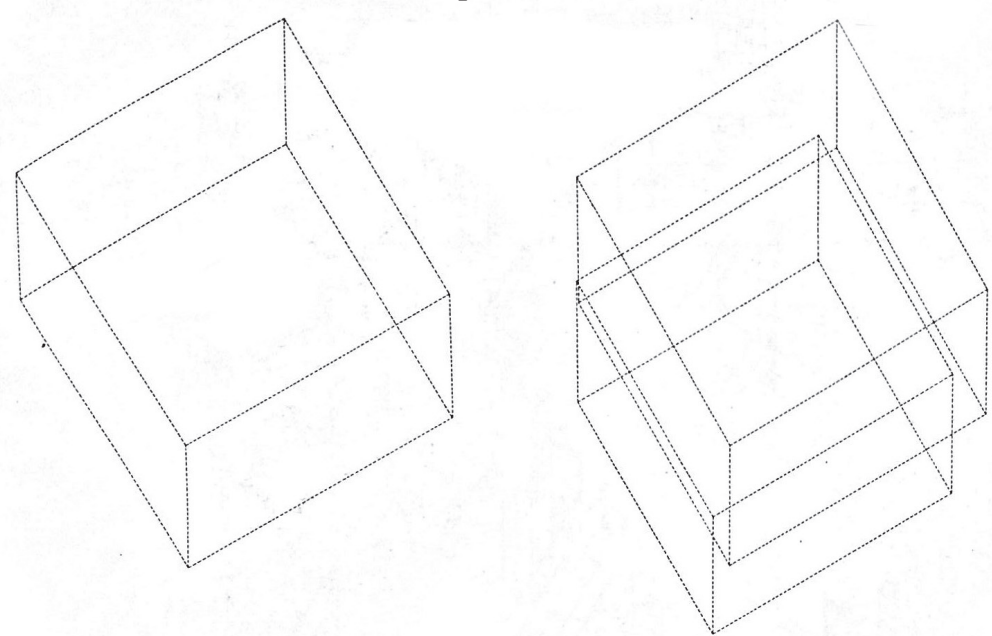

Figura 61 - Deslocamento no plano horizontal do cubo formando diagonal Fonte: EISENMAN et al (1975, p.22).

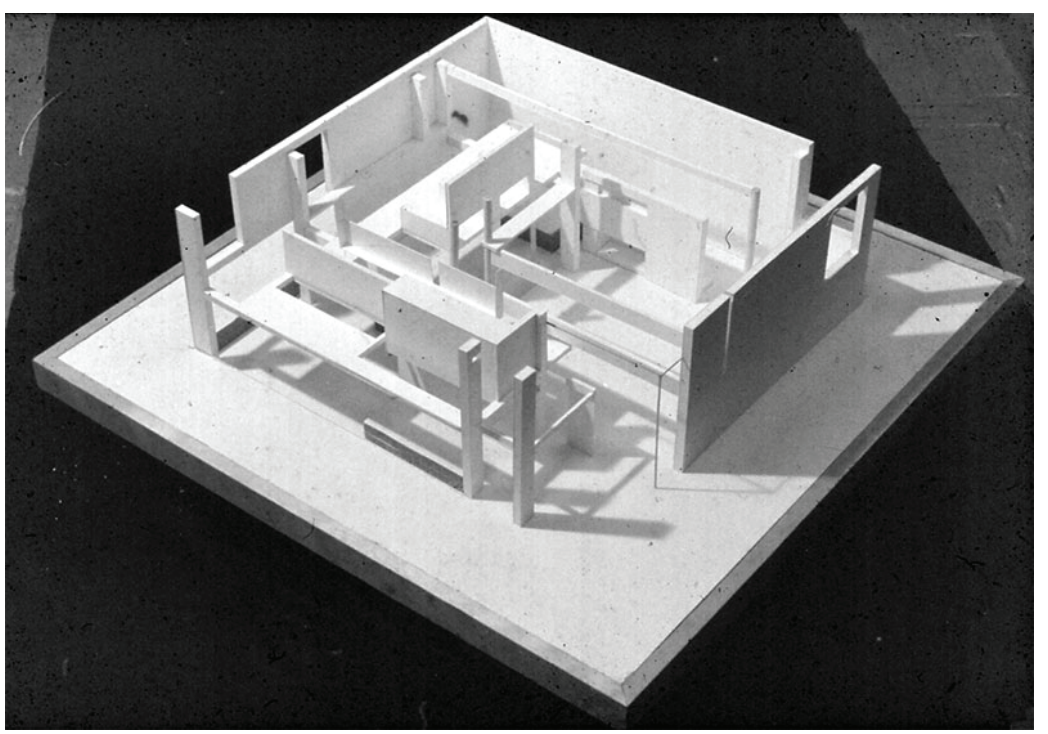

Figura 62 - Maquete House I, relação massa-superfície Fonte: Site Eisenman Architects. 


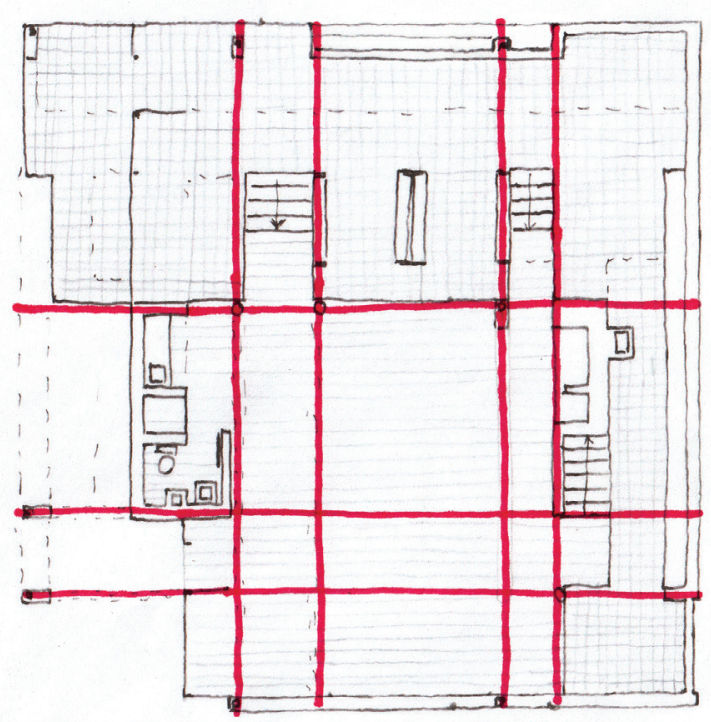

Figura 63 - Desenho dos planos a Figura 64 - Planos com espessura. partir das colunas. Fonte: Elaborada Fonte: Elaborada pelo autor. pelo autor.

suas análises presentes na Tese. Neste sentido, os dois quadrados deslocados pela diagonal sugerem um quadrado maior dividido em três, por três. Como vimos em seu texto Notes on Conceptual Architecture, Eisenman discute a necessidade de respeitar as regras da materialidade, visto que, por exemplo, os planos têm espessura. ${ }^{5}$ Com isso, vemos que as divisóes do quadrado em nove formam volumes, e cada um dos planos destes volumes sofre a mesma operação recursiva, formando o volume dos pilares e vigas.

Essa malha de planos ortogonais apresenta a condição importante ao arquiteto neste momento, a frontalidade. A malha ortogonal possui um sentido prioritário de leitura, uma linearidade aparente no acesso único ao edifício. Apesar de esta frontalidade aparecer em diferentes leituras que faz na Tese, como no Pavilhão Suiço de Le Corbusier, a referência aqui é a frontalidade que lê na Casa del Fascio $0^{6}$ o "baralho de cartas". Como no projeto de Terragni, a fachada de acesso e a oposta são planos, já as laterais mostram a sequência de planos. Identificando os planos a partir da descrição de Eisenman dos pilares, apreendemos essa prioridade. Em um sentido, encontramos quatro planos claramente definidos, no outro sentido, apenas três.

Há outras formas de notação que sugerem outros planos. Característica marcante do trabalho do arquiteto, as dualidades permeiam todos os níveis, formam um labirinto de ferramentas que

5 É uma constante no pensamento de Eisenman a recusa a uma abstração total do diagrama, como vimos acima, sua crítica a Sol LeWitt por este aspecto (EISENMAN, 2004b). Posteriormente, reitera este ponto como crítica no livro Diagram Diaries: "[...] os diagramas tornam-se abstrações geométricas redutivas, ignorando coisas como a espessura necessária de paredes e seus possíveis efeitos como notações no espaço." (EISENMAN, 1999, p. 52 , tradução nossa).

6 Em sua Tese, Eisenman credita a frontalidade de Terragni como consequência dos planos de referência e da influência do cubismo (EISENMAN, 2006c, p. 235). 


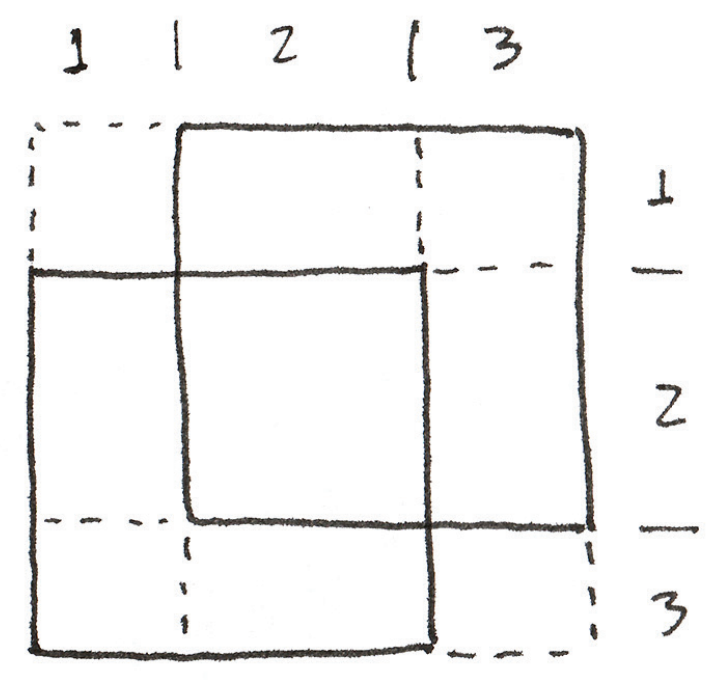

Figura 65 - Deslocamento dos dois quadrados formando divisão tripartida. Fonte: Elaborada pelo autor.

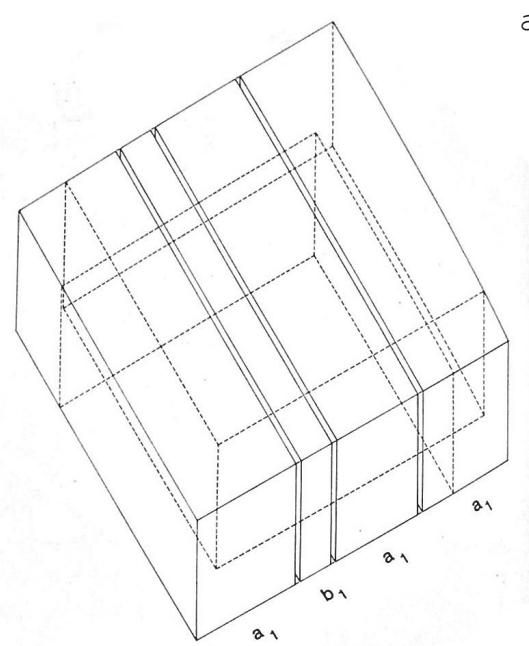

Figura 67 - Duas sequencias - A1-B1-A1-A1 e A2-B1-A1-B2-A2

Fonte: EISENMAN et al (1975, p.22).

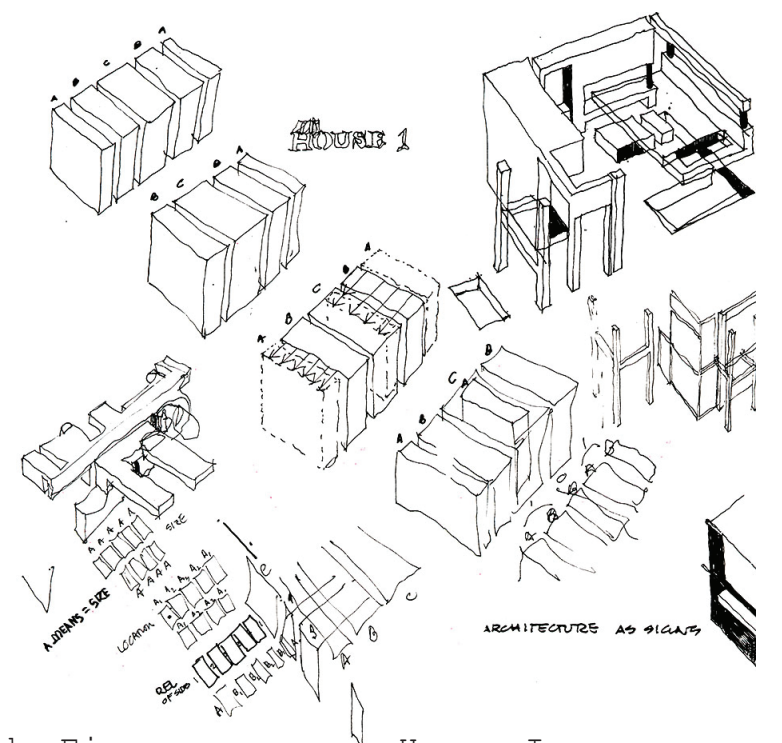

Figura 68 - Croquis de Eisenman para a House I que sugerem as sequencias de volumes não flexionadas. Fonte: Site Eisenman Architects.

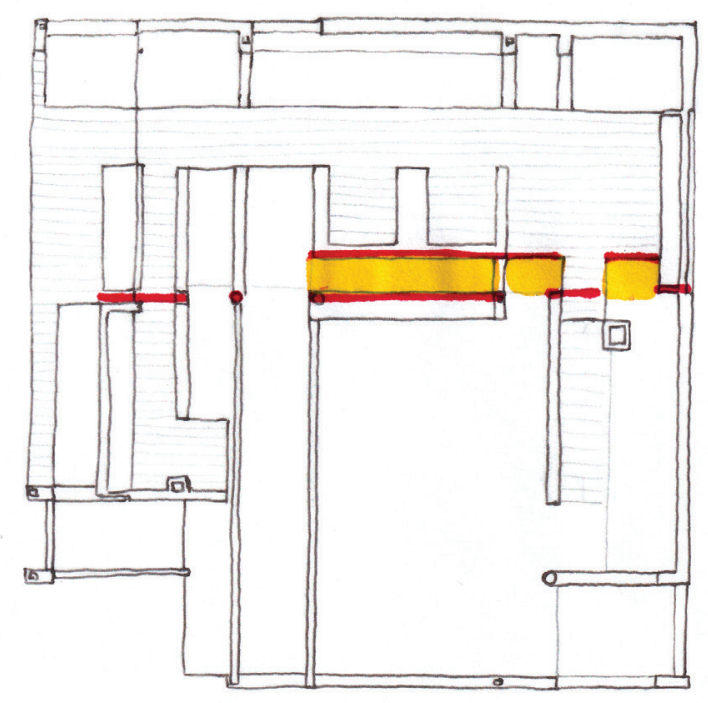

Figura 66 - Plano inferido de outras referencias; obstaculos e volumes negativos. Fonte: Elaborada pelo autor.

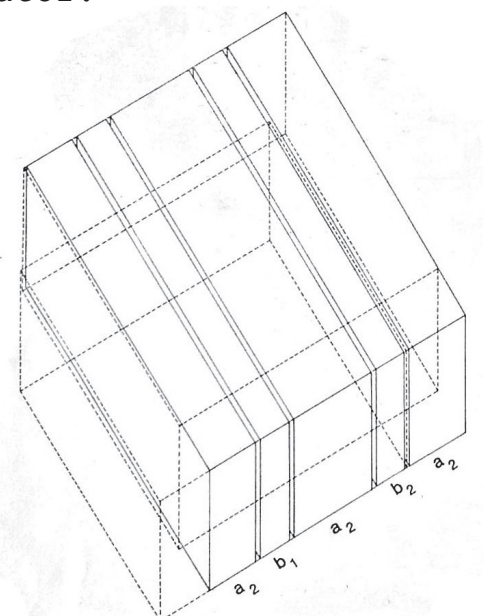


Eisenman mobiliza. A ideia de um real e um virtual que embasa a dualidade de estruturas, profunda e aparente, opera também nas notaçôes na estrutura aparente. Além dos planos formados pelas vigas e pilares, há outros planos formados por vazios. Outrossim, Eisenman destitui o valor de janelas, e as aberturas tornam-se recortes, ausência, volumes negativos - diferentes aberturas na fachada, por exemplo, são planos ou volumes subtraídos. O plano que náo pôde ser inferido pelos pilares no sentido ortogonal, para fechar os volumes da divisão em nove, é implicado comprimido entre o volume de serviços no térreo e o volume negativo no primeiro pavimento, por espaços negativos no patamar do primeiro pavimento, bem como entre o volume do primeiro pavimento e uma viga horizontal.

A frontalidade é marcada por Eisenman quando descreve que o sistema de planos divide o cubo por sequências organizadas a partir do plano frontal. Cita duas sequências: A2-B1-A1-B2-A2; e a outra A1-B1-A1-A1, sendo o B1-A1 coincidente (EISENMAN et al., 1975, p. 17). A associação de letras e números dá referência à similaridade entre as operaçóes - as operaçóes "A" e "B" correspondem ao acima visto da divisão do quadrado inicial em nove; "A" representam os resíduos do cubo, volumes, e "B" representa aquilo que compóe a espessura dos planos da divisão tripartida, um deslocamento.

Esta sequência ocorre no sentido longitudinal, é uma forma linear comprimida em uma forma centroide; a sequência seria A-B-A-B-A. Os diferentes números indicam a progressão da compressão: 1 é não flexionado, 2 é comprimido. A sequência sem um dos "Bs" mostra uma sobreposição fruto da compressão. Tal como nas análises que Eisenman faz de Le Corbusier, sobre sequências que induzem os próximos elementos, podemos extrapolar a partir das duas sequências de planos que apresenta uma sequência não deformada: A1-B1-A1-B1-A1. Esta sequência seria a forma linear, cuja dimensão extrapola o cubo. É possível prosseguir a operação e encontrar também etapa mais comprimida: A2-B2-A2-B2-A2. Há notações que fazem essas sequências no projeto.

A partir desta sequência de planos e dos volumes da lareira e de serviço, podemos compreender como essa compressão afeta a forma deslocando eixos da divisão em nove. Em relação a eixo de simetria em torno do vazio central, encontramos sequência de volumes comprimidos no sentido longitudinal do acesso à parede oposta. Os elementos da sequência A1 e A2 mostram a compressão. $\mathrm{O}$ plano inicial e o central são A1, enquanto o final é A2. O volume da lareira sob a escada corresponde ao volume de serviços em relação ao eixo de simetria, mas comprimido; a lareira seria um A3, ensejando passos adiante na sequência de transformaçôes de compressão. A compressão marca a

7 Sobre o uso de notações alfanuméricas nas operações de Eisenman, ver Izar (2015, p. 187-191). 


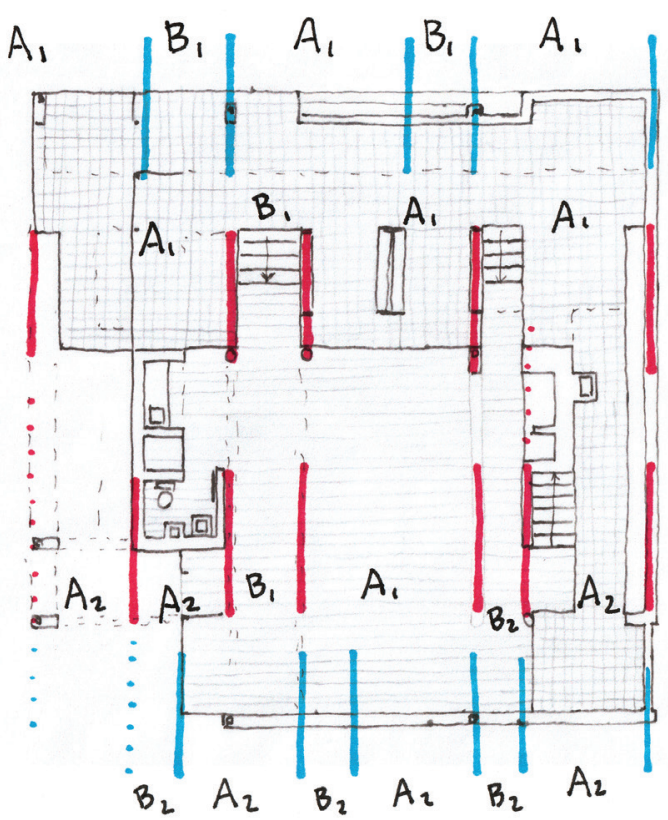

Figura 69 - Extrapolação sequência mais e menos comprimidas. Fonte: Elaborada pelo autor.

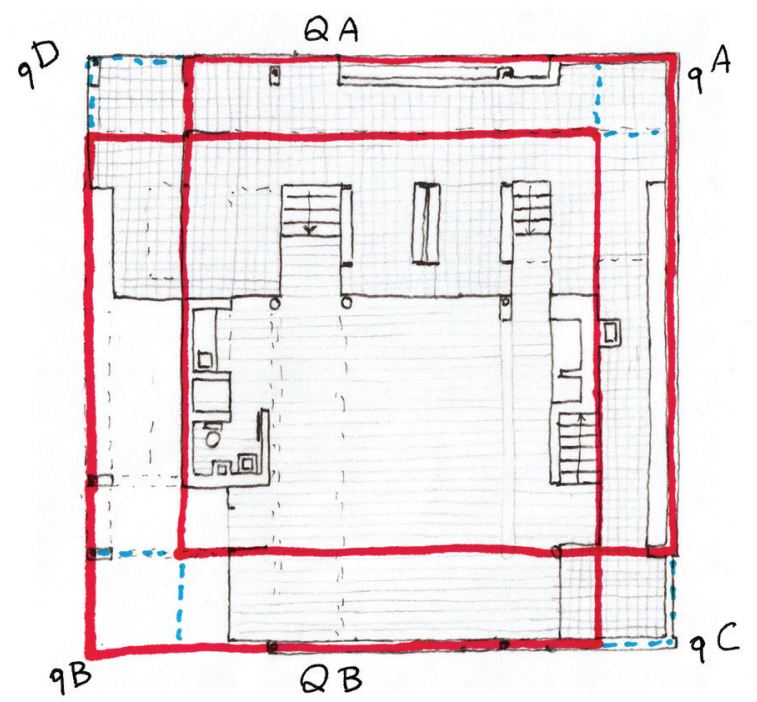

Figura 71 - Dois quadrados deslocados e suas projeções. Fonte: Elaborada pelo autor.

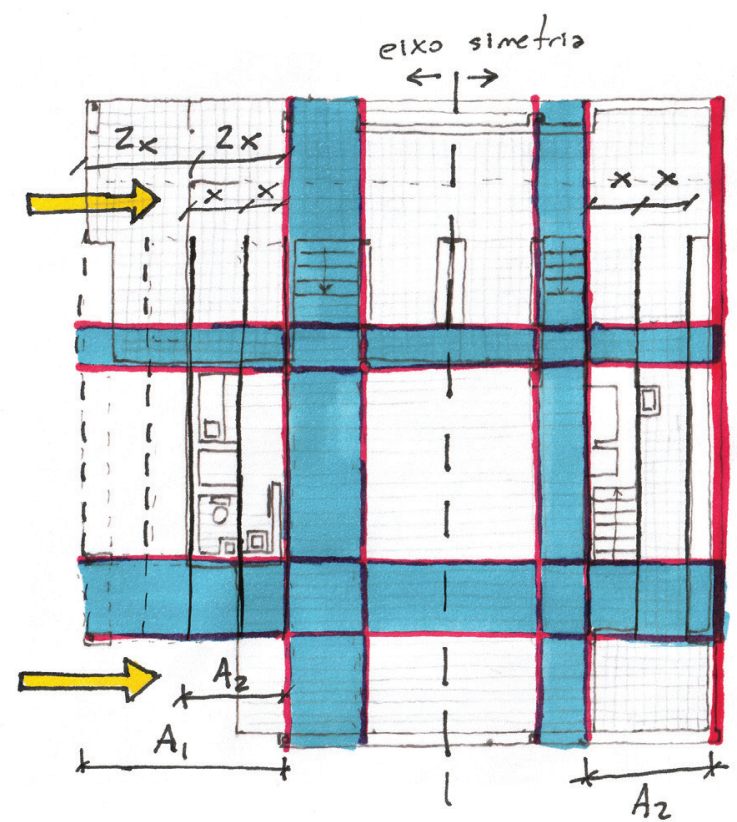

Figura 70 - Planos de compressão a partir da lareira. Fonte: Elaborada pelo autor.

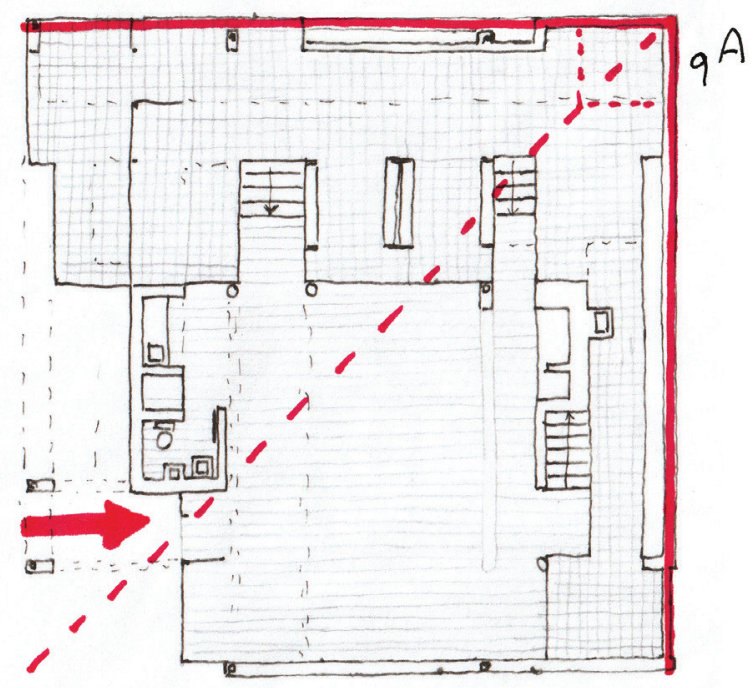

Figura 72 - Planos de referência em relação a diagonal. Fonte: Elaborada pelo autor. 
fachada anterior como plano de referência no sentido longitudinal, uma vez que este plano não é flexionado.

É possível um comparativo entre Eisenman e Wright sobre o sentido da arquitetura. Diferente da Martin House, na qual a lareira está no centro dos volumes, deslocada pela força de vetores, a lareira na House I está sob a escada, em volume comprimido, não partilha um volume próprio. Indicia a busca de Eisenman por aquilo que está no centro da arquitetura, sua interioridade - Wright utiliza a lareira, o fogo, como centro da casa, a ideia de abrigo, uma função simbólica. Por outro lado, ao formar um centro vazio, Eisenman contrapôe a condição dada por Wright da lareira como núcleo articulador; o volume vazio no centro marca a interioridade como vazio: "Quando essas totalidades eram ausências em oposição a presenças, elas sinalizariam uma condição potencial de ausência original na interioridade.” (EISENMAN, 1999, p. 62, tradução nossa).

A partir da ideia de sobreposição, apreendemos a dualidade que ocorre neste sistema de sequências: "Quando elas são sobrepostas, a estrutura subjacente é vista como comprimida, mas quando são separadas na mente, revela-se uma estrutura simétrica simples.” (EISENMAN et al., 1975, p.17, tradução nossa). Estrutura simétrica é o volume linear não comprimido. A simultaneidade de diferentes etapas da sequência, assim como a apreensão e manipulação destas duas estruturas notacionais pela separação delas na mente do observador, gera a ambiguidade que o faz perceber a estrutura profunda subjacente à forma.

Além deste sistema de planos, encontramos, a partir do mesmo deslocamento diagonal entre dois quadrados, um sistema de volumes. O deslocamento ocorre nos dois eixos horizontais formando um quadrado maior dividido em nove partes, como vimos acima; essa nova figura é um novo quadrado, mantendo a forma total como forma centroide. Denominaremos estes dois quadrados, cujo deslocamento forma a diagonal, QA e QB. A partir da noção de real e virtual, do movimento, os veremos com caráter opostos, um opera como cheio, massa, e o outro como vazio, ausência; essa condição também aparece nos quadrados menores dos cantos, que denominaremos qA, qB, qC e qD. O quadrado pequeno integralmente no quadrado "cheio", qA, forma o canto mais denso, de tal modo rígido que o encontro de planos de sua quina são os planos de referência vertical da grelha ortogonal. Pelo sistema de planos, encontramos um dos planos de referência, o do fundo, que serve de referência à compressão; o outro é obtido no sistema de volumes pela simetria da diagonal.

O quadrado pequeno qA apresenta estes planos de referência nas fachadas ao formar dois planos opacos sem interferências. Esta quina possui leitura forte, como massa, um volume vertical não flexionado por toda extensão. O quadrado integralmente no quadrado "vazio", qB, forma o canto 

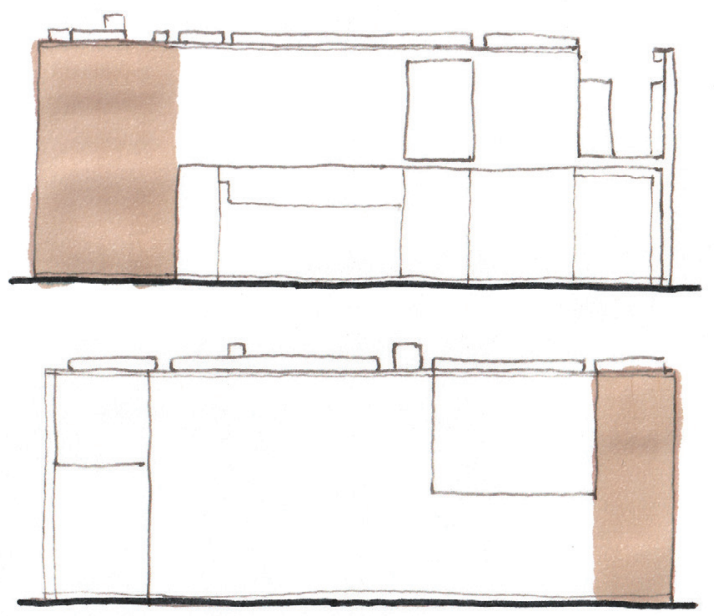

Figura 73 - Volume quadrado qA nas fachadas Norte e Oeste. Fonte: Elaborada pelo autor.

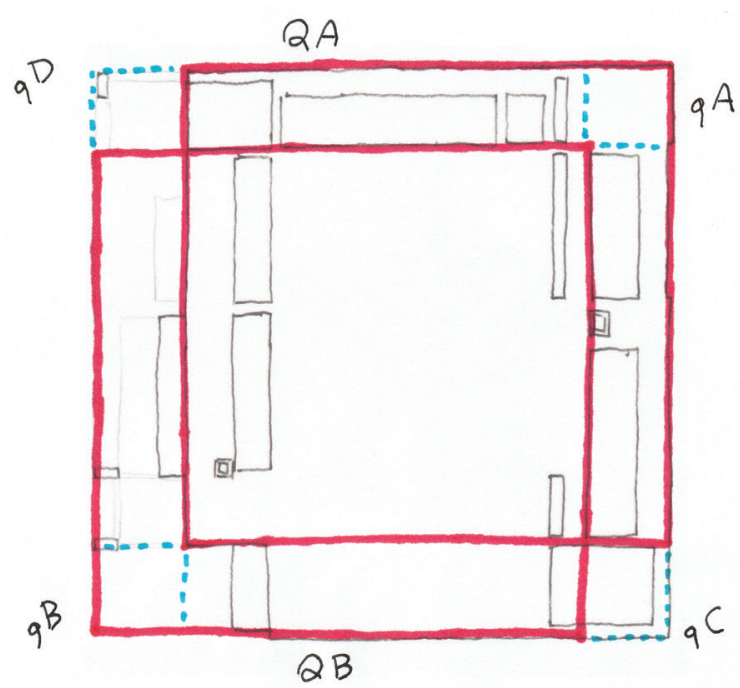

Figura 74 - Quadrados dos cantos vistos pela cobertura. Fonte: Elaborada pelo autor.

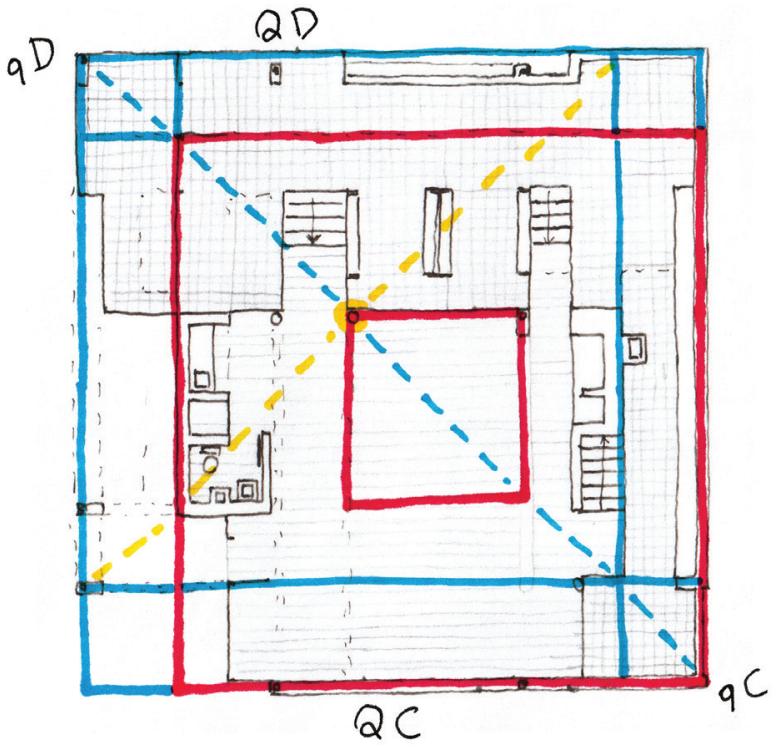

Figura 75 - Quadrados com vazio central e diagonal fraca. Fonte: Elaborada pelo autor.

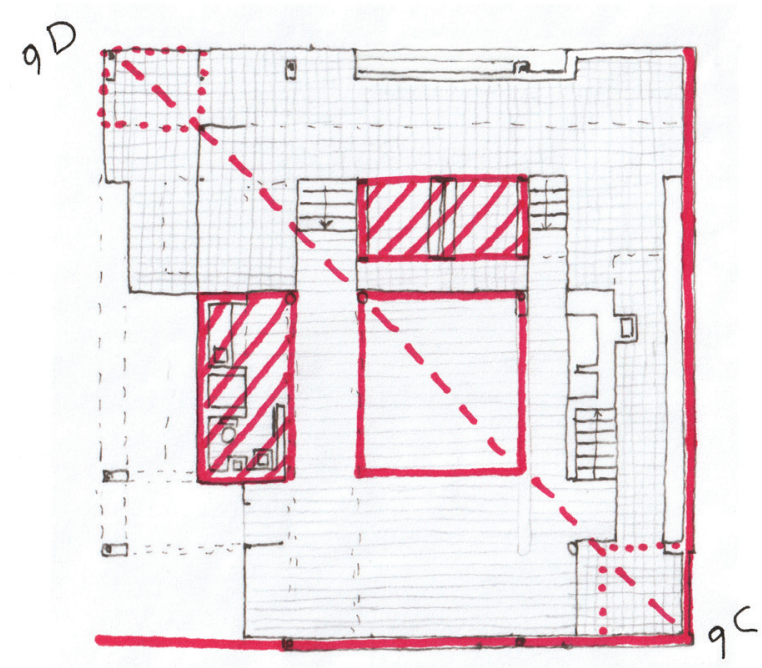

Figura 76 - Diagonal alternativa e volumes simétricos. Fonte: Elaborada pelo autor. 
mais diáfano, quase uma transição do vazio externo ao cheio interno, volume que não apresenta nada edificado, virtual. Os outros dois quadrados opostos, qC e qD, situados na diagonal fraca, são intermediários. A planta de cobertura revela esta condição pelas aberturas.

A intersecção dos dois quadrados forma também um quadrado central e, se retirarmos esses quatro quadrados menores, qA, qB, qC e qD, teríamos uma planta cruciforme. Eisenman adota um volume central vazio como na Casa del Fascio, mas, diferente desta, este espaço na House I não tem abertura na cobertura e não tem função. Neste caso, semelhante ao Asilo Infantile de Terragni e o Tallinn Museum de Aalto é a organização em torno de pátio que não tem motivo funcional, apenas formal; ausência, vazio semântico e funcional. Este pátio é o espaço central da divisão em nove.

Este vazio está centralizado em um quadrado como os dois inicialmente deslocados, mas na diagonal oposta, quadrado QC; já no quadrado deslocado na diagonal deste, QD, há pilar centralizado. Há uma constante inversão das referências, mas, independente desta segunda leitura, da diagonal fraca operar flexôes na forma, a diagonal descrita pelo arquiteto é a da leitura anterior. Confirmamos isso a partir do que vimos acima da sequência descrita pelo arquiteto junto aos desenhos e poderemos reiterar adiante conforme prosseguimos sobre a leitura das formas. Essa inversão apresenta um segundo sistema diagonal sobreposto ao primeiro. Além do quadrado central vazio cortado por essa diagonal, há dois volumes, um deles o de serviço, simétricos a ela. Esta inversão também inverteria o plano de referência lateral.

Sobrepondo estas duas diagonais, particularmente os dois "Ls" de planos de referência, gerase forma $U$ aberta no sentido da compressão. Diferente do sistema de planos, de caráter linear, o sistema de volumes é centroide, como vimos, forma planta cruciforme, marcada com mais clareza no primeiro pavimento. Pela leitura desta planta cruciforme, de seu deslocamento em direção à fachada do fundo, vemos marca da compressão analisada no sistema de planos também no sistema de volumes. Esse deslocamento também permite que vejamos os dois volumes rebatidos pela diagonal principal, o do fundo e o da lareira, este menor por estar comprimido.

Como vimos em sua Tese, Eisenman propóe que a dialética massa-superfície ocorre quando há conflito entre requisitos internos e externos, um de forma genérica centroide e outro linear. Agora, condizente a sua arquitetura conceitual, não há conflito entre demandas externas e internas, mas há conflito entre diferentes sistemas: um sistema de planos linear e um sistema de volumes centroide, ou, nos termos da arquitetura conceitual, um sistema aditivo e outro subtrativo. Como compreende em Terragni, intersecciona os dois sistemas para obter a ambiguidade desejada. Além disso, o sistema linear é comprimido para adequar-se à forma centroide, e esta é afetada pelo vetor do sistema linear. 


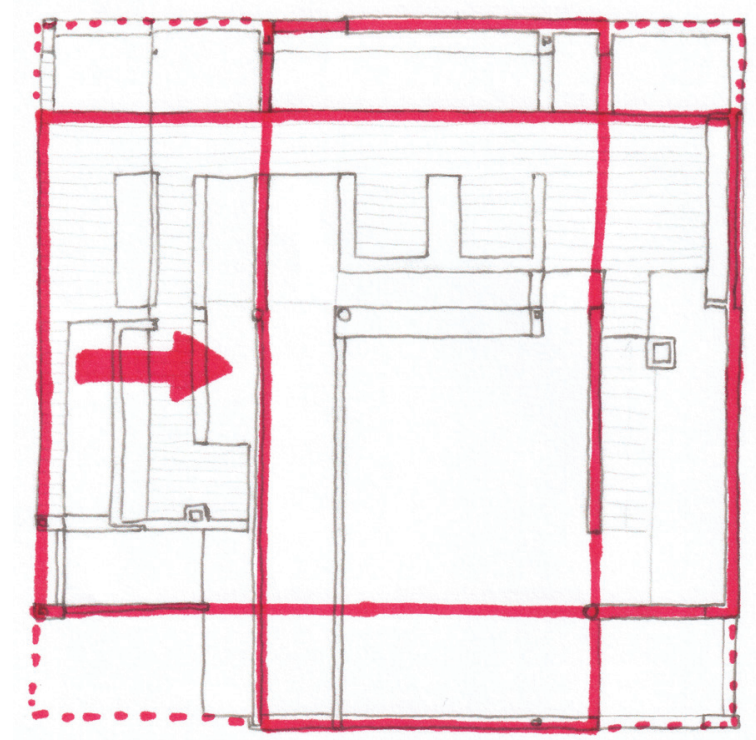

Figura 77 - Forma cruciforme no primeiro pavimento e vetor de compressão. Fonte: Elaborada pelo autor.
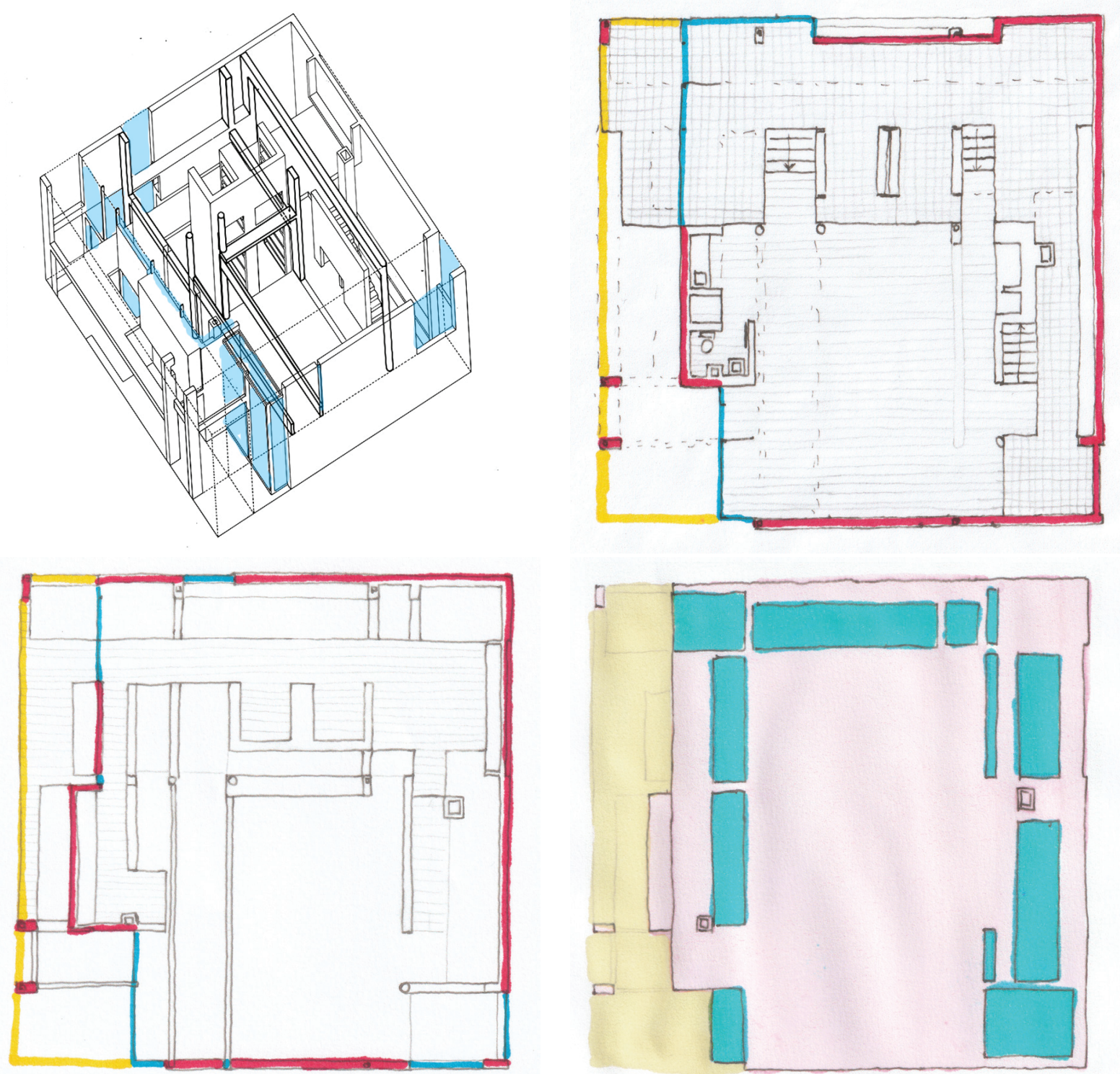

Figura 78 - Aberturas e marcações das superfícies. Fonte: Elaborada pelo autor. 
A leitura externa mostra a dialética massa-superfície - como massa, a casa apresenta-se como cubo corroído por volumes e aberturas; como planos, são a sequência de planos, o "baralho de cartas".

Principal corrosão do volume ocorre pela força de compressão já vista, que é também o empuxo do deslocamento diagonal. Considerando o cubo que delimita a forma total da casa, é apenas na face comprimida pelo acesso que não há plano marcado por extensões de vedação, sendo esta face caracterizada como volume negativo. A superfície opaca recua emergindo panos de vidro e expondo pilares e vigas. É o único lado da casa com grandes extensões de vidro. Retomando a forma "U”, vista no sistema de volumes, esta fachada é a face aberta desta forma, é o fechamento do quadrado que recua. Esse plano empurrado permite leitura análoga à que Eisenman propóe ao Pavilháo Suíço de Le Corbusier, como se o volume fosse composto de diversas superfícies, a envoltória opaca, ao recuar, revela outro volume de caráter distinto. Tal como a progressão de Le Corbusier ao diáfano, na House I, a progressáo ocorre do externo denso, opaco, à pele de vidro, diáfana, e chega ao centro vazio. Condizente com a proposta formalista de Eisenman, a forma autorreferente, ao despir as formas, não resta nada, reforça a noção do centro vazio.

Essa leitura de superfícies é reforçada por ambiguidade da leitura externa como massa devido a detalhes nas fachadas junto ao solo e à cobertura. Há frisos que permitem a leitura das superfícies opacas como pele envolvendo volume. As aberturas nas demais fachadas e na cobertura têm dupla leitura: são tanto superfícies de massas internas, volumes (como essa pele exposta no acesso) quanto sugerem planos interseccionando as fachadas. Aberturas menores, como fitas, sugerem cortes de planos, a leitura da casa como superfície. As vigas e pilares que afloram junto ao acesso, não empurradas por este, marcam um plano de forma oposta, de modo positivo. Este volume é marcado de forma análoga a que Eisenman lê na Coonley House de Wright. Tal qual a sala de jantar do projeto de Wright é composta por pilares puxados de uma superfície, estes pilares de Eisenman são puxados da fachada anterior, o plano de referência.

Estes dois pilares desnudos no acesso também indicam a predominância do eixo longitudinal, o que corrobora a leitura da sequência de planos linear, do eixo do acesso que estrutura a sequência de planos ortogonais. Este plano não comprimido é o próprio vetor longitudinal de compressão. Sua posição também anuncia a diagonal, uma vez que estende a forma a partir de sua posição excêntrica. Por estar deslocado, o eixo longitudinal é equilibrado em relação ao eixo central dos quadrados QB e QC - eixo central marcado por divisão no volume de serviços e no volume da lareira. O eixo longitudinal deslocado é equilibrado pelo volume do primeiro pavimento e pelo rebaixo do térreo; este equilíbrio é reforçado no térreo por abertura na parte rebaixada, em oposição ao acesso. Esta 


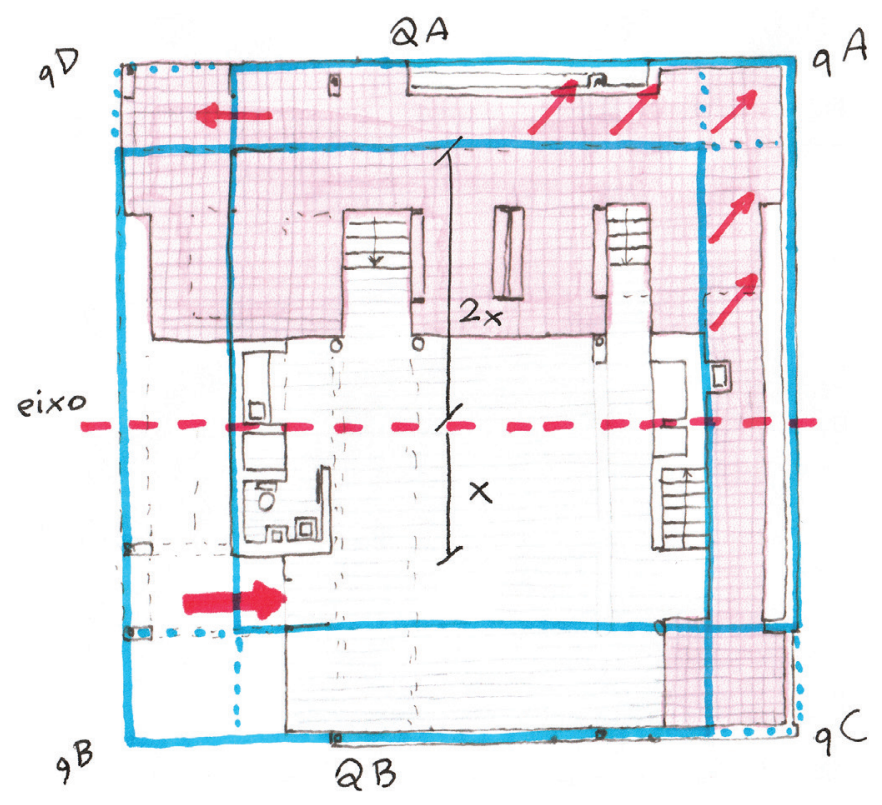

Figura 79 - Equilíbrio do acesso em torno do eixo deslocado e extensão da forma. Fonte: Elaborada pelo autor.
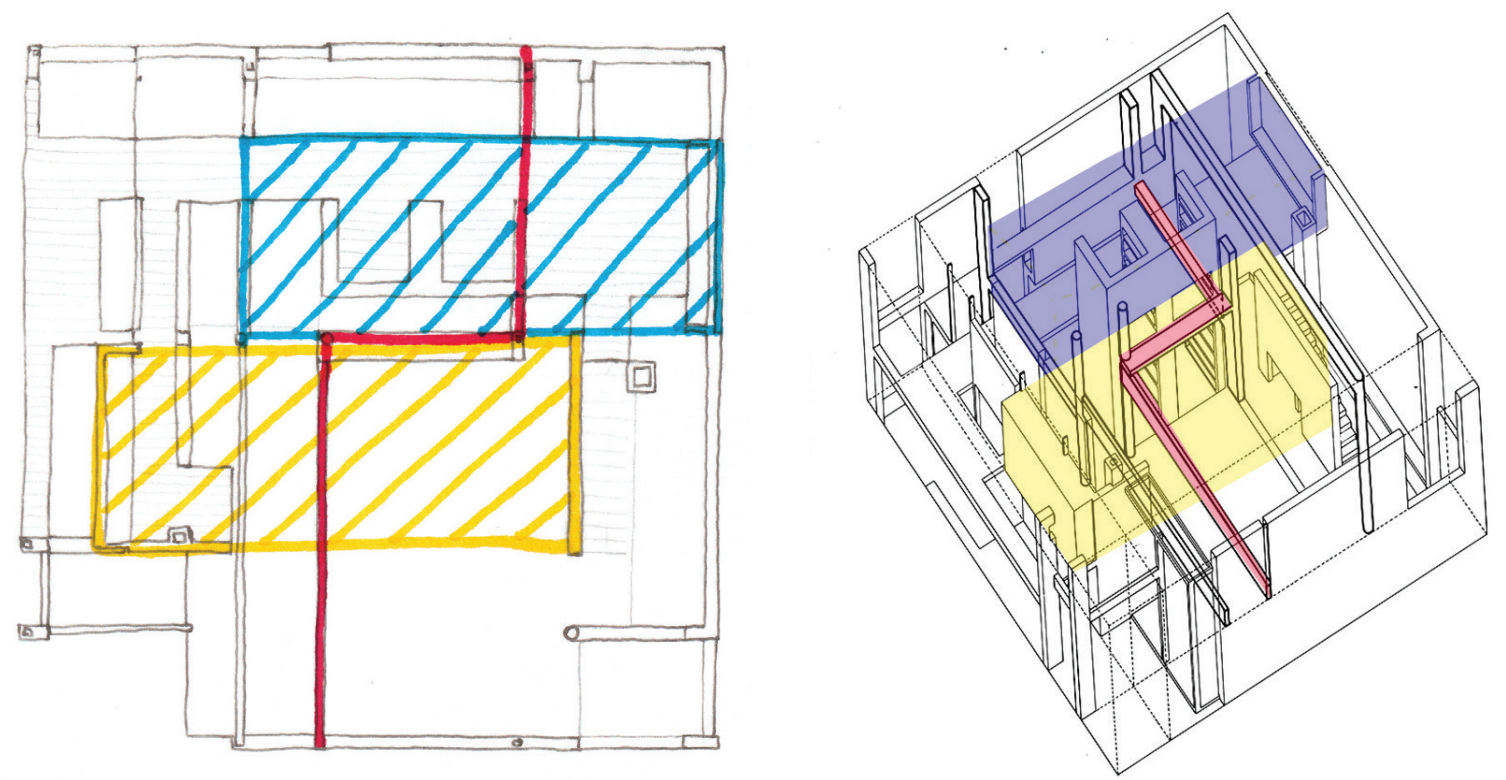

Figura 80 - Diagonal pela supressão de vigas e volumes deslocados. Fonte: Elaborado pelo autor. 
abertura, por ter menor força, possui maior braço em relação ao eixo dos quadrados QB e QC, forma de equilíbrio análoga à que Eisenman encontra na Martin House de Wright.

$\mathrm{Na}$ observação interna ao volume, a diagonal aparece de modo muito sutil. É formada por ruído na malha ortogonal perceptível ao adentrar a casa. A diagonal afeta tanto o sistema de volumes quanto o de superfícies, em certo sentido, ela ocorre na sobreposição destes dois sistemas. Quanto ao sistema de volumes, a diagonal faz com que dois volumes do primeiro pavimento escorreguem entre si.

Retomando o quadrado QD, essa diagonal surge a partir da distorção de eixos longitudinais deste quadrado. O deslocamento do volume próximo à fachada lateral arrasta parte do eixo; a distância do deslocamento é a medida que falta para o quadrado QD atingir a fachada anterior. Estes eixos de QD formam cruz que aparece marcada nas fachadas - particularmente nas duas fachadas que não sofrem deslocamento, a frontal e a lateral oposta ao volume deslocado, os eixos aparecem como pequenos rasgos de espessura mínima. Na lateral deslocada, o eixo empurrado aparece no local original junto à abertura maior, marcando divisão entre opaco e vazio; já no local deslocado, marca de forma oposta, de forma positiva, com um pilar. A parte ao fundo aparece marcada pela lateral do volume deslocado, cujo traço fica imprimido na parede.

A diagonal que Eisenman utiliza para movimentar a forma opera sobre a malha ortogonal, sobre o sistema de planos, cortando as superfícies. Este efeito aparece pela omissão de duas colunas opostas em dois planos consecutivos, as quais aparecem no piso e na fachada apenas como marcas. Eisenman descreve a diagonal na estrutura aparente por esta ausência de pilares e das partes das vigas que os conectariam, forma a diagonal a partir dos elementos restantes.

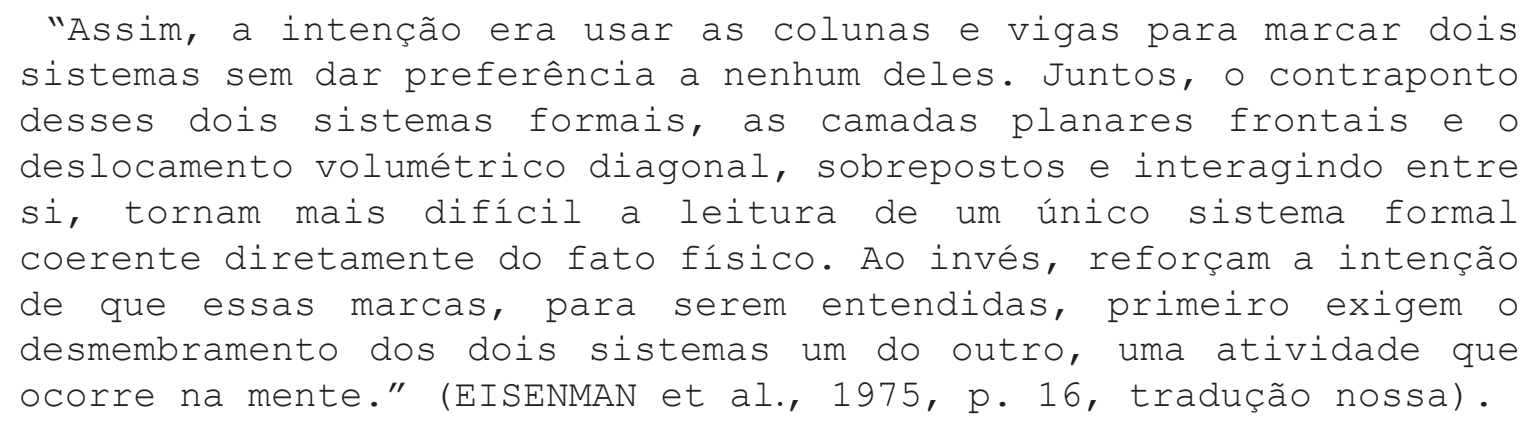

Condizente com a ideia de acúmulo de percepçôes ao longo do tempo, do olho que apreende em um percurso, a percepção dos diferentes sistemas e suas relaçóes, sua sintática, não ocorre de um ponto de vista, mas do acúmulo de experiências. Esse processo ocorre em duas etapas: primeiro a percepção do que se apresenta e, em seguida, o processo mental de síntese e de separação.

Além destas notaçóes, o pilar marcado no piso marca a lateral do quadrado deslocado 

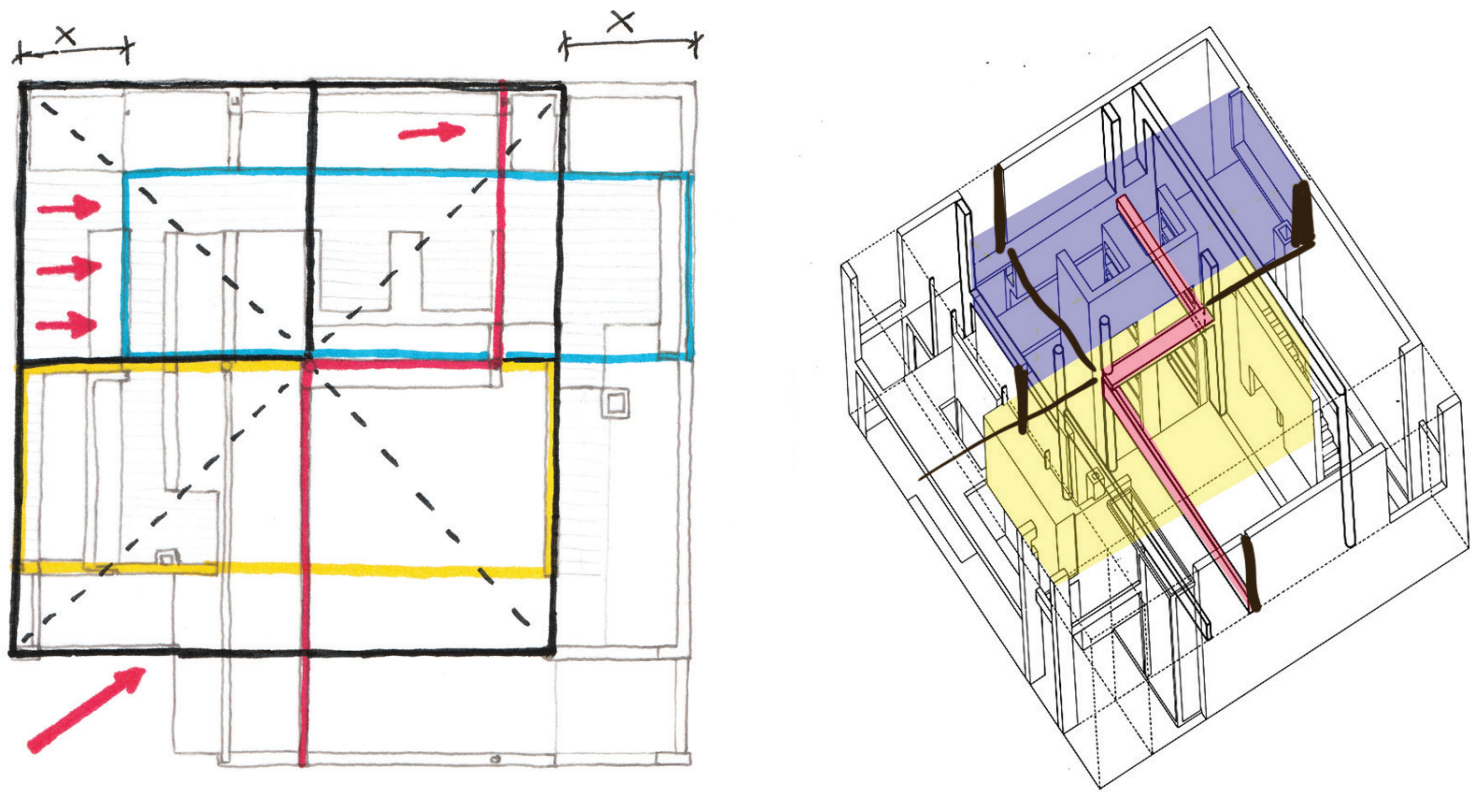

Figura 81 - Deslocamento diagonal com eixos marcados.

Fonte: Elaborada pelo autor.
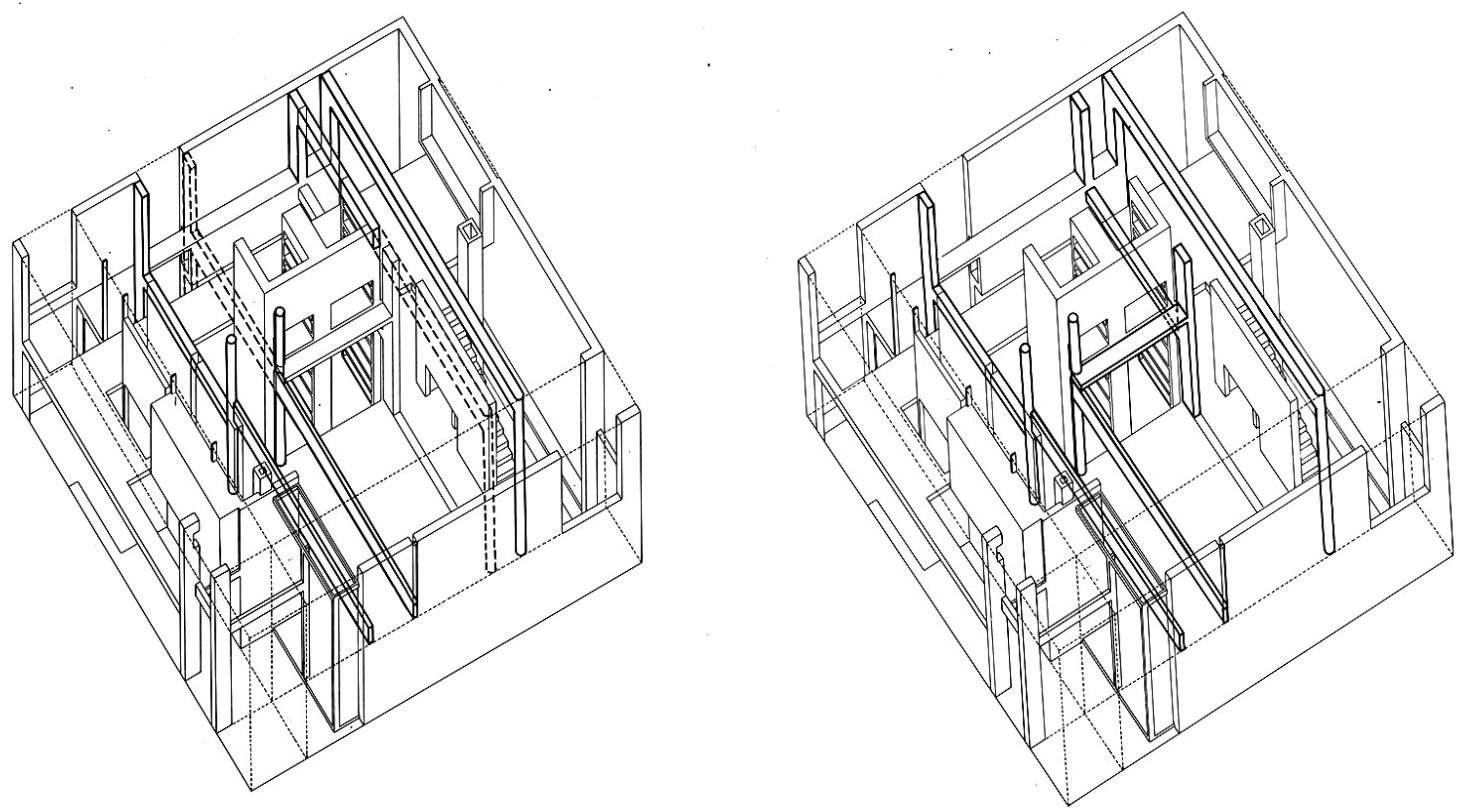

Figura 82 - Supressão de colunas e vigas marcando a diagonal.

Fonte: EISENMAN et al (1975, p. 22). 
inicialmente, QA, e ele em relação ao plano adjunto, cujo pilar está inserido na parede da fachada, enseja um vetor que o empurra da fachada para dentro da casa no sentido da diagonal, permitindo apreendê-la. A diagonal descrita por Eisenman reforça a leitura dos quadrados como cheio e vazio, $\mathrm{QA}$ e $\mathrm{QB}$, uma vez que ela opera neste sentido de deslocamento. A diagonal é formada por duas vigas ortogonais e uma longitudinal. Esta viga é horizontal e está centralizada no quadrado cheio, QA, enquanto uma das verticais é eixo do quadrado que opera como deslocamento, QB.

O interessante desta viga é o fato de ela ser horizontal por relaçóes que gera - entre duas vigas verticais, ela ser horizontal reforça a quebra formadora da diagonal. A viga não "dobra", ela é quebrada. A sequência do plano da viga horizontal em direção à fachada é um plano negativo, marcado por recortes. Isso reitera a leitura dos planos frontais, as vigas marcadas como tal, verticais, ocorrem apenas ortogonais ao eixo do acesso, reforçando a leitura como "baralho de cartas", não havendo trecho de viga vertical no sentido oposto. A forma horizontal da viga no sentido longitudinal, junto com saliências nas paredes externas, forma continuidade com o plano do piso do primeiro pavimento, marcando-a como parte de um plano horizontal e não como um plano longitudinal concorrente ao do acesso.

Este plano horizontal junto com o rebaixo do térreo formam divisão tripartida na vertical: o rebaixo do térreo é o limite inferior da forma, o térreo e o primeiro pavimento/plano da diagonal são as divisōes e a cobertura é o limite superior. O rebaixo do térreo não tem justificativa além da forma, não tem função, a topografia do lote não o demanda, visto que a casa está localizada em porção plana, cujo entorno sobe suavemente; assim, seu uso não necessita de diferença de nível e seu pé-direito comporta dois pavimentos. Sua não necessidade pela altura é reforçada pelo rebaixo não coincidir inteiramente com o primeiro pavimento.

O acesso e o vazio central definem o plano do térreo como referência horizontal; o friso junto ao solo na parte externa do edifício reforça esse plano. O rebaixo do térreo, além de equilibrar o acesso, pode ser visto como resultado do deslocamento horizontal da diagonal. Esta porção do piso é puxada formando o primeiro pavimento e revelando parte da estrutura enterrada. A viga marcada no piso térreo pode ser compreendida como forma virtual de apresentar estrutura que afunda no solo. Trata-se de referência à malha cartesiana que se prolonga independentemente de referências físicas como o solo. Em sentido oposto, a forma de "L" deste rebaixo indica o arraste do piso causado pelo quadrado QB. O primeiro pavimento opera como equilíbrio a este rebaixo; operação como a que Eisenman lê no Tallinn Museum de Aalto.

Com isto pudemos explorar, a partir do proposto por Eisenman, a House I, procurando, como 


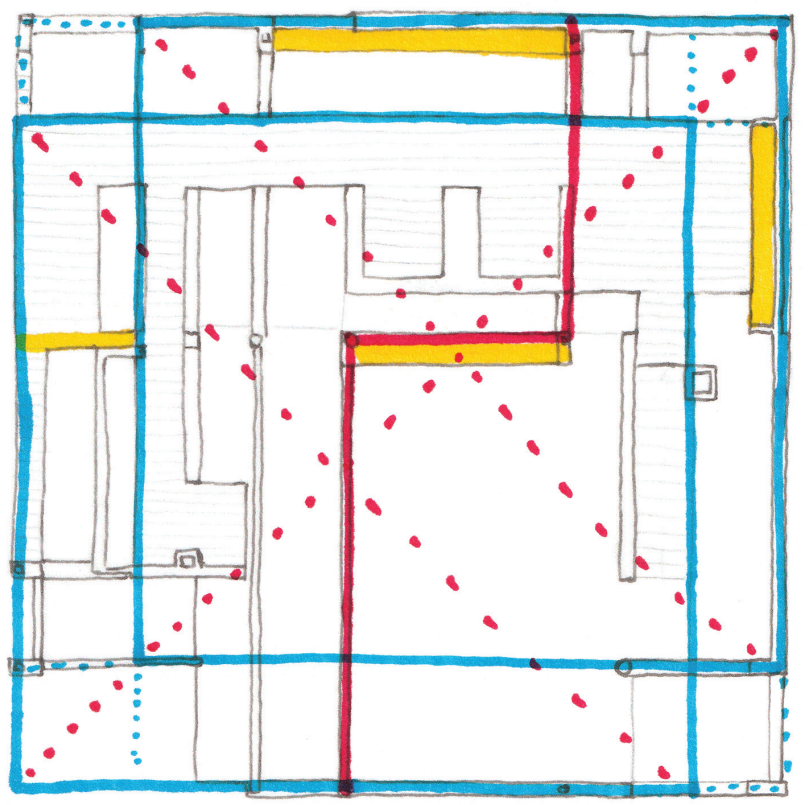

Figura 83 - Diagonal centralizada no quadrado forte e planos aos quais a viga horizontal se remete. Fonte: Elabotada pelo autor.
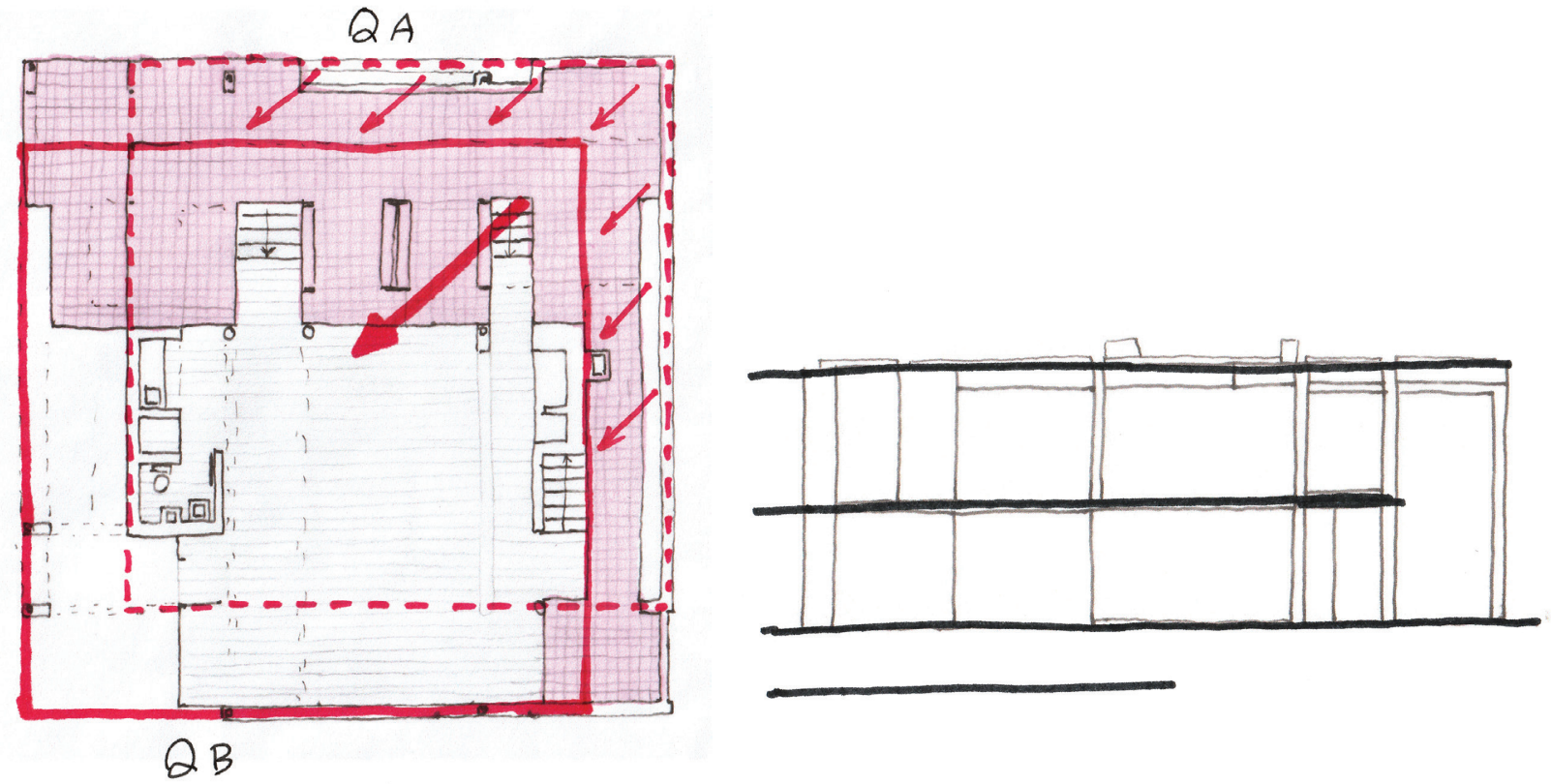

Figura 84 - Divisões horizontais e deslocamento do térreo.

Fonte: Elabotada pelo autor. 
um trabalho predominantemente de sintaxe, uma arquitetura autorreferente. Apesar dos aspectos de vocabulário utilizados por Eisenman serem próximos aos utilizados por Le Corbusier e Terragni, não há elementos rebuscados como a grelha, que aparece na iluminação zenital da Casa Del' Fascio ${ }^{8}$, são basicamente planos opacos, vidros e vazios. Sua intenção, em termos de vocabulário, é limpar de referências externas, é buscar o mais neutro; podemos extrapolar que, neste momento, seu vocabulário é mínimo em favor de uma sintaxe máxima. O próprio uso do branco Eisenman justifica para que tenha menos significado - o branco estaria mais próximo a um plano abstrato e, ao ser associado a estilo recente, o estilo internacional, teria menos chance de adotar novo sentido. A ambiguidade, ao ter um significado, um contexto de aplicação esperado, utilizado fora de norma, o usuário passa a não conseguir fixar o sentido do elemento.

As operaçôes são para desvincular os elementos de significados pré-definidos, evitando que adquiram novos; a intenção é que os elementos se tornem notaçôes no conjunto de relaçôes. Isso fica claro no processo visto acima de deslocar a leitura dos pilares, dificultar sua leitura como estrutura; consiste em um processo de minimizar carga semântica, elementos como pilares, planos, não podem ter um significado definido, é preferível que gere ambiguidade, incerteza (EISENMAN, 1999, p. 57-58). Tal qual pontos que analisa em sua Tese (EISENMAN, 2006c), como a dialética massasuperfície, ou o jogo entre sistemas volumétricos estáticos e dinâmicos, e a sobreposição na House I entre dois sistemas de notação, a ferramenta que expóe no From Object to Relationship II (EISENMAN, 1971) é a utilização da ambiguidade, da incerteza, o significado deslizante como ferramenta para postergar a fixação de um sentido, para minimizar a carga semântica, o culturalmente condicionado, de modo a levar o usuário a apreender relações entre as formas, o sintático.

As leituras que opera na Tese partem de consideraçóes constantes e claras tanto das demandas externas - local, acesso - quanto internas - intenção, programa. Esta proposta de leitura forma um conjunto de informaçóes, de axiomas a partir dos quais o projeto é desenvolvido por processo lógico de dedução. Na House I, vimos processo diferente: a autorreferência é expressa por relação circular, a forma é reflexo de uma estrutura profunda cuja apreensão vem da forma. A internalização do contexto e a minimização do programa, compreendidas como partes da dimensão semântica, retiram as fontes para pontos de partida estáveis. Não é possível formar um conjunto de axiomas, o ponto de partida da análise, a diagonal, estes foram dados fornecidos pelo arquiteto, que deslizaram de motivação para resultado. Como pudemos ver, diferentes sistemas, notaçóes, operaçôes partem uns

8 Elemento, por exemplo, que Eisenman incorporará progressivamente na sequência de casas, ao ponto de, na House $X$, haver um volume em cubo todo com este tratamento. 
dos outros e acabam se corroborando mutuamente. Há uma constante inversão de começos e fins, a diagonal, sistema de volumes, acaba por embasar a compressão do sistema de superfícies e vice-versa. A arquitetura como processo leva à autonomia pela autorreferência. Uma consequência importante do fato de o Eisenman conjugar a náo fixaçáo de sentido com objeto autônomo autorreferente é que isso também dificulta a fixação das relaçóes da forma.

Em certo sentido, a imiscuidade de Eisenman entre projeto e texto não é apenas uma opção ou um reflexo de sua atuação teórica, mas uma necessidade de referência, de estabilidade. A ambiguidade atinge as relaçôes de modo que poderíamos ler outra estrutura profunda, outra cadeia de relaçôes, as quais não teriam relação com a intenção de Eisenman. Podemos notar que as análises que descreve em sua Tese são processos dedutivos, a partir de premissas desbobra-se a conclusôes, do geral chegase ao específico. Sinal disto é que Eisenman faz todas as análises independentemente do que os arquitetos expuseram sobre estes projetos. Neste segundo momento, da arquitetura conceitual, é processo de inferência, as relaçôes autorreferentes permitem movimentos nos dois sentidos, do geral ao específico e do específico ao geral, ou, nos termos que utiliza no texto Notes on Conceptual Architecture: Towards a Definition (EISENMAN, 2004b), do perceptivo ao conceitual e vice-versa. Partindo de outra premissa, que não seja a diagonal, teríamos outra estrutura autorreferente, cujo ponto de partida torna-se resultado e vice-versa. Como a crítica apontada por Robin Evans (1985), é necessário que aceitemos a narrativa morfológica de Eisenman para compreender seus projetos como propóe. Apesar de depender deste aceite da narrativa do arquiteto para compreender o projeto tal como propóe, esta situação é condizente com a busca do arquiteto por uma teoria aberta, uma vez que é menos restrita, há mais caminhos, consequentemente mais relações possíveis, sobretudo do específico ao geral do que no sentido contrário.

\subsection{House I, a critica ao desenho: ambiente total e autonomia da forma}

A análise desenvolvida até aqui foi deliberadamente restrita à visão que Eisenman apresentou da House I, presente no livro Five Architects (EISENMAN et al., 1975). Neste, a House I é apresentada junto à House II, projeto de mesma data que a exposição, 1969. Nesta apresentação, há a operação presente na atuação de Eisenman de projetar os seus projetos. Tal como rê-lê Terragni, também se submete à mesma possibilidade crítica. A apreensão da House I é atrelada à apreensão da House II. O material que apresenta das duas casas difere sensivelmente, indicando dificuldade da leitura proposta por Eisenman à House I. 
Para contrapor esta perspectiva, daremos voz ao Eisenman da Tese (EISENMAN, 2006c) frente ao projeto da House I. Em sua Tese, não aceita que o projeto parta de ponto arbitrário, como um deslocamento diagonal; o ponto de partida é a condição genérica do ambiente total. A House I é projeto de expansão de uma casa com propósito de abrigar coleção de brinquedos, mas os desenhos amplamente associados a ela, como os presentes no texto do Five Architects, apresentam apenas o cubo. Apesar de ser edificada em um terreno ermo, há uma preexistência que não aparece nos desenhos do cubo 9 , aparecendo, em vez disso, acanhada junto à extremidade de fotos.

A House I está localizada no fim de uma das laterais de edificação em forma de "U”, com pátio no vazio. Isso permite duas leituras do vetor externo: ou ele é a conexão direta do edifício existente ou é a diagonal do pátio aberto. Esta segunda opção é mais facilmente compreensível, pois aparecem situaçôes análogas nas análises que Eisenman faz em sua Tese, da Casa del Fascio principalmente, mas também do Säynätsalo Civic Centre. A condição da influência de uma edificação relevante tão próxima não é discutida na Tese. A House I é espaço anexo para expor coleção de brinquedos, pavilhão que amplia as funçôes presentes na casa. Ela guarda proximidade, em termos de função, muito maior com o edifício adjunto do que a Casa del Fascio com os edifícios contíguos. Neste projeto de Terragni, a relação é seguramente com a praça e as fileiras que marcharão a partir desta. A condição de anexo da House I poderia sugerir um eixo de acesso pelo edifício existente. Qual seja a situação no projeto de Eisenman, a forma genérica sugerida pelo eixo externo é linear, com vetor perpendicular ou inclinado à fachada do acesso. Há na House I a possibilidade de o eixo externo advir do acesso do lote, mas, caso a forma fosse desenvolvida a partir deste eixo, o acesso seria em outra fachada ou haveria flexóes mais complicadas atestando o deslocamento deste vetor.

Eisenman reconhece que espaços expositivos são variados em questão de necessidade funcional, não determinando uma forma centroide ou linear (EISENMAN et al., 1975, p. 15). O termo pavilhão remete a elemento de encerramento de um volume, de ampliação, e, portanto, de fechamento de composição. Como algo cuja função é fechamento, que encerra, não poderia ser linear, portanto o termo pavilhão remete a algo centroide, fornecendo a forma genérica a partir das demandas específicas. A condição genérica é de um cubo afetado por eixo externo perpendicular a este - situação análoga à que analisa na Casa del Fascio de Terragni.

Como as duas leituras diferem por questóes conceituais, mas utilizam um mesmo repertório de exploração formal, alguns pontos da leitura anterior podem ser reproduzidos. A leitura vista acima

9 Em sua tese, Gabriela Izar (2015) apresenta material obtido no Canadian Center for Architecture, no qual há implantação da House I junto à residência existente, mas materiais de publicações, ou da página do arquiteto na internet, por exemplo, apresentam apenas o cubo. 

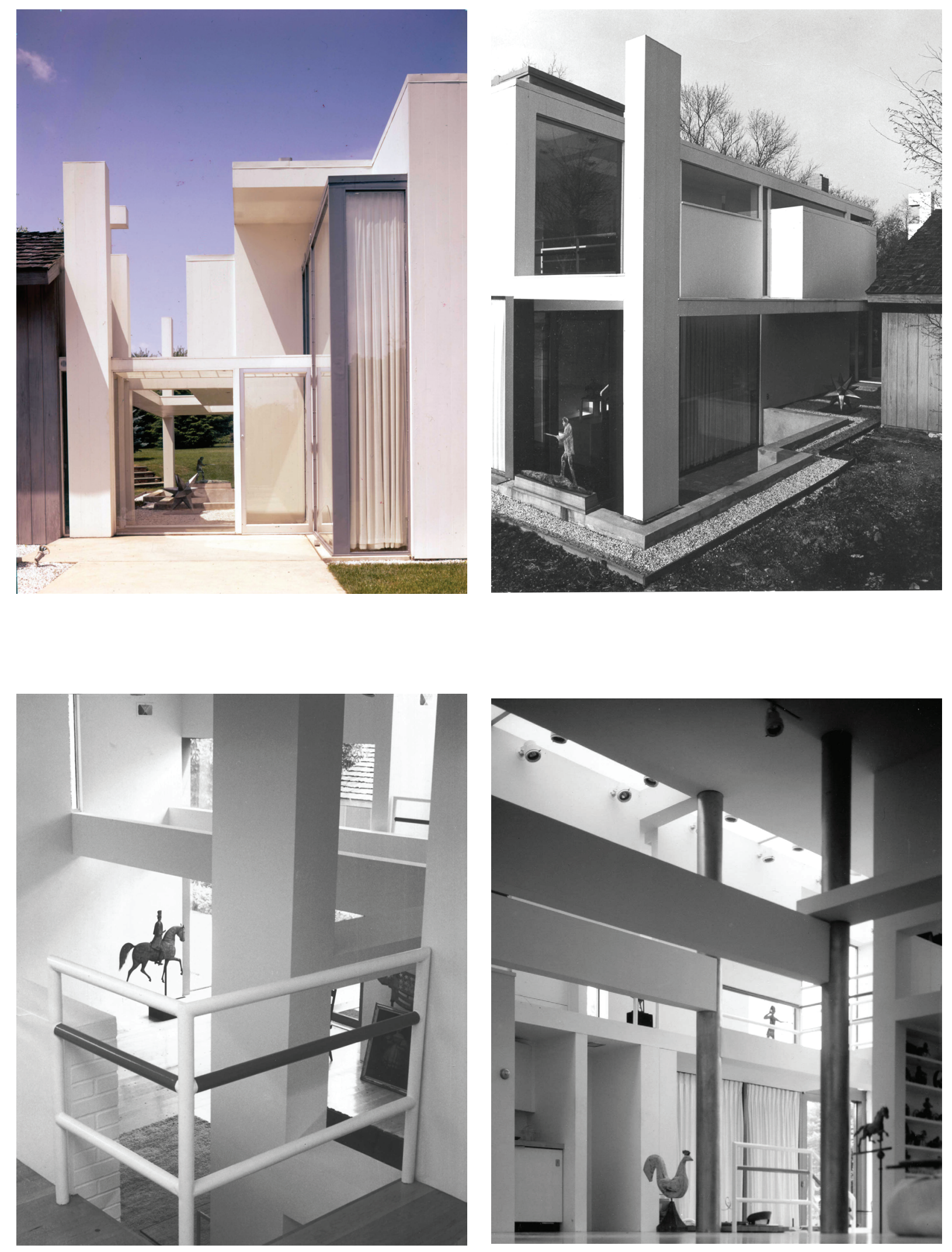

Figura 85 - Fotos da House I com pré-existência e fotos internas. Fonte: Site Eisenman Architects. 


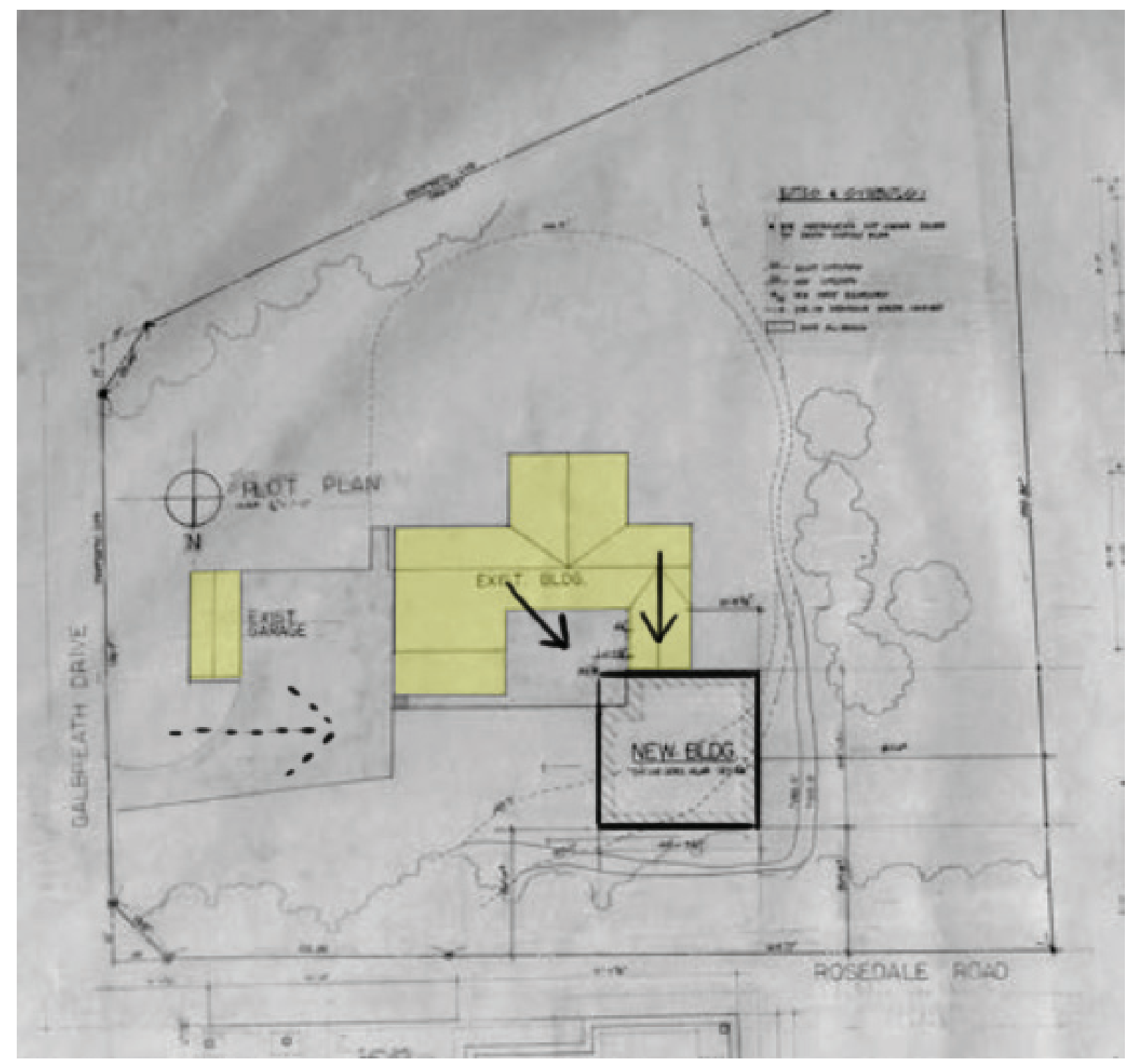

Figura 86 - Croqui da situação sobre desenho de implantação da House I. Fonte: Compilação do autor.

do vetor empurrando e despindo o volume na progressão opaco, translúcido e vazio, enquanto expóe os pilares e vigas no acesso, permanece, porém agora não vemos essa força a partir do efeito da diagonal, mas como consequência do vetor de acesso. Os pilares e vigas expostos marcam o eixo de acesso direcionando-o e dando-lhe força. Tal como ocorre na Casa del Fascio, esse eixo longitudinal estratifica o volume em sequência de planos, como um "baralho de cartas", marca o plano de fundo oposto como plano de referência e divide o cubo na vertical. Eixo marcado também pela presença de pilares apenas no sentido ortogonal a este eixo, exceto pelos pilares do acesso que marcam o vetor. Trata-se de uma operação de alinhamento dos pilares como ocorre no Asilo Infantile, de Terragni. A divisão do quadrado em planta em nove, com quatro eixos, dois em cada sentido, com espessura, 


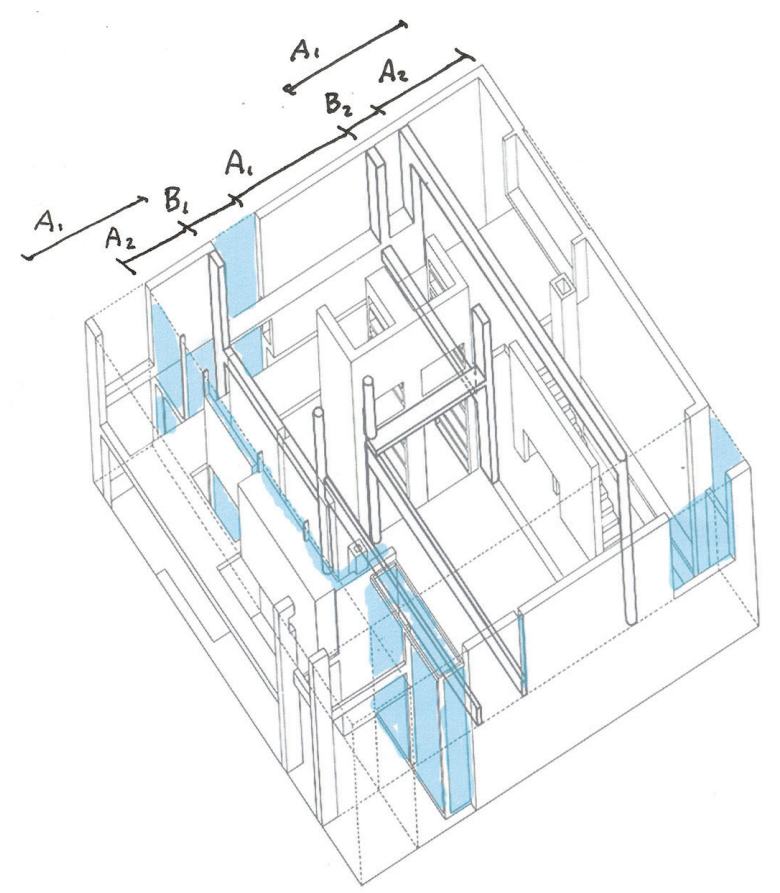

Figura 87 - Perspectiva isométrica com as aberturas e sequência ortogonal dos planos. Fonte: Compilação do autor.

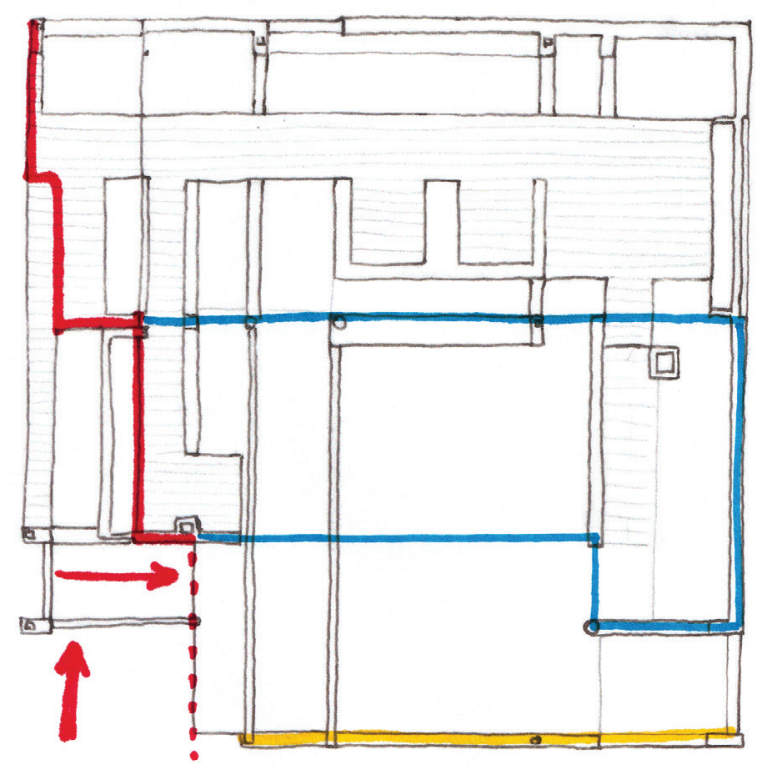

Figura 88 - Eixo externo alternativo. Fonte: Elaborada pelo autor.
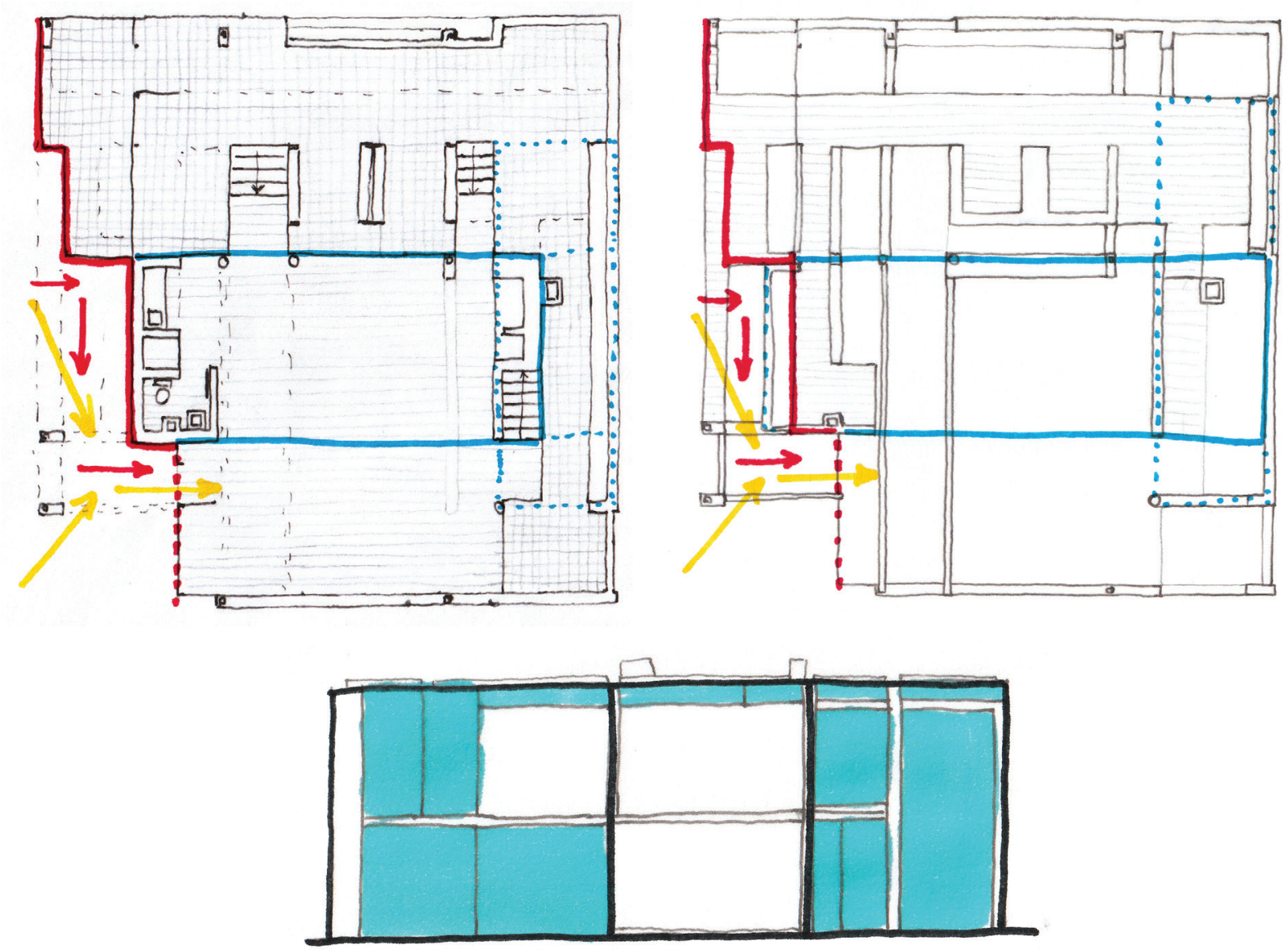

Figura 89 - Escalão, eixo de acesso e fachada tri-partida. Fonte: Elaborada pelo autor. 
também permanece. Ao empurrar a fachada de acesso, ocorre a compressão dos planos em direção ao plano de referência formando conjunto de sequências. Toda a leitura acima vista das sequências, de A1-B1-A1-B1-A1 a A2-B2-A2-B2-A2, permanece. Esta compressão é consequência da resolução da forma linear com um único acesso. A necessidade de equilíbrio por causa do acesso deslocado gera a saída para trecho rebaixado do térreo, equilíbrio da porta de acesso em relação ao eixo longitudinal.

$\mathrm{O}$ acesso único sugere que o primeiro movimento é iniciar amortecimento do eixo externo, seguido de movimento espiral para conformá-lo ao cubo, forma centroide. Um escalão composto pelo rebaixo do térreo e pelo volume de serviços empurra o acesso de posição no eixo central. Este escalão é relevante ao ponto de ser rebatido no primeiro pavimento. Tanto para a hipótese do vetor externo linear quanto diagonal, este escaláo direciona o acesso. Particularmente, à hipótese da diagonal, o volume central da divisão tripartida da fachada de acesso forma massa resistente que auxilia a dobrar o eixo. As características desta fachada - pano opaco ladeado por superfícies em vidro - reforçam a leitura deste volume central como massa.

Mesmo à hipótese fraca de o eixo externo ser o do acesso ao lote, ainda é possível que o escalão do acesso associado ao plano longitudinal forte, marcado pelas colunas e vigas expostas, dobre este vetor. Esta hipótese é considerada fraca porque o eixo já incidiria deslocado na lateral. Assim, o que deslocaria este eixo é o centro da fachada lateral, superfície opaca praticamente não flexionada, sem sinais de ser afetada pelo eixo, descartando essa hipótese.

Para conformar o eixo linear à forma centroide, Eisenman desenvolve uma espiral centrípeta cuja força e giro afetam todo o edifício. Primeira ferramenta para enfraquecer o vetor é eixo ortogonal a ele - eixo forte, marcado por toda a extensão, o amortece e marca o acesso ao rebaixo no térreo. Deste, o vetor chega ao vazio central; apesar de forma centroide, o eixo chega deslocado, mas é amortecido pelo alargamento. Em seguida, o movimento é contraposto a outro eixo ortogonal, este mais fraco, este segundo eixo ortogonal é encerrado precocemente pela marca de pilar no piso, e também direciona ao rebaixo no térreo. Estes dois eixos mais a escada formam escalão convexo que dobra o vetor em direção à escada, a primeira curva da espiral. Este movimento de curva aparece também no piso do volume da escada, que, recuado, termina em pilar junto à escada reforçando o escaláo. $\mathrm{O}$ volume negativo marcado pelo rebaixo no piso atrás da escada, indicado pela saliência na parede, impóe uma barreira final para o vetor, tal qual no primeiro volume do acesso da Cité de Refuge de Le Corbusier.

Espiral prossegue no pavimento superior; já a escada termina em patamar quadrado, forma centroide que amortece o movimento. Este patamar é ligeiramente comprimido na direção do 


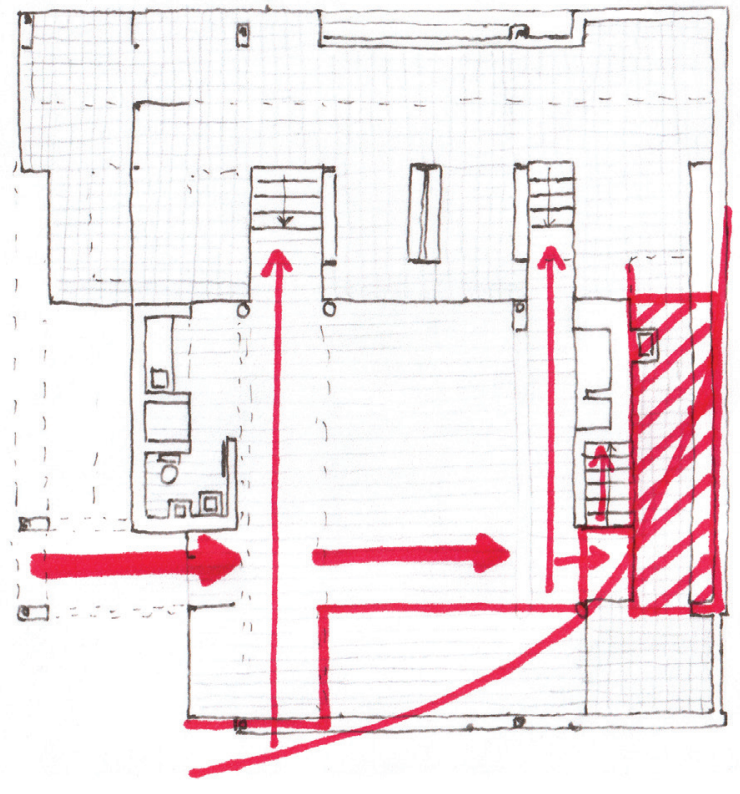

Figura 90 - Início da espiral no térreo e primeira curva. Fonte: Elaborada pelo autor.

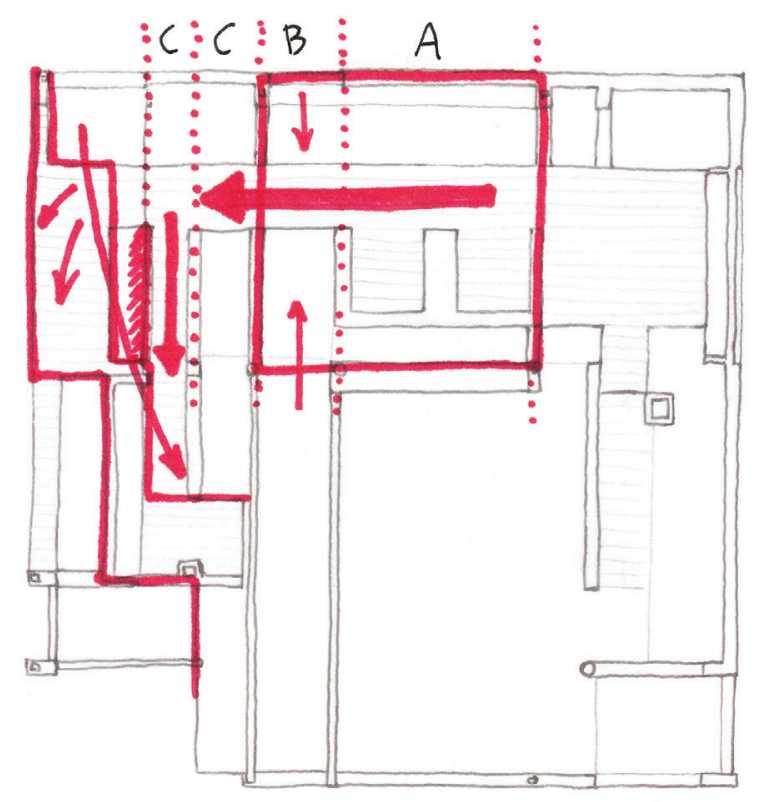

Figura 92 -Terceira curva da espiral no primeiro pavimento. Fonte: Elaborada pelo autor.

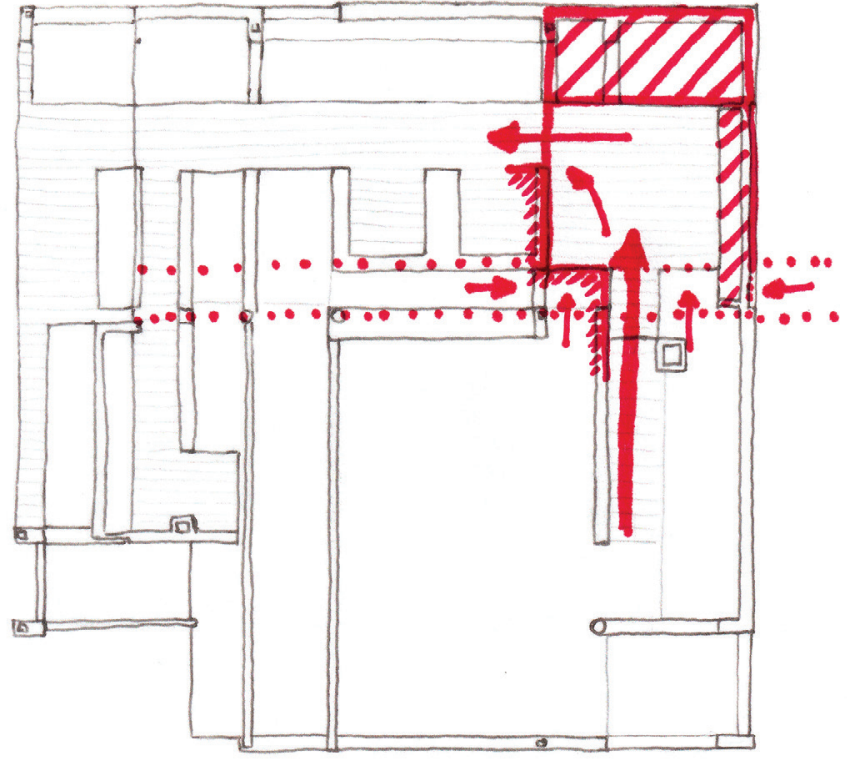

Figura 91 - Segunda curva da espiral no primeiro pavimento. Fonte: Elaborada pelo autor.

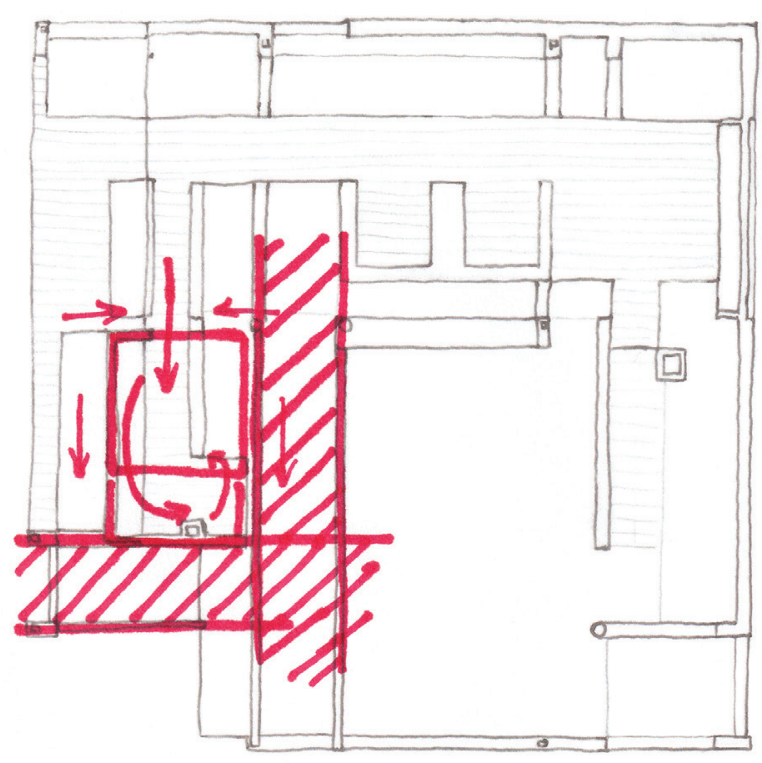

Figura 93 - Movimento final da espiral no pavimento superior. Fonte: Elaborada pelo autor. 
movimento da escada, indicando a força do vetor e marcando essa fachada lateral como plano de referência no sentido ortogonal. $\mathrm{O}$ volume indicado na lateral deste patamar marca o que seria sua dimensão não comprimida. Esta compressão forma volume transversal que enfraquece o vetor com plano imediatamente ao término da escada. Tal qual no térreo, este é um dos quatro eixos que divide o quadrado da planta em nove. Há um volume negativo ao fundo o qual junto com o volume que marca o quadrado na lateral direcionam o movimento para a segunda virada. Esta não sai centralizada ao quadrado, a curva é reforçada e sua direção corrigida por pequeno escaláo formado pelo recuo do piso e por volume opaco.

Após a segunda curva, o vetor passa por sequência de planos que formam progressão A-B-C, a qual, diminuindo de tamanho, gera movimento de parada. Nesta sequência, passa por outro quadrado e pelo plano ortogonal forte, amortecendo o eixo. A virada é consolidada por plano composto por recorte no piso e por trecho protuberante na fachada junto ao escalão do acesso. A dificuldade em dobrar o vetor aparece em parcela dele que "escapa" e vai além do pano de vidro, compondo parte do escalão que afeta o acesso, ao mesmo tempo que esta forma é escalão responsável por puxar o vetor para a terceira curva. Uma extensão opaca na fachada frontal contém e reforça a dobra deste eixo. Este trecho opaco indica a pressão que essa espiral exerce nesta fachada ao fazer saltar parte opaca onde seria vidro no primeiro pavimento.

Seguinte à terceira curva, o vetor passa por plano composto por viga horizontal e recorte na fachada que enfraquece o vetor. Por fim, o movimento espiral esbarra no eixo de acesso, o qual oferece barreira. Neste choque, há volume em forma centroide, ponto de parada, esticado pelo vetor que o arrasta, enquanto faz uma última pequena virada que o finaliza comprimido ao eixo forte ortogonal e ao centro da casa. Saliência que não toca a viga, indicando, pela não junção dos elementos, o choque entre dois elementos distintos, além de apontar que este último plano, da viga, encerra o vetor.

Ao fim do movimento, identificamos que a espiral é articulada pelo vazio central, este funciona como seu travamento. A espiral aparece nas sequências tripartidas: o quadrado central é a fixação, cada uma das extremidades é uma curva, enquanto os quadrados intermediários são trechos de reta e amortecimento do vetor. Essa espiral é semelhante a que Eisenman identifica no Säynätsalo Civic Centre de Aalto: o início por vetor deslocado de eixo central e oriundo de vetor externo em diagonal, o travamento por um pátio e o movimento de encerramento como um choque da espiral com seu início e a pressão no centro.

O sistema de volumes, que, como vimos, Eisenman afirma, em sua Tese, estar presente em toda 


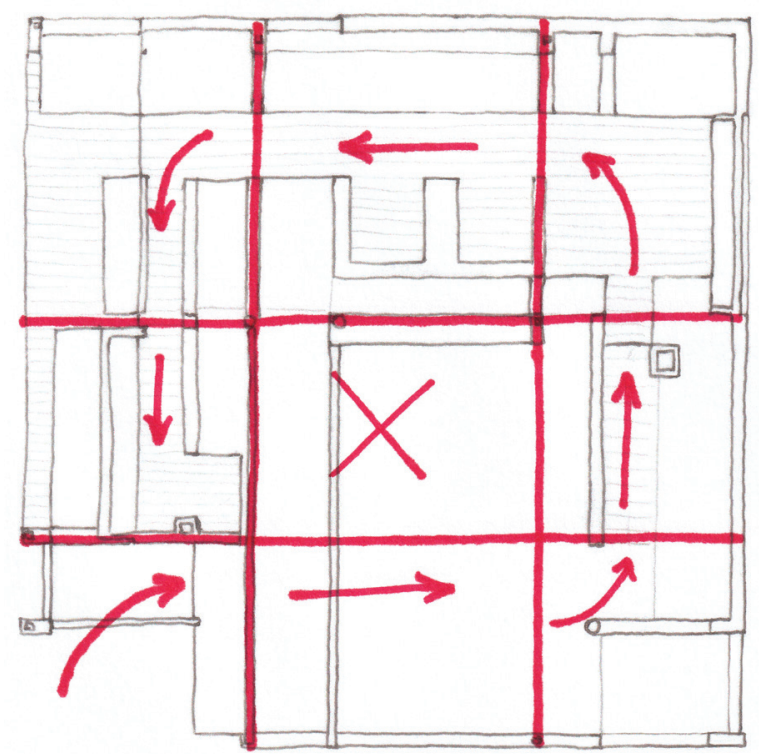

Figura 94 - Espiral na divisão tripartida. Fonte: Elaborada pelo autor.
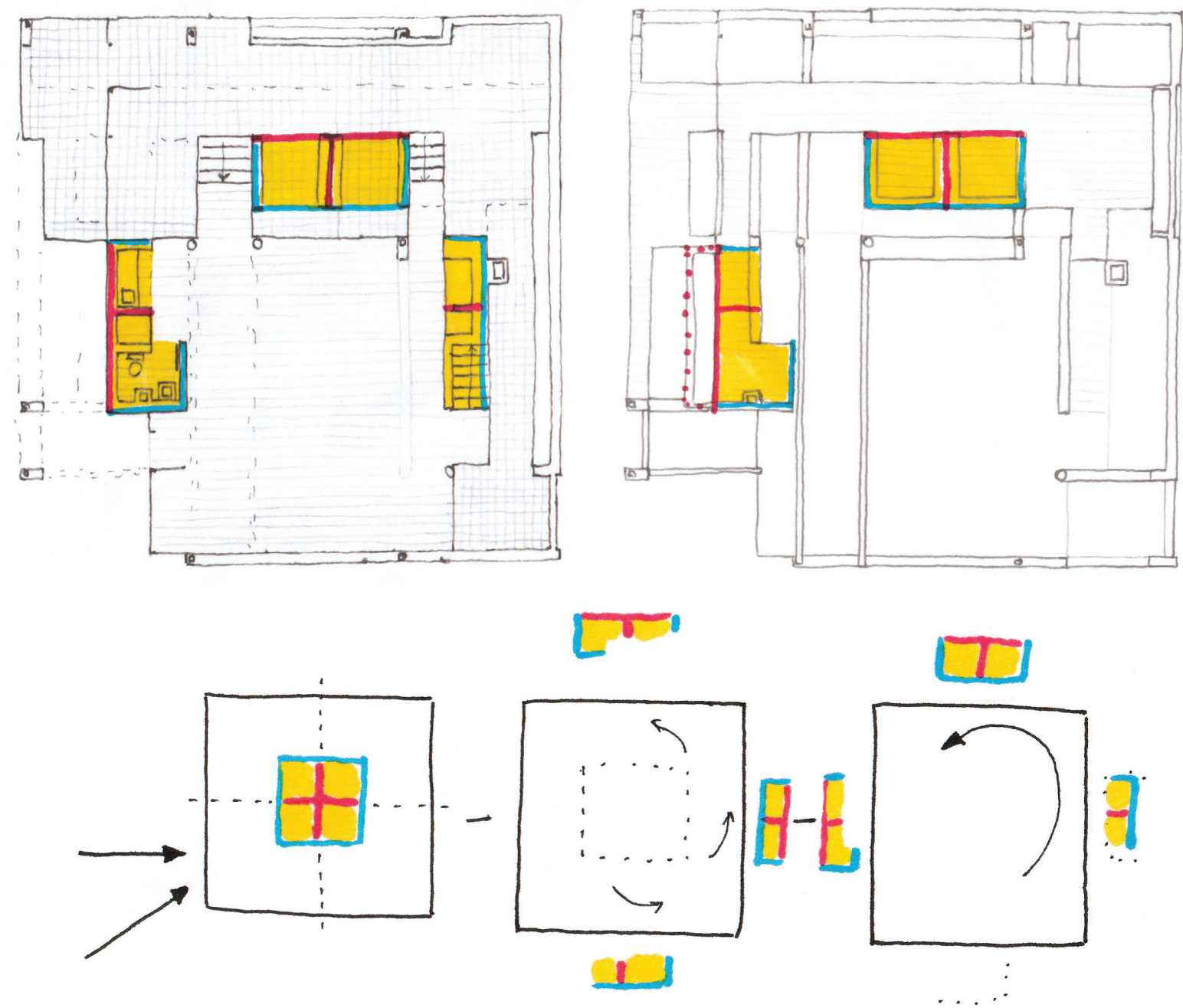

Figura 96 - Volume central da forma genérica fragmentado e cata-vento. Fonte: Elaborada pelo autor. 
arquitetura, tambem é afetado pelo eixo externo. A análise deste sistema sugere que a forma genérica possuía no centro volume como massa. Os volumes de serviço, da lareira e o de estar sugerem uma forma quadrada única, marcada em seus dois eixos, que é fragmentada e rotacionada pela força do eixo de acesso; forma, assim, um cata-vento parcial fixado pelo mesmo vazio central. O cata-vento, sistema que Eisenman diz ser organização volumétrica sugestiva de movimento, reforça a espiral e marca o sistema de movimento como principal. A dimensão dos fragmentos mostra a sequência do impacto: primeiro a lareira, em seguida o volume de serviços e, posteriormente, o volume de estar; este último, menos afetado pela força já amortecida, resta com maior dimensão, metade do volume inicial. As divisóes internas destes volumes auxiliam a leitura.

A leitura de volume que rompe e é deslocado por vetor incidente é semelhante a como Eisenman encontra na Martin House de Wright. Por sua vez, a leitura de que a forma genérica possuía uma massa no centro deslocada na forma específica, resultando em um pátio central que articula espiral, é como a encontrada no Säynätsalo Civic Center de Alvar Aalto. A partir desta referência, também é possível compreender o volume sem muitas flexóes junto à fachada lateral mais próxima do acesso. Como no projeto de Aalto, no qual a diagonal recorta o volume da biblioteca, na House I o acesso incidindo em diagonal recorta este volume lateral, parcela menos flexionada do projeto.

Este movimento de giro da diagonal forma também o primeiro pavimento e o rebaixo no térreo. Esta porção originalmente do piso térreo é rotacionada e deslocada verticalmente ao deslizar sobre este piso: uma forma em "L" que será comprimida ao eixo do acesso, reiterando o aumento da porção final da espiral, excesso de massa comprimida. O rebaixo no térreo é a ausência desta porção. Marca disso é o tratamento do piso igual no térreo e no primeiro pavimento e diferente no rebaixo; neste último, é como uma superfície exposta após remoção da anterior. Um exemplo de como as operaçóes afetam até detalhes menores: o piso do térreo é linear, direcionado a partir do movimento do acesso, enquanto o do rebaixo é grelha, como uma superfície, uma malha genérica.

Encontramos esse deslocamento vertical também nos três volumes fragmentados. A lareira traz parede retangular, não segue a inclinação da escada, enquanto o volume da sala de estar ao fundo e o volume de serviço aparecem arrastados, esticados, nos dois pavimentos.

Interessante a ambiguidade que Eisenman forma em relação à diagonal. Em sua Tese, considera que o sistema espiral reconhece a diagonal, mas o cata-vento não a expressa, resultado da equivalência dos lados. O arquiteto reforça que o sistema principal é o de movimento, o sistema de volumes é subordinado a este. O cata-vento do sistema de volumes é parcial, haveria uma quarta perna.

É possível um terceiro sistema que articula a diagonal aumentando a ambiguidade. Encontramos 

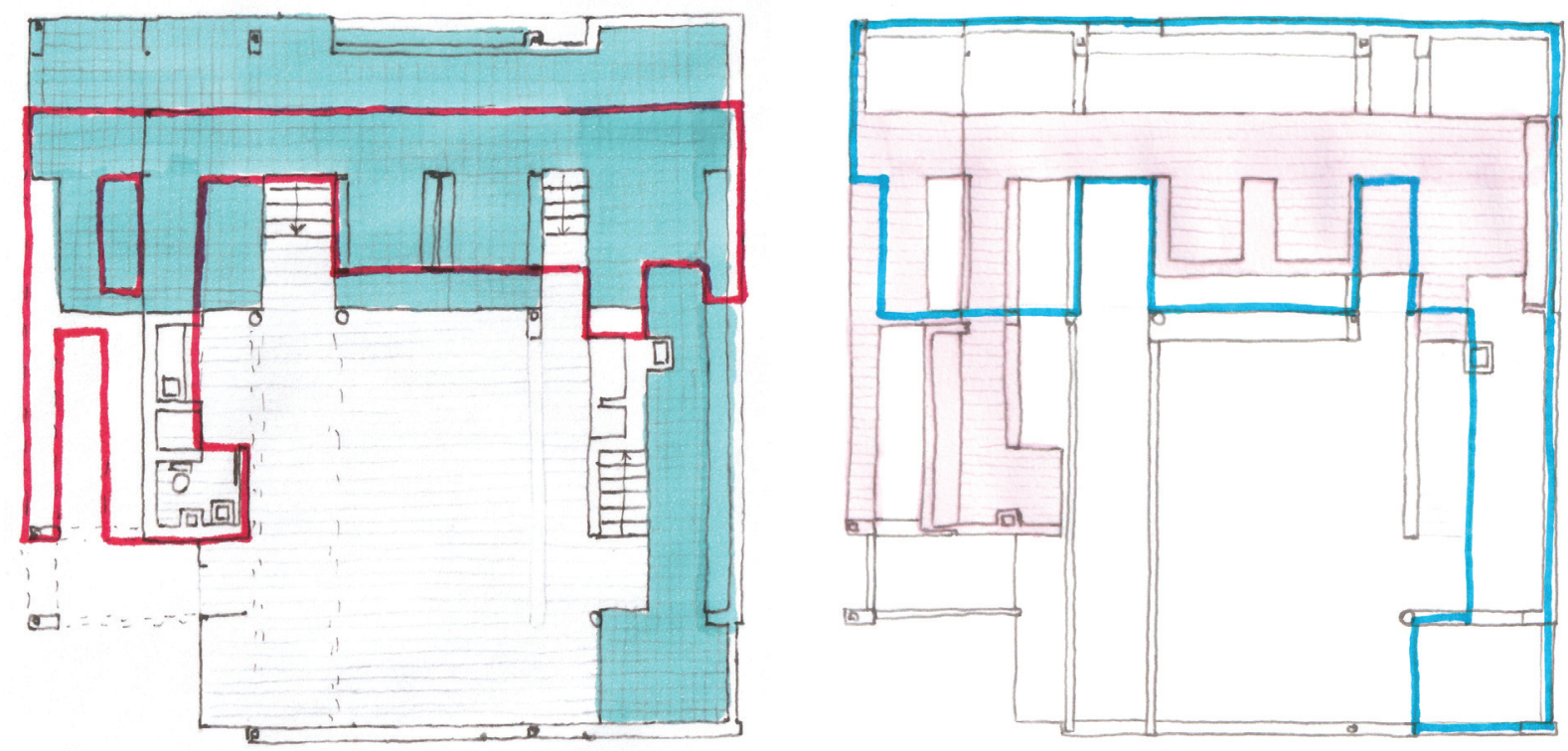

Figura 97 - L deslocado do térreo para o primeiro pavimento. Fonte: Elaborada pelo autor.
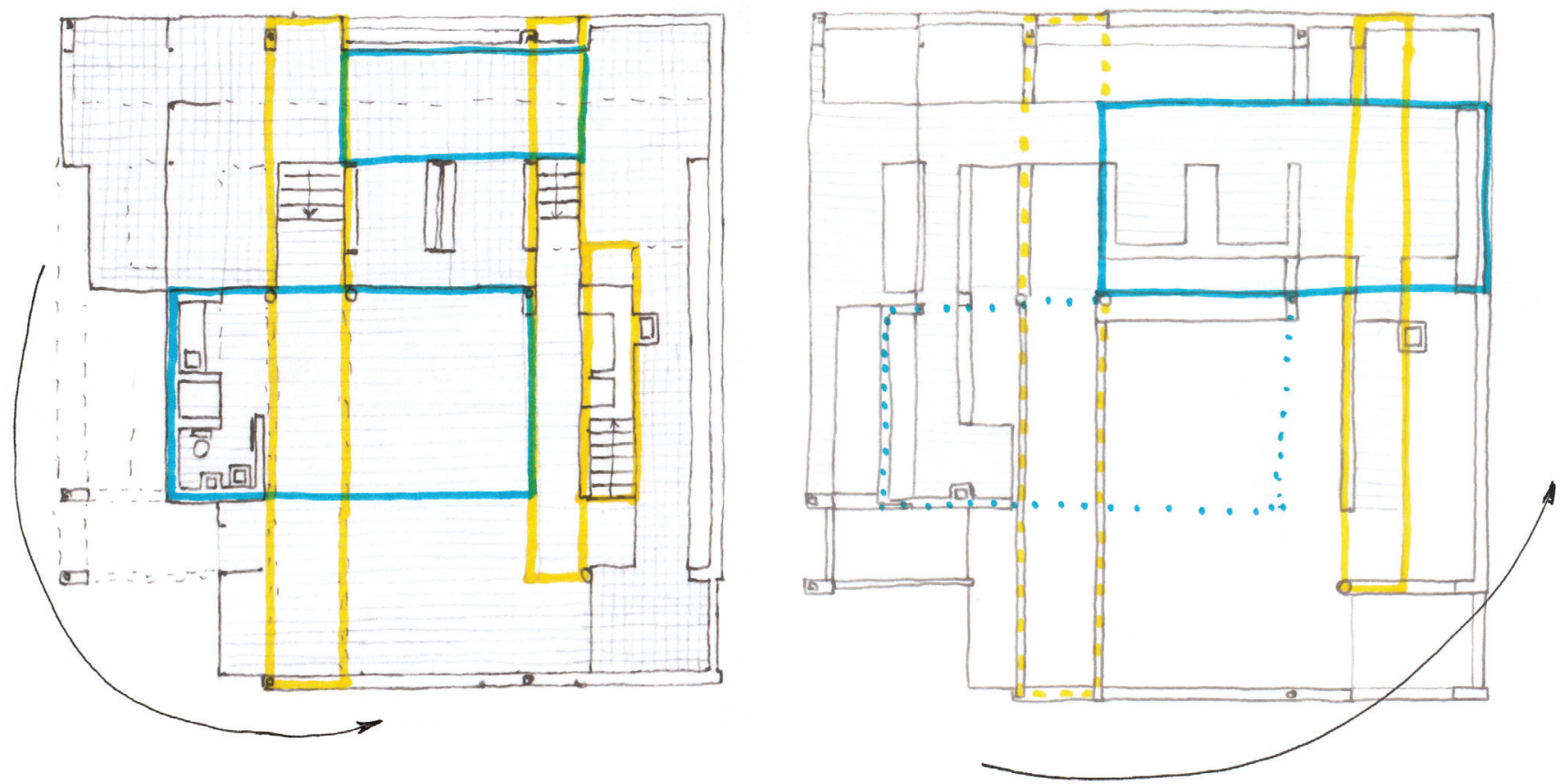

Figura 98 - Grelha de volumes intercalados. Fonte: Elaborada pelo autor. 

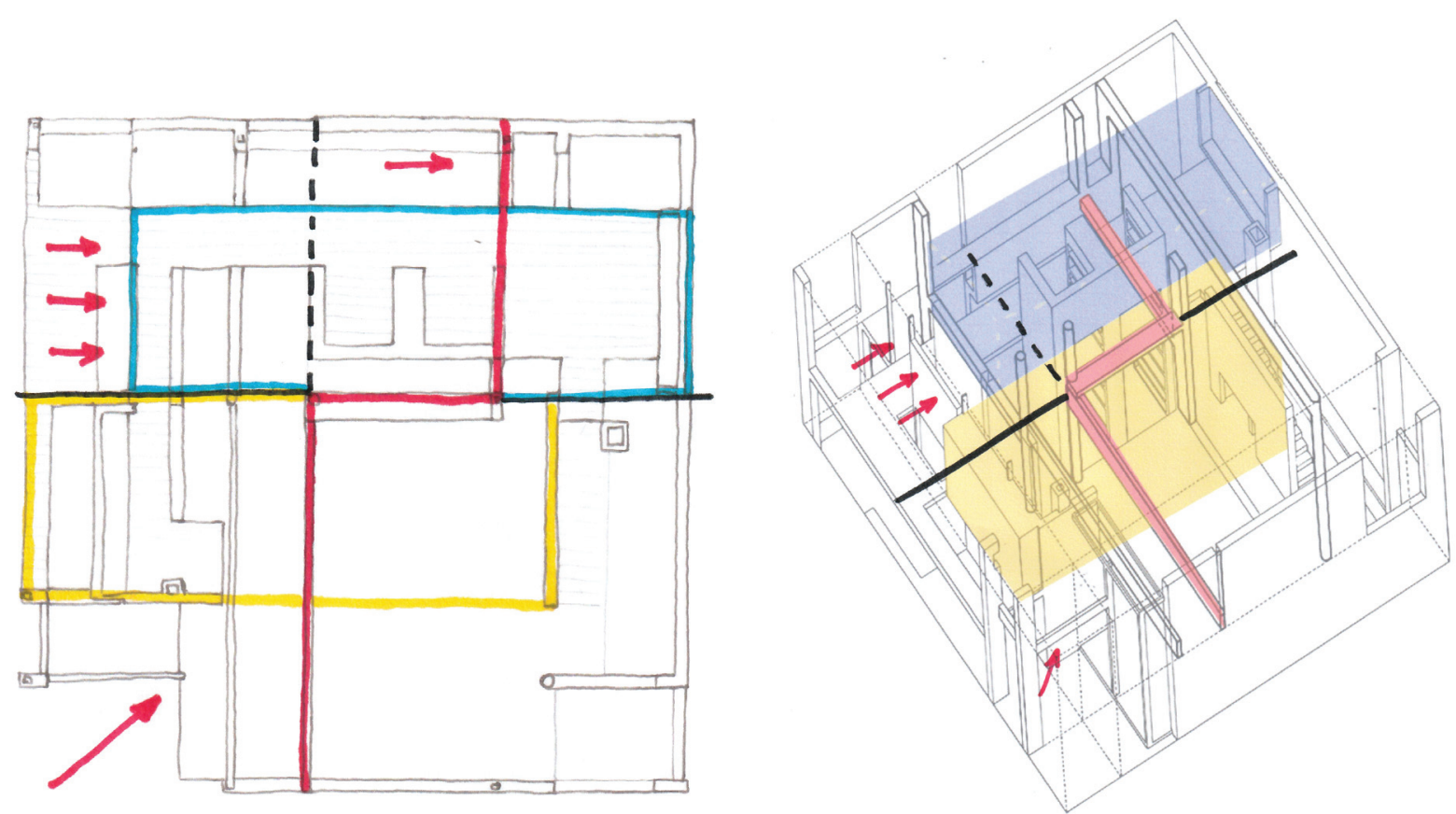

Figura 99 - Deslocamento de eixo, vigas e volumes na diagonal. Fonte: Elaborada pelo autor.

articulação, que Eisenman cita em sua Tese, como forma de reconhecer a diagonal e resolver seu efeito por meio de sistemas de volumes intercalados nos dois sentidos da malha: em um dos sentidos volumes; e no outro, movimento. No sentido longitudinal, temos um volume no rebaixo do térreo, pouco definido, um no térreo e um no primeiro pavimento, formando sequência em ascensão. $\mathrm{O}$ sistema de movimento intercalado se dá a partir dos planos das escadas - a viga marcada no chão do térreo mostra o início deste sistema, marca primeiro volume de movimento, ortogonal e "enterrado", e segue para volume no rebaixo do térreo no sentido longitudinal; em seguida, a próxima escada marca volume de movimento ascendendo ao térreo. No térreo, há volume marcado pelo volume de serviços. O volume da escada é o último movimento, junto com o volume no primeiro pavimento marcado por reentrância na fachada, ambos finalizam esta espiral.

Por esta leitura a partir do vetor externo, a diagonal que Eisenman apresenta no texto sobre a House I, inclusive o deslocamento conceitual entre dois quadrados, é resultado das flexôes da forma para acomodar o eixo externo ao cubo. A diagonal presente nas vigas no nível do primeiro pavimento é fruto do deslocamento entre os dois volumes longitudinais do térreo e do primeiro pavimento deste último sistema que vimos articular a diagonal. Diferentes flexôes aqui vistas resultam nas vigas que formam a diagonal - a viga horizontal, por exemplo, marca fundo do volume central que resiste à força da diagonal externa; a viga menor ao fundo é lateral de um dos quadrados que amortece a espiral, já a outra viga compõe o plano ortogonal principal.

Percebemos, ao longo da análise, que o equilíbrio deste movimento não é a partir de um 

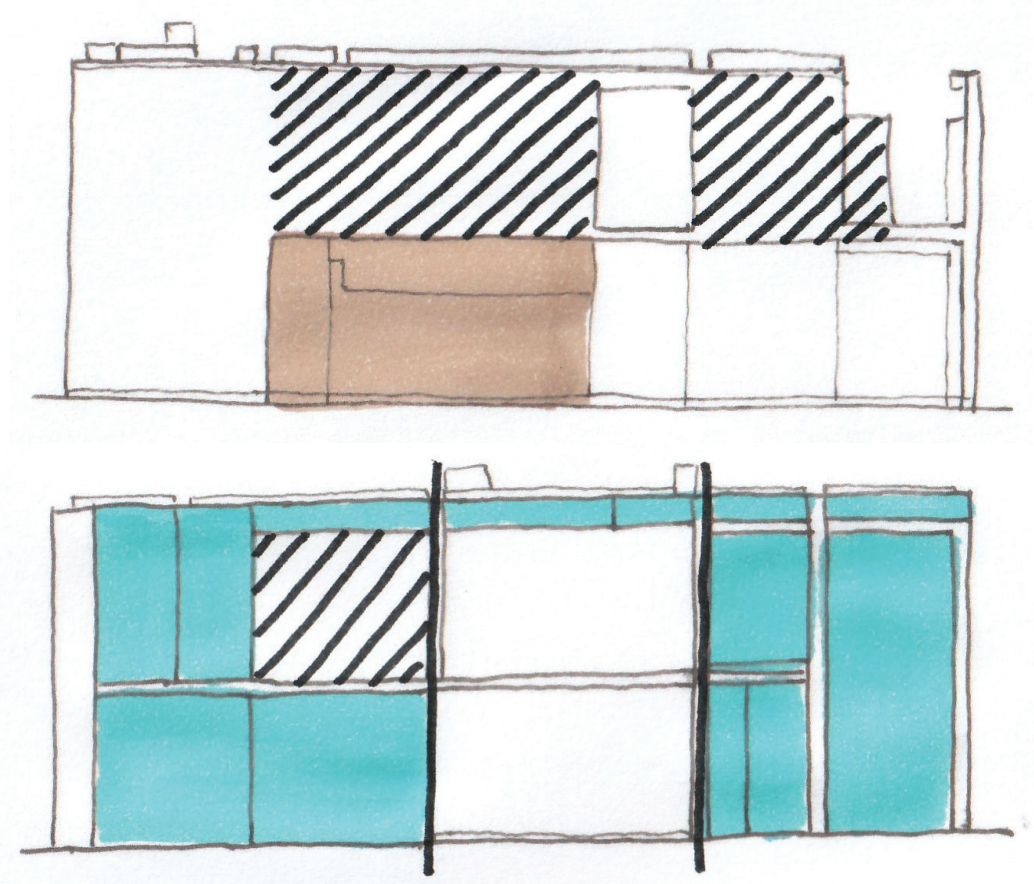

Figura 100 - Espiral aflorando nas fachadas. Fonte: Elaborada pelo autor.
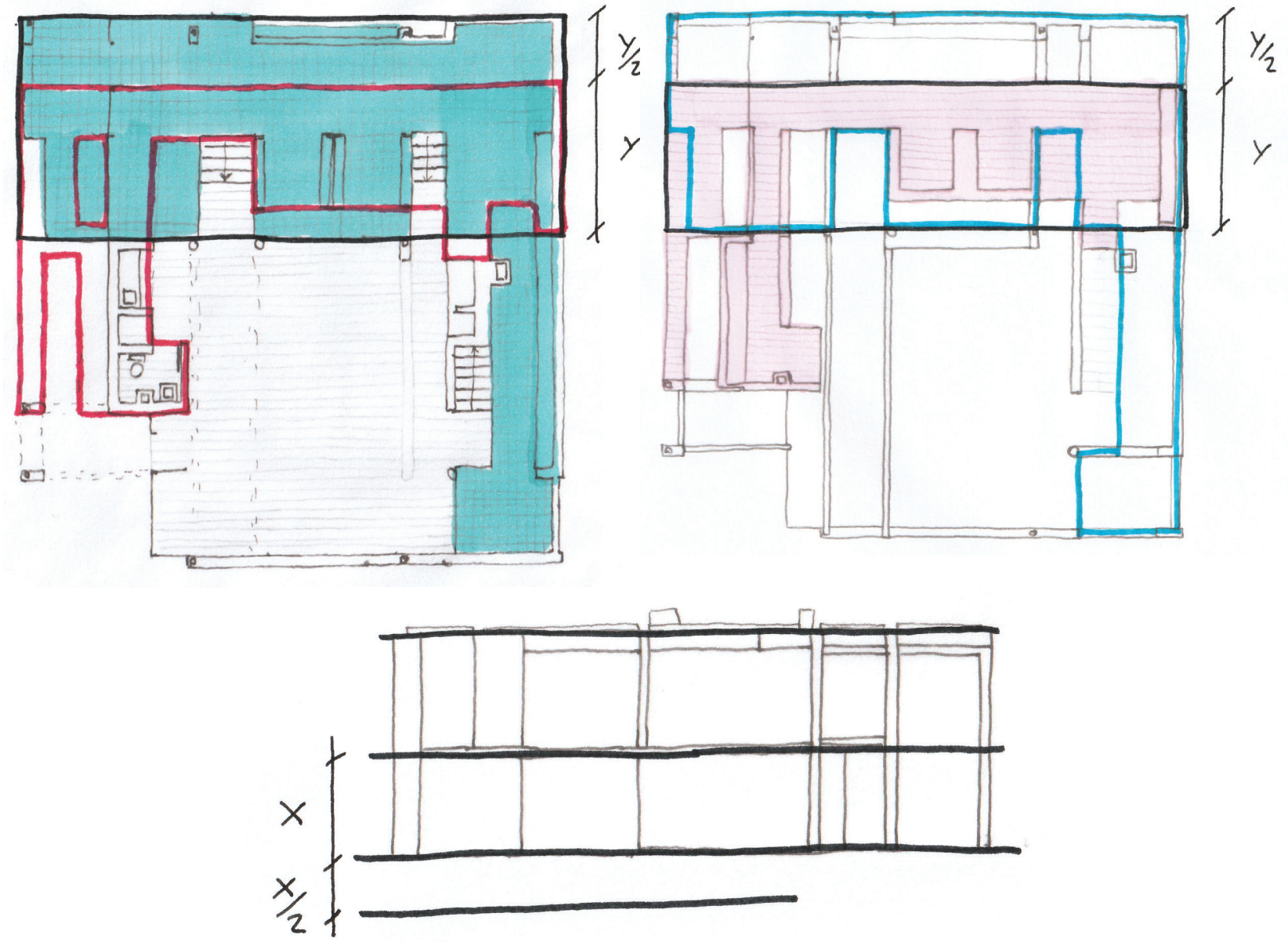

Figura 101 - Equilíbrio horizontal. Fonte: Elaborada pelo autor. 
acesso central, desta forma, o movimento todo "pende" para um dos lados do quadrado da planta, tendo forte semelhança com a análise do Säynätsalo Civic Centre. Essa condição arrasta as formas no sentido da diagonal explicitada pelo arquiteto, o que condiz com o comentário em sua Tese de que a tentativa de trabalhar uma diagonal a partir de uma espiral resulta em uma distorção da forma no sentido da diagonal. O quanto o movimento espiral afeta a forma aparece na fachada principal e em uma das laterais. Além do desequilíbrio da divisão tripartida da fachada principal que vimos acima, a lateral correspondente ao ponto onde a espiral se desenvolve no primeiro pavimento também é empurrada pela espiral. Nesta lateral, também há volume opaco, no primeiro pavimento, que estica sobre vidro no térreo, também distorcendo a divisão tripartida; volume que avança inclusive além da parte abaixo, tensão da espiral tentando "vazar" neste ponto, mas sendo segurada pela fachada.

Resta analisar a referência horizontal. $\mathrm{O}$ vazio central aparece como referência à série de deslocamentos, seja fixando o cata-vento, seja fixando a espiral, por exemplo; o vazio central funciona também como referência horizontal. O rebaixo no térreo e o primeiro pavimento são equilibrados em relação ao térreo. $\mathrm{O}$ friso externo junto ao solo reforça a leitura deste plano como referência horizontal. A diferença de altura entre eles é consequência da maior dimensão do rebaixo, proporcionando menor alavanca em relação ao eixo do térreo; novamente semelhante ao Säynätsalo Civic Centre, cujo pátio central articula as diferentes coberturas. A altura do edifício, que não fecha a forma do cubo, é resultado de operaçáo como lê na Casa del Fascio, o eixo externo perpendicular ao cubo o corta, expressando pela menor altura a linearidade da forma genérica externa.

\subsection{House I, o projeto como pesquisa}

A partir do acima visto, percebemos que a House I aceita as duas leituras, tanto a guiada pelo texto presente no livro Five Architects (EISENMAN et al., 1975) quanto a pautada pelos preceitos da Tese The Formal Basis of Modern Architecture (EISENMAN, 2006c). Não há pretensão de definir qual leitura é correta, não seria possível tal definição. A ambiguidade defendida por Eisenman é essa pluralidade de leituras, sem uma que se estabilize como definitiva. Além disso, as leituras aqui esboçadas não contemplam o "como” Eisenman desenvolveu este projeto, elas sondam estruturas formais existentes no projeto. Se retomarmos desenho de esboços do arquiteto, encontramos alguns elementos como pilares segurando volumes que formam notaçóes as quais não encontramos no projeto final nem traços delas ou elementos semelhantes.

Por este desenho também apreendemos que o compreendido da sequência de compressão no 
eixo ortogonal não reconstitui o modo como Eisenman chegou a essa compressão. O processo mental de compreensão da estrutura da forma, como proposto por Eisenman e como estamos exercitando, não remete, não coincide, ao processo de elaboração. Sondar o devir do objeto é diferente de sondálo presente, e o objeto, a House I, resiste a ser reduzido a qualquer uma dessas leituras. Como vimos (Capítulo 2), encontramos esta questáo desde a Tese, quando diz que suas análises de projeto não visam a corroborar ou negar o que os arquitetos propuseram, mas compreender seu sistema formal, passando pelo From Object to Relationship II (EISENMAN, 1971), quando diz que sua análise não depende de Terragni ter pensado a partir da estrutura que propóe, até chegar, particularmente, no Dall'Oggetto alla Relazionalità (EISENMAN, 1970a), quando cita Barthes para defender o método estruturalista como uma recomposição do objeto. Eisenman elabora leituras paralelas à proposta, paralelas à formulaçáo dos autores, mesmo que o autor seja o próprio Eisenman, portanto, consiste em um outro ponto de vista acerca do mesmo objeto. Gabriela Izar (2015, p.299) aponta esta questão na série de casas, reforçando a dificuldade em acessar o processo de formulação, diz que os diagramas de formação são ocultados pela narrativa da forma final.

A partir desta irredutibilidade do objeto, desta autonomia do objeto, que Eisenman pode retrabalhar seus projetos em suas cronologias. O objeto formado não guarda relação unívoca com processo de formaçáo tampouco com os processos de leitura. Eisenman diz que a diferença entre seus diagramas para a Casa del Fascio e para a House I é apenas que os primeiros eram sobre um objeto existente, já os segundos ao mesmo tempo que analisou produziu o projeto (EISENMAN, 1999, p. 56). Esta similitude permite que extrapolemos o mesmo comentário que faz sobre seus diagramas do projeto de Terragni, ao longo dos anos, aos seus: “[...] esses diagramas [Casa del Fascio] foram revisados e redesenhados tantas vezes nos últimos trinta anos, que tentar qualquer interpretação de seu estado original é agora algo um tanto incerto.” (EISENMAN, 1999, p. 53, tradução nossa). É possível pelo diagrama encontrar uma forma, processo de elaboração, mas, quando encontrada, haverá outros diagramas que a explicam, ou que a reconstroem, processos de leitura.

Procedimento semelhante ao que identificamos na House I. O aqui proposto é que a House I foi importante ponto de reflexão de Eisenman para chegar a suas pesquisas da estrutura profunda e, consequentemente à House II; inclusive foi a partir deste segundo projeto que a House I foi relida - a House I é lida como arquitetura conceitual posteriormente, apenas quando junto à House II. A primeira casa parte de leitura como apresentada em sua Tese, mas seu desdobramento, sua leitura, chega à estrutura profunda e à House II. Ao desenvolver o projeto da House I, estudá-lo, Eisenman lê a possibilidade de operação da diagonal, assim, a House II é o estudo deste movimento, mas de 128 
forma arbitrária, termo utilizado ao descrever operaçóes iniciais deste projeto com mais clareza do que ao destacar a diagonal da House I (EISENMAN et al., 1975). Tal processo podemos creditar ao uso do diagrama. Eisenman mobiliza ferramenta oriunda de tradição formalista, a partir de Rowe, que a utiliza para leitura, para análise, mas embaralha o processo de projeto e de análise. Cada projeto é também crítica, análise de si. Uma característica que permite esta transição, na qual a House I corresponde tanto às bases formais apresentadas na Tese quanto à arquitetura conceitual de Eisenman, é a permanência do modo de leitura. Em sua Tese, já expõe modo de ler a forma, seja através dos diagramas, seja a partir da forma de compreender o espaço como plano e volumes positivos e negativos. Exemplo disso é como as formas que lê projetos de outros arquitetos em sua Tese subsidiou com ferramentas formais ambas as leituras aqui realizadas.

A leitura apresentada pelo arquiteto da House I procura omitir o entorno o que condiciona a apreensão deste, operação que reforça a hipótese de influência da Tese no desenvolvimento deste projeto. Com isso, temos como diferença fundamental, que indica essa mudança entre os dois projetos, o fato de o deslocamento da House I resultar da interação de demandas externas e internas, do vetor de entrada da House I, condição na qual os dois quadrados são instâncias, no tempo, do mesmo quadrado deslocado, ao passo que na House II não há o externo, a diagonal surge da sobreposição de repetição da malha, há dois quadrados. Neste sentido, a House I e a House II são exploraçôes sobre um mesmo cubo, dois "passos" a partir do cubo da Casa del Fascio de Terragni.

A referência à Casa del Fascio permite outra distinção. Quando Eisenman analisa este projeto em sua Tese (EISENMAN, 2006c), mesmo havendo dialética massa-superfície, valoriza a unidade, todas as formas se inter-relacionam e se influenciam de maneira categórica, dedutiva, do acesso, ao pátio, à janela extrudada na fachada anterior; já seus comentários sobre este mesmo projeto no texto From Object to Relationship II (EISENMAN, 1971) reconhecem como modo de acessar a estrutura profunda elementos separados, as fachadas não têm a mesma unidade com o interior. Ao observarmos a malha (grid) e a diagonal motivadora das operaçóes formais entre a House I e a House II, encontramos esta diferença. A malha na House I deforma-se com as formas, como em suas análises na Tese; a ideia de absoluto do ambiente total, o sistema formal é uno, articulando forma genérica e específica. Na House II, ao contrário, o grid é tautológico, ele aparece e força a forma. Como vimos, a divisão do quadrado em nove na House I se deforma, os planos são empurrados e distorcidos; se compararmos a diagonal da House I com a diagonal da House II, a partir desta divisão do quadrado inicial em nove, percebemos a diferença: a primeira, em certo sentido acanhada, é ligeiro ruído na forma, enquanto a segunda afeta incisivamente a forma, marcando fortemente o edifício. 

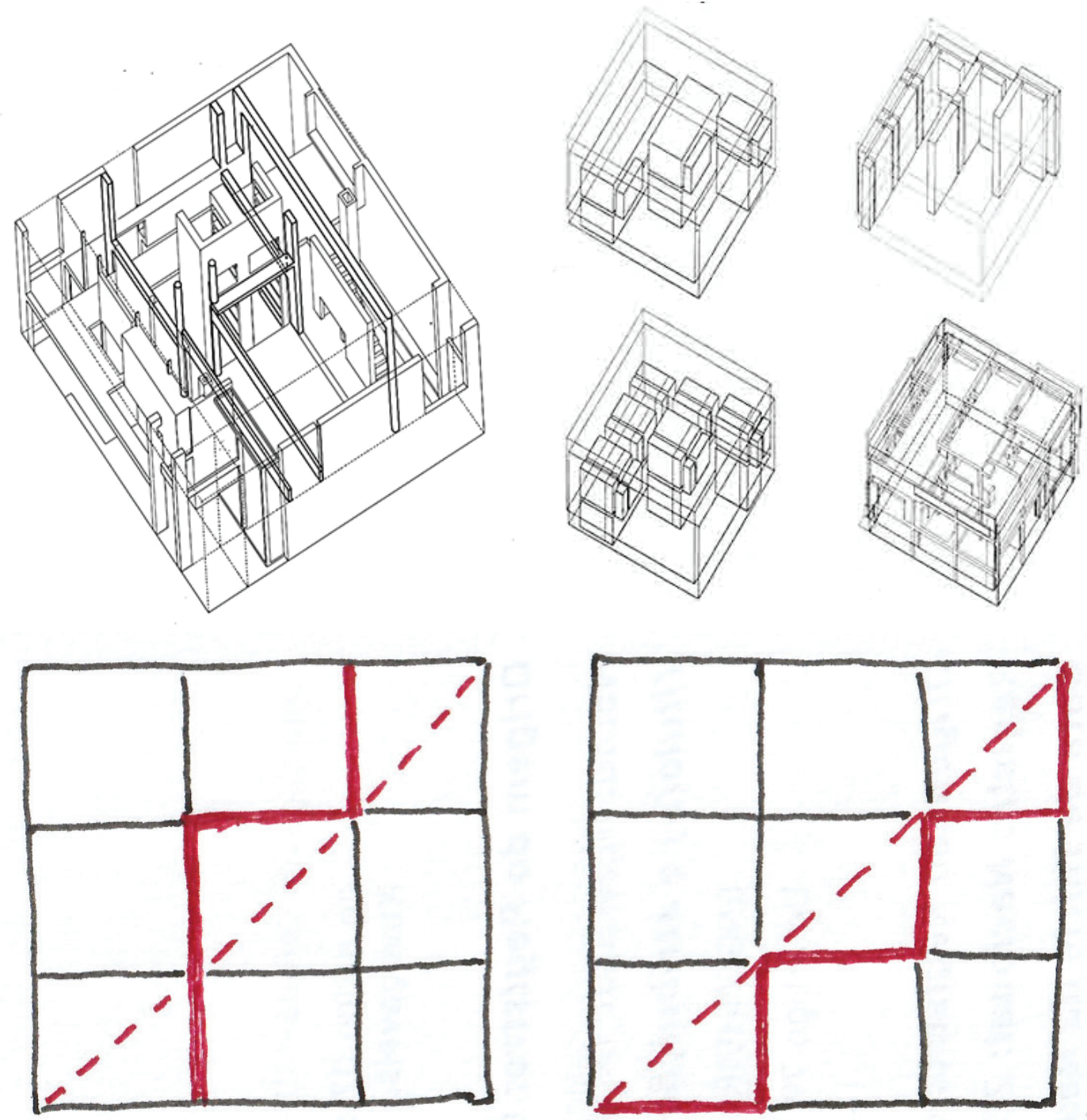

Figura 102 - Comparativo entre a diagonal da House I e da House II. Fonte: Compilação do autor.

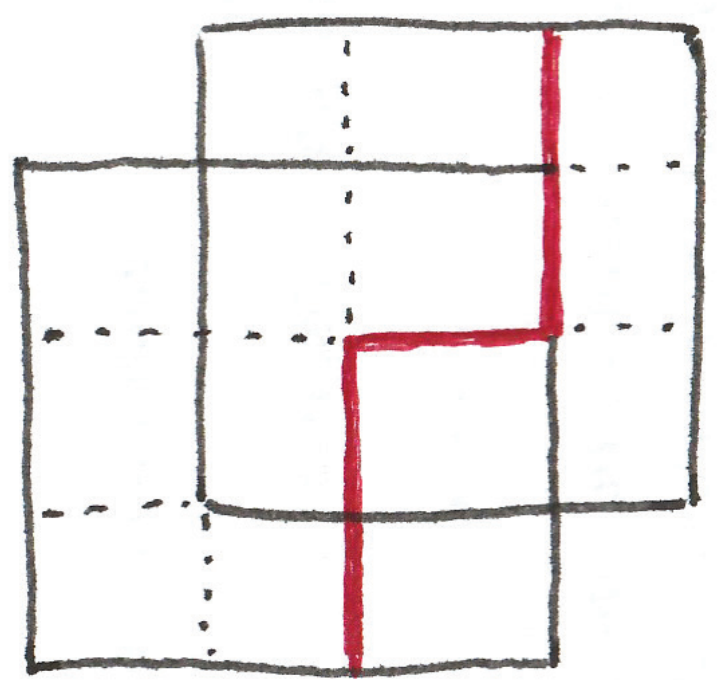

Figura 103 - Diagonal House I como o deslocamento de dois cubos tripartidos. Fonte: Elaborada pelo autor. 
Considerando a motivação descrita por Eisenman para a diagonal da House I, o deslocamento entre os dois cubos na House II é sutil, mas a diagonal é incisiva, ao passo que o deslocamento entre os cubos na House I é intenso, mas a forma final da diagonal é tênue, seja na planta dividida em nove, seja no deslocamento de dois cubos em perspectiva isométrica. Pela intensidade que marca a forma, a diagonal da House II condiz mais com o movimento inicial, como motivo das transformaçóes da forma. Podemos observar isso através de outra leitura sugerida a partir das exploraçóes acima, em que se constatou a diagonal da House I como resultado de duas posiçóes do deslocamento de quadrado tripartido, dois diagramas nine-square. A diagonal é marca do movimento, linha quebrada que indica o deslocamento de uma das divisóes do quadrado. Em outras palavras, a diagonal apresenta duas posiçóes da mesma linha durante o movimento de um quadrado: um quadrado é a posição real; e o outro, virtual, como a distinção entre sólido e diáfano vista acima.

Retomando o que Eisenman expóe, que a House I é deslocamento de quadrado na diagonal, podemos realizar uma terceira análise para explorar as diferenças entre a malha da House I e a da House $I I$, tendo como ponto de partida o deslocamento de um quadrado dividido em nove, nine-square, o qual será movimentado. Encontramos algumas confirmaçóes, marcaçôes, que ensejam essa divisão do nine-square. Os quadrados estáo deformados porque a sequência que estamos explorando é a inicial, sobre ela seriam aplicadas outras operaçôes. O deslocamento ocorre em dois eixos, portanto a divisão vertical não influencia neste momento. A diagonal é, então, a notação do deslocamento de um dos eixos da malha.

A partir desta malha, prosseguimos dando espessura a eixos, além de extrudá-los. Os eixos centrais são abertos em dois outros. Outras notaçóes do projeto, dimensôes, reentrâncias, corroboram estas operaçôes. É possível identificar que cada quadrado tem um sentido pela maior importância que é dada à operação orientada a este eixo e marcando o deslocamento com giro, visto na espiral da análise anterior. Realizando a mesma operação nos eixos "menores", encontramos outros elementos, menos marcados que os primeiros. Novamente, notaçóes do projeto atestam estes deslocamentos. Com estas operaçôes, temos os dois quadrados divididos em nove e as marcaçôes A-B-A-B-A nos dois sentidos.

A partir deste ponto, as operaçôes de intersecçôes destes dois quadrados e extrusão de volumes levam à forma final; não cabe, entretanto, prosseguir esta análise neste momento. A partir desta sequência de operaçóes, percebemos duas questóes sobre a malha. Primeiramente, a malha, o que remeteria mais diretamente à estrutura profunda, está deformada no resultado final. Há transformaçôes da malha, não há uma forte separação entre estrutura profunda e estrutura aparente 

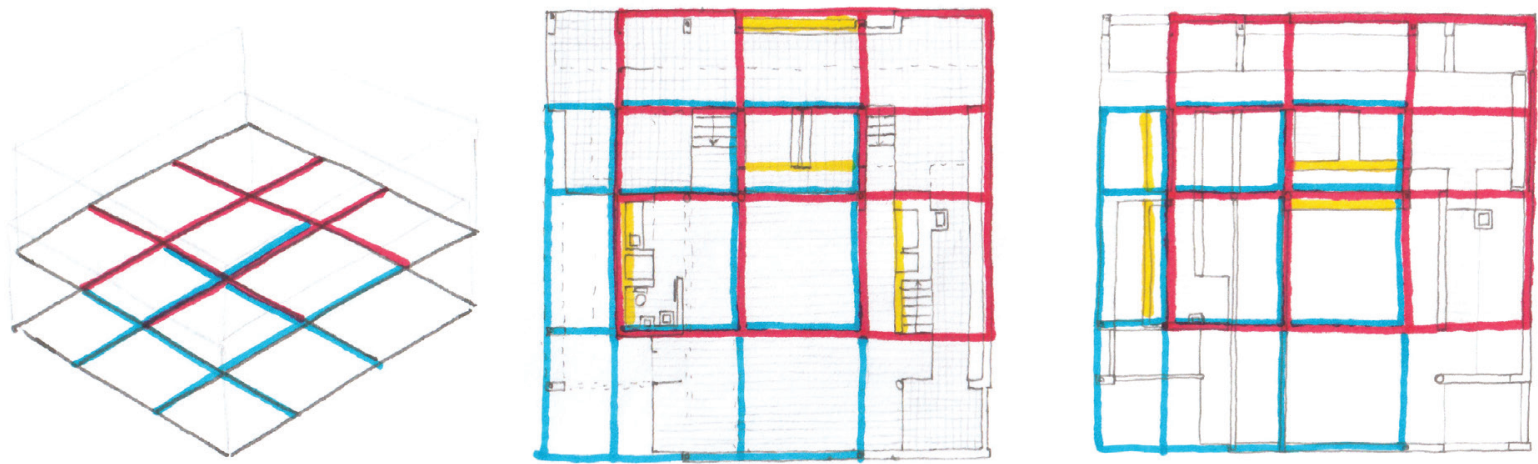

Figura 104 - House I, sobreposição de dois nine-square.

Fonte: Elaborada pelo autor.
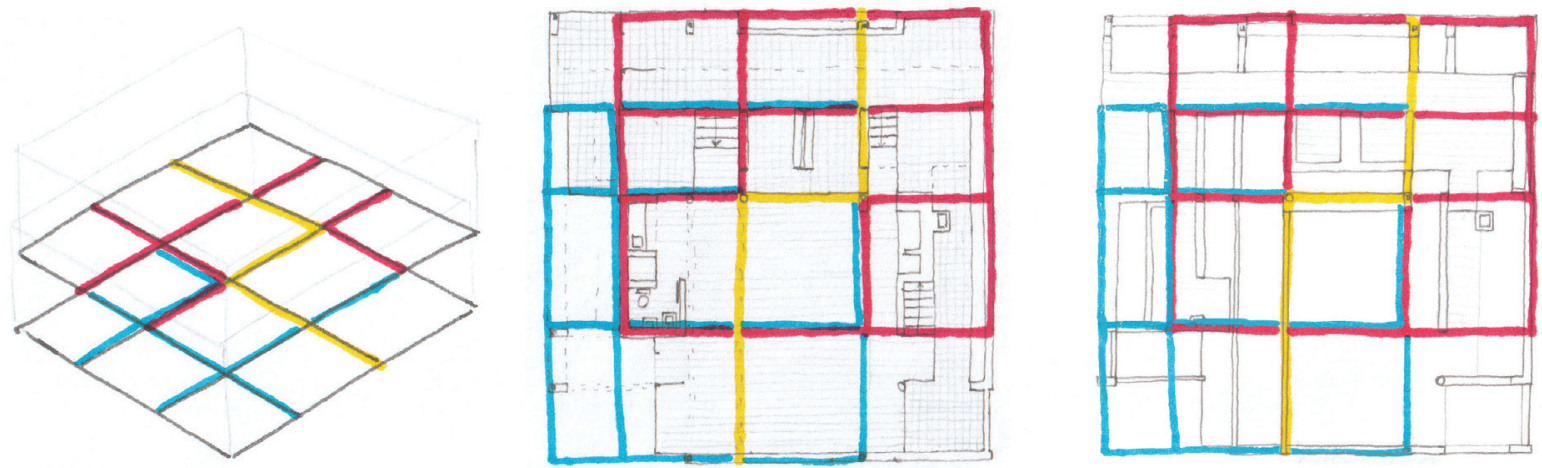

Figura 105 - Nine-square com a diagonal marcada. Fonte: Elaborada pelo autor.

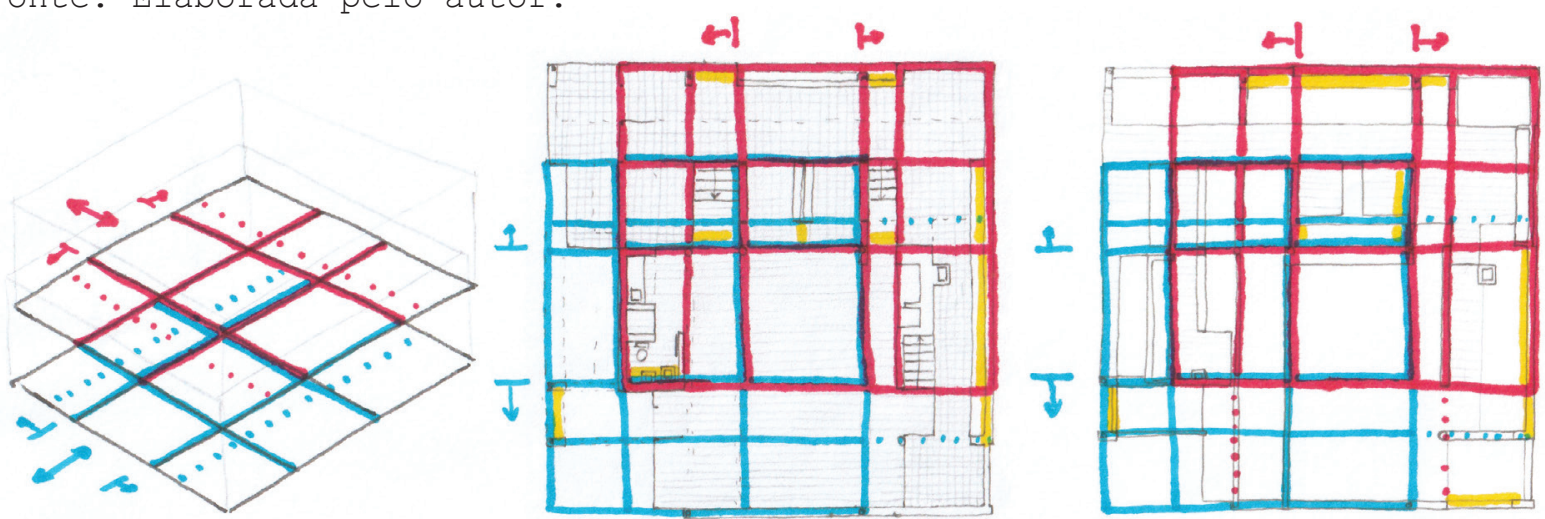

Figura 106 - Dois eixos no sentido principal de cada quadrado extrudado. Fonte: Elaborada pelo autor.
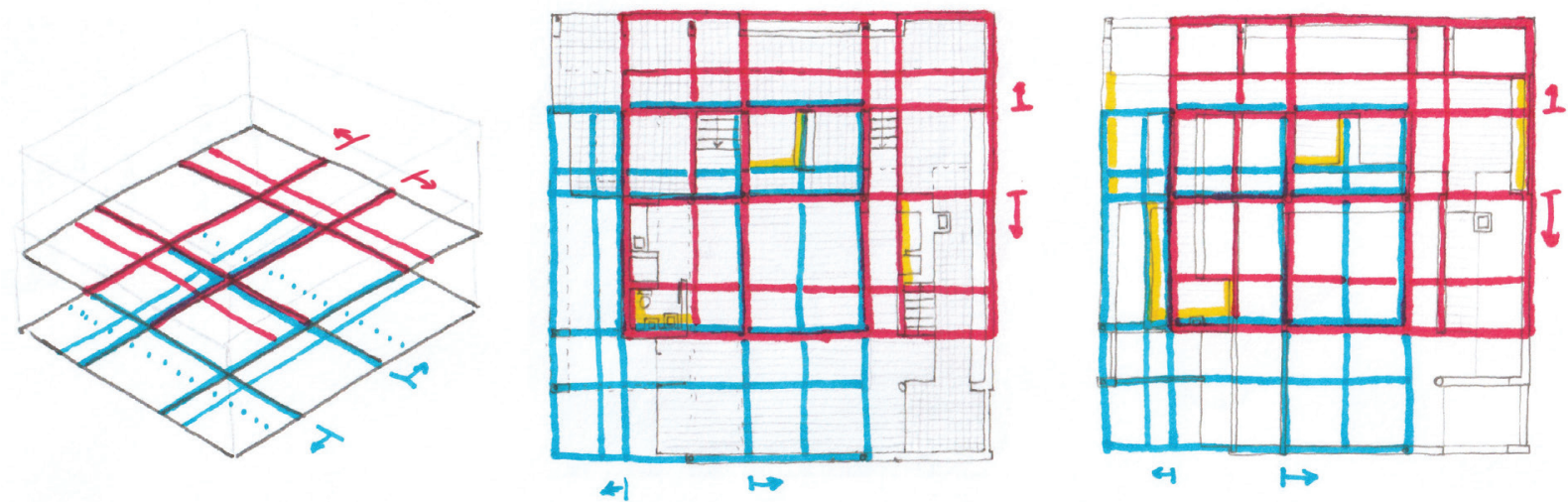

Figura 107 - Extrusão dos eixos menores de cada quadrado. Fonte: Elaborada pelo autor. 
como Eisenman defende na década de 1970 com a arquitetura conceitual e como aparece na House II; o que seriam a estrutura profunda e a aparente deformam como uma unidade. Em segundo lugar, o deslocamento diagonal ocorre em uma única malha. O passo de um módulo mantém os dois quadrados dentro de uma única malha de referência, e a forma do perímetro da casa é um quadrado dividido em dezesseis.

$\mathrm{Na}$ House II, ocorre deslocamento muito mais sutil entre dois quadrados, este não chega a um módulo da divisão em nove; há dois quadrados com repetição da malha. Cada uma fornece a posição de diferentes sistemas, pilares, planos, que marcam a posição não deformada da malha até o produto final. Marca importante deste pequeno deslocamento, desta duplicidade da malha, são as quinas onde aparece a defasagem do vértice dos dois quadrados. Diferença importante para a House I, na qual, sendo sobre uma malha e apegada à ideia de fechamento presente na Tese, patente principalmente nas análises de Le Corbusier, fecha um quadrado, todo movimento está contido em uma unidade. Mesmo que a quina da entrada sugira algo como a quina da House II, é diferente, além de ser uma condição única, não repete em outras quinas, não há a marcação de duas malhas, da repetição. Esta quina da entrada na House I marca apenas o deslocamento. Na segunda casa, todas as quinas atestam o deslocamento inicial, as duas malhas. $\mathrm{O}$ vértice vazio da primeira casa talvez tenha sido elemento de estudo, tal qual a diagonal, algo que fomentou exploraçáo de maneira mais incisiva na casa seguinte.

Esta mudança observada entre a House I e a House II apresenta importante passo na compreensão da autonomia da arquitetura por parte de Eisenman. É quando consolida sua posição de uma arquitetura como reflexo de seu processo e, principalmente, da autonomia do processo formal. A Tese é o primeiro momento, as bases formais da arquitetura. Eisenman está compreendendo autonomia pela forma, parte de exploraçôes como de Colin Rowe para afastar a arquitetura da história e da técnica, do simbólico e da função. Compreende a arquitetura imersa em um meio, dentro do qual seu papel, bem como o papel do arquiteto, é dar clareza ao ambiente pela adequada flexão da forma, pela adequação dos requisitos internos em relaçáo aos externos. Apesar do meio, e inserida nele, a arquitetura é autônoma pela lógica interna da forma. A malha opera como o regulador da forma, como referência para as distorçôes, a malha é elemento de conexão com a ordem total. Em segundo momento, da arquitetura conceitual, com auxílio de questóes da linguística, da estrutura profunda, corta o vínculo com o ambiente, liberando a arquitetura de determinaçóes pelo local ou função, tornando autônoma pela autorreferência. A ordem total é internalizada, o parâmetro da forma não é externo, mas é integrante do processo. Essa liberação ocorre a um preço, passo necessário: o 

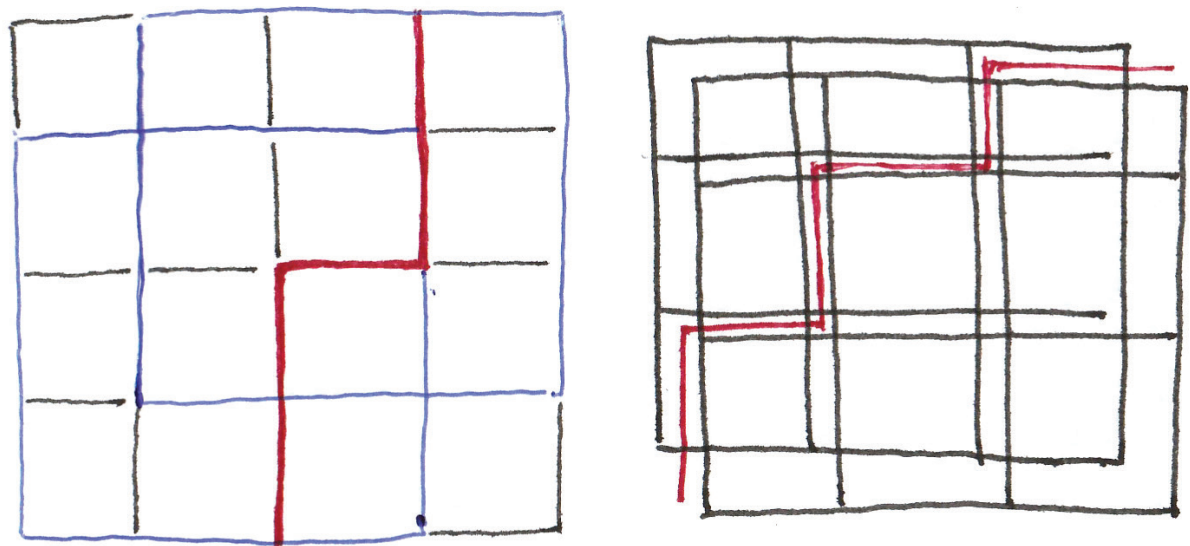

Figura 108 - Comparativo entre as grelhas da House I e da House II. Fonte: Elaborada pelo autor.
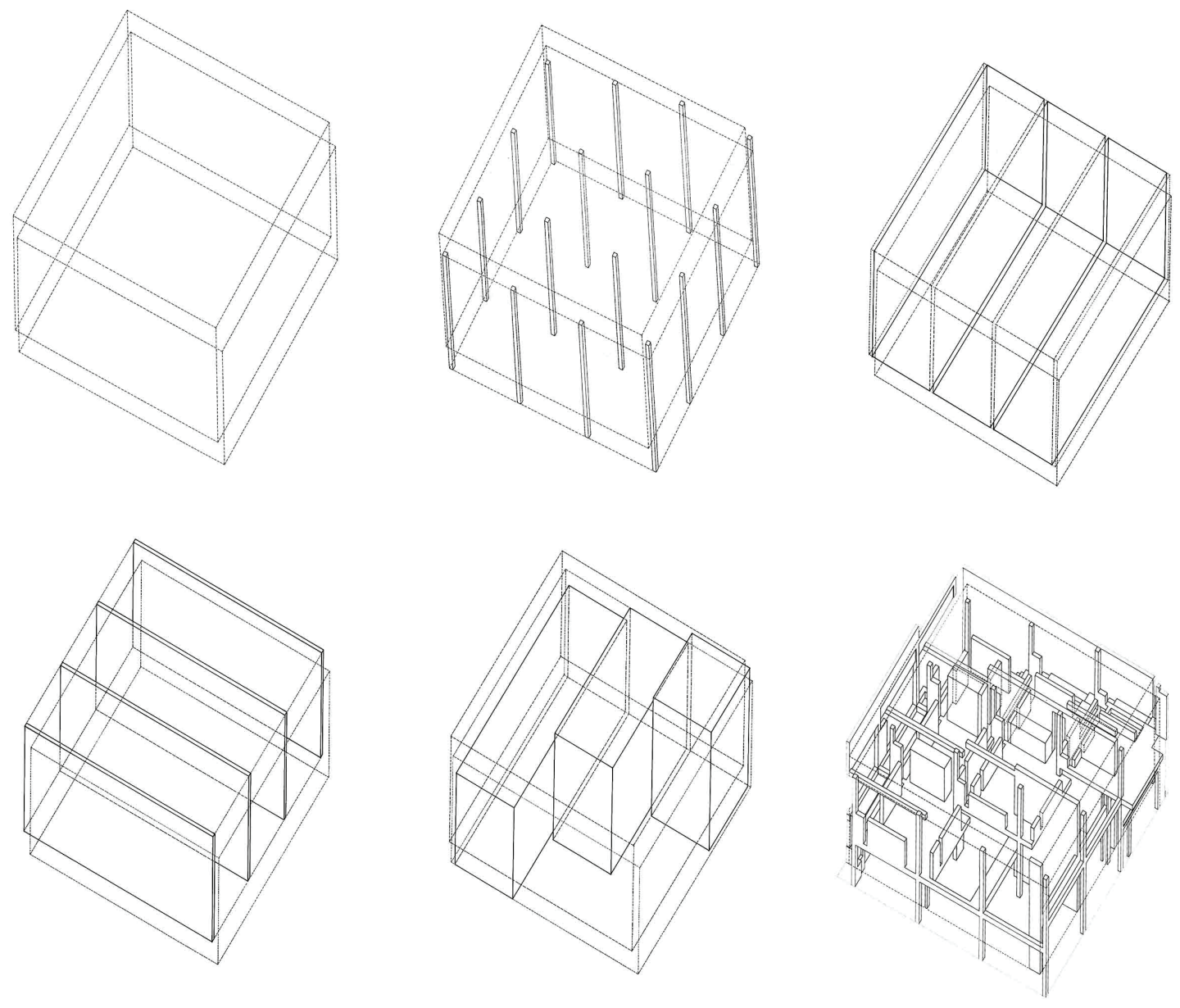

Figura 109 - Deslocamento entre os quadrados da House II.

Fonte: EISENMAN et al (1975, p.32-35). 
afastamento do meio e a compreensão da arquitetura como relação e não como objeto. Ao deslocar o semântico, a arquitetura torna-se sintaxe. Arquitetura como pura relação, sintaxe como contexto, a malha deixa de ser regulador único, integrante de uma ordem maior que o projeto, e torna-se uma ferramenta reguladora, pode ser repetida, outrossim, diferentes elementos são flexionados pelas diferentes malhas.

Marca importante deste processo é a ausência, na House II, da influência de uma força externa, como o vetor do acesso da House I, principal elemento de deformação e de não haver simetria das flexóes da forma. Além de afastar-se do meio, isso remove necessidade em relação ao desenho representar um edifício. Uma planta, ou uma isométrica, adquire autonomia como produto, ou o edifício se faz maquete, como Otilia Arantes (1993) e Cynthia Davidson (2006c) apontam da House II. A autonomia da forma - as transformaçôes da forma que ocorrem independentemente do meio, do arquiteto ou do usuário - é o que define a arquitetura neste momento. Sua fase das Transformações, operaçóes positivas que formam o projeto, torna o processo produto. Cada casa é como um ponto arbitrariamente congelado de infinitos possíveis desdobramentos de processo formal. Arquiteto é o operador de um mecanismo, um processo externo e independente dele. $\mathrm{O}$ processo mais do que um objeto é uma narrativa.

Estas análises da House I permitiram que percebêssemos importante diferença entre a Tese de Eisenman, as bases formais da arquitetura, e sua arquitetura conceitual. Inicialmente, há uma relação com o meio, um diálogo da forma com questóes externas, o que é cortado posteriormente. Porém, há uma continuidade, as ferramentas para lidar com a forma, os modos de leitura e as transformaçóes iniciam na Tese e prosseguem adiante na carreira do arquiteto. Quando Eisenman passa das exploraçóes de sua Tese, as bases formais da arquitetura, para sua arquitetura conceitual ele altera seu embasamento conceitual, a estrutura de seu pensamento, mas as ferramentas, o método de explorar a forma permanece. Marca da continuidade das ferramentas é que encontramos em ambas as análises elaboradas da House I características presentes nos projetos dos quatro arquitetos que Eisenman estuda em sua Tese. Pudemos observar então o modo como a House I insere-se nas exploraçóes do arquiteto como um momento de inflexão - este projeto pode ser lido tanto dentro das premissas das bases formais quanto dos conceitos da arquitetura conceitual. As análises revelaram características que sugerem que a leitura de seu próprio processo de produção permite a Eisenman percursos que explora em outros projetos, temos como principal exemplo a diagonal da House I, a qual foi rediscutida na House II. Foi possível identificar que a possibilidade desta condição de ponto de inflexão é devida a permanências entre os dois momentos do pensamento de Eisenman; neste 
ponto, pudemos identificar como principal continuidade os instrumentos de leitura da forma. Em ambas as fases, o arquiteto disseca o espaço em volumes positivos e negativos que se justapóem ou interpenetram.

Importante deste caminho percorrido por Eisenman é a relevância da proposta que assume no fim de sua Tese para formar teoria aberta. Pouco a pouco, identifica pontos de fechamento e, ao apreendê-los, os desestabiliza em nome da ambiguidade, da potencialidade. Paulatinamente, o processo de desvincular a forma de sentidos definidos reconhece a irredutibilidade do objeto ao discurso sobre o objeto. Os pontos que identificamos sugeridos na House I e exponenciados na House II seguem esta premissa: abstrair, desestabilizar o sentido em nome da potencialidade da forma. A diferença na condição da malha entre estes dois projetos mostra processo por meio do qual este elemento torna-se menos restritivo. Encontramos, então, na House I uma etapa desta busca de Eisenman por liberar as formas de pré-definiçôes em favor de que elas tenham maior potencial de significado:

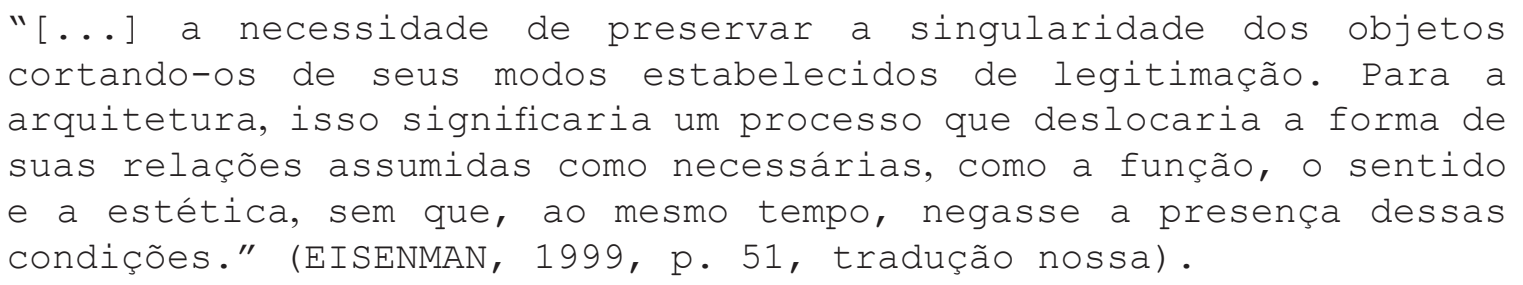


足

U

[I]

U

4

r

$[1]$

$\triangle$

$\mapsto$

U

Z

$\checkmark$ 


\subsection{House I-Da Tese à Série}

A partir do acima analisado da House I, podemos observar que tanto a Tese de Eisenman, The Formal Basis of Modern Architecture (EISENMAN, 2006c), quanto seu primeiro projeto, a House I, são marcos importantes. Estas duas expressóes traçam caminhos que o arquiteto desenvolverá ao longo de sua carreira. Destacamos sua teoria aberta, a procura por não estabilizar sentido por meio da ambiguidade e a forma de analisar arquitetura como volumes negativos ou positivos, justapostos ou interpenetrados. Além disso, analisamos a conexão e diferenças entre a House I e a House II, a relação da malha e do vetor externo, movimento que é substituído pela repetição da malha. A partir disto, podemos explorar a ideia de que a série de casas que o arquiteto desenvolve no início de sua carreira, da House I à House X, consiste em um processo formal que parte da House I. Por esta perspectiva, a House I atua como um nexo que conjuga elementos de sua Tese e de Terragni para seus desenvolvimentos seguintes - nesta fase denominada Transformações, não são operaçóes quaisquer da forma, mas desenvolvimentos diferentes de um mesmo cubo oriundo das duas fontes citadas. O mesmo processo ocorrido entre a House I e a House II ocorre entre outros projetos desta série de casas.

Podemos traçar esta relação a partir da diagonal, encontrada na análise da Casa del Fascio presente na Tese (EISENMAN, 2006c), no oblíquo da Casa Giuliani Frigerio (EISENMAN, 1971) e em quase todas as casas que Eisenman desenvolve nesta fase. Da House I à House II, há substituição do vetor pela malha, mudança da apresentação de uma força para a apresentação de estados, relaçóes. Analisamos o vetor na House I ao vermos a diagonal como movimento, a compressão ortogonal e a espiral desenvolvida do acesso ao primeiro pavimento, esta última remetendo ao giro. Movimento como posição do observador do mesmo tipo que Eisenman analisa da Casa Giuliani Frigerio, a localização é que permite o oblíquo. Na análise da Casa del Fascio, aparece a noção de um centro vazio, na House I essa noção adquire clareza com o movimento centrífugo da espiral.

Eisenman em seus textos Cardboard Architecture (EISENMAN, 1973a) e House VI (EISENMAN, 1977) reforça a concepção de que as quatro casas anteriores formam um "conjunto distinto", com isto, as flexôes que ocorrem na forma da House I fornecem situações abstratas mais facilmente relacionadas até a House $I V$. Podemos ler que, em cada uma dessas primeiras casas, desenvolve uma hipótese que surge na House I: House II desenvolve a diagonal; House III, o giro que encontramos no movimento espiral com a utilização de grelha não ortogonal; e a House $I V$, a relaçáo entre o centro e a periferia como desenvolvimento do vazio que surge no centro e da ideia 
de movimento, das transformaçôes ocorrendo ao longo do tempo, como observamos na série de compressóes dos planos frontais da House I ou o deslocamento do cubo - situaçóes que vimos aparecerem na House I imbricadas à forma, a fim de transmitir a ideia de uma ordem total. Nestes outros projetos, desenvolverá essas questôes conceituais em paralelo, por meio da ideia de estrutura profunda e estrutura aparente. Estas características encontradas na House I percorrem processo típico de Eisenman: um conceito inicialmente visto, utilizado em uma situação posteriormente identificada como limitante, é retomado em momento adiante de forma menos constrita.

Acima pudemos discutir a diagonal da House I em relação à da House II conforme esta ótica. $\mathrm{Na}$ House II, Eisenman também aprofunda a dialética entre real-virtual. Como a abstração, o distanciamento do sentido, esta dialética será aprofundada por Eisenman ao longo de seus projetos. Se na House I a dialética real-virtual aparece principalmente a partir de volumes positivos e negativos, elementos que marcam o espaço pela ausência de matéria, na House II sugerirá como virtual a marcação de possíveis elementos (EISENMAN et al., 1975, p. 25-26). A possível posição de um elemento enseja a ideia de tempo, de processo. Podemos associar este tempo do deslocamento com característica que encontramos na Tese: ao analisar a Casa del Fascio, considera a divisão tripartida como uma narrativa, com começo, meio e fim - um processo temporal em uma forma final, como a pretensão do cubismo, que influencia Eisenman por meio de Rowe e Slutzky. Esta ideia de diferentes etapas de um processo temporal está presente na House I de forma incipiente na compressão dos planos a partir do eixo frontal, aparecem sobrepostas diferentes etapas de uma ação no tempo, e na espiral, um movimento cujos reflexos estão "congelados" nas marcas de seus vetores. Na House II, o virtual apresenta possíveis posiçóes da forma resultado de um processo, a sugestão que um elemento, seja sólido, seja vazio, poderia estar em outro local. Narrativa não só de vetores, mas de transformaçóes da forma.

A conexão entre a House III e a House I aparece não só pelo giro, mas também pela diagonal. Observando desenhos do arquiteto deste projeto, antes de introduzir a malha rotacionada 45 graus, apresenta o mesmo método de agitação do cubo inicial pelo ligeiro deslocamento diagonal, pela repetição da malha análoga à da House II. Como na House II, a quina apresenta de forma clara a referência aos dois quadrados originais deslocados não deformados por meio das duas malhas que não se tocam. Percebemos que a House III depende, em certo sentido, do maior grau de liberdade adquirido pela malha no projeto anterior. Neste projeto, é sobreposta uma malha a mais, a qual é rotacionada; processo impossível na House I - vimos que neste projeto todo giro é conformado à única malha ortogonal. Além disso, o giro de 45 graus difere do deslocamento que vimos na terceira análise 140 
da House I. Nesta, constrito a uma malha de referência, a rotação ocorre em incremento ortogonal, 90 graus. $\mathrm{Na}$ House III, com a autonomia da malha, o giro forma outras relaçóes. A repetição da malha, por exemplo, permite que ela gire suficientemente para ser alinhada com a diagonal. Neste sentido, considerando que este projeto é desenvolvido próximo ao período que Eisenman escreve o texto From Object to Relationship II, essa relação da diagonal ganha outro sentido: além de procurar a dialética massa-superfície, vista na Tese, estuda a dialética frontal-oblíquo encontrada neste momento na Casa Giuliano Frigerio, de Terragni. De um mesmo ponto de vista, a apreensão é do plano e da quina. O processo de transformação da forma é operado a partir das interferências desta sobreposição. A malha rotacionada remete à ideia de tempo e movimento; ela expressa o giro sugerido na espiral da House I, mas a partir de uma condição sintática da estrutura profunda. Portanto, além da diagonal, Eisenman acrescenta o movimento e giro sem a influência do vetor de entrada, de forma abstrata, arbitrária.

$\mathrm{Na}$ House IV, não encontramos o deslocamento diagonal ou a sobreposição de malhas, mas há movimento pela divisão do cubo inicial a partir de seu centro. Não ter a diagonal não invalida as relaçôes aqui exploradas, isso revela o caráter não linear das casas de Eisenman, como o arquiteto explora diferentes questôes. $\mathrm{O}$ aqui proposto é apenas que as questôes que explora se originam da House I. Diferentemente da divisão inicial em nove, a House IV parte de cruz, de divisão em dois por dois, cujos planos ganham espessura chegando ao três por três. Há uma relação tênue entre esta cruz e a divisão do volume rompido no centro da House I, como vimos na segunda análise. Ao mesmo tempo que essa operação de divisão em quatro coloca um passo antes da divisão em nove, ela permite discutir relação centro/periferia. A cruz marca o centro a partir do qual transformaçóes paralelas de planos e volumes são compostas em forma final concentrada na periferia, incluindo elementos que "excedem" o cubo original. A noção de um centro que se esvazia remete ao vazio presente no centro da House I e da House II e que percorrerá diferentes projetos ao longo da carreira do arquiteto. Quanto à relevância do vazio, Cynthia Davidson, em seu texto The Absence of Presence; or, the Void (DAVIDSON, 2006c), faz uma exploração rápida de projetos de Eisenman sobre vazio com sentido conceitual, na qual parte da House II, House XIa, Cannaregio, IBA Housing, Choral Works, Aronoff Center for Design and Art, Nunotani Headquarters para culminar na Igreja do Ano 2000, cuja nave, elemento importante do projeto de uma igreja, é um vazio delimitado por duas dobras que compóem as naves laterais. O movimento à periferia remete a movimento centrífugo. Como vimos, a espiral da House I resulta em movimento centrífugo, agora Eisenman o faz sem a espiral.

A ideia de divisão em três remete diretamente à análise que Eisenman faz da Casa del Fascio 

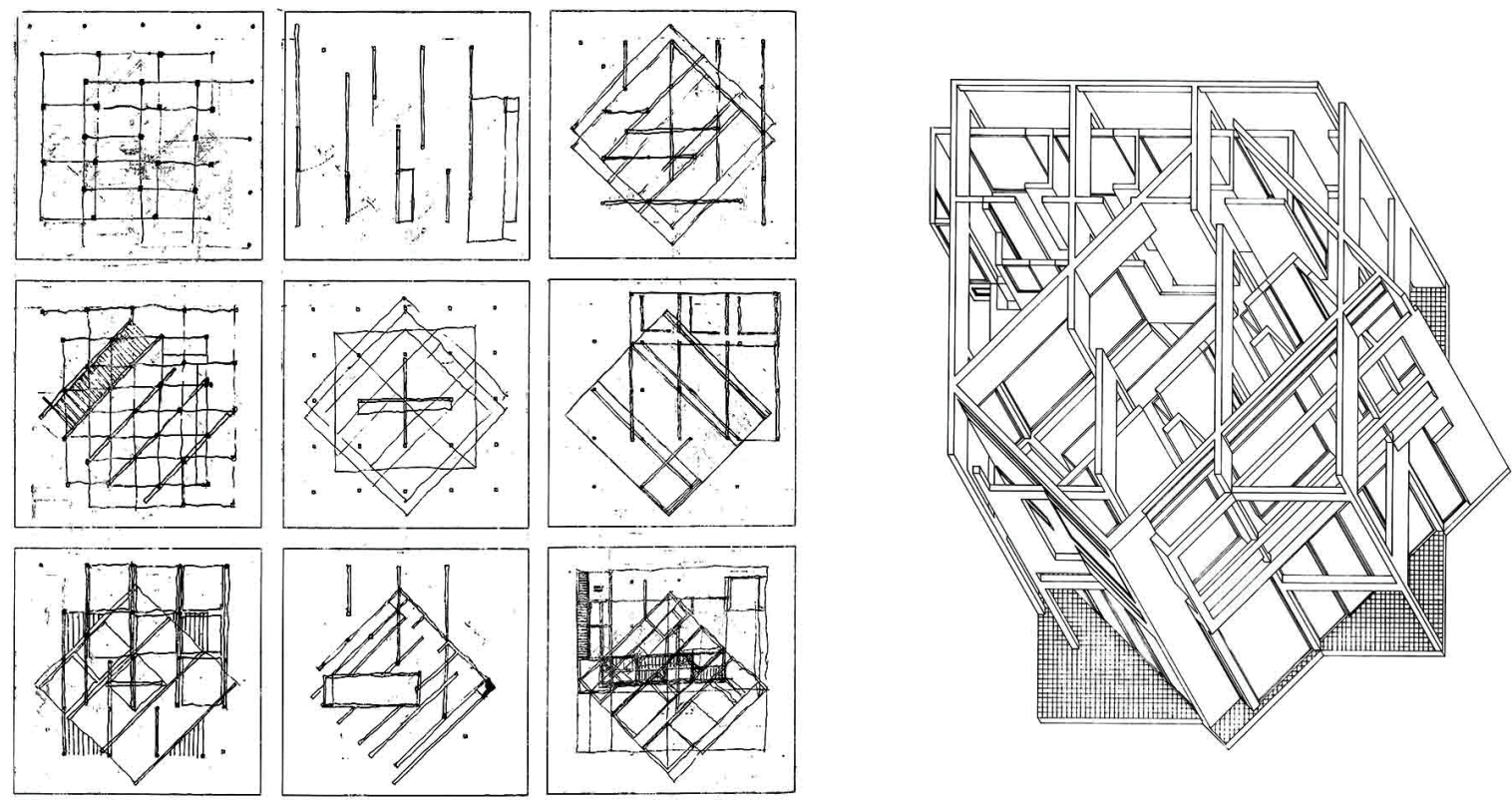

Figura 110 - Desenhos conceituais e perspectiva isométrica da House III. Fonte: Site Eisenman Architects.

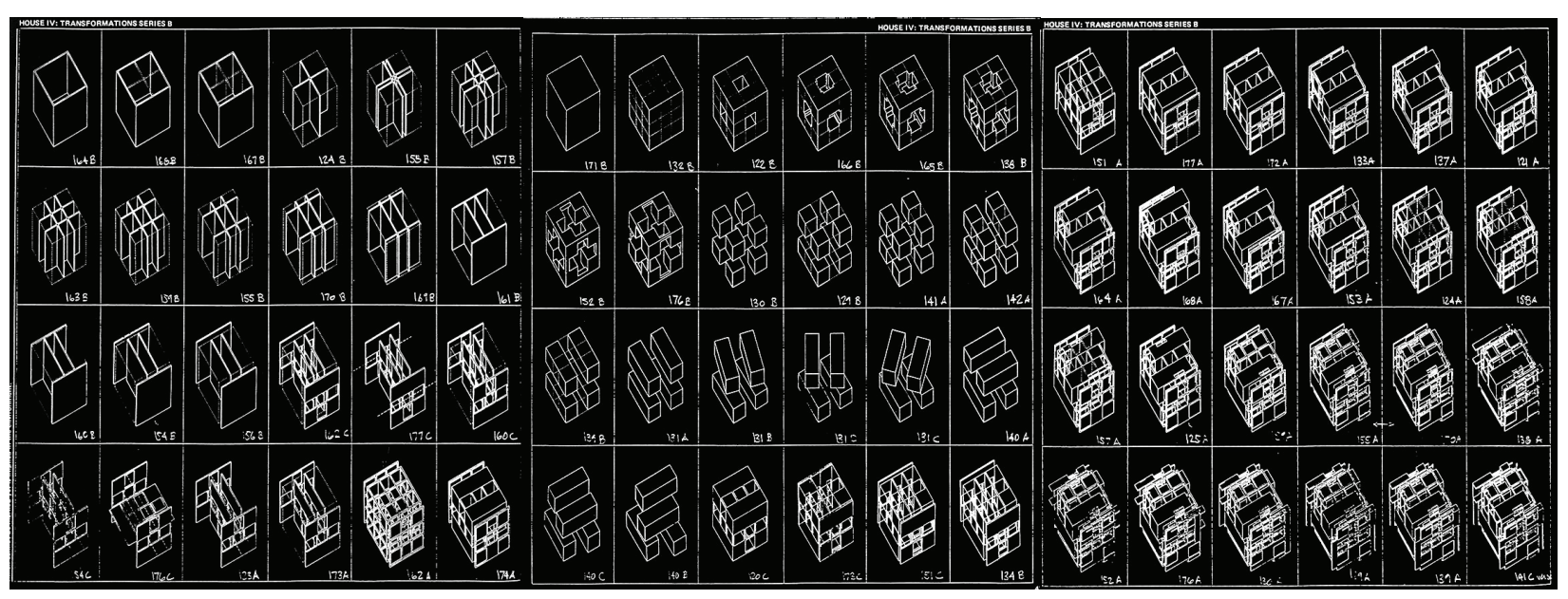

Figura 111 - Desenhos conceituais da House IV.

Fonte: Site Eisenman Architects. 
e à associação que faz entre o três e a narrativa, particularmente pela ideia de: começo, meio e fim. A narrativa deixa de ser na forma para ser no processo da forma, a sequência cinemática da formação da casa. Não é a narrativa da forma A1-B1-A1-B1-A1 progredindo a A2-B2-A2-B2-A2, mas das etapas A1, A2, A3, A... e B1, B2, B3, B... e da sobreposiçáo de A e B e C. O que vimos até então como uma característica secundária nesta casa ganha destaque na discussão da arquitetura como processo de si mesma. Eisenman apresenta por diferentes notaçôes sucessivas etapas de sua elaboração formal, inclusive uma das formas que expôs esse projeto foi com um filme, sequência dos quadros das transformaçóes. O que na House I era a incipiente compressão dos planos, apresentando diferentes etapas deste movimento, torna-se a força motriz do projeto, passa a ser o processo de sua própria elaboração. Exploração do real e virtual, a forma final da House IV apresenta diferentes etapas de sua formulação.

A House VI parte da mesma divisão inicial que a House IV. Podemos considerar essa divisão "passo para trás" no qual Eisenman coloca uma divisão antes da divisão em três por três, também como um sinal de rompimento com o moderno. Além do quadrado dividido em nove remeter diretamente à sua análise da Casa del Fascio, o diagrama nine-square, o problema dos nove quadrados, está diretamente ligado ao modernismo. ${ }^{1}$ Considerando a separação que Eisenman faz entre as quatro primeiras casas e as seguintes, pode ser já um anúncio de sua mudança entre continuidade ao moderno para procurar superar o moderno. Mudança que se consolidará apenas na fase das Decomposiçôes, nos textos Post-Functionalism (EISENMAN, 2006b) e The End of the Classical: the End of the Beginning, the End of the End (EISENMAN, 1984).

Diferentemente da House IV, na House VI essa divisão inicial aparece deslocada na diagonal. Em desenho publicado pelo arquiteto, é possível identificar um quadrado maior dividido em quatro e por traços menores em nove, com um dos quadrados menores, como resultado da divisão inicial em quatro, também dividido em quatro e em nove. Este quadrado menor que dá o início dos eixos ortogonais do projeto, suas duas divisôes, forma um centro deslocado na diagonal. Repetição da malha dentro da malha, Eisenman encontra outra forma de fazer a diagonal, não pelo deslocamento de dois quadrados ou pela repetição da malha, mas pela repetição da operação.

Nessa segunda etapa, a divisão em quatro é levada adiante nas House VIII e House X, projetos nos quais a divisão inicial do cubo em quatro o fragmenta. Na House $X$ Eisenman potencializa a noção de centro como vazio tornando o núcleo do projeto um vazio entre os cubos. Dividir o cubo

1 Sobre a relação do nine-square com o modernismo e com Hejduk, tanto em seus projetos quanto em sua atuação pedagógica, ver o livro Architecture's Desire, de Michael Hays (2009), e a introdução ao compêndio de texto de Eisenman Written into the Void, escrita por Jeffrey Kipnis (2007). 

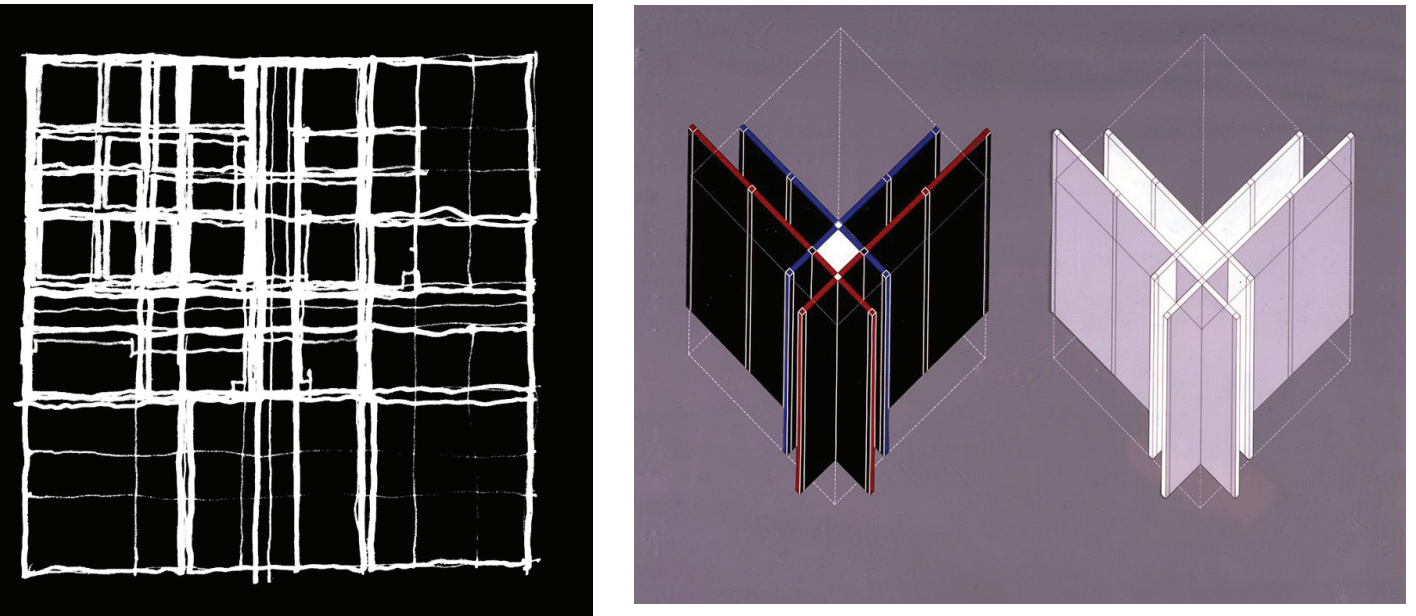

Figura 112 - Imagens conceituais da House VI. Fonte: Site Eisenman Architects.
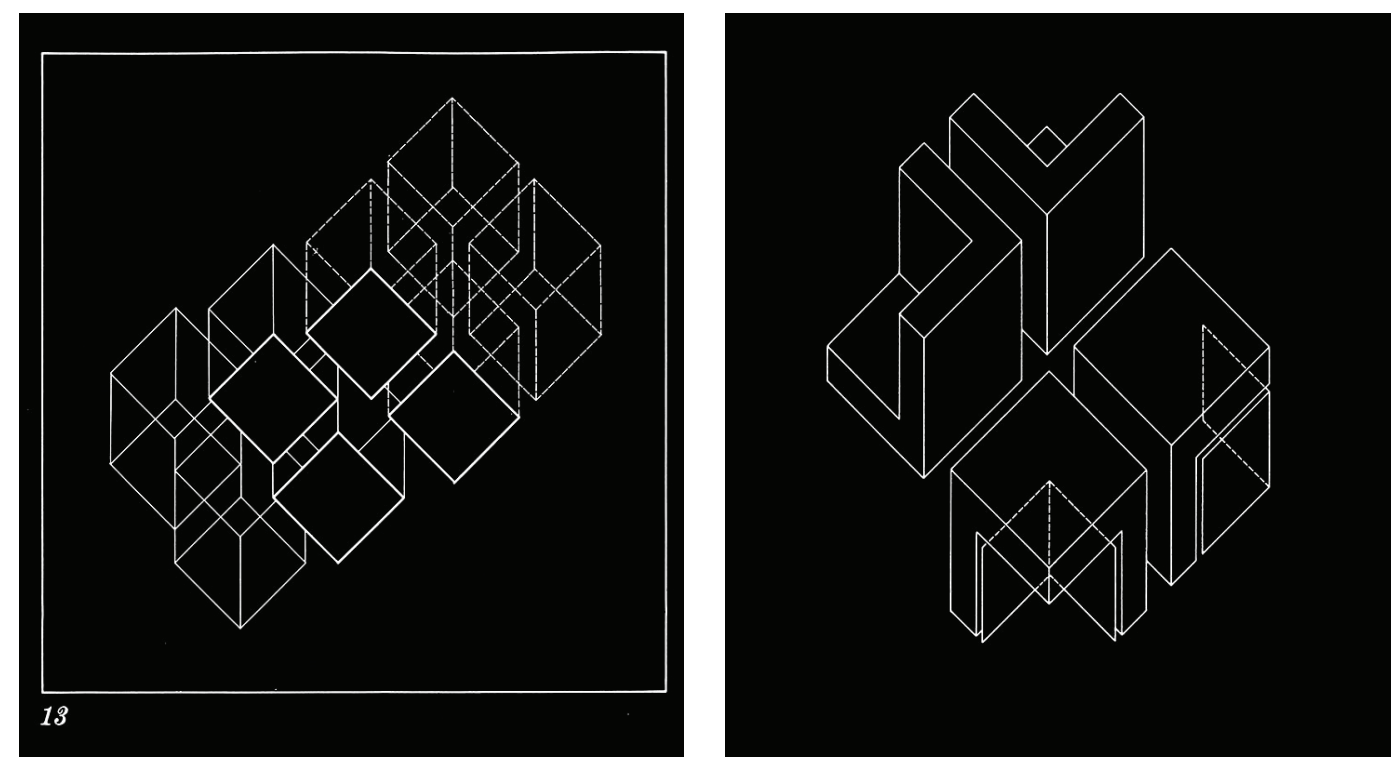

Figura 113 - Imagens conceituais da House X. Fonte: Site Eisenman Architects.

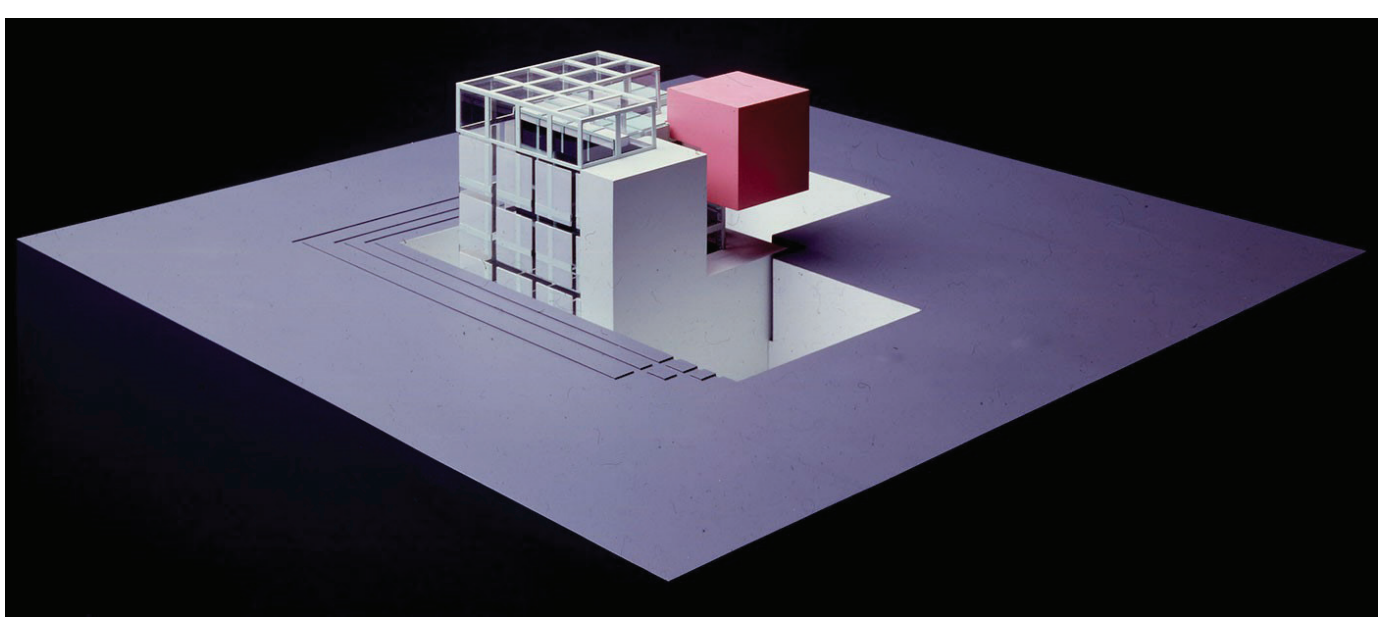

Figura 114 - Maquete Fin D’Ou T Hou S. Fonte: Site Eisenman Architects. 
inicial em outros quatro é repetição da malha em outra potência, repete o volume do cubo. Na House $X$, reencontramos a diagonal, neste projeto Eisenman amplia o deslocamento em dois eixos para três eixos. A forma "El", um cubo com cubo subtraído, é resultado de um cubo deslocado nas três dimensôes, em diagonal, em relação a outro cubo. Esta subtração traz o movimento e a concepção do real e do virtual, de duas posiçóes de um cubo, de onde ele está e onde possivelmente estaria.

Por esta rápida exploração, percebemos que procedimentos incipientes na Tese e desenvolvidos na House I, como o deslocamento diagonal como mobilização da forma, a relação entre centro e vazio e o movimento atrelado à dialética real-virtual (que adquire diferentes nomes: genérico/específico, estrutura profunda/aparente), atingem amadurecimento na House X com a forma "El". Essa forma traz a dialética, a ambiguidade que Eisenman identifica primeiro na relação massa/superfície, carrega a instabilidade de sentido, o deslizar de um polo a outro. Como Hays apresenta: o cubo "El" torna-se uma forma básica, recusa a ser quebrado nos projetos posteriores, nas decomposiçóes. Uma forma que não se quebra, mas que também está à espera de ser completa: “[...] a compressão de uma postura ideológica complexa em uma singularidade.” (HAYS, 2009, p. 73, tradução nossa).

A diagonal, o efeito do tempo na forma, e a ausência de sentido em favor de relaçóes de sintaxe são canalizadas da Tese pela House I, culminando, no fim das Transformações, na forma "El” na House X. A diagonal, inicialmente resultado de condiçóes externas, que flexiona a forma, distorce a malha, torna-se o resultado, o reflexo de repetições e sobreposiçóes de malhas, e, por fim, objeto, a forma "El". Reitera esse conjunto de casas como uma série, da House I à House X, as quais formam conjunto no qual o arquiteto pesquisa sobre operaçóes da forma que culminam em elementos que subsidiarão composiçôes de outra potencialidade. Para além das transformaçóes que partem de um cubo, projetos como o da House XIa e da Casa Guardiola partem da forma "El" nos quais ela é sobreposta, repetida, escalonada, bem como o da Fin D’Ou T Hou S, cuja forma é basicamente a subtração do cubo pequeno formando o "El".

\subsection{House I-Da Série à Carreira}

A forma "El” e o projeto da House X marcam o fim da fase das Transformações, é o ponto máximo dessa tentativa do arquiteto de construir a forma a partir de processos lógicos e a consolidação das pesquisas iniciadas na Tese. Consequência da autorreferência deste processo, como vimos acima, o projeto não tem um único ponto de entrada, não forma uma leitura pautada a partir de um ponto externo como nas análises da Tese. Diferentemente destas análises de caráter dedutivo, ao 
tentarmos aproximação ao projeto da House I pela descrição de Eisenman, o processo é circular: do fim da diagonal retomamos ao começo. O reconhecimento deste processo leva à fase seguinte, da Decomposição - Eisenman não almejará compor o objeto, mas escrutiná-lo; como Kipinis (1998) e Sophia Teles (1993) salientam, não mais operaçôes lógicas, mas analógicas. Em seu livro House X, Eisenman aponta que uma diferença importante entre as transformações e as decomposiçóes é: as primeiras são processos lineares, partem da formação de um objeto, a "um fim previsível”, enquanto as seguintes partem de "um fim em busca de seus limites inerentes"; não procura compreender as regras da forma, mas o "objeto e a objetualidade em geral" (EISENMAN, 1983, p. 38, tradução nossa). Neste sentido, o processo linear de transformação da forma a partir de suas próprias regras, arquitetura como processo de si, autorreferente, é o que vimos eclodir da autonomização do processo entre a House I e a House II e que leva à House X. Ao levar esse processo iniciado às últimas consequências, Eisenman desenvolve um sofisticado repertório de trabalho com a forma. ${ }^{2}$ Como vimos, extrapola do vetor, resumido na diagonal, à malha e à repetição desta. A repetição da malha, a sobreposiçáo destas, como, por exemplo, na House III, será ferramenta que carrega na nova fase.

Essa divisão da primeira à segunda fase é marco importante - no livro Diagram Diaries (EISENMAN, 1999), ao tentar articular sua carreira pelo uso do diagrama, fica evidente uma mudança que marca incisivamente o percurso: de diagramas de interioridade passa a diagramas de exterioridade. Nas Decomposições ou Cidades das Escavaçóes Artificiais, Eisenman retoma elementos deixados em segundo plano desde sua Tese, neste caso, o meio; este ganha outro caráter diferentemente do absoluto impessoal da ordem total presente na Tese, o meio é uma construção. $\mathrm{Na}$ Tese, discutia fatores externos e internos de determinação da forma. Porém, vimos que, no processo das casas, elimina o externo e potencializa o interno, em processo de dúvida sistemática que caminha em nome de condiçóes cada vez menos determinadas: o que era a forma genérica da ordem total, uma camada, tornam-se duas, a estrutura profunda e a aparente, e, por fim, pluralizam-se em várias estruturas profundas. Em certo sentido, nas decomposições traz esse raciocínio ao que é externo, o meio é uma infinidade de camadas.

Eisenman denomina "escavação artificial", pois depende de quem, como e quando escava. O meio não é impessoal, Eisenman reconhece que seleciona as referências; frente ao objeto, a visada do arquiteto apresenta uma narrativa parcial, um possível que este objeto é capaz de apresentar narrativa que não é única nem totalizante, como acima citado, "é necessário preservar a singularidade

2 Diferentes autores citam esta característica: Montaner (2001, p. 168-171), Moneo (2008, p.174) e Jencks (1989, p.262). 
do objeto.”. É por meio da abstração e da repetição que busca deslocar os sentidos externamente determinados, em favor de preservar o objeto enquanto tal, não uma representação opaca posta sobre ele. Este processo de Eisenman permite a apreensão das relaçóes, dos sentidos deslizantes, das flexóes das estruturas formais, abre caminho para o observador compreender as estruturas que subjazem à forma; estruturas mediadas, não se apresentam desnudas, são intersecção entre o objeto, o arquiteto e o usuário. Importante que procura apresentar relaçóes ao invés de representá-las. Se esta condição de autonomia do objeto é inerente a qualquer arquitetura, a diferença é que Eisenman reconhece este processo, denominando-o "escavação artificial” (EISENMAN, 1999, p. 51), como Kipnis (1998) diz: uma arquitetura do possível. Uma arquitetura cuja recusa a um sentido estável, vinculada à indecibilidade, abre-se ao evento:

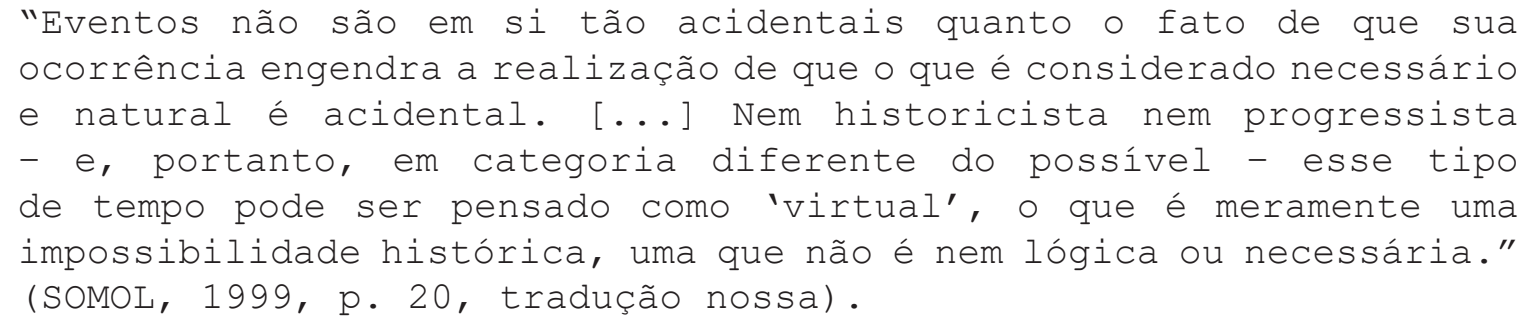

Essa guinada operada no Cannaregio nos permitirá ver crítica a dois conceitos encontrados como importantes no desenvolvimento de Eisenman: a grelha e os binômios. A ideia de ambiente total da Tese é associada ao espaço cartesiano, uma referência genérica e isomórfica, qualquer ponto da grelha é indistinto de outro ponto. Como vimos, em sua Tese Eisenman discute o ambiente total como aquilo que se apresenta ao projeto e a esse deve dar clareza. No desenvolvimento das casas, o arquiteto dialoga diretamente com o espaço genérico, como vimos opera sobre a malha e repetiçóes dela; mesmo que a malha deixe de ser única, ainda é um espaço abstrato, desterrado. No Cannaregio, ele volta ao ambiente existente de forma distinta - diferentemente do ambiente total, que pode ser apreendido por uma forma, o espaço que desenvolve o projeto é sobreposição de diferentes espaços: a Veneza atual, a Veneza medieval, a Veneza do projeto que Le Corbusier faz para a regiáo e o espaço da House XIa. Espaço do projeto é distante do espaço uniforme cartesiano, passa a ser um espaço em relação a diferentes pontos de vista, a história. As malhas não são repetidas a partir de um movimento inicial genérico ou de um espaço neutro, mas são oriundas de diferentes elementos, elas são uma parte e uma tradução desses elementos.

Projeto para o Cannaregio é marca de sua discussão acerca da disciplina, não só traz projeto moderno, mas um projeto seu, a House XIa. Repetida em três diferentes escalas sobre a malha oriunda do projeto de Le Corbusier, rompe a noção de habitar ao vir como maquete, como casa e 
como monumento. Eisenman passa a reconhecer que, mesmo fazendo arquitetura que não respeita a escala do homem, isto é, não antropocêntrica, é na relação com o sujeito que ela se forma. Noção como esboçada no texto Dall'Oggetto alla Relazionalità (EISENMAN, 1970a), de que as relaçóes surgem a partir do sujeito que apreende a forma e as elabora, retorna. A repetição é importante para o deslocamento de relaçóes pré-determindas, ela opera nos elementos, nas notaçóes; como vimos, é uma ferramenta importante do scaling de Eisenman: um elemento é deslocado e justaposto em novo contexto que guarda relação parcial com o original - a House XIa é repetida em novo contexto, deixa de ser a habitação original e passa a ser ruína em Veneza.

As três repetiçôes do scaling apresentam questionamento aos binômios, importantes até então para a ambiguidade; esta foi ferramenta usada para não fixar sentido, ao deslizar entre dois polos com características opostas - massa/superfície, frontal/oblíquo. Agora, não fixa sentido pela repetição do mesmo de maneira a diferir, a deslizar, pelas proximidades a outros elementos, ao contexto, por analogia. Serem três repetiçôes é relevante, número mínimo para evitar o binômio, para não se enquadrar na categorização de A e não A do terceiro excluído.

Esse rápido percurso ao Cannaregio reforça a importância da House I como nexo das questóes iniciais de Eisenman, como ponto de partida que se expande durante a série de casas e tem fechamento na House $X$, início de formatação de instrumental de projeto. Permite-nos também destacar a importância da Tese de Eisenman, pois encontramos na House I questóes que permanecem, a teoria aberta, a ambiguidade e a forma de compreender o espaço por volumes, além de questóes que ganham presença posteriormente - o meio, por exemplo, é momentaneamente deslocado para voltar em situação mais madura do pensamento de Eisenman.

Podemos relacionar este percurso da série de casas, do vetor à malha, e, por fim, a repetição e o modo como estes elementos adquirem outro sentido a partir do Cannaregio à discussão de Somol (1999), o qual distingue as categorias do grid (malha) e da colagem (repetição, justaposição). Atrelando a origem de ambos a Rowe, o grid ao Mathematics of the Ideal Villa e a colagem ao Collage City, Somol (1999) associa o primeiro à autonomia e o segundo à heteronomia. Na primeira fase de Eisenman, sua série de casas, é predominante a malha autônoma; ela é a forma de indexar o projeto, uma notação arquitetônica, regulação geométrica do projeto - mesmo que haja repetição da malha, o deslocamento de sentido é pela ambiguidade de binômios. Será a partir de sua fase das escavaçôes artificiais, com a série de diferentes diagramas do local, das repetiçóes da House XIa, que Eisenman operará a colagem. Como exemplo de colagem, Somol (1999) cita o Wexner Center, projeto da fase das Decomposiçóes que diz não poder ser discutido como "obra", "objeto", "forma" 148 
ou "estrutura", termos da malha reguladora: "Ao contrário, eles apenas parecem ser 'coisas', com toda a informalidade e as possibilidades transformativas do monstruoso e do grotesco que o termo implica." (SOMOL, 1999, p. 17-20, tradução nossa). Retomando o From Object to Relationship II (EISENMAN, 1971), neste Eisenman valoriza a abstração de Malevich sobre a colagem de Leger; talvez no Cannaregio ele tenha invertido.

Esse percurso da Tese à House $X$ apresenta, então, um mergulho na autonomia. O heterônomo, o meio existe na Tese como o ambiente total e retoma apenas nas Decomposiçóes com as diferentes referências. Podemos explorar porque ocorre esse afastamento do meio durante este período. Vimos desde a House I repetição como característica importante no processo de Eisenman. Michael Hays (2009) explora Eisenman, junto a Rosi, Tschumi e Hejduk, como tardomoderno, expoente que vive a nostalgia da cidade moderna. Com a crise do movimento moderno, na década de 1960, esta cidade já não existe, e essa perda geraria um sintoma melancólico. A compulsão pela repetição em Eisenman adquire um sentido de repetição neurótica - como Hays (2009) expõe: uma repetição nostálgica, que procura retomar um estado passado anterior irrecuperável, a cidade moderna (HAYS, 2009, p. 51$52,79,148)$. Hays (2009) não diz neurótico como um diagnóstico, mas, neste sentido, é interessante que Cynthia Davidson sugere que na primeira fase de Eisenman há uma falta de sentido profundo do $\mathrm{Eu}($ self). Tal processo reverte-se quando seus projetos passam a "entrar no solo", a House XIa e o Cannaregio, movimento concomitante ao fato de o arquiteto iniciar psicanálise junguiana em 1978 (DAVIDSON, 2006b, p.26). Deste modo, o mergulho de Eisenman na autonomia formal, neste caso o passo da abstraçáo entre a House I e a House II, bem como o retorno do meio no Cannaregio, apresenta reflexos de questôes internas ao arquiteto, questóes psicológicas. ${ }^{3}$

Retomando Michael Hays e as categorias de Somol (1999), Hays também analisa projeto do Cannaregio a partir do trapeiro de Walter Benjamin (HAYS, 2009, p. 62-69). Próximo ao scaling de Eisenman e da associação de colagem como heteronomia de Somol, o trapeiro recorta objetos do mundo da vida, o destitui de sentido e o cola em novo contexto. Neste caso, Hays diz principalmente do projeto da House XIa colado sobre o projeto de Le Corbusier ao Cannaregio.

Hays (2009) desenvolve suas análises em proximidade ao pensamento de Fredric Jameson. Jameson (1992) identifica a década de 1960 com momento de maiores possibilidades de autonomia à produção cultural, como a arquitetura. O desenvolvimento histórico colocado por Fredric Jameson considera a década de 1960 como momento de derrocada do moderno e eclosão do pós-moderno,

3 Gabriela Izar também pontua Eisenman iniciar psicanálise junto à virada ao fim da série de casas (IZAR, 2015, p. 302). 
consequência do fim de um período do capitalismo e da formulação de um novo. A partir da ideia de infraestrutura e superestrutura, este seria um momento de transição, a reformulação da infraestrutura deixa a superestrutura liberada nesse ínterim:

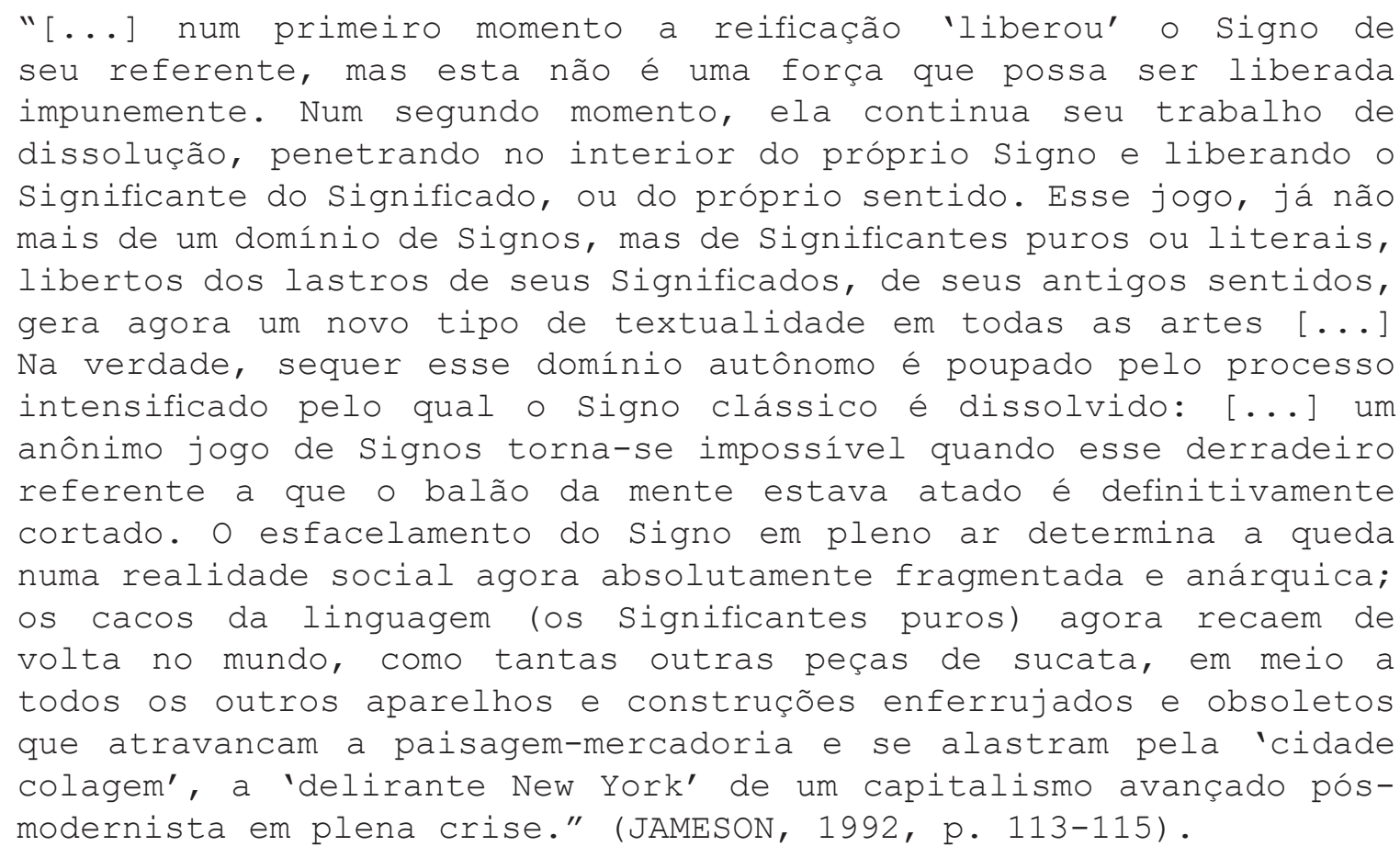

Entre o moderno e o pós-moderno, haveria esse interregno chamado de tardomoderno (late modern), por Jameson, e tardovanguarda (late avant-garde), por Hays, momento de "flutuação do Signo". Jameson identifica a década de 1960 como período marcado por série de mudanças: pela Revolução Cultural Chinesa em 1966, pelo maio de 1968, pelo fim da guerra do Vietnã em 1975 e pela crise do petróleo em 1973, por exemplo; delimitado, portanto, entre 1965 e 1978. A partir deste ponto de vista, o conjunto de casas desenvolvidas por Eisenman, as quais o arquiteto delimita como sua primeira fase, das Transformaçóes, coincide com o período deste interregno de maior possibilidade de autonomia.

O percurso de afastamento e retorno ao meio, operado por Eisenman, sua fase de autonomia pelo processo, trajeto da Tese, 1963, ao Cannaregio, 1978, também coincide com a periodização de Jameson. O ano de 1978 é já início da segunda fase, das escavações, das Decomposiçóes, quando retorna ao que há em volta, mas não igual à totalidade presente na ordem total presente na Tese. Como Hays (2009) coloca, a cidade moderna, a da tradição desde o Renascimento, deixa de operar, o meio não é mais o mesmo, é a cidade do fluxo de informaçôes, "a cidade colagem”, como Jameson coloca em clara referência a Colin Rowe. Coincidentemente é também a partir de 1978 que Eisenman, em sua segunda fase, passa a não defender mais uma continuidade do moderno, mas a superação deste. 
Essa perspectiva permite relacionar o pensamento de Eisenman ao período, a compreendê-lo não como uma produção extemporânea, desterrada, mas imersa nas questôes de seu tempo. Em certo sentido, durante a "flutuação do signo", Eisenman aproveita e o leva a voos altos, tensiona os limites desta possibilidade, mas ao "esfacelar em pleno ar" o arquiteto não abandona sua pesquisa e traz esse repertório formal à nova situação urbana do capitalismo financeiro. Se durante as Transformaçóes discutiu o signo enquanto discutia o projeto moderno, nas Decomposiçóes adquire um caráter político - como exemplo, há o IBA Housing discutindo o muro de Berlim ou, retomando o caminho aberto na introdução, o Memorial aos Judeus Assassinados da Europa. Caráter político reconhecido por autores que o analisam, como Somol (1999, p. 23-24) ou Jecks (1989, p. 265), os quais pontuam a tentativa de Eisenman junto à desconstrução, portanto a partir da sua segunda fase, de se posicionar em favor do feminismo, do semitismo, entre outros grupos oprimidos.

Podemos elencar como a principal característica de Eisenman, algo que balizou qualquer ponto que analisamos, sua proposta de teoria aberta, de instrumentalizar o processo de projeto de maneira menos condicionada possível; vimos diversos exemplos: a dialética massa/superfície progride para positivo/negativo, enquanto a dependência à frontalidade cede quando relaciona a dialética frontal/ oblíquo, a referência à malha como absoluto que se torna a repetição da malha e, por fim, diferentes malhas de referência. Partimos observando Eisenman buscar a ilegibilidade dos projetos, as "palavras esvaziadas de sentido", contudo, podemos afirmar que em nenhum momento eliminou o sentido. Em vez disso, procede deslocando sentidos determinados em busca de outros sentidos, os não determinados, ou seja, procura sentidos outros que podem emergir das relaçóes formais; sentidos não da representação, mas das percepçóes estéticas que as formas proporcionam.

\subsection{Desdobramentos da pesquisa}

É possível, a partir das discussões aqui apresentadas, explorar algumas direções. As análises aqui desenvolvidas sobre a House I contemplam apenas pequena parcela deste projeto, visto que a House I contém questôes que o tempo e escopo deste trabalho não puderam abarcar. Além disso, Eisenman apresenta poucos desenhos desta casa, o aqui exposto amplia a leitura a partir destas referências: os desenhos e texto apresentados pelo arquiteto. Tal como Eisenman estudou ao longo de décadas a Casa del Fascio de Terragni, é possível analisar a House I desenvolvendo desenhos que chegam a detalhes; para tal, é importante retomar o máximo possível os desenhos do projeto, sendo necessário acesso ao acervo do arquiteto no Canadá, no Centro Canadense de Arquitetura (CCA). Também 
por meio do acervo é possível estender a lógica de intercambialidade de questôes e formas de leitura entre os projetos de casa desta série. Um comparativo dos desenhos poderá indicar mais semelhanças entre as quatro primeiras casas, por exemplo, e aprofundar os comparativos aqui apresentados da House I, estendendo-os aos projetos seguintes.

O processo de Eisenman determinar a recepção da House I a partir do texto que a expóe mostra noção ampliada do arquiteto em relação a seus projetos - ele não os dá por acabados, os reitera, permanecem em questão mesmo após o que seria considerado seu término. O processo que utiliza para chegar a uma forma, o processo de um projeto, não é pétreo, neste sentido, a dúvida sustentada sobre a leitura da House I pode ser estendida a outros projetos do arquiteto para compreender suas atuaçóes em outras esferas, como a consagração. Ou seja, é possível reproduzir o mesmo processo de aproximar a House I ao texto que Eisenman desenvolve, neste caso, a Tese The Formal Basis of Modern Architecture (EISENMAN, 2006c), sobre outros projetos; para citar alguns exemplos: a House II pode ser vista junto ao Dall'Oggetto alla Relazionalità (EISENMAN, 1970a) e o Notes on Conceptual Architecture (EISENMAN, 2004b), já a House III a partir do From Object to Relationship II (EISENMAN, 1971) e a questão do oblíquo.

Em outro sentido, o método de análise explicitado pelo arquiteto em sua Tese, e que pudemos utilizar sobre seu projeto da House I, pode ser utilizado em outros contextos, como analisar arquitetura moderna brasileira, incorporando como ferramenta os binômios os quais Eisenman desenvolve, ao longo do estudo das casas, e que tornam o sistema proposto na Tese menos rígido, por exemplo, o binômio frontal e oblíquo. Ademais, é possível estudar o quanto esse método pode elucidar questôes da forma em outros locais. Da mesma maneira que Eisenman fez e encontrou um repertório formal de uma determinada vertente da arquitetura moderna, particularmente Le Corbusier e Terragni, o estudo de sistemas formais de outros contextos poderá encontrar outras abordagens de desenvolvimento formal e talvez encontrar semelhanças entre empenhos discrepantes a partir de outros pontos de vista.

Por fim, é possível estender a proposta desenvolvida aqui para outras fases do trabalho de Eisenman, a fim de acompanhar como dialoga com outras teorias. Esta pesquisa foi focada no início da carreira do arquiteto, particularmente em sua Tese de 1963 e na House I, de 1967, com o intuito de explorar o potencial deste recorte. Com isso, pudemos observar a diferença de compreensão e produção de arquitetura a partir de dois suportes distintos: as bases formais de sua Tese e sua arquitetura conceitual, com o suporte da linguística de Noam Chomsky. É relevante destacar que estender a discussão para outros períodos do trabalho de Eisenman poderá elucidar questôes sobre a 152 
relação da arquitetura com outras disciplinas e sobre a proposta de autonomia de Eisenman, como em relação à desconstrução de Derrida ou às discussóes de Pier Vittorio Aureli acerca da autonomia da arquitetura. Nestes casos, a partir de projetos emblemáticos como o Cannaregio ou o Memorial aos Judeus Assassinados da Europa. Este tipo de estudo permite também explorar o amadurecimento do repertório formal de Eisenman. Vimos que elabora em sua Tese as principais ferramentas, o modo como apreende o espaço. Este instrumental avança para sua fase das Trasnformaçôes e das Decomposiçôes. A partir da década de 1990 ao aproximar-se do conceito de dobra há possível diferença nesse repertório, perceptível na análise de projeto como a Igreja do Ano 2000 em comparação a própria House I, por exemplo. 
Us

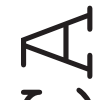

U

$\mapsto$

II

'T

17

0

$\mapsto$

$\stackrel{7}{m}$

U

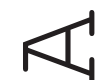

$\mapsto$

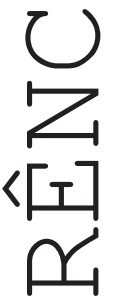

[工]

[I

[I] 
ALLEN, Stan. Trace Elements. In: DAVIDSON, Cynthia (org.) Tracing Eisenman. Nova York: Rizolli International Publications, Inc., 2006, p. 49-65.

ARANTES, Otilia B. F. O lugar da arquitetura depois dos modernos. São Paulo, Edusp, 1993. ARGAN, Giulio C. História da Arte como História da Cidade. São Paulo, Martins Fontes, 2014. AURELI, Pier Vittorio. After Diagrams, in Log, Nova York, n. 6, p.5-9, 2005.

AURELI, Pier Vittorio. Architecture After the Diagram, in Lotus International, Milão, n. 127, p.96-105, 2006.

AURELI, Pier Vittorio; EISENMAN, Peter. A project is a lifelong thing: if you see it, you will only see it at the end. Log, Nova York, n. 28, p.67-78, 2013.

BAUDRILLARD, Jean. Simulacros e Simulaçáo. [S.l.], Relógio D’Água, 1991.

BURGER, Peter. Teoria da Vanguarda. São Paulo. Cosac Naify, 2008.

CHOMSKY, Noam. Language and Mind. Nova York: Harcourt Brace \& World, 1968.

DAVIDSON, Cynthia (org.) Tracing Eisenman. Nova York: Rizolli International Publications, Inc., 2006a.

DAVIDSON, Cynthia. The Absence of the Presence; or, The Void. In: DAVIDSON, Cynthia (org.)

Tracing Eisenman. Nova York: Rizolli International Publications, Inc., 2006b, p. 25-31.

DERRIDA, Jacques. A Certain Impossible Possibility of Saying the Event. Critical Inquiry, Chicago, v. 33, n. 2, p.441-461, jan. 2007.

DERRIDA, Jacques. Khôra. Campinas: Papirus, 1995.

DERRIDA, Jacques. Uma arquitetura onde o desejo pode morar. In: NESBITT, Kate. Uma Nova Agenda Para a Arquitetura: Antologia Teórica 1965-1995. São Paulo: Cosac Naify, 2006. p. 165171.

DERRIDA, Jacques; EISENMAN, Peter. Talking About Writing. ANY: Architecture New York, Nova York, p.18-21, Mai./Jun. 1993.

DERRIDA, Jacques; HANEL, Hilary P. A Letter to Peter Eisenman. Assemblage, [s.l.], n. 12, p.613, ago. 1990.

EISENMAN, Peter. A Arquitetura e o Problema da Figura Retórica. In: NESBITT, Kate (Org.). Uma Nova Agenda Para Arquitetura: Antologia Teórica 1965-1995. Sáo Paulo: Cosac Naify, 2006a. p. 191-198.

EISENMAN, Peter. Aspects of Modernism: Maison Dom-ino and the Self-Referential Sign. Log, Nova York, n. 30, p.139-151, $2014 a$. 
EISENMAN, Peter. Autonomy and the Will to the Critical. Assemblage, [s.1.], n. 41, p.90-91, abr. 2000 .

EISENMAN, Peter. Cardboard Architecture. Casabella, [s.1.], v. 37, n. 374, p.17-31, fev. 1973a.

EISENMAN, Peter. Dall'Oggetto alla Relazionalità: la Casa del Fascio di Terragni. Casabella, [S.1.], n. 344, p.38-41, 1970a.

EISENMAN, Peter. Diagram Diaries. [S.l.]: Universe Publishing, 1999.

EISENMAN, Peter. Diagram: An Original Scene of Writing. Any: Architecture New York, Nova York, p.27-29, 1998.

EISENMAN, Peter. Eisenman Inside Out - Selected Writings 1963-1988. New Haven: Yale University Press, 2004a.

EISENMAN, Peter. Eisenman’s Doubt. Log, Nova York, n. 13/14, p.185-191, 2008 a.

EISENMAN, Peter. Essay by Peter Eisenman. Design Quarterly, Minneapolis, n. 122, p.16-17, 1983.

EISENMAN, Peter et al. Five Architects: Eisenman, Graves, Gwathmey, Hejduk, Meier. [S.1.]: Oxford University Press, 1975.

EISENMAN, Peter. From Object to Relationship II: Casa Giuliani Frigerio: Giuseppe Terragni Casa del Fascio. Perspecta, New Haven, vol. 13/14, p.36-65, 1971.

EISENMAN, Peter. House VI. Progressive Architecture, [S.1.], vol. 6, p.57-67, 1977.

EISENMAN, Peter. House X. [s.l.]: Rizzoli, 1982.

EISENMAN, Peter. Interview with Peter Eisenman: The Last Grand Tourist: Travels with Colin Rowe. Perspecta, New Haven, n. 41, p.130-139, 2008 b.

EISENMAN, Peter. Notes on Conceptual Architecture: Towards a Definition. Design Quarterly, Minneapolis, n. 78/79, p.1-5, 1970 b.

EISENMAN, Peter. Notes on Conceptual Architecture: Towards a Definition. In: EISENMAN, Peter. Eisenman Inside Out - Selected Writings 1963-1988. New Haven: Yale University Press, 2004b. p. 10-27.

EISENMAN, Peter. Notes on Conceptual Architecture II A. In: Environmental Design Research Association, [S.1.], n. 2, 1973b, p. 319-22.

EISENMAN, Peter. O Pós-funcionalismo. In: NESBITT, Kate (Org.). Uma Nova Agenda Para a Arquitetura: Antologia Teórica 1965-1995. São Paulo: Cosac Naify, 2006b. p. 95-100.

EISENMAN, Peter. Post/El Cards: A Reply to Jacques Derrida. Assemblage, [s.1.], n. 12, p.14-17, ago. 1990 . 
EISENMAN, Peter; KOOLHAAS, Rem. Supercrítico. São Paulo: Cosac Naify, 2014b.

EISENMAN, Peter. The End of the Classical: The End of the Beginning, the End of the End. Perspecta, New Haven, n. 21, p.154-173, 1984.

EISENMAN, Peter. There are no Corners After Derrida. Log, Nova York, n. 15, p.111-119, 2009.

EISENMAN, Peter. The Formal Basis of Modern Architecture. Zurich: Lars Müller Publishers, 2006c.

EISENMAN, Peter. Towards an Understanding of Form in Architecture. Architectural Design, [s.l.], p.458-459, out. 1963.

EISENMAN, Peter. Written Into the Void: Selected Writings, 1990-2004. New Haven: Yale University Press, 2007.

EVANS, Robin. Not to be used for wrapping purposes. Peter Eisenman: Fin d'Ou T Hou S. AA Files, Londres, n. 10, p. 68-78, 1985.

FOSTER, Hal. O Complexo Arte-Arquitetura. São Paulo. Ubu Editora, 2017a.

FOSTER, Hal. O Retorno do Real. São Paulo. Ubu Editora, 2017b.

GIDEON, Sigfried. Espaço, tempo e arquitetura. [S.1.], WMF Martins Fontes, 2004.

GUATELLI, Igor. A desconstruçáo em Arquitetura: 1960 ou 1990?. 1999. Dissertação (Mestrado)

- Curso de Arquitetura e Urbanismo, Universidade de São Paulo, São Paulo, 1999.

HAYS, Michael (org.). Architecture Theory Since 1968. Cambridge, Estados Unidos: MIT Press, 1998.

HAYS, Michael. Architecture's Desire: Reading the Late Avant-Garde. Cambridge, Estados Unidos: Mit Press, 2009.

IZAR, Gabriela. Diagramática: descriçáo e criaçáo das formas na arquitetura seriada de Peter Eisenman. Tese (Doutorado) - Curso de Arquitetura e Urbanismo, Universidade de São Paulo, São Paulo, 2015.

JAMESON, Fredric. Periodizando os anos 60. In: HOLLANDA, Heloisa Buarque de (Org.). PósModernismo e Política. Rio de Janeiro: Rocco, 1992. p. 81-126.

JAMESON, Fredric. Pós-Modernismo: a Lógica Cultural do Capitalismo Tardio. São Paulo: Ática, 1997.

JENCKS, Charles. Arquitectura internacional: ultimas tendencias. [S.1.]: Editora Gustavo Gili, 1989.

JOHNSON, Philip; WIGLEY, Mark. Deconstructivist architecture: Catálogo de exposição. [s.l.]: MoMA, 1988. 
KIPNIS, Jeffrey. Introduction: Act Two. In: EISENMAN, Peter. Written Into the Void: Selected Writings, 1990-2004. New Haven: Yale University Press, 2007, p. VI-XXIX.

KIPNIS, Jeffrey; SOMOL, Robert. O Comentário. In: EISENMAN, Peter; KOOLHAAS, Rem. Supercrítico. São Paulo: Cosac Naify, 2014, p. 74-146.

KIPNIS, Jeffrey. Twisting the Separatrix. In: HAYS, Michael (org.). Architecture Theory Since 1968. Cambridge, Estados Unidos: MIT Press, 1998, p. 710-742.

LYNN, Greg. The Talented Mr. Tracer. In: DAVIDSON, Cynthia (org.) Tracing Eisenman. Nova York: Rizolli International Publications, Inc., 2006b, p. 177-195.

MASP. Malhas, Escalas, Rastros e Dobras na Obra de Peter Eisenman: Catálogo de exposição. São Paulo: MASP, 1993.

MONEO, Rafael. Inquietação Teórica e Estratégia Projetual. São Paulo: Cosac Naify, 2008.

MONTANER, Josep Maria. Arquitetura e Crítica. São Paulo: Editora Gustavo Gili, 1999.

MONTANER, Josep Maria. Depois do movimento moderno: Arquitetura da metade do século XX. São Paulo: Editora Gustavo Gili, 2001.

NESBITT, Kate (org.). Uma nova agenda para a arquitetura: antologia teórica, 1965-1995. São Paulo: Cosac Naify, 2006.

PORTO FILHO, Gentil. O fim do objeto: linguagem e experimentaçáo na arquitetura depois do modernismo. 2004. Tese (Doutorado) - Curso de Arquitetura e Urbanismo, Universidade de São Paulo, São Paulo, 2004.

ROWE, Colin; SLUTZKY, Robert. Transparency: Literal and Phenomenal. Perspecta, New Haven, n. 8, p.45-54, 1963.

SCHIAVO, Bruno. Autonomia e Campo Ampliado: Peter Eisenman, Rosalind Krauss e The Institute for Architecture and Urban Studies. 2016. Dissertação (Mestrado) - Curso de Arquitetura e Urbanismo, Universidade de São Paulo, São Paulo, 2016.

SYKES, A. Krista (org.). O campo ampliado da arquitetura: antologia teórica, 1993-2009. São Paulo: Cosac Naify, 2013.

SOMOL, Robert. Dummy Text, or The Diagrammatic Basis of Contemporary Architecture. In: EISENMAN, Peter. Diagram Diaries. [S.1.]: Universe Publishing, 1999, p. 6-25.

SPERLING, David Moreno. Espaço e evento: Consideraçóes Críticas sobre a Arquitetura Contemporânea. 2008. Tese (Doutorado) - Curso de Arquitetura e Urbanismo, Universidade de São Paulo, São Paulo, 2008. 
TELLES, Sophia. Urgência Distraída. In MASP. Malhas, Escalas, Rastros e Dobras na Obra de Peter Eisenman: Catálogo de exposição, São Paulo: MASP, 1993, p. 9-14.

VIDLER, Anthony. Architectural Uncanny. Cambridge, Estados Unidos: MIT Press, 1992.

VIDLER, Anthony. Histories of the Immediate Present: Inventing Architectural Modernism. Cambridge, Estados Unidos: MIT Press, 2008.

YAMAMOTO, João Carlos Amaral. Entre Eisenman, Berlim e o Memorial. 2014. Dissertação (Mestrado) - Curso de Arquitetura e Urbanismo, Universidade de São Paulo, São Paulo, 2014.

WHITING, Sarah. Euphoric Ratio. In: DAVIDSON, Cynthia (org.) Tracing Eisenman. Nova York: Rizolli International Publications, Inc., 2006b, p. 91-111.

WIGLEY, Mark. The Architecture of Deconstruction: Derrida's Haunt. Londres: Mit Press, 1995. ZEVI, Bruno. Saber ver arquitetura. [s.l.], WMF Martins Fontes, 2009.

ZULIANI, Guido. Evidences of Things Unseen. In: DAVIDSON, Cynthia (org.) Tracing Eisenman. Nova York: Rizolli International Publications, Inc., p. 319-348. 